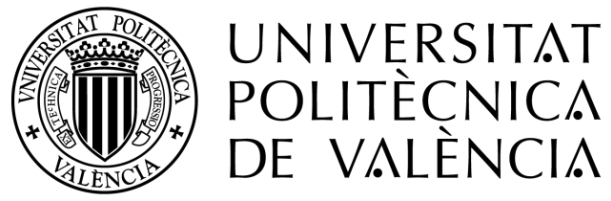

Programa de Doctorado en Ingeniería del Agua y Medioambiental

\title{
Incorporación de las predicciones meteorológicas y climáticas en la planificación y gestión de las sequías. Aplicación a la Cuenca del Júcar
}

\section{Tesis Doctoral}

Doctoranda:

Sara Suárez Almiñana

Directores:

Joaquín Andreu Álvarez

Abel Solera Solera

Valencia, junio 2021 

A mis padres, José y Fina 

"Se mide la inteligencia del individuo por la cantidad de incertidumbres que es capaz de soportar."

Immanuel Kant.

"Olvidamos que el ciclo del agua y el ciclo de la vida son uno mismo".

Jacques Y. Cousteau.

"La mejor manera de predecir el futuro, es crearlo."

Abraham Lincoln. 



\section{Agradecimientos}

Primero me gustaría agradecer a mis tutores Joaquín Andreu y Abel Solera, por confiar en mí y guiarme en este proceso, siempre disponibles y dispuestos a ayudar y compartir su conocimiento en este periplo de proyectos, reuniones, congresos, clases y organización de eventos en el que he aprendido tanto. Siempre amables y comprensivos, igual que Javier Paredes, al que me gustaría agradecer su disposición a ayudar siempre que fuera necesario y sus consejos durante este proceso.

A todos los que han compartido conmigo momentos buenos y no tan buenos, por su ayuda y comprensión, sobre todo a Héctor, mi compañero de vida, siempre optimista y ejemplo de motivación que me recordará este logro toda la vida. A mis compañeros pececillos que puedo llamar amigos, a los cuales espero poder abrazar pronto y continuar con cenas y juegos hasta la madrugada. También a mi familia y amigos de toda la vida que, aunque no supieran qué estoy haciendo, siempre se han interesado y alegrado por mí.

Por último, me gustaría agradecer a mis padres, ya que sin ellos no hubiera podido llegar hasta aquí, ver el orgullo que sienten por mí es la motivación que se necesita para conseguirlo. Gracias a la educación que me han proporcionado, los valores, la exigencia, el apoyo constante e incondicional, los consejos y su actitud en situaciones complicadas, me he convertido en la persona que querría ser. Espero seguir disfrutando de ello durante muchos años y predicar con el ejemplo. 


\section{Resumen}

En las próximas décadas, los fenómenos extremos como las sequías podrían volverse más frecuentes e intensos debido al cambio climático, afectando en gran medida a las cuencas con problemas de escasez hídrica. Por lo tanto, el estudio de estos fenómenos es esencial, así como predecir sus impactos asociados para garantizar una buena gestión de los recursos hídricos disponibles, sobre todo en sistemas de explotación altamente regulados y estresados, que bajo estas circunstancias ven afectadas su fiabilidad y vulnerabilidad.

En esta tesis se aborda esta problemática por medio de un compendio de cinco publicaciones, todas ellas artículos. Dos de estos artículos están publicados en revistas indexadas en el Journal Citation Report (JCR), otros dos están publicados en una revista de reconocido prestigio de habla hispana, y el último se encuentra en proceso de revisión en otra revista indexada en el JCR.

Todos los artículos publicados están relacionados con el desarrollo de una metodología de integración de proyecciones climáticas en la gestión y planificación hidrológica, para ayudar en el proceso de toma de decisiones e intentar prevenir los impactos cuantitativos y cualitativos de futuros eventos de sequía. Por otro lado, el artículo en proceso de revisión se centra en la integración de pronósticos estacionales en la evaluación del riesgo de sequía en tiempo real con la misma finalidad. En ambos casos se lleva a cabo un proceso de evaluación del riesgo de sequía, a medio o largo plazo, mediante una cadena de modelos y procesos de corrección y ajuste al caso de estudio, la cuenca del Júcar. De este proceso se obtiene un 
indicador de riesgo de sequía muy intuitivo que informa sobre la evolución probabilística de los recursos disponibles en el sistema, facilitando así la toma de decisiones a medio o largo plazo.

Los principales resultados asociados a la gestión en tiempo real de la sequía indican que los métodos propuestos son prometedores, ya que todos ellos muestran mejores capacidades de predicción que el método implementado en la actualidad.

Por otro lado, los resultados de cambio climático prevén un futuro complicado para la cuenca de estudio, con reducciones importantes de las aportaciones futuras (sobre todo para finales de siglo) y altas probabilidades de disponer de menores recursos hídricos en el sistema. Lo mismo ocurre al analizar la calidad del agua, ya que se estiman mayores afecciones para horizontes futuros, sobre todo en zonas relacionadas con la actividad agrícola. Sin embargo, existe una gran incertidumbre en estos resultados más allá de mediados de siglo, debido principalmente a la naturaleza variante de las proyecciones climáticas.

A pesar de esta incertidumbre, las metodologías desarrolladas podrían considerarse como el primer paso para tener en cuenta las afecciones de un futuro cambiante en la gestión y planificación hidrológica de forma fiable y robusta, pudiendo implementarse en otras cuencas con la misma problemática y facilitando así la toma de decisiones frente a eventos extremos de sequía. 


\section{Resum}

En les pròximes dècades, els fenòmens extrems com les sequeres podrien tornar-se més freqüents i intensos a causa del canvi climàtic, afectant en gran mesura a les conques amb problemes d'escassesa hídrica. Per tant, l'estudi d'estos fenòmens és essencial, així com predir els seus impactes associats per a garantir una bona gestió dels recursos hídrics disponibles, sobretot en sistemes d'explotació altament regulats i estressats, que davall estes circumstàncies veuen afectades la seua fiabilitat i vulnerabilitat.

En esta tesi s'aborda esta problemàtica per mitjà d'un compendi de cinc publicacions, totes elles articles. Dos d'estos articles estan publicats en revistes indexades en el Journal Citation Report (JCR), altres dos estan publicats en una revista de reconegut prestigi de parla hispana, i l'últim es troba en procés de revisió en una altra revista indexada en el JCR.

Tots els articles publicats estan relacionats amb el desenvolupament d'una metodologia d'integració de projeccions climàtiques en la gestió i planificació hidrològica, per a ajudar en el procés de presa de decisions i intentar previndre els impactes quantitatius $\mathrm{i}$ qualitatius de futurs esdeveniments de sequera. D'altra banda, l'article en procés de revisió es centra en la integració de pronòstics estacionals en l'avaluació del risc de sequera en temps real amb la mateixa finalitat. En ambdós casos es du a terme un procés d'avaluació del risc de sequera, a mig o llarg termini, per mitjà d'una cadena de models i processos de correcció i ajust al cas d'estudi, la conca del Xúquer. D'este procés s'obté un indicador de risc de sequera molt intuïtiu que informa sobre l'evolució probabilística dels 
recursos disponibles en el sistema, facilitant així la presa de decisions a mig o llarg termini.

Els principals resultats associats a la gestió en temps real de la sequera indiquen que els mètodes proposats són prometedors, ja que tots ells mostren millors capacitats de predicció que el mètode implementat en l'actualitat.

D'altra banda, els resultats de canvi climàtic preveuen un futur complicat per a la conca d'estudi, amb reduccions importants de les aportacions futures (sobretot per a finals de segle) i altes probabilitats de disposar de menors recursos hídrics en el sistema. El mateix ocorre al analitzar la qualitat de l'aigua, ja que s'estimen majors afeccions per a horitzons futurs, sobretot en zones relacionades amb l'activitat agrícola. No obstant això, hi ha una gran incertesa en estos resultats més enllà de mitjans de segle, degut principalment a la naturalesa variant de les projeccions climàtiques.

A pesar d'esta incertesa, les metodologies desenvolupades podrien considerar-se com el primer pas per a tindre en compte les afeccions d'un futur canviant en la gestió i planificació hidrològica de forma fiable i robusta, podent implementar-se en altres conques amb la mateixa problemàtica i facilitant així la presa de decisions enfront d'esdeveniments extrems de sequera. 


\section{Abstract}

In the coming decades, extreme events such as droughts could become more frequent and intense due to climate change, greatly affecting basins with water scarcity problems. Therefore, the study of these phenomena is essential, as well as predicting their associated impacts to ensure good management of available water resources, especially in highly regulated and stressed exploitation systems, whose reliability and vulnerability are affected under these circumstances.

This thesis addresses this problem by means of a compendium of five publications, all of them articles. Two of these articles are published in journals indexed in the Journal Citation Report (JCR), other two are published in a prestigious Spanish-language journal, and the last one is under review in another journal indexed in the JCR.

All the published articles are related to the development of a methodology for the integration of climate projections in water planning and management, to help in the decision-making process and try to prevent the quantitative and qualitative impacts of future drought events. On the other hand, the article under revision focuses on the integration of seasonal forecasts in real-time drought risk assessment for the same purpose. In both cases, a drought risk assessment process is carried out, in the medium or long term, by means of a model chain and correction and adjustment processes to the case study, the Júcar River Basin. From this process, a very intuitive drought risk indicator is obtained, providing information on the probabilistic evolution of the resources available in the system and facilitating medium or long-term decision making.

The main results associated with real-time drought management indicate that the proposed methods are promising, as they all show better predictive capabilities than the current method implemented in the basin. 
On the other hand, the climate change results predict a complicated future for the case study, with significant reductions in future inflows (especially by the end of the century) and high probabilities of having lower water resources in the system. The same occurs when analyzing water quality, since greater impacts are estimated for future horizons, especially in areas related to agricultural activity. However, there is great uncertainty in these results beyond mid-century, mainly due to the natural variability of climate projections.

Despite this uncertainty, the methodologies developed could be considered as the first step to take into account the effects of a changing future in hydrological management and planning in a reliable and robust way, and could be implemented in other basins with the same problems, thus facilitating decision making to face extreme drought events. 



\section{Índice}

Agradecimientos ........................................................................................ VII

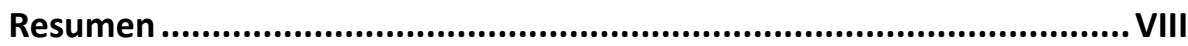

Resum

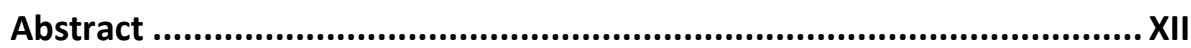

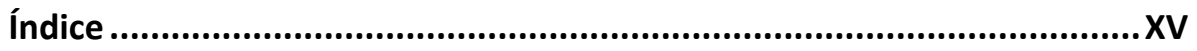

Lista de figuras ......................................................................................... XVII

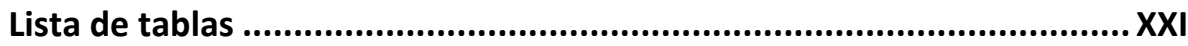

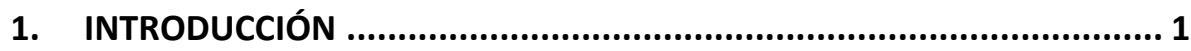

1.1. Motivación y objetivos.....................................................................5

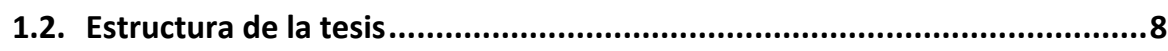

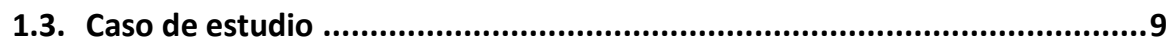

1.3.1. Características generales ........................................................... 10

1.3.2. Práctica actual en la planificación y gestión de los recursos hídricos 17

1.3.3. Uso de proyecciones de cambio climático en la planificación

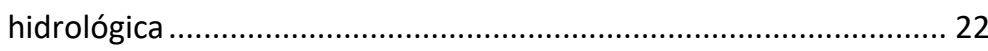

1.3.4. Impactos de las sequías históricas y futuras mejoras....................... 23

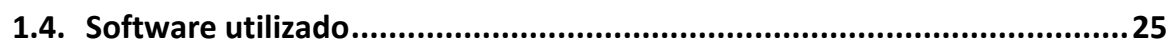

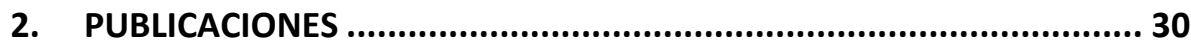

2.1. Ajuste de los datos Pan-Europeos a la escala local para la toma de decisiones relacionadas con los impactos del cambio climático y la escasez hídrica en el marco de la planificación hídrológica ...............................31

2.2. Análisis de la incertidumbre de las proyecciones climáticas en relación a las aportaciones históricas en la Cuenca del Júcar...................................71 
2.3. Evaluación del riesgo en la planificación hidrológica de la cuenca del Júcar bajo la influencia del cambio climático .97

2.4. Efecto del cambio climático en la calidad del agua de la cuenca del Júcar 147

2.5. Otras publicaciones y colaboraciones 186

2.5.1. Artículo en fase de publicación correspondiente a esta tesis 186

2.5.1.1. Integración de pronósticos estacionales en la gestión en tiempo real de las sequías. El caso de la cuenca del Júcar... 187

2.5.2. Otros artículos 233

2.5.3. Participación en congresos nacionales e internacionales 234

2.5.4. Informes públicos del proyecto IMPREX ...................................... 235

3. RESULTADOS Y DISCUSIÓN ...................................................... 239

3.1. Metodología para la integración de proyecciones climáticas.................. 239

3.1.1. Impacto del cambio climático en la calidad del agua ..................... 258

3.2. Metodología para la integración de pronósticos estacionales .................263

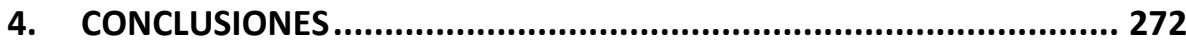

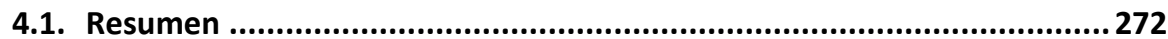

4.2. Principales aportaciones de la tesis ................................................ 274

4.3. Futuras líneas de investigación.................................................... 275

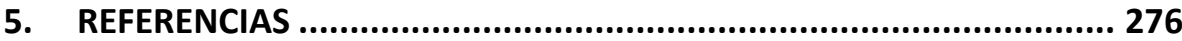




\section{Lista de figuras}

Fig. 1. Localización de la Demarcación Hidrográfica del Júcar en España y sus sistemas de explotación. 10

Fig. 2. Aportaciones de la serie larga 1940-2012 y de la serie corta 1980-2012 en la cuenca del Júcar. 11

Fig. 3. Principales ríos, embalses, aquíferos, zona húmeda y zonas de riego de la cuenca del Júcar. 13

Fig. 4. Masas de agua de la cuenca del Júcar dividida en subcuencas. 15

Fig. 5. Masas de agua de la Cuenca del Júcar impactadas, no evaluadas y no impactadas (CHJ, 2015). 16

Fig. 6. Proceso de evaluación del riesgo implementada actualmente en la cuenca del Júcar. 21

Fig. 7. Esquema simplificado del del SEJ. Modificado de Suárez-Almiñana et al. (2017). 27

Fig. 8. Esquema del SEJ en SIMGES. 28

Fig. 9. Metodología de integración de proyecciones climáticas en la planificación hidrológica. Modificado de Suárez-Almiñana et al., (2017). 32

Fig. 10. Metodología para evaluar el impacto del cambio climático en las aportaciones futuras. Fuente: Suárez-Almiñana et al. (2020a). 72

Fig. 11. Metodología de integración de proyecciones climáticas en la gestión y planificación hidrológica mediante la caracterización de las aportaciones y enfoques determinista y probabilísticos. Modificado de (Suárez-Almiñana et al., 2020b).

Fig. 12. Metodología para estimar la calidad del agua futura teniendo en cuenta el cambio climático. Fuente: Suárez-Almiñana et al., (2021). 148

Fig. 13. Metodología para la inclusión de pronósticos estacionales en la gestión del riesgo de sequía en tiempo real por medio de varias técnicas de generación de caudales y un indicador probabilístico. Modificado de Suárez-Almiñana et al. (In press) 188 
Fig. 14. Comparativa del ensamblado (zona sombreada) de aportaciones climáticas (con y sin regulación) y las aportaciones observadas en el año medio del periodo 1971-2000 en la cuenca del Júcar. 240

Fig. 15. Aportaciones medias anuales de los periodos históricos 1980-2000 (periodo de referencia propuesto), 1971-2000 (periodo de referencia climático), 1980-2012 (serie corta) y 1940-2012 (serie larga). Modificado de SuárezAlmiñana et al. (2020a).

Fig. 16. Izquierda: comparativa entre los datos observados de $\mathrm{P}$ con los datos de origen climático (Media Ens. P) y su corrección del sesgo (Media Ens. P CS). Derecha: comparativa entre las aportaciones observadas y las obtenidas con el modelo HBV-SEJ procedentes de las variables meteorológicas sin corregir (HBVSEJ Media Ens.) y los resultados de calibración de este modelo (HBV-SEJ Spain02). Ambos para el año medio del periodo de referencia 1980-2000 por subcuenca. Modificado de Suárez-Almiñana et al. (2020b). 243

Fig. 17. Estadísticos básicos de las series de aportaciones observadas para la serie larga 1980-2012, la serie corta 1980-2012, y los periodos 1971-2000 y 1980-2000, además de los de las aportaciones del ensamblado 1980-2000 extraídas con el modelo HBV-SEJ.

Fig. 18. Comparativa entre las aportaciones observadas (Apo. Obs.) del periodo de referencia 1980-2000 y los ensamblados extraídos del modelo HBV-SEJ en las opciones A (HBV-SEJ Media Ens. A) y B (HBV-SEJ Media Ens. B), ya corregidos en esta última opción. Modificado de Suárez-Almiñana et al. (2020b). 246

Fig. 19. Media y desviación estándar del periodo de referencia 1980-2000 en la serie observada (Obs. 1980-2000), la serie del ensamblado sin corregir (Ens. 1980-2000) y la del ensamblado corregido en las opciones A (Ens. 1980-2000 A) y B (Ens. 1980-2000 B) 247

Fig. 20. Estadísticos básicos de los ensamblados del periodo de referencia 1980200 y de los horizontes 2020, 2050 y 2080 en ambas opciones metodológicas ( $A$ y B). 248

Fig. 21. Tasa media de cambio d las aportaciones futuras por horizonte (2020, 250 y 2080), opción metodológica ( $\mathrm{A}$ ○ B) y subcuenca, además de para el SEJ teniendo en cuenta ambas opciones. Modificado de Suárez-Almiñana et al. (2020b) 
Fig. 22. Tasa media de cambio (TMC) de las aportaciones futuras (media de opciones $A$ y $B$ ) dependiendo del periodo histórico y el origen de las series con el que se compare. Modificado y actualizado de Suárez-Almiñana et al. (2020a).

Fig. 23. Recursos hídricos almacenados en el conjunto Alarcón-Contreras-Tous durante el periodo futuro 2011-2098, donde se muestra la variabilidad del ensamblado y su media en cada opción metodológica y la media de cada horizonte. Modificado de: Suárez-Almiñana et al. (2020b). 253

Fig. 24. Indicador del riesgo de sequía de la media del ensamblado para los horizontes 2020, 2050 y 2080 en las opciones metodológicas A y B. Modificado de: Suárez-Almiñana et al. (2020b). 254

Fig. 25. Probabilidad de excedencia en septiembre para cada horizonte futuro y opción metodológica. Modificado de: Suárez-Almiñana et al. (2020b). 256

Fig. 26. Número de masas de agua en cada intervalo de incumplimiento por contaminante $\left(\mathrm{DBO}_{5}, \mathrm{P}, \mathrm{NH}_{4}^{+}\right.$y $\left.\mathrm{NO}_{3}{ }^{-}\right)$, simulación (periodo de referencia - $\mathrm{PR}, \mathrm{T}_{\mathrm{a}}$ futura, Apo. Futuras o la combinación de ambas $-\mathrm{T}_{\mathrm{a}}+$ Apo. Futuras) y horizonte futuro (2020, 2050 y 2080). Fuente: Suárez-Almiñana et al., (2021). 259

Fig. 27. Diferencia entre los incumplimientos de los horizontes futuros (2020, 2050 y 2080) y los del periodo de referencia en la simulación de las aportaciones futuras para los $\mathrm{NO}_{3}{ }^{-}$. Modificado de Suárez-Almiñana et al., (2021) 260

Fig. 28. Diferencia entre los incumplimientos del horizonte 2080 y los del periodo de referencia en la simulación de las aportaciones futuras (izquierda) y la de la $\mathrm{T}_{\mathrm{a}}$ y aportaciones futuras (derecha) para el $\mathrm{NH}_{4}{ }^{+}$. Modificado de SuárezAlmiñana et al., (2021). 261

Fig. 29. Indicador del riesgo de sequía para el año normal (2003/2004) considerando varios métodos de generación de series de aportaciones en simulaciones de 7 meses a partir de octubre 2003 y marzo 2004. Modificado de Suárez-Almiñana et al. (In press). 264

Fig. 30. Indicador del riesgo de sequía para el año seco (2005/2006) considerando varios métodos de generación de series de aportaciones en simulaciones de 7 meses a partir de octubre 2005 y marzo 2006. Modificado de Suárez-Almiñana et al. (In press). 267 
Fig. 31. Volúmenes de almacenamiento en el sistema observados y esperados procedentes de varios métodos de generación de series de aportaciones, dentro de los intervalos volumétricos de $0-50 \%$ del total del sistema para las simulaciones de octubre y marzo de los años normal y seco. Modificado de Suárez-Almiñana et al. (In press)...................................................................... 269 


\section{Lista de tablas}

Tabla 1. Descripción, valor y estado de los escenarios contemplados en el IEE.

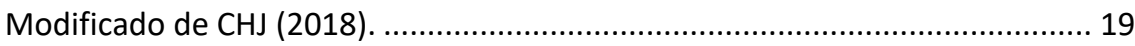

Tabla 2. Miembros del conjunto o ensamblado de las proyecciones climáticas del proyecto SWICCA. Modificado de Suárez-Almiñana et al. (2020b, 2017).... 34

Tabla 3. Valores medios del CRPS por método, año y simulación de los resultados mostrados en la Fig. 31. Modificado de Suárez-Almiñana et al. (In

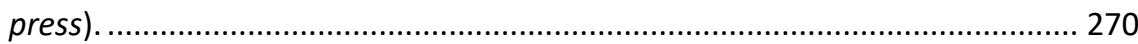





\section{INTRODUCCIÓN}

En las últimas décadas, el cambio climático y sus impactos han adquirido un papel importante en diferentes ámbitos, sobre todo debido a la necesidad de mejorar la adaptabilidad de la sociedad y la capacidad de gestión del riesgo (Hewitt et al., 2013). Este es un fenómeno natural a escala global que se ha acelerado debido principalmente al consumo excesivo de hidrocarburos (IPCC, 2014), lo que aparte de suponer una sobreexplotación de los recursos, también afecta a la contaminación y a la degradación de los ecosistemas (Pellicer-Martínez y Martínez-Paz, 2016).

Uno de los ámbitos más afectados por el cambio climático es el de los recursos hídricos, debido a la alteración del ciclo hidrológico. Por este motivo, existe una gran preocupación en las zonas áridas y semiáridas del planeta, ya que los episodios de sequía y sus impactos socioeconómicos y ambientales podrían ser más recurrentes e intensos según las previsiones de disminución de las precipitaciones y aumento de las temperaturas en determinadas zonas, como en la vertiente mediterránea (Barranco et al., 2018; Hunink et al., 2019; IPCC, 2014), donde se centra este estudio.

La sequía está asociada a un fenómeno natural de precipitación inferior a la media durante un periodo de tiempo determinado, que afecta a los demás componentes del ciclo hidrológico de forma inmediata o con un desfase temporal más o menos extenso (Ortega-Gómez et al., 2018). Esta conexión, también afecta a las necesidades de los ecosistemas y a las actividades humanas, que pueden verse insatisfechas por falta de suministro (Estrela y Vargas, 2012; Palop-Donat et al., 2020).

Estas situaciones excepcionales, exigen la aplicación de herramientas de gestión eficaces tal y como se recoge en la Directiva Marco del Agua (EP, 2000) a nivel europeo. Buenos ejemplos de estas herramientas son los Planes Hidrológicos de Demarcación Hidrográfica (PHDH) y los Planes Especiales de Sequía (PES) (Estrela y Sancho, 2016; Estrela y Vargas, 2012; Ortega-Gómez et al., 2018), ya que tienen en cuenta la sequía 
meteorológica (previamente definida) y su conexión con la sequía hidrológica, operativa y socioeconómica, con el fin de predecir sus impactos con antelación, desde meses o incluso años.

Este estudio está basado en la sequía operativa, entendida como una situación de escasez o déficit en el suministro de agua cuando no se satisfacen las demandas sociales y ambientales de un sistema de recursos hídricos (SRH) (CHJ, 2018, 2015; Ortega-Gómez et al., 2018; Palop-Donat et al., 2020).

De hecho, el principal objetivo de este trabajo es desarrollar metodologías a corto-medio y largo plazo para cubrir todos los periodos de toma de decisiones en base a la escasez del sistema, ya sea en tiempo real o para prevenir impactos a varios años vista, relacionados con el cambio climático. Para ello, como principal resultado se pretende extraer un indicador de escasez del sistema, como aquellos incluidos en los PES (Liu et al., 2017; Palop-Donat et al., 2020; Pedro-Monzonís et al., 2015), cuya finalidad es informar a los gestores de cuenca y a los usuarios finales sobre el estado del SRH en una zona y periodo determinados (Ortega-Gómez et al., 2018). En este proceso, los Sistemas de Soporte a la Decisión (SSD) son esenciales, sobre todo en cuencas altamente reguladas y complejas debido a sus características físicas, legales, socioeconómicas y medioambientales. Teniendo en cuenta estas características, los SSD permiten simular de forma detallada los almacenamientos en embalses y acuíferos, los caudales, el suministro a los usuarios, etc., para ciertos escenarios futuros.

Como caso de estudio, nos fijamos en una de las cuencas complejas de la vertiente mediterránea semiárida, la cuenca del Júcar, que se caracteriza por una elevada variabilidad hidrológica y estar altamente regulada. Esta cuenca hace frente a periodos de sequía recurrentes y plurianuales $y$ presenta problemas de calidad del agua relacionados con nutrientes y materia orgánica. Además, en esta cuenca se dispone de un SSD como herramienta principal de gestión desde hace casi tres décadas, que ha 
resultado ser altamente fiable frente a escenarios hidro-climáticos complicados.

Sin embargo, cada vez existe más incertidumbre sobre estos escenarios futuros debido a la influencia del cambio climático. Ante la falta de previsiones futuras, tradicionalmente se han utilizado series históricas y sus propiedades estadísticas para la predicción de eventos extremos futuros, lo que supone un inconveniente para las aplicaciones reales, siendo poco probable que estas propiedades se repitan en el futuro.

En cambio, actualmente existe una gran variedad de pronósticos estacionales y proyecciones climáticas gracias al desarrollo de los servicios climáticos a nivel global (p.e. CORDEX - Coordinated Regional Climate Downscaling Experiment, https://www.cordex.org/), continental (p.e. SWICCA - Service for Water Indicators in Climate Change Adaptation, http://swicca.eu/) o nacional (p.e. AEMET - Agencia Estatal de Meteorología en España, http://www.aemet.es), donde todos estos datos están disponibles libremente en portales de internet.

Según van den Hurk et al. (2016), los servicios climáticos son esenciales para impulsar la innovación en el sector del agua y aumentar su capacidad de adaptación al cambio climático, por lo que esta gran oferta de datos presenta la oportunidad de desarrollar nuevas herramientas de gestión y planificación hidrológicas, mejorando las actuales mediante la incorporación de estas previsiones con el objetivo de extraer información útil para la toma de decisiones, tanto a corto como a largo plazo.

No obstante, el desarrollo de nuevos métodos no es fácil, especialmente a largo plazo (van den Hurk et al., 2016). Además, existen algunas incógnitas relativas a este tipo de datos, como la forma correcta de manejarlos (Barranco et al., 2018; Collados-Lara et al., 2018; Lemos y Rood, 2010; Marcos-Garcia y Pulido-Velazquez, 2017; Stagl y Hattermann, 2015; Thompson et al., 2017), la forma de acoplar sus escalas espaciales y temporales a el área de estudio (van den Hurk et al., 2018), la reducción de 
la incertidumbre y la necesidad de aplicar procesos de corrección, entre otros.

El uso de los pronósticos meteorológicos estacionales es más común fuera de Europa (Arnal et al., 2018), ya que provienen de una amplia gama de modelos meteorológicos globales y su predictibilidad depende de patrones climáticos a gran escala (p.e. El Niño-Oscilación del Sur - ENSO, la Oscilación del Atlántico Norte - NAO) (Arnal et al., 2018), que pueden no estar relacionados con ciertas áreas de Europa, proporcionando una baja capacidad predictiva.

Este es el caso de la zona mediterránea, donde se han realizado enormes esfuerzos para mejorar la pericia de estos pronósticos en aplicaciones reales mediante técnicas de pos-procesamiento y ajuste de escala de los modelos (Grillakis et al., 2018, 2017; Groot et al., 2019; Hunink et al., 2019; Li et al., 2017; Macian-Sorribes et al., 2020; Madrigal Barrera, 2020). En general, se ha obtenido una capacidad predictiva considerable para los 3 primeros meses, pero esta pericia predictiva varía en función de la estación y la localización (Arnal et al., 2018; Crochemore et al., 2020; Grillakis et al., 2018; Li et al., 2017; Macian-Sorribes et al., 2020; Wanders et al., 2019).

Por otro lado y a pesar de estos avances, los gestores de cuenca no parecen propensos a utilizar los pronósticos y las proyecciones en el proceso de toma de decisiones, debido principalmente a los sesgos de las previsiones, a su calidad e incertidumbre, a los requisitos de posprocesamiento, a la falta de comunicación entre proveedores y usuarios, a su situación económica y a su percepción o tolerancia al riesgo, entre otras razones (Arnal et al., 2016; Crochemore et al., 2016; Lavers et al., 2020; Wanders et al., 2019).

Por lo tanto, para el desarrollo de las metodologías mencionadas anteriormente, se propone la inclusión de los pronósticos estacionales y las proyecciones climáticas en la gestión y planificación hidrológica, aunque es 
necesario resolver todas estas cuestiones para que los gestores de cuenca puedan confiar en ellas. Este es uno de los puntos principales desarrollados en esta tesis, que además relaciona los efectos cuantitativos del cambio climático con los cualitativos, haciendo constar la relación directa entre ambos. Esta relación deriva del grado de autodepuración de las masas de agua, dependiendo de los recursos hídricos de los que disponga y de la temperatura a la que se encuentren, ya que en la mayoría de los casos, la degradación de los contaminantes se ve beneficiada por caudales mayores y temperaturas más elevadas (Rocha et al., 2020; Serpa et al., 2017).

Con este estudio global, se pretende estimar de forma anticipada los impactos derivados de eventos extremos influenciados por el cambio climático, para mejorar la gestión integral de la cuenca y la toma de decisiones, esta vez guiada por una evaluación de impacto más acertada, ya sea a corto o largo plazo. De esta forma se podrían evitar las enormes pérdidas económicas derivadas de los fallos en los suministros por problemas cuantitativos y/o cualitativos, además de los impactos sociales y ambientales asociados.

\subsection{Motivación y objetivos}

La principal inquietud que motiva esta tesis es la evaluación de los pronósticos estacionales y las proyecciones climáticas para obtener pronósticos y proyecciones hidrológicas, estimando los beneficios que podrían aportar en la gestión y planificación hidrológica, ya que en este ámbito no existe un procedimiento robusto y efectivo para utilizar estos datos de forma directa.

La falta de este tipo de procedimientos y su consideración en la toma de decisiones responde a varios factores limitantes relacionados tanto con los pronósticos y proyecciones como con su aprovechamiento actual. A continuación, se introducen algunos de ellos: 
- La incertidumbre inherente a los pronósticos y proyecciones, así como su falta de pericia en ciertas áreas y escalas temporales.

- La importancia de la reducción de escala y la corrección del sesgo de los datos para adaptarlos a las características locales de la cuenca y por lo tanto a la gestión efectiva de recursos.

- La falta de instrumentos de gestión que tengan en cuenta las complejas interacciones entre los sectores y la probabilidad conjunta de que se produzcan fenómenos extremos, junto a los riesgos asociados a los distintos sectores.

- La importancia de comprender mejor las relaciones entre las pautas de la variabilidad climática a gran escala y las tasas y los efectos de fenómenos extremos a nivel regional.

- La falta de un modelo general que evalue de manera fiable los efectos del cambio climático a escala europea, teniendo en cuenta las características de los sistemas de recursos hídricos y de los sectores de consumo que compiten entre sí en cada cuenca.

Por lo tanto, se considera que estos problemas tienen que ser subsanados o amortiguados con el fin de implementar el uso de estos datos en la gestión y planificación de los recursos hídricos de una manera eficaz, robusta y fiable. En principio, todos los órganos que participan en la toma de decisiones se podrían beneficiar de estos datos procedentes de los servicios climáticos. Ejemplo de ello sería la anticipación a las condiciones de sequía, con lo que se podrían adoptar mejores medidas preventivas para reducir sus efectos.

Por todo esto, se pretende ir más allá en este aspecto y presentar esta tesis como un primer paso para solventar todos los problemas y limitaciones mencionados anteriormente. Así, el principal objetivo de esta tesis está relacionado con la determinación de la vulnerabilidad de los recursos hídricos bajo la influencia del cambio climático y el desarrollo de herramientas para predecir el riesgo de sequía a corto-medio y largo plazo, facilitando así la toma de decisiones frente a escenarios extremos. 
Por otro lado, como objetivos parciales podemos mencionar la estimación de los efectos del cambio climático tanto en términos cuantitativos como cualitativos y la influencia que tiene la temperatura del agua en este último caso.

El cometido de las herramientas a desarrollar es la integración de las proyecciones climáticas y los pronósticos estacionales en diferentes cadenas de modelización para detectar con antelación los problemas de escasez hídrica derivados de la ocurrencia de períodos de sequía en el futuro. Por ello, la evaluación del riesgo en función del origen de los datos y su escala temporal es la clave de esta tesis, focalizada en la cuenca del Júcar.

Además, se plantea como objetivo adicional que las metodologías de evaluación de riesgos desarrolladas sean lo suficientemente generales y adaptables como para integrarlas en entornos de desarrollo de SSD y así poder aplicarlos a otras cuencas con la misma problemática de escasez hídrica.

Por lo tanto, los objetivos de esta tesis se centran en la obtención de metodologías eficaces que proporcionen información de utilidad tanto en la gestión como en la planificación hidrológica, cubriendo el corto-medio y largo plazo a partir de pronósticos estacionales y proyecciones climáticas (respectivamente), para evaluar el impacto del cambio climático en la escasez hídrica derivada de periodos de sequía recurrentes y los problemas de calidad del agua asociados.

Esta tesis se desarrolló dentro del Programa de Apoyo para la Investigación y Desarrollo (PAID-01-17) de la Universitat Politècnica de València $y$ en el marco del proyecto europeo IMPREX (IMproving PRedictions and management of hydrological Extremes, H2020 - 641811), con colaboraciones en otros tres proyectos, uno a escala europea y dos a escala nacional. El primero se corresponde con el proyecto SWICCA (Service for Water Indicators in Climate Change Adaptation, C3S_441_Lot1_SMHI) y 
los otros dos a los proyectos ERAS (Estimación del Riesgo Ambiental frente a las Sequias y el cambio climático, CTM2016-77804-P) y RESPHIRA (Reducción de la EScala temporal en la Planificación HIdrológica para la gestión de Recursos y el medio Ambiente, ((PID2019-106322RB-I00) /AEI/10.13039/501100011033).

\subsection{Estructura de la tesis}

La estructura de esta tesis se corresponde con la normativa de tesis por artículos de la Universitat Politècnica de València.

En este apartado introductorio se ha aportado una breve introducción sobre los servicios climáticos y sus peculiaridades, los métodos utilizados actualmente en la gestión y planificación de los recursos hídricos y las principales dificultades que se pueden encontrar a la hora de desarrollar metodologías de integración de proyecciones climáticas o pronósticos estacionales en este ámbito. Además, se ha especificado la motivación y los principales objetivos de esta tesis doctoral.

En el tercer apartado de esta sección, se presenta el caso de estudio, mediante una visión general de sus características climáticas, hidrológicas, físicas y de calidad del agua, acompañadas por prácticas actuales en la planificación y gestión de esta cuenca, el uso de las proyecciones climáticas hasta la fecha e impactos de sequías anteriores que se pretende evitar en un futuro.

Para finalizar este apartado introductorio, se habla sobre el software utilizado. Se trata principalmente de un entorno de desarrollo de SSD que trata de resolver todos los problemas relacionados con los recursos hídricos, complementado con el uso de diferentes softwares estadísticos. 
La segunda sección es la parte más importante de este documento, ya que es dónde se presentan todos los artículos publicados pertenecientes a esta tesis doctoral. Primero se hace un breve resumen de cada uno de ellos y seguidamente se acompaña con la versión de autor. Además, también se hace referencia a otro artículo en fase de publicación y otras publicaciones relacionadas, ya sean artículos, participaciones en congresos nacionales e internacionales o informes del proyecto europeo en el que se desarrolló la tesis.

Seguidamente, en la tercera sección se presentan los resultados más relevantes de esta investigación junto con su discusión, en la que estos se comparan con otros trabajos de referencia y se ponen de manifiesto sus puntos fuertes y debilidades a mejorar.

Por último, en la sección cuarta se presentan las conclusiones y las futuras líneas de investigación.

\subsection{Caso de estudio}

La cuenca del río Júcar fue seleccionada como caso de estudio para esta tesis debido a sus características climáticas, hidrológicas, físicas y de gestión, ya que se trata de un sistema altamente regulado con problemas de escasez hídrica, debido sobre todo a su alta variabilidad hidrológica, lo que da lugar a periodos de sequía recurrentes y multianuales, como los ocurridos en 1981-1986, 1992-1995, 2005-2008 y 2013-2018.

En las siguientes secciones se pude encontrar información más detallada de esta cuenca, así como las prácticas actuales de gestión y planificación hidrológicas e impactos ocasionados por sequias históricas. 


\subsubsection{Características generales}

La cuenca del Júcar se encuentra en el este de España y se corresponde con uno de los 9 sistemas de explotación de la Demarcación Hidrográfica del Júcar (DHJ) (Fig. 1). En realidad, se trata del sistema más importante de esta demarcación debido a su extensión $\left(22.187 \mathrm{~km}^{2}\right)$ y el volumen de recursos generados (1.605 $\mathrm{hm}^{3} / \mathrm{año}$ ) (CHJ, 2015). Este sistema se encuentra en las provincias de Valencia, Albacete, Cuenca y Teruel, por las que fluye el río Júcar de $512 \mathrm{~km}$ de longitud que desemboca en el mar mediterráneo, cuyos principales afluentes son los ríos Cabriel, Albaida y Magro (Fig. 3).
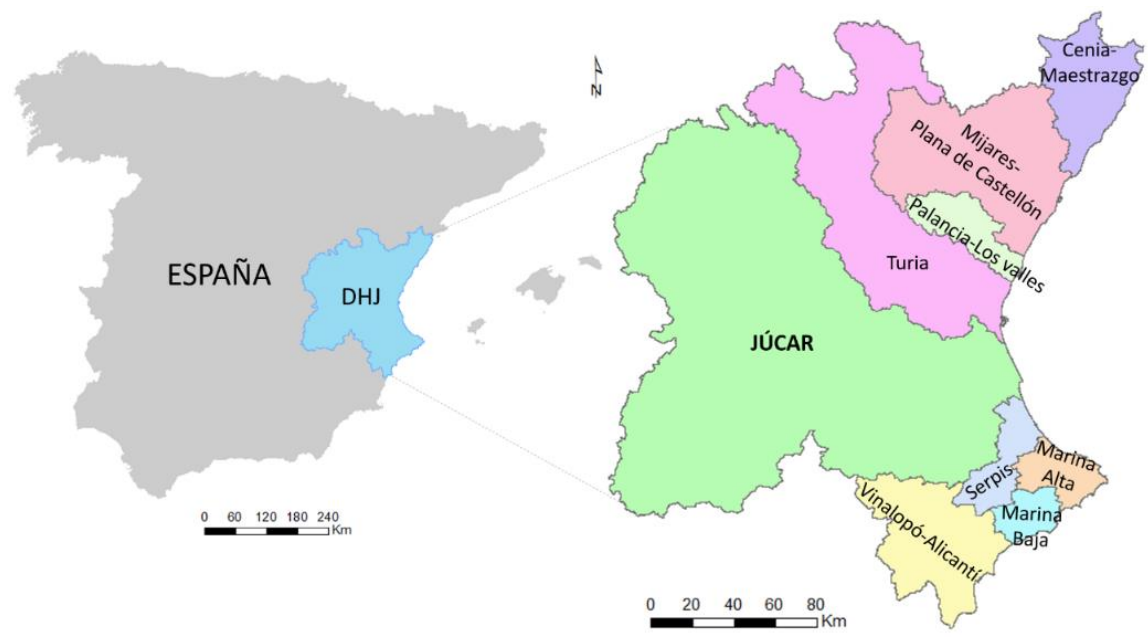

Fig. 1. Localización de la Demarcación Hidrográfica del Júcar en España y sus sistemas de explotación.

Debido a la influencia del clima mediterráneo, la precipitación media (P) de esta cuenca es de 475,2 mm/año, la evapotranspiración potencial media (ETP) de 926,6 mm/año y la temperatura (T) media anual de $14,2{ }^{\circ} \mathrm{C}(\mathrm{CHJ}$, 2015). Sin embargo, durante los meses de octubre y noviembre es bastante frecuente que haya un corto período de lluvias torrenciales debido a embolsamientos de aire frío en altura que choca con el aire caliente de la superficie. Este fenómeno meteorológico comúnmente denominado gota fría o DANA (Depresión Aislada en Niveles Altos) es muy temido debido a la 
intensidad de sus chubascos, provocando inundaciones en cortos periodos de tiempo.

Además, el llamado "Efecto 80" (Hernández Bedolla et al., 2019; PérezMartín et al., 2013) es otra característica hidrológica interesante de la DHJ. Se trata de una disminución significativa de las precipitaciones y aportaciones medias a partir del año 1980, por lo que la Instrucción de Planificación Hidrológica (IPH) (MARM, 2008) se contempló el uso de la serie larga (comenzando en 1940) y la corta (comenzando en 1980) para planificación hidrológica, siendo recomendable el uso de esta última para la gestión actual del sistema. En la Fig. 2 se puede ver claramente este efecto mediante la diferencia entre las aportaciones medias de ambas series temporales en este sistema.

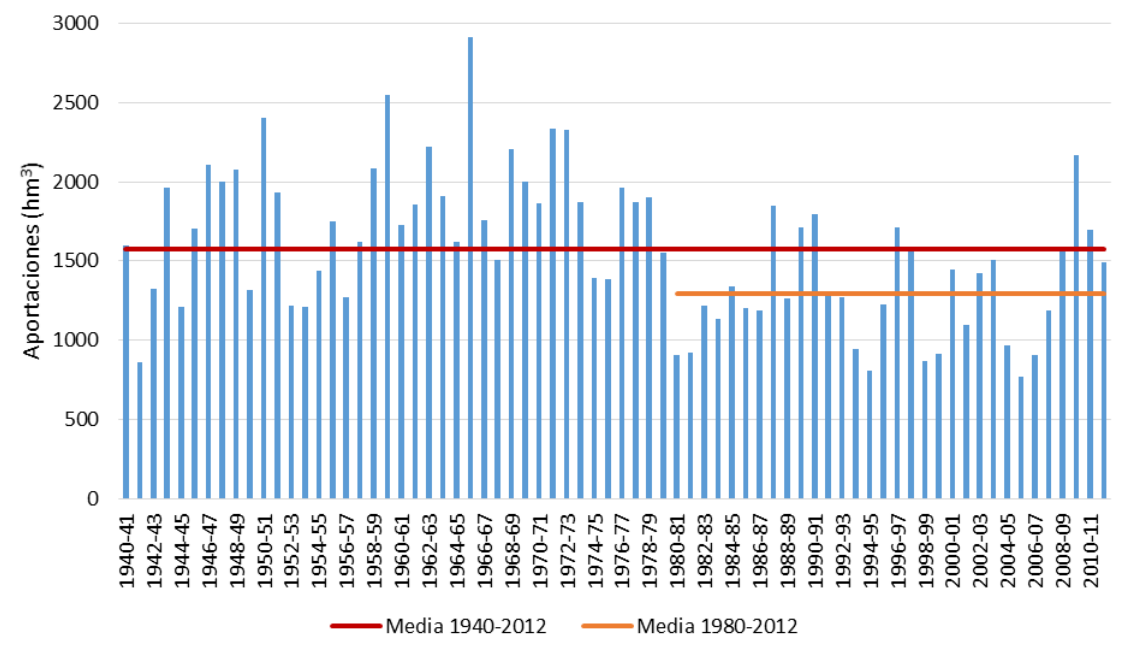

Fig. 2. Aportaciones de la serie larga 1940-2012 y de la serie corta 1980-2012 en la cuenca del Júcar.

Por otro lado, las principales actividades económicas de esta zona son el turismo, la agricultura (principalmente cítricos y hortalizas), la energía hidroeléctrica, la navegación, el comercio y varios sectores industriales (automotriz, muebles, azulejos, etc.). De todas estas actividades, la más demandante en agua es la agricultura de regadío, que representa casi el 
$80 \%$ de la demanda total, mientras que los otros sectores representan el $20 \%$, incluyendo el abastecimiento urbano $(\approx 15 \%)$.

La combinación entre las características hidrológicas y la alta presión de las demandas consuntivas hizo que fueran necesarias diferentes estrategias de gestión para adaptar la cuenca a estos requerimientos. Estas estrategias se componen principalmente de infraestructuras de almacenamiento de agua, el uso conjunto de las aguas superficiales y subterráneas, y los desarrollos institucionales y legales para hacer frente a los períodos de escasez. Así pues, la cuenca del Júcar está altamente regulada y cuenta con varios embalses, los más importantes son el de Alarcón $\left(1.112 \mathrm{hm}^{3}\right.$ ), Contreras $\left(444 \mathrm{hm}^{3}\right)$ y Tous $\left(314 \mathrm{hm}^{3}\right)$. Los dos primeros se encuentran en zonas de cabecera y operan a escala plurianual, mientras que el embalse de Tous se encarga de almacenar las descargas de los embalses de cabecera junto con las aportaciones de la cuenca media para suministrar las demandas de esta zona a escala anual. Además, este embalse también tiene como finalidad evitar inundaciones derivadas de las DANAs, por lo que a finales del año hidrológico se vacía hasta cierto volumen de almacenamiento para prevenirlas.

En la Fig. 3 se puede ver la localización de estos embalses y la división de esta cuenca en cinco subcuencas (Alarcón, Contreras, Molinar, Tous y Sueca), teniendo en cuenta la posición de los embalses y las características hidrológicas de la zona.

Además, la mayor parte de la cuenca está formada por materiales permeables que permiten la infiltración de las precipitaciones a los acuíferos de la Mancha Oriental (parte media de la cuenca, subcuenca de Molinar) y de la Plana de Valencia (cuenca baja, subcuenca de Sueca). Estos acuíferos proporcionan una importante regulación natural, así como un importante volumen de recurso. En la actualidad, una cantidad importante de agua subterránea se extrae de ambos y es destinada principalmente al regadío (Fig. 3) y al abastecimiento urbano. Por otra parte, también estan 
los acuiferos de cabecera, que no se incluyen en la figura ya que a la hora de modelar sus recursos están incluidos en las series de aportaciones.

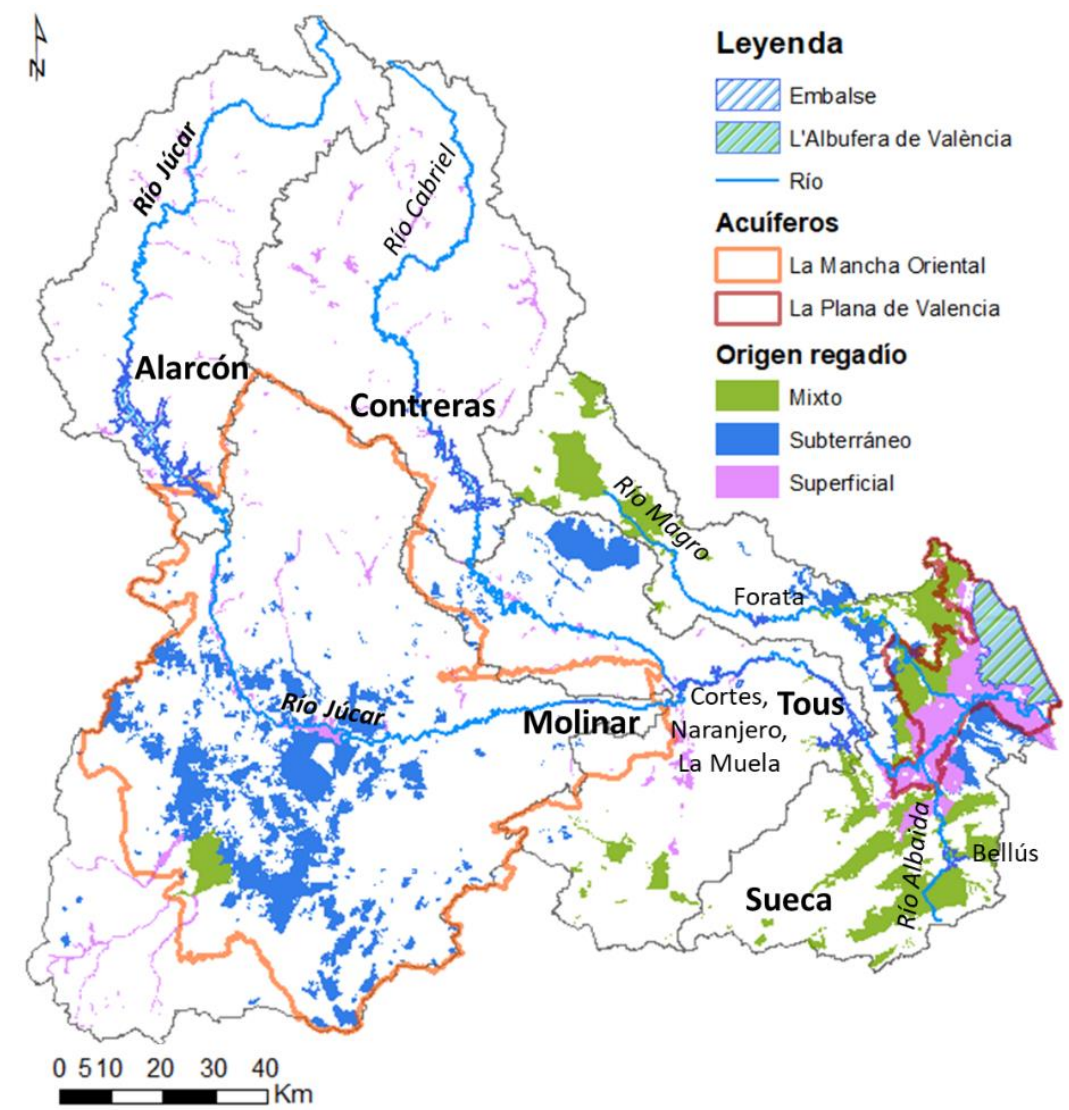

Fig. 3. Principales ríos, embalses, aquíferos, zona húmeda y zonas de riego de la cuenca del Júcar.

La parte interior de la cuenca es una zona montañosa y la cuenca media es una zona relativamente plana (llanura alta) que actualmente soporta la mayor parte de la agricultura de regadío $(\approx 100.000$ ha), fundamentalmente con aguas subterráneas. La cuenca inferior se encuentra en la llanura costera, que soporta las zonas de regadío tradicionales $(\approx 35.000 \mathrm{ha})$ fundamentalmente con aguas superficiales, así como zonas de regadío más 
recientes $(\approx 25.000 \mathrm{ha})$ con origen mixto del agua. Estas zonas de regadío, también llamadas Unidades de Demanda Agrícola (UDA) en los esquemas conceptuales del SRH, están representadas en la Fig. 3 por el origen de los recursos hídricos (mixto, subterráneo y superficial). Si nos fijamos en esta figura, se puede observar cómo las zonas de riego mixtas y procedentes de aguas subterráneas coinciden con la ubicación de los principales acuíferos, mientras que el riego superficial se restringe en su mayor parte a la subcuenca de Sueca, aguas abajo del embalse de Tous. Además, los humedales también son comunes en esta zona, en la Fig. 3 se puede observar el más importante, localizado en la zona costera y llamado I'Albufera de Valencia, con un área de 21.120 ha que incluye un lago y una gran extensión de cultivos de arroz a su alrededor.

También es importante destacar que la reutilización directa de las aguas residuales recuperadas es una fuente no convencional de agua que puede proporcionar hasta $18,3 \mathrm{hm}^{3}$ (CHJ, 2015) en la cuenca inferior. Su uso integrado, junto con las aguas superficiales y subterráneas, aumenta la fiabilidad y la resiliencia, reduciendo así la vulnerabilidad en tiempos de sequía.

Otro aspecto primordial de esta cuenca es el estado cualitativo de sus 140 masas de agua (Fig. 4), en las que se hacen mediciones periódicas y se evalúa su estado teniendo en cuenta la concentración de algunos contaminantes relacionados con aportes de materia orgánica y nutrientes, además de su dispersión química o biológica. Los principales contaminantes considerados son: la Demanda Bilógica de Oxígeno al quinto día $\left(\mathrm{DBO}_{5}\right)$, el fósforo (P), el amonio $\left(\mathrm{NH}_{4}^{+}\right)$y los nitratos $\left(\mathrm{NO}_{3}{ }^{-}\right)$. 


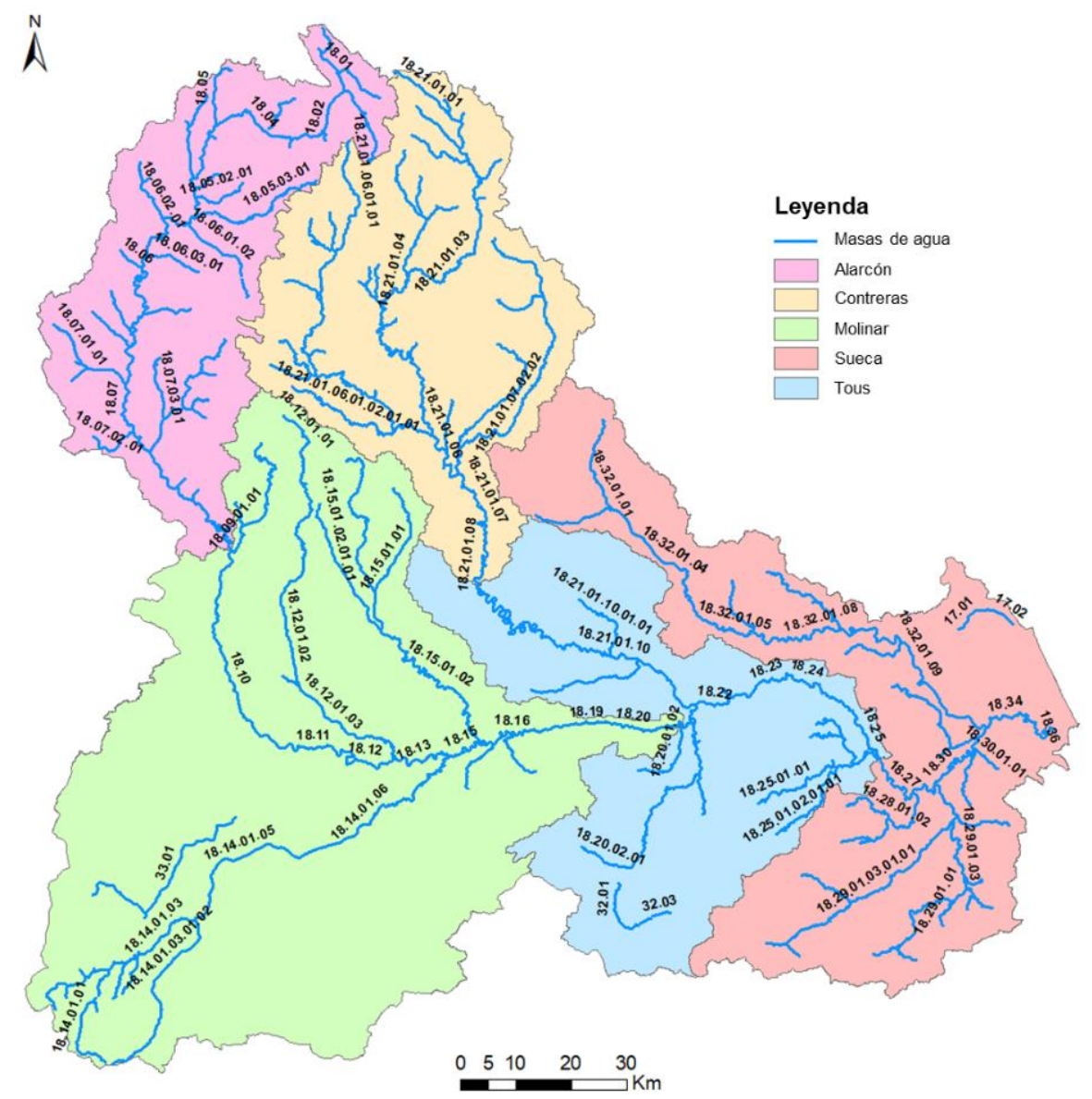

Fig. 4. Masas de agua de la cuenca del Júcar dividida en subcuencas.

En la Fig. 5 se pueden ver las masas de agua impactadas, las no impactadas y las no evaluadas para cada contaminante. Entre todas ellas, se distingue un número considerable de masas de agua no evaluadas (39), ya sea por problemas de inaccesibilidad, falta de fondos, que no se considerara necesario $u$ otras razones. De las masas restantes (101), 12 de ellas se encuentran impactadas por $\mathrm{NO}_{3}{ }^{-}, 8$ por $\mathrm{P}, 5$ por $\mathrm{NH}_{4}^{+}$y 4 por $\mathrm{DBO}_{5}$. Este impacto está relacionado con concentraciones elevadas, superiores a los umbrales establecidos en el Real Decreto 815/2015 (BOE, 2015). 


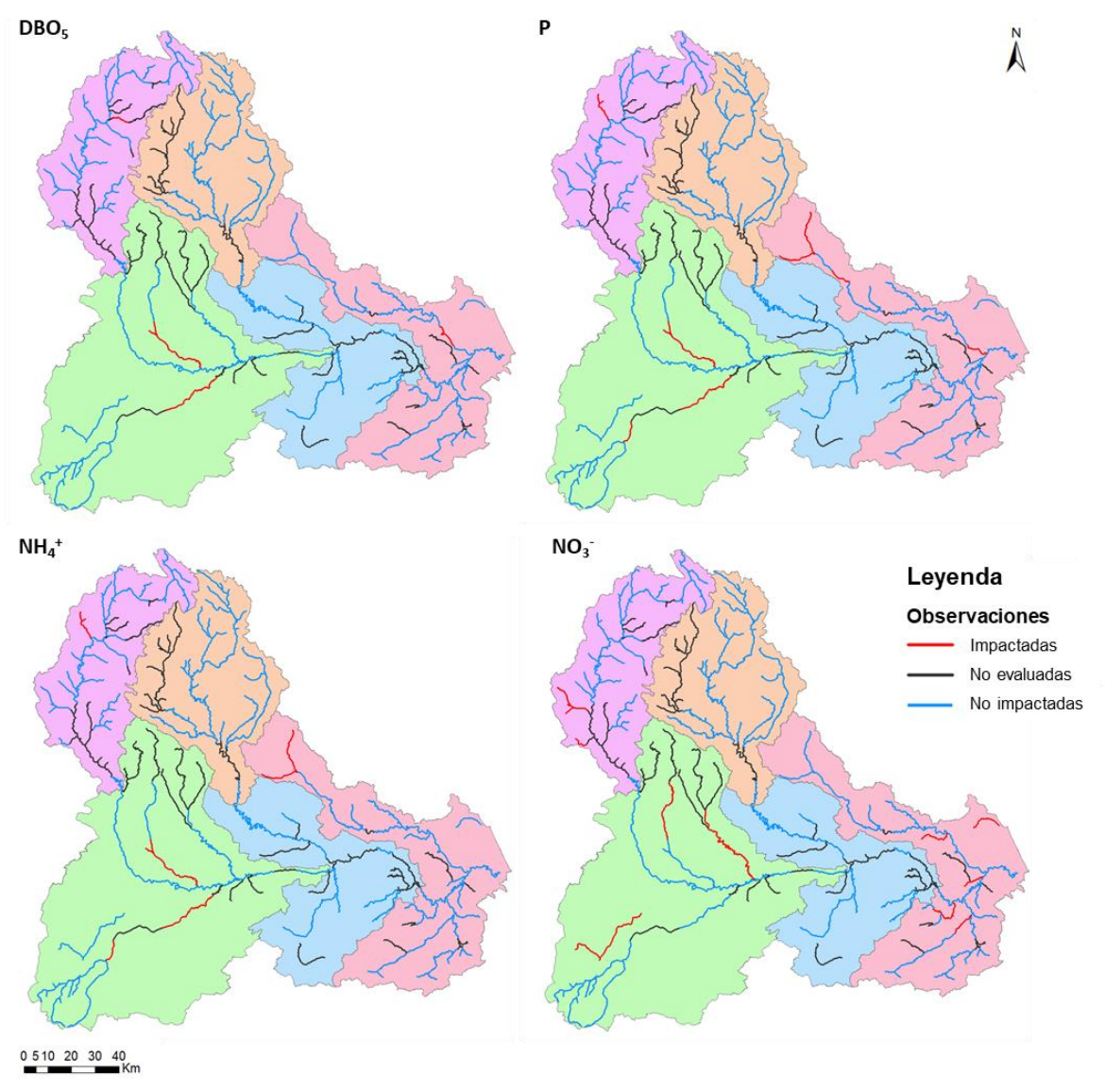

Fig. 5. Masas de agua de la Cuenca del Júcar impactadas, no evaluadas y no impactadas (CHJ, 2015).

En general, las subcuencas más afectadas por todos los contaminantes son las de Molinar y la de Sueca, sobre todo en el caso de los $\mathrm{NO}_{3}{ }^{-}$en este último caso, coincidiendo con las zonas de mayor presión agrícola (Fig. 3). 


\subsubsection{Práctica actual en la planificación y gestión de los recursos hídricos}

Además de las infraestructuras y las estrategias de gestión, los avances institucionales y jurídicos de las últimas décadas han sido bastante significativos, ya que el estrés hídrico de este SRH es elevado. La relación entre las demandas y los recursos hídricos es aproximadamente del 90\%, lo que significa un fuerte estrés hídrico y escasez que conduce a la sobreexplotación de los recursos en los periodos más críticos.

La Confederación Hidrográfica del Júcar (CHJ) es la institución encargada de la gestión del agua en la DHJ y la responsable de la elaboración del Plan Hidrológico de la Demarcación Hidrográfica del Júcar (PHDHJ) (CHJ, 2015) y del Plan Especial de Sequías (PES) (CHJ, 2018). Esta institución gestiona los recursos hídricos desde 1936 y los distribuye entre los sectores urbano, agrícola, hidroeléctrico e industrial, teniendo en cuenta la protección del medio ambiente y los derechos y prioridades de agua predefinidos. Las decisiones de asignación de agua se toman en diferentes espacios de tiempo y bajo diferentes escenarios.

A largo plazo, la asignación del recurso se realiza en el marco del PHDHJ, diseñado por la CHJ desde 1998, y actualizado regularmente cada 6 años (última actualización en 2015). De hecho, como se ha comentado anteriormente, la última versión del PHDHJ se basa en la serie corta 19802012 a la hora de gestionar los recursos hídricos del sistema, de este modo se tiene una buena representación de las características hidrológicas actuales de la cuenca al tener en cuenta el efecto 80. Sin embargo, también se realizan y se tienen en cuenta simulaciones con la serie larga 1940-2012, como fue establecido en la IPH. Además, a corto y medio plazo, la asignación de agua se decide en las Juntas de Explotación de cada sistema de explotación de la $\mathrm{DHJ}$, teniendo en cuenta la situación real de almacenamiento de embalses y acuíferos. 
En más detalle, a largo plazo podemos diferenciar entre la planificación para la reducción de la vulnerabilidad y, por otra parte, la planificación de las sequías. La primera es la nombrada anteriormente, realizada por la $\mathrm{CHJ}$ para actualizar el PHDHJ, que incluye la modelización hidrológica y la asignación de recursos mediante escenarios hidrológicos con la ayuda de SSD (Andreu et al., 2009). Estos escenarios se basan principalmente en la hidrología del pasado, utilizando aportaciones en régimen natural. También, mediante los SSD se pueden obtener indicadores de vulnerabilidad para cada usuario, pero deben cumplir con un criterio acordado para considerar que la vulnerabilidad a la sequía está dentro de los valores aceptables, de modo que el PHDHJ sea factible y sostenible.

De la misma forma, se introdujo un enfoque claramente proactivo en esta demarcación, así como en todas las cuencas españolas desde el año 2000, mediante el desarrollo del PES, que fue aprobado en 2007 en la DHJ (Estrela y Vargas, 2012). La segunda versión de este plan incluye la vigilancia de la sequía mediante un doble sistema de indicadores para definir los escenarios de sequía: el Indicador de Estado de Sequía prolongada (IES) y el Indicador de Estado de Escasez (IEE) (CHJ, 2018).

El IES tiene que ver con la falta de precipitaciones durante un periodo de tiempo y tiene en cuenta aspectos como la intensidad y la duración. El objetivo de este indicador es identificar la reducción de precipitaciones y la escorrentía por causas naturales, en un tiempo y ubicación determinados, independientemente de la gestión de los recursos hídricos (CHJ, 2018). Sin embargo, el IEE está relacionado con los recursos hídricos disponibles para satisfacer las demandas y su objetivo es reflejar la capacidad de atender las demandas en situaciones de reducida disponibilidad hídrica y, a la vez, servir como instrumento de ayuda en la toma de decisiones relativas a la gestión de los recursos hídricos en esas situaciones (CHJ, 2018).

Los escenarios derivados del IEE, que arrojan resultados entre 0 y 1 (valor óptimo), se dividen en normalidad, prealerta, alerta y emergencia 
(Tabla 1), que al mismo tiempo están relacionados con un conjunto específico de medidas.

Tabla 1. Descripción, valor y estado de los escenarios contemplados en el IEE. Modificado de CHJ (2018).

\begin{tabular}{c|c|c} 
Valor IEE & Estado & Descripción \\
\hline $1,00-0,50$ & Normalidad & Ausencia de escasez \\
\hline $0,50-0,30$ & Prealerta & Escasez moderada \\
\hline $0,30-0,15$ & Alerta & Escasez severa \\
\hline $0,15-0,00$ & Emergencia & Escasez grave \\
\hline
\end{tabular}

Estas medidas incluyen mejoras en la eficiencia de los usos del agua, prácticas de ahorro de agua, reutilización directa de aguas residuales recuperadas, uso conjunto de aguas superficiales y subterráneas, compra de derechos de agua para la protección del medio ambiente, mejoras en los controles de los usos del agua, la calidad del agua y el estado ecológico de las masas de agua, y revisión de las acciones y análisis posteriores a un episodio de sequía, entre otros. Además, los informes de seguimiento de estos indicadores se actualizan mensualmente y están disponibles en la web de la $\mathrm{CHJ}$ (www.chj.es). Estos informes sirven como un sistema de alerta temprana para activar las medidas de anticipación y mitigación asociadas a cada escenario, con el fin de disminuir la vulnerabilidad y aumentar la resistencia del sistema.

El IEE y las medidas asociadas a cada escenario de sequía también se han diseñado mediante simulaciones del funcionamiento del sistema utilizando escenarios hidro-meteorológicos basados en valores históricos.

Este sistema de vigilancia de la sequía es útil para la alerta temprana y las medidas contra la sequía. Sin embargo, para gestionar las sequías se 
necesita un sistema de información más elaborado y detallado que permita evaluar mejor el riesgo y la eficacia de las medidas que pueden utilizarse para modificar los riesgos y mitigar sus efectos, tanto en los diferentes usos establecidos como en el medio ambiente.

Este es el caso de la gestión de la sequía a corto o medio plazo, en tiempo real durante los escenarios de alerta y emergencia. En este último caso, las decisiones de asignación de agua se toman en las sesiones del Comité Permanente de Sequías, teniendo en cuenta la situación hidrológica y meteorológica real, así como las directrices sobre medidas de mitigación incluidas en el PES para encontrar una asignación equitativa entre los usuarios minimizando los impactos ambientales.

Para el diseño final de las medidas que se aplicarán en tiempo real, se realiza una evaluación probabilística de los riesgos utilizando previsiones hidrológicas para un tiempo de anticipación de entre 12 a 24 meses con la ayuda de los SSD. Mediante esta simulación basada en los caudales previos, se evalúan las probabilidades de déficits en demandas y requerimientos ambientales y de estado del sistema.

Además, la evaluación de los riesgos y la eficacia de las medidas seleccionadas para mitigar los efectos de la sequía en todos los ámbitos también se realiza mediante nuevas simulaciones del SSD, como se puede observar en la Fig. 6.

Actualmente, las múltiples series de aportaciones requeridas para esta metodología de evaluación de riesgos se obtienen mediante un modelo multivariado aurorregresivo de media móvil (ARMA) (Box et al., 2016; Salas et al., 1980). Con este tipo de modelización, las series generadas respetan, no sólo los estadísticos básicos de los valores históricos de las aportaciones, sino también las características históricas de la sequía. 


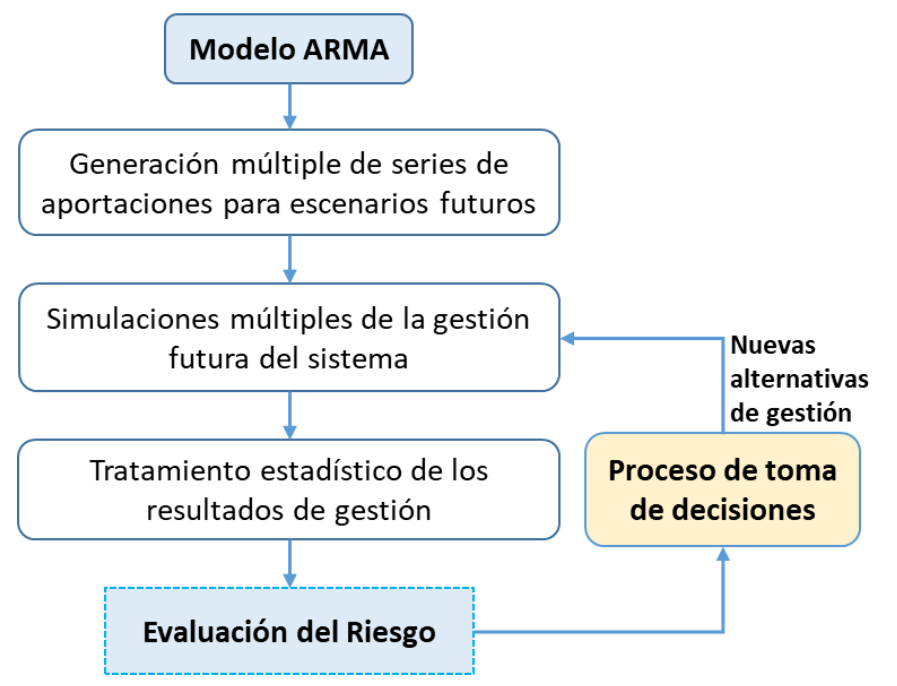

Fig. 6. Proceso de evaluación del riesgo implementada actualmente en la cuenca del Júcar.

Después de simular la gestión futura del sistema para cada una de las series generada y el tratamiento estadístico de sus resultados, se evalúa el riesgo de sequía. En este sentido, si los riesgos estimados son aceptablemente bajos, no es necesario adoptar medidas. Sin embargo, si los riesgos se consideran inaceptablemente altos, entonces deben aplicarse algunas medidas. En ese caso, se formulan alternativas con conjuntos de medidas integrándolas en el SSD para evaluar la modificación de los riesgos y la eficiencia de las medidas. Este proceso iterativo puede continuar hasta que, finalmente, se alcance un valor de riesgo aceptable y el proceso termine. Este enfoque proporciona una visión completa de las consecuencias de la toma de decisiones, ya sea en lo que respecta a la gestión o a las infraestructuras (Andreu et al., 2013). 


\subsubsection{Uso de proyecciones de cambio climático en la planificación hidrológica}

En la actualidad, las proyecciones climáticas no se han incorporado explícitamente en el análisis realizado con la ayuda de los SSD para la última versión del PHDHJ (CHJ, 2015). Los efectos del cambio climático se evaluaron reduciendo las aportaciones en régimen natural en un cierto porcentaje para los futuros ciclos hidrológicos de gestión (6 a 18 años).

En este caso, en el PHDHJ (CHJ, 2015) se aplicó un coeficiente de reducción global del $12 \%$ a las aportaciones de la $\mathrm{DHJ}$, basado en los resultados obtenidos en el estudio del CEDEX (2010) sobre la evaluación de los efectos del Cambio Climático en los recursos hídricos, en el que utilizaron los escenarios climáticos generados por la Agencia Estatal de Meteorología (AEMET) procedentes del 40 informe (AR4) de evaluación del cambio climático (IPCC, 2007).

Por otro lado, más recientemente, las proyecciones climáticas procedentes del 50 informe de evaluación (AR5) (IPCC, 2014), procesadas por AEMET, fueron consideradas en el informe del CEDEX (2017), donde se extrajeron tasas de cambio de las variables meteorológicas e hidrológicas para las principales cuencas españolas. Para esta demarcación, se estimó la futura disminución de los recursos hídricos y el aumento del número de sequías y su intensidad, pero estos resultados todavía no han sido integrados en los planes de cuenca ni utilizados en la toma de decisiones, aunque sí se hace mención a ellos en el PES (CHJ, 2018).

Sin embargo, es importante señalar que esto no es debido a falta de datos, estudios o experiencia, se trata más bien de la incertidumbre asociada a estos datos, que en la mayoría de casos supera a la de las herramientas de gestión actuales. Por lo que, si este aspecto de los datos no mejora, sólo se introduciría una nueva fuente de incertidumbre en las metodologías actualmente utilizadas para la planificación y gestión de la 
sequía en la DHJ y podría no ser de utilidad para los usuarios finales a los que va dirigida.

Por lo tanto, parece que una mejora en este sentido sería necesaria para ajustar la asignación de agua en los futuros planes hidrológicos y obtener una evaluación más fiable de la vulnerabilidad del sistema frente a sequías futuras.

\subsubsection{Impactos de las sequías históricas y futuras mejoras}

En el informe post-sequia de 2005-2008 (CHJ, 2010) se comentan los principales impactos ambientales y socio-económicos ocasionados en las sequias de los periodos 1992-1995 y 2005-2008, así como la efectividad de las medidas implementadas en el segundo caso.

El desarrollo del primer PES (CHJ, 2007) coincidió con el periodo de sequía 2005-2008, dando lugar a que las medidas que se iban proponiendo para cada escenario fueran testadas al mismo tiempo. Esto supuso un gran éxito en la gestión de este periodo, creando un claro precedente para sequias futuras, ya que sus impactos (considerables) fueron mucho menores que los acontecidos en el periodo 1992-1995, cuando se carecía de este tipo de planes, a pesar de tratarse de una sequía más intensa.

En el período de sequía 1992-1995 se produjeron importantes impactos en la agricultura (restricciones en el suministro de agua, pérdida de cultivos anuales y daños permanentes), la calidad del agua (deterioro de las aguas superficiales y subterráneas, eutrofización, aumento de las cargas de contaminación y salinidad), las hidroeléctricas (reducción de la producción) y el medio ambiente (aumento de la mortalidad de las especies acuáticas, pérdida de la biodiversidad, deterioro de los humedales). Además, durante los dos meses de verano de 1994 y 1995, se secó un tramo de casi 30 km del río Júcar en la llanura de Albacete. 
Sin embargo, en el episodio de sequía de 2005-2008, la mayoría de estos impactos tuvieron sólo una importancia marginal. En la agricultura de regadío se experimentaron restricciones, pero sólo se produjeron reducciones menores de los rendimientos, aunque en muchas zonas el riego era más complicado (por ejemplo, a turnos) y el agua fue más cara.

Respecto a la calidad del agua y del medio ambiente, los impactos tuvieron menor importancia, aunque hubo cierta mortalidad de especies acuáticas (incluidas especies en peligro/protegidas) y mayor concentración de especies cerca de la superficie del agua. Además, l'Albufera de Valencia no experimentó ningún deterioro adicional.

Por otra parte, se redujo la generación de energía hidroeléctrica $(40 \%$ con respecto a años anteriores) y los rendimientos de la agricultura de secano.

También, hay que destacar que la gestión de la sequía en este periodo permitió mantener el tramo de la cuenca del río Júcar en la llanura de Albacete con agua fluyente. Pero, aun así, el impacto económico fue importante, con inversiones en medidas de emergencia cuantificadas en más de 75 millones de euros.

La experiencia de la gestión de la sequía de 2005-2008 demostró la importancia de la planificación y la gestión proactiva de la sequía para hacer frente a las sequías extremas. Sin embargo, a fin de mejorar aún más la capacidad de recuperación y disminuir la vulnerabilidad frente a las sequías en el sistema de explotación Júcar, sería conveniente introducir las siguientes mejoras para reducir la incertidumbre asociada al método utilizado actualmente en la gestión de la sequía:

- Proyecciones fiables de cambio climático para variables meteorológicas ( $\mathrm{P}$ y $\mathrm{T}$ ) e hidrológicas (caudales) que permitan un mejor ajuste de la asignación de agua en el PHDHJ y de los índices de sequía y las medidas asociadas consideradas en el PES. 
- Pronósticos estacionales fiables de P, T y caudales para la gestión de la sequía en tiempo real. Estos pronósticos podrían incorporarse en la evaluación de los impactos probabilísticos en tiempo real, reduciendo la incertidumbre en el pronóstico de los impactos probabilísticos que se utilizan para la toma de decisiones en el diseño y aprobación de los planes de acción estacionales y las medidas de mitigación. Además, estas previsiones podrían ayudar a los agricultores a diseñar su selección de cultivos y sus estrategias de riego para cada temporada de riego, entre otros servicios públicos dirigidos a otros sectores.

\subsection{Software utilizado}

El principal software utilizado en este estudio fue un SSD en continuo desarrollo llamado AQUATOOL (Andreu et al., 2009, 1996), que permite analizar los problemas asociados a la gestión y planificación de los recursos hídricos en cuencas complejas mediante sus diferentes módulos asociados.

Este programa es ampliamente utilizado a nivel nacional e internacional, ya que se emplea en el diseño de los Planes Hidrológicos de Cuenca españoles y en muchas otras cuencas del extranjero (Latinoamérica y Turquía entre otros). Una de las razones principales de este uso extendido podría ser su interfaz de usuario amigable y facil de manejar, ya que se accede a ella por uno de sus módulos, donde se puede diseñar el esquema conceptual del sistema de explotación con todos sus elementos principales, que además está conectada con los demás módulos y sus resultados. Esta es una característica muy importante desde el punto de vista de este trabajo, ya que está basado en una cadena de modelos en la que se necesita que los resultados de un modelo sean a la vez los datos de entrada de otros modelos. Por lo tanto, esta interconexión entre módulos es una gran ventaja en este ámbito. 
Los módulos empleados en este estudio fueron EVALHID (ParedesArquiola et al., 2012), SIMGES (Andreu et al., 2007), MASHWIN (OchoaRivera, 2008, 2002), SIMRISK (Haro-Monteagudo, 2014; Haro-Monteagudo et al., 2017; Sánchez-Quispe et al., 2001) y RREA (Paredes-Arquiola, 2021), que fueron utilizados para construir el modelo hidrológico, el de gestión o asignación de agua, el estocástico, el de evaluación del riesgo y el de calidad del agua a gran escala, respectivamente. Todos ellos se describen a continuación.

EVALHID (EVALuación de los recursos HíDricos) permite el desarrollo de modelos hidrológicos en cuencas complejas para evaluar la cantidad de recursos hídricos generados en cada una de ellas. En este módulo se encuentran integrados varios modelos de precipitación-escorrentía, todos ellos del tipo agregado con aplicación semi-distribuida. Estos modelos tienen que elegirse en función de los datos disponibles, la complejidad de la cuenca y la experiencia de los usuarios en su elaboración y calibración.

SIMGES (SIMulación de GEStión de cuencas) se utiliza para simular la gestión del sistema de explotación y la asignación de recursos resultante. Desde este módulo se puede acceder a todos los demás, ya que se trata de la interfaz de inicio del programa, donde se puede dibujar un esquema del sistema de explotación y aportar todos los datos referentes a cada uno de los elementos que lo conforman (como embalses, aportaciones, demandas, retornos, acuíferos, canales, caudales ecológicos, etc.), además de las reglas de operación y los derechos y prioridades de uso de los recursos hídricos de la cuenca. La asignación de agua se efectúa mediante un algoritmo de optimización que abarca un solo período de tiempo (un mes, en este caso de estudio), y que minimiza los déficits y maximiza la adaptación a las curvas de volumen objetivo de los embalses, teniendo en cuenta las prioridades establecidas en el sistema.

La Fig. 7 muestra los elementos principales del Sistema de Explotación del Júcar (SEJ) de forma ligeramente simplificada, que fueron incluidos en el modelo SIMGES (Fig. 8). Este modelo, empleado actualmente por la $\mathrm{CHJ}$, 
fue calibrado y validado con datos observados, permitiendo integrar medidas y evaluar el resultado final, además de la posibilidad de ser nuevamente calibrado si los datos de entrada cambian o se actualizan, como ocurre en cada ciclo de planificación.

Por lo tanto, en la Fig. 7 se observan todos los elementos que desempeñan un papel importante en la gestión de los recursos hídricos en esta cuenca y que ya se han comentado en el apartado 1.3.1. del caso de estudio. Sin embargo, aquí se concretan las principales demandas urbanas y de riego, y los acuíferos de La Mancha Oriental y La Plana de Valencia. Además, aparte de los tres principales embalses de regulación (Alarcón, Contreras y Tous), también se incorpora el sistema de embalses de Molinar, Cortes, Naranjero y La Muela, que tienen una gran importancia para la generación de energía hidroeléctrica y para cubrir las necesidades de refrigeración de la Central Nuclear de Cofrentes.

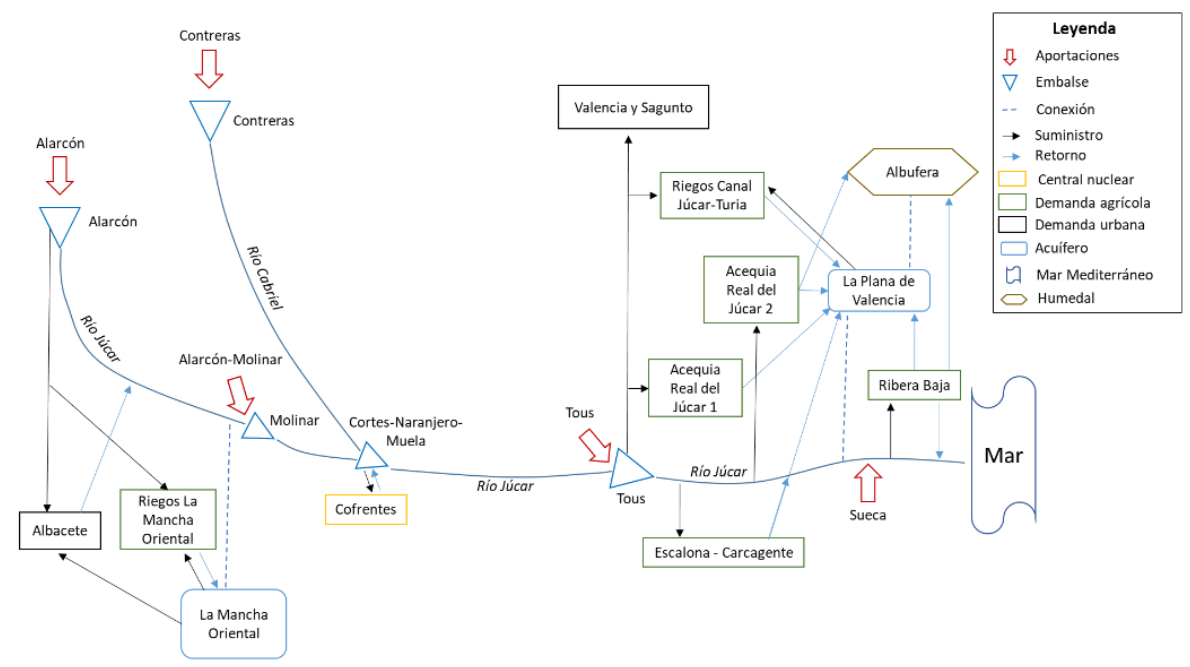

Fig. 7. Esquema simplificado del del SEJ. Modificado de Suárez-Almiñana et al. (2017). 


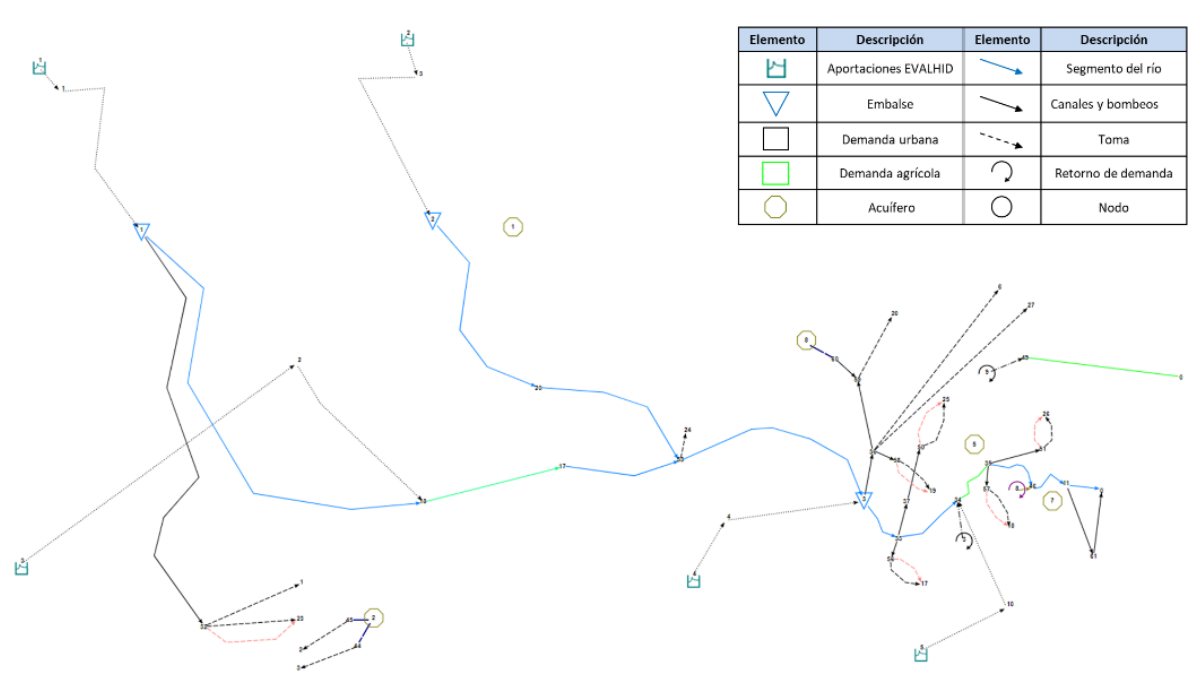

Fig. 8. Esquema del SEJ en SIMGES.

MASHWIN permite la construcción de modelos estocásticos multivariantes para generar series sintéticas múltiples y equiprobables, preservando las propiedades estadísticas de la serie original. Su principal utilidad es complementar al módulo SIMRISK, ya que este necesita múltiples escenarios futuros de aportaciones para realizar la evaluación del riesgo.

SIMRISK utiliza estos escenarios futuros de aportaciones para simular el modelo de gestión mediante el método de Monte-Carlo, tantas veces como series generadas. Cada simulación proporciona resultados diferentes, que se tratan estadísticamente para obtener la estimación probable de la situación del sistema al final de la campaña estudiada o después de varios años. Por lo tanto, esta herramienta puede ser utilizada a corto, medio y largo plazo. Además, es capaz de estimar el estado final del sistema al integrar medidas en el modelo, simulando diferentes escenarios de gestión para elegir los más efectivos con el objetivo de minimizar los impactos futuros.

Por último, el modelo RREA tiene como objetivo estimar el efecto de diferentes presiones ambientales sobre las masas de agua superficiales 
continentales a gran escala. Fue desarrollado para definir zonas no muestreadas con alto riesgo de contaminación, estimar la eficacia de las medidas de depuración o calcular la situación del sistema en diferentes escenarios (cambio climático, épocas de sequía, etc.), ya que es capaz de estimar concentraciones de contaminantes en cada masa de agua superficial teniendo en cuenta la carga que se aporta a cada masa, la contaminación que proviene de aguas arriba y la posible degradación que se produce en la propia masa de agua. Además, contempla la continuidad del flujo entre las sucesivas masas de agua y por tanto el efecto de cualquier medida sobre todo el sistema.

Para más información sobre este SSD o cualquiera de sus módulos puede consultarse su página web: https://aquatool.webs.upv.es

Además de este software, también se utilizó el programa estadístico $R$ (ver. 3.4.0) (R Core Team, 2020), y el programa de cálculo numérico Matlab (ver. R2020a) (Higham y Higham, 2016) para la extracción y preparación de los datos iniciales, su análisis estadístico, transformaciones como la normalización, estandarización y corrección del sesgo, además de la construcción de modelos y diferentes subrutinas que facilitan la automatización y eficiencia del proceso. Su uso en específico se puede encontrar en los diferentes artículos pertenecientes a esta tesis, presentados en las siguientes secciones. 


\section{PUBLICACIONES}

Esta tesis se presenta por compendio de artículos e incluye cuatro artículos científicos sometidos a revisión por pares, dos de ellos publicados en revistas indexadas en el Journal Citation Report (JCR) y otros dos publicados en una revista de prestigio en el ámbito de los recursos hídricos de habla hispana. A continuación, se listan las referencias de todos ellos y su indexación:

- Suárez-Almiñana, S., Pedro-Monzonís, M., Paredes-Arquiola, J., Andreu, J., Solera, A. (2017). Linking Pan-European data to the local scale for decision making for global change and water scarcity within water resources planning and management. Science of the Total Environment, 603-604,

126-139. https://doi.org/10.1016/j.scitotenv.2017.05.259. Indexada en el JRC y ubicada en el primer decil (Q1).

- Suárez-Almiñana, S., Solera, A., Andreu, J., García-Romero, L. (2020). Análisis de incertidumbre de las proyecciones climáticas en relación a las aportaciones históricas en la Cuenca del Júcar. Ingeniería del agua, 24(2), 89-99. https://doi.org/10.4995/la.2020.12149. Indexada en la Matriz de Información para el Análisis de Revistas (MIAR): $8.5<=$ ICDS $<10$.

- Suárez-Almiñana, S., Solera, A., Madrigal, J., Andreu, J., ParedesArquiola, J. (2020): Risk assessment in water resources planning under climate change at the Júcar River basin, Hydrology and Earth System Sciences, 24, 5297-5315, https://doi.org/10.5194/hess-245297-2020. Indexada en el JRC y ubicada en el primer decil (Q1).

- Suárez-Almiñana, S., Paredes-Arquiola, J., Andreu, J., Solera, A. (2021). Efecto del cambio climático en la calidad del agua de la cuenca del Júcar. Ingeniería del agua, 25(2), 215-235. https://doi.org/10.4995/la.2021.14644. Indexada en la MIAR: $8.5<=$ ICDS $<10$. 
En las siguientes secciones se presenta una breve descripción de cada uno de ellos previa a su versión de autor, centrada sobre todo en el desarrollo de una metodología de integración de las proyecciones climáticas en la gestión y planificación hidrológica para mejorar la toma de decisiones frente a futuros eventos extremos de sequía, el principal objetivo de esta tesis.

\subsection{Ajuste de los datos Pan-Europeos a la escala local para la toma de decisiones relacionadas con los impactos del cambio climático y la escasez hídrica en el marco de la planificación hídrológica}

En este artículo, se presentó una metodología innovadora que integra las proyecciones climáticas en la planificación hidrológica mediante el ajuste de los datos Pan-Europeos a escala local. De este modo, se pretende facilitar la toma de decisiones futura frente a situaciones de escasez hídrica y eventos extremos, como son las sequías, que previsiblemente serán más intensas y frecuentes debido al impacto del cambio climático (CEDEX, 2017).

En la Fig. 9 se puede observar la metodología propuesta, que está dividida en dos partes (dependiendo del origen de los datos empleados) y compuesta por una cadena de modelos que termina en el análisis de impacto derivado del cambio climático después de interactuar entre ellas.

El primer paso es la selección de datos Pan-Europeos o proyecciones de cambio climático y los datos históricos locales, en este caso de variables meteorológicas ( $\mathrm{P}$ y $\mathrm{T}$ ). Una vez escogidos los datos climáticos se compara un periodo de referencia común para analizar su ajuste y si es necesario realizar una corrección del sesgo. En el caso de que así sea, esta corrección se establece sobre la serie del periodo de referencia y después se extiende al periodo futuro mediante un coeficiente de corrección. 


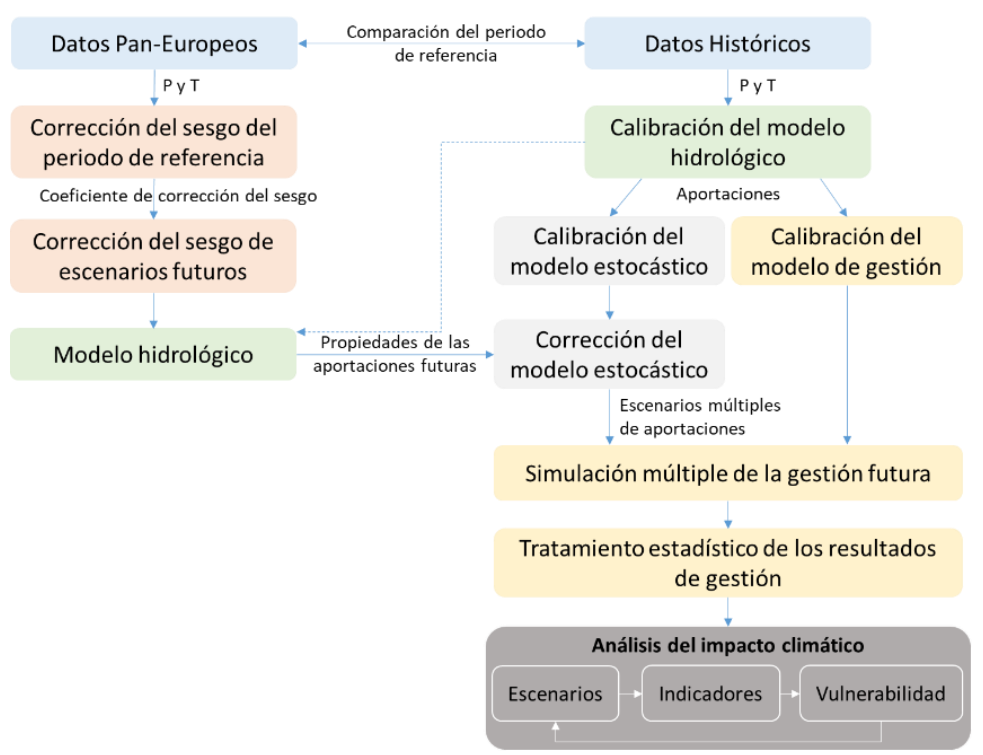

Fig. 9. Metodología de integración de proyecciones climáticas en la planificación hidrológica. Modificado de Suárez-Almiñana et al., (2017).

En el siguiente paso, las series corregidas se integran en un modelo hidrológico para obtener las aportaciones futuras. Este modelo, así como el estocástico y el de gestión son previamente calibrados con las aportaciones históricas. Sin embargo, para que el modelo estocástico funcione a futuro, se corrige con las propiedades estadísticas de las aportaciones futuras.

La principal función del modelo estocástico es generar múltiples series sintéticas de aportaciones futuras o escenarios para el análisis del impacto climático mediante indicadores probabilísticos del riesgo de sequía futuro. Como se ha comentado anteriormente, para llevar a cabo este análisis primero hay que desarrollar el modelo de gestión o de asignación de agua, en el que se integran todos los elementos principales del SRH a estudiar.

Una vez generados los múltiples escenarios, se simula el modelo de gestión para cada una de ellos y sus resultados se tratan estadísticamente para obtener indicadores de riesgo y así analizar la vulnerabilidad del sistema o los impactos derivados del cambio climático. Este proceso se 
puede desarrollar de forma iterativa si se desea testar la eficacia de ciertas medidas derivados de la toma de decisiones, aunque esta parte no fue integrada en el estudio.

Esta metodología genérica se aplicó al caso de estudio y es fácilmente replicable en cuencas complejas que presenten el mismo tipo de problemáticas relacionadas con la escasez hídrica, siempre y cuando se disponga de datos suficientes y conocimiento de experto.

Al adaptarla a la cuenca del Júcar se obtuvo una estimación futura del estado del sistema. Para ello se tuvieron en cuenta cuatro pasos importantes, que se detallan a continuación:

1- Recogida de datos: Los datos necesarios (5 subcuencas) provenientes de proyecciones climáticas y datos históricos son $\mathrm{P}, \mathrm{T}$ en ambos casos y aportaciones en el último. En el caso de las proyecciones climáticas, se partió de datos de $\mathrm{P}$ y $\mathrm{T}$ de 11 Modelos Climáticos Regionales (MCR) pertenecientes a las Sendas Representativas de Concentración (SRC) 2.6 (mitigación), 4.5 (estabilización) y 8.5 (mayores emisiones), extraídas de un modelo hidrológico a escala europea llamado E-HYPE (Hundecha et al., 2016). Estas proyecciones (Tabla 2), que están divididas en el periodo de referencia 1971-2000 y el periodo futuro 2011-2100, fueron desarrolladas y testadas durante el proyecto SWICCA, disponibles libremente en el servicio climático del Instituto Meteorológico e Hidrológico de Suecia (SMHI) (https://hypeweb.smhi.se/explore-water/climate-changedata/europe-climate-change/).

De aquí en adelante, utilizaremos la palabra conjunto o ensamblado (ensemble en inglés) cuando nos refiramos a un conjunto de predicciones, ya sea provinientes de diversos modelos como en el caso las proyecciones climáticas (Tabla 2) o de un único modelo como en el caso de los pronósticos estacionales (sección 2.5.1.). 
Tabla 2. Miembros del conjunto o ensamblado de las proyecciones climáticas del proyecto SWICCA. Modificado de Suárez-Almiñana et al. (2020b, 2017).

\begin{tabular}{|c|c|c|c|c|c|}
\hline SRC & MCG & MCR & Periodo & Instituto & Nombre \\
\hline \multirow{2}{*}{2.6} & EC-EARTH & RCA4 & $1970-2100$ & SMHI & $\begin{array}{c}\text { SMHI_RCA4_EC- } \\
\text { EARTH_rcp26 }\end{array}$ \\
\hline & MPI-ESM-LR & REMO2009 & $1951-2100$ & $\mathrm{CSC}$ & $\begin{array}{c}\text { CSC_REMO2009_MPI- } \\
\text { ESM-LR_rcp26 }\end{array}$ \\
\hline \multirow{5}{*}{4.5} & EC-EARTH & RCA4 & $1970-2100$ & SMHI & $\begin{array}{c}\text { SMHI_RCA4_EC- } \\
\text { EARTH_rcp45 }\end{array}$ \\
\hline & EC-EARTH & RACMO22E & $1951-2100$ & KNMI & $\begin{array}{c}\text { KNMI_RACMO22E_EC- } \\
\text { EARTH_rcp45 }\end{array}$ \\
\hline & HadGEM2-ES & RCA4 & $1970-2098$ & SMHI & $\begin{array}{c}\text { SMHI_RCA4_HadGEM2- } \\
\text { ES_rcp45 }\end{array}$ \\
\hline & MPI-ESM-LR & REMO2009 & $1951-2100$ & $\mathrm{CSC}$ & $\begin{array}{c}\text { CSC_REMO2009_MPI- } \\
\text { ESM-LR_rcp45 }\end{array}$ \\
\hline & CM5A & WRF33 & $1971-2100$ & IPSL & $\begin{array}{c}\text { IPSL-IPSL-CM5A- } \\
\text { MR_rcp45 }\end{array}$ \\
\hline \multirow{4}{*}{8.5} & EC-EARTH & RCA4 & $1970-2100$ & SMHI & $\begin{array}{l}\text { SMHI_RCA4_EC- } \\
\text { EARTH_rcp85 }\end{array}$ \\
\hline & EC-EARTH & RACMO22E & $1951-2100$ & KNMI & $\begin{array}{c}\text { KNMI_RACMO22E_EC- } \\
\text { EARTH_rcp85 }\end{array}$ \\
\hline & HadGEM2-ES & RCA4 & $1970-2098$ & SMHI & $\begin{array}{c}\text { SMHI_RCA4_HadGEM2- } \\
\text { ES_rcp85 }\end{array}$ \\
\hline & MPI-ESM-LR & REMO2009 & $1951-2100$ & CSC & $\begin{array}{c}\text { CSC_REMO2009_MPI- } \\
\text { ESM-LR_rcp85 }\end{array}$ \\
\hline
\end{tabular}

En este caso nos centramos en el horizonte 2039 (periodo 20292049), ya que se corresponde con varios ciclos de planificación futuros previos al 2050 (punto de inflexión de las SRC), el de 20332039 y $2039-2045$.

Los datos de $\mathrm{P}$ y $\mathrm{T}$ históricos provienen de una base de datos de observaciones a escala nacional llamada Spain02 (Herrera et al., 2012) para el periodo 1950-2003.

Los datos de aportaciones históricos en régimen natural para calibrar los modelos fueron proporcionados por la CHJ, periodo 1980-2012. 
2- Análisis de los datos disponibles: El periodo de referencia 1971-2000 de ambos tipos de datos fueron comparados y corregidos mediante un coeficiente de corrección basado en las diferencias respecto de la media del ensamblado en el año medio. En este caso solo se consideró la corrección de las $\mathrm{P}$, ya que el desajuste era muy pronunciado.

3- Calibración de los modelos: Todos los modelos fueron calibrados con las aportaciones históricas empleando periodos a partir de 1980 para considerar el efecto 80 y obtener simulaciones más acordes a la situación actual del sistema.

Producto del modelo hidrológico o de precipitación-escorentía HBV (Bergström, 1995), incluido en EVALHID, se obtuvieron las aportaciones futuras a partir de las $\mathrm{P}$ corregidas y la ETP prcedente de la T mediante la aplicación del método de Hargreaves (Hargreaves y Samani, 1985). Las medias de estas aportaciones futuras se usaron para corregir el modelo estocástico, en este caso un modelo autoregresivo de primer orden $A R(1)$, y se generaron 1000 series de 30 años (los mismos que en el periodo de referencia) por MCR para el horizonte 2039.

4- Análisis del impacto climático: Una vez generados los múltiples escenarios, se simula el modelo de gestión para cada una de ellos, tratando sus resultados estadísticamente mediante el método de Monte-Carlo en el modelo de evaluación del riesgo (SIMRISK), del que se obtiene un indicador de riesgo basado en la evolución de los recursos hídricos del sistema para el año medio del horizonte 2039.

Los principales resultados muestran una gran incertidumbre futura, ya que a pesar de detectar una reducción de las aportaciones en el horizonte estudiado, los indicadores de riesgo provenientes de los MCR son mucho más optimistas que el estimado para la situación actual. Esto puede indicar que los cambios esperados para el futuro ya hayan 
ocurrido en esta cuenca, ya que el periodo de referencia de las proyecciones climáticas no tiene en cuenta el cambio de tendencia experimentado en los últimos 30 años (efecto 80). Por lo tanto, una mejora de las proyecciones climáticas es necesaria en esta área, así como futuras mejoras de la metodología propuesta, con el fin de proporcionar diferentes opciones de modelaje en el proceso adaptativo a cuencas complejas.

A continuación, se puede ver la versión de autor del siguiente artículo, con el permiso de todos los coautores:

Suárez-Almiñana, S., Pedro-Monzonís, M., Paredes-Arquiola, J., Andreu, J., Solera, A. (2017). Linking Pan-European data to the local scale for decision making for global change and water scarcity within water resources planning and management. Science of the Total Environment, 603-604, 126-139. https://doi.org/10.1016/j.scitotenv.2017.05.259

\section{Linking Pan-European data to the local scale for decision making for global change and water scarcity within water resources planning and management}

Sara Suárez-Almiñana ${ }^{1 *}$, María Pedro-Monzonís ${ }^{1}$, Javier Paredes-Arquiola1, Joaquín Andreu ${ }^{1}$ and Abel Solera ${ }^{1}$

${ }^{1}$ Research Institute of Water and Environmental Engineering (IIAMA), Universitat Politècnica de València, Valencia (Spain)

*sasual@upv.es 


\begin{abstract}
This study focuses on a novel type of methodology which connects PanEuropean data to the local scale in the field of water resources management. This methodology is proposed to improve and facilitate the decision making within the planning and management of water resources, taking into account climate change and its expected impacts. Our main point of interest is focused on the assessment of the predictability of extreme events and their possible effects, specifically droughts and water scarcity. Consequently, the Júcar River Basin was selected as the case study, due to the ongoing water scarcity problems and the last drought episodes suffered in the Mediterranean region.
\end{abstract}

In order to study these possible impacts, we developed a modeling chain divided into four steps, they are: i) data collection, ii) analysis of available data, iii) models calibration and iv) climate impact analysis. Over previous steps, we used climate data from 11 different regional climate models (RCM) belonging to the three different Representative Climate Pathways (RCP) coming from a hydrological model across all of Europe called E-HYPE. The data were bias corrected and used to obtain statistical results of the availability of water resources for the future (horizon 2039) and in form of indicators. This was performed through a hydrological (EVALHID), stochastic (MASHWIN) and risk management (SIMRISK) models, all of which were specifically calibrated for this basin.

The results show that the availability of water resources is much more enthusiastic than in the current situation, indicating the possibility that climate change, which was predicted to occur in the future has already happened in the Júcar River Basin. It seems that the so called "Effect 80", an important decrease in water resources for the last three decades, is not well contemplated in the initial data.

Keywords: climate services, Júcar River Basin, climate change, Pan-European data, AQUATOOL DSSS 


\section{Introduction}

Climate change is a natural process that has been accelerated by human influence, due to the huge amount of emissions of greenhouse gases into the atmosphere. It is related to human development, growth and consumption patterns (Vargas-Amelin and Pindado, 2014), and currently these emissions are the highest in history (IPCC, 2014). However, it is not the only factor that contributes to climate change, as could volcanic activity and ocean circulation also be contributors, however burning fossil fuels and industrial processes have been recognised by scientific communities as the main contributors that have increased the concentration of $\mathrm{CO} 2$ in the atmosphere (IPCC, 2014), consequently these factors could be the main contributors that are responsible for the increase of the Earth's temperature.

In addition, it is known that the Mediterranean area is becoming drier, and therefore more vulnerable to wildfires and drought. There is an elevated probability that Mediterranean river basins, as many other semiarid regions, will suffer an important decline in water resources availability attributable to climate change (Vargas-Amelin and Pindado, 2014). In the coming years, it is expected that the increasing water demand in combination with water scarcity due to climate change will intensify the current water stress.

Many studies suggest that climate change will amplify the frequency of current problems (Bates et al., 2008), and within Europe, Spain is one of the most exposed countries to climate change, caused by its socio-economic and geographic features (MMA, 2005). Moreover, the general pattern of the projected models indicate a decrease in precipitation and an increase in temperature for this area (Estrela et al., 2012; Garrote, 2009), within its limitations regarding the uncertainty, the spatial resolution, the projections range and their complexity among others. This could lead to an intense competition between different user groups and sectors due to the possible prolonged periods of water scarcity where water is already limited today 
(van Vliet et al., 2015), all related to social, economic and environmental impacts. Thus, it seems clear that the adaptation to climate change necessarily implies the participation of scientists, governments and society.

In this sense, the European Union (EU) Roadmap on climate services (European Commission, 2015) represents the convergence between society's actionable research and the faculty of the climate research community to support personalized knowledge, information and data (van den Hurk et al., 2016). Therefore, if society is aware of the existence of a reliable forecast, then the anticipation for extreme events could become a very operative adaptation measure (van den Hurk et al., 2016).

Knowing all this, a new methodology based on a modeling chain (hydrological, stochastic and management models) is presented in this paper with the aim of creating a link between climate services and decisionmaking in water resources planning and management at the river basin scale. It is based on the application of a decision support system, in order to support adaptation, mitigation and reduce risk disasters. To accomplish with this objective, the assessment of the effects of global change in the Júcar River Basin (east of Spain) was performed to evaluate if current urban and agricultural requirements could be suitably met under future changing scenarios.

This process begins with Pan-European climatic data from the E-HYPE hydrological model belonging to the SWICCA Copernicus Project (Service for Water Indicators in Climate Change Adaptation). This projects aim is to bridge the gap between institutes who provide climate-impact data on one side, and water managers and policy makers on the other. As several authors have highlighted (Donnelly et al., 2016), the E-HYPE model presents some inconveniences in the Mediterranean area, presenting some gaps in evapotranspiration, aquifers and water extraction among others (Donnelly et al., 2016). Thus, it was necessary to correct climate data and use a modeling chain specifically calibrated for this area. The importance of this is to obtain reliable results that should be able to detect future periods of 
drought and avoid the possible impacts associated with them. In this sense, it could be possible to know of droughts in advance and make the right decisions by preventing impacts to water resources availability in the future. In addition, it could be incorporated to other countries or river basins affected by water scarcity into water planning.

\section{Materials and methods}

The methodology presented in Figure 1 was developed to connect PanEuropean data to the local scale in order to assess the state of the system and to propose the measures required in future periods, taking into account the impacts of water scarcity due to global warming. It is represented by two pathways (depending on the origin of the data), which interact with one another and finally converge in a final step.

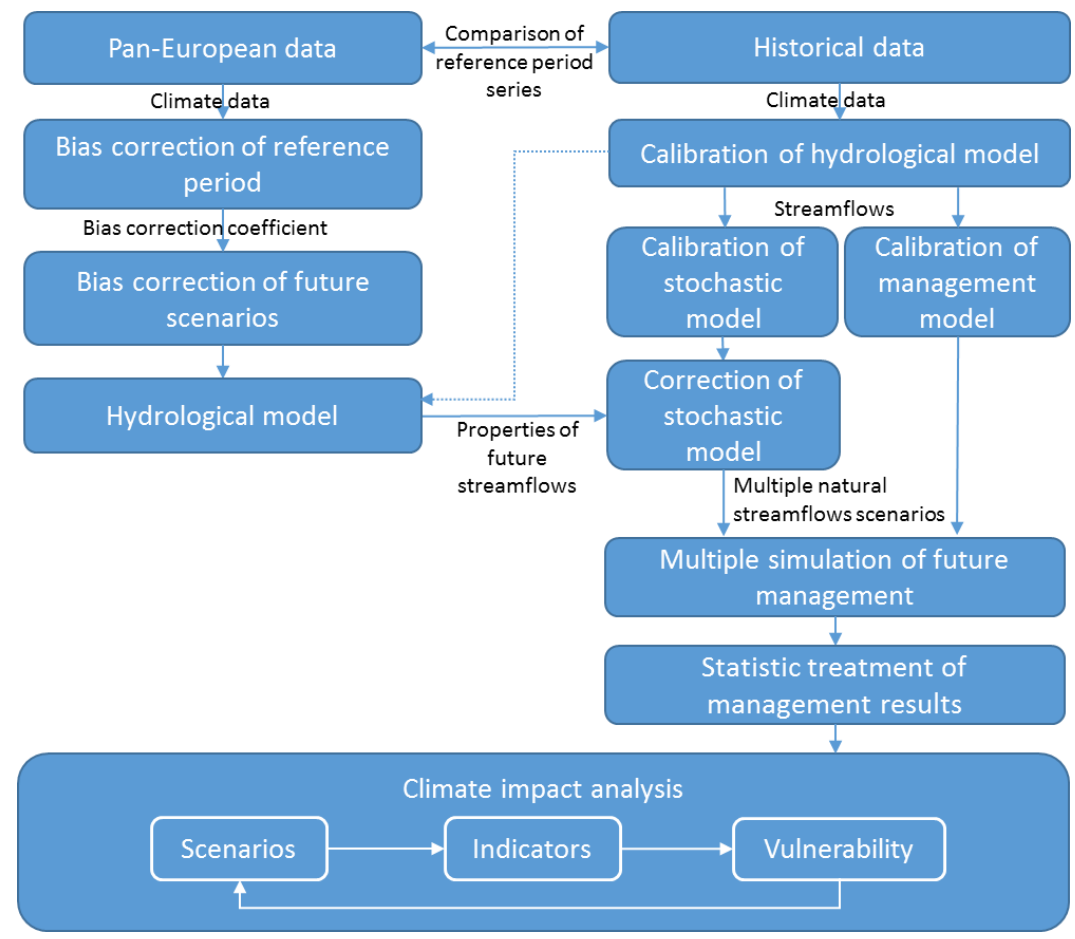

Figure 1. Methodology scheme for climate impact analysis in water resources planning and management. 
Pan-European and historical data collection are the first step of the methodology. Once data series' are obtained, a reference period is selected and both data are compared to know the accuracy of the forecast and to obtain a bias correction coefficient for correcting future scenarios. On the other hand, historical data are also used for model calibration. Firstly, the stochastic model is employed to generate multiple streamflow series equiprobable with the historical ones. Secondly, the previous generated series' are used to analyze multiple runs of the water management model, obtaining multiple different management results. Both ways are related for the correction of the stochastic model, which is done with the properties of corrected future scenarios. Finally, the climate impact analysis is performed for different regional climate models (RCM) in order to obtain several indicators and asses the vulnerability of the system, with the aim of applying some adaptation measures and mitigate the impacts of climate change. The application of these measures can be considered as a new scenario, because of that, the final step is a close-loop process. This procedure is explained below in more detail, it is divided in several steps, which are: 1- Data collection; 2- Analysis of the available data; 3- Models calibration; 4- Climate impact analysis.

Step 1: Data collection - The data required come from Pan-European and local databases, it includes: river flows, precipitation, potential evapotranspiration and temperature (minimum, average and maximum).

Pan-European data come from the SWICCA Copernicus project, which has developed a website that enables the download of climate, hydrological and indicators data from all over Europe (http://swicca.climate.copernicus.eu/) at different space and time resolutions. In this sense, based on the most appropriate space resolution for this research (catchment resolution, $215 \mathrm{~km}^{2}$ ), data from the E-HYPE hydrological model (Hundecha et al., 2016) were used. E-HYPE uses global databases and Global Monitoring for the Environment and Security (GMES) satellite products as input data and then is forced by the European Centre 
for Medium-Range Weather Forecasts (ECMWF) and the Swedish Meteorological and Hydrological Institute (SMHI) to calculate the water balance, hydrological variables and daily discharge for the entire continent (Hundecha et al., 2016). Some of the uses of this model are hydrological forecasts, water allocation, predictions for ungauged basins, climate change impact assessments and hydraulic flood models.

Table 1. Characteristics of the 11 Regional Climate Model data provided by E-HYPE hydrological model. (Modified from: http://swicca.climate.copernicus.eu/wpcontent/uploads/2016/10/Metadata_Precipitation_catchment.pdf).

\begin{tabular}{|c|c|c|c|c|}
\hline \multicolumn{5}{|c|}{ Model input/forcing } \\
\hline $\mathbf{R} C P$ & GCM & RCM & Period & Institute \\
\hline \multirow{2}{*}{$\mathbf{2 . 6}$} & EC-EARTH & RCA4 & $1970-2100$ & SMHI \\
\cline { 2 - 6 } & MPI-ESM-LR & REMO2009 & $1951-2100$ & CSC \\
\hline \multirow{4}{*}{$\mathbf{4}$} & EC-EARTH & RCA4 & $1970-2100$ & SMHI \\
\cline { 2 - 6 } & EC-EARTH & RACMO22E & $1951-2100$ & KNMI \\
\cline { 2 - 6 } & HadGEM2-ES & RCA4 & $1970-2098$ & SMHI \\
\cline { 2 - 6 } & MPI-ESM-LR & REMO2009 & $1951-2100$ & CSC \\
\hline \multirow{4}{*}{$\mathbf{8 . 5}$} & CM5A & WRF33 & $1971-2100$ & IPSL \\
\hline & EC-EARTH & RCA4 & $1970-2100$ & SMHI \\
\cline { 2 - 6 } & HadGEM2-ES & RCA4 & $1970-2098$ & SMHI \\
\hline & MPI-ESM-LR & REMO2009 & $1951-2100$ & CSC \\
\hline
\end{tabular}

Therefore, we disposed the daily time series of precipitation, temperature and river flows from the period of 1971-2100 (using the years 1971-2000 as a reference period) and for 11 different RCMs, belonging to the three Representative Concentration Pathways (RCP) (2.6 mitigation, 4.5 stabilization and 8.5 high greenhouse gas scenarios). In Table 1, the different ensembles and their origin (Global Climate Model and Institute) are presented. On the other hand, historical data come from the Spain02 database (Herrera et al., 2012), conformed by an observations grid of approximately $20 \mathrm{~km}$ of spatial resolution for the period 1950-2003. Thus, 
we dispose data from the same reference period on which we are going to analyze on both E-HYPE model, as well as Spain02, from 1971 to 2000.

Step 2: Analysis of the available data - In this step the comparison between both data, Pan-European and historical is performed, in order to know the accuracy of the forecast in the reference period (1971-2000) and to apply a bias correction for the entire period (1971-2100) in case their differences are notable. Two types of comparisons were performed, firstly, with river flows from the same points, coinciding with the main sub-basins of the system, where the main reservoirs are placed. Secondly, the comparison was done with climate data, comparing the $11 \mathrm{RCMs}$ with historical data and extracting a bias correction coefficient based on the differences between historical data and an average of all RCMs. With these corrected data, it is possible to extract river flows with a hydrological model to feed other models that reveal the performance of the system.

Step 3: Models calibration - In this section historical data are employed to calibrate a hydrological model for the case study, and then, its outputs, as natural river flows, are used for the calibration of stochastic and management models.

The stochastic model was corrected with the properties, the mean in this case, of bias corrected future period series of river flows from step 2. It is used to generate multiple synthetic series' of river flows for different future scenarios. On the other hand, the historical outputs of the hydrological model are utilized as inputs for the calibration of the management model, where all important elements of the Júcar River water allocation system are incorporated.

In the specific case of the groundwater modeling, there are two types of aquifers, the most important is a multicellular aquifer (La Mancha Oriental aquifer) whose relationship with the surface system depends on a law represented by different discharge coefficients identified as cells, which would be two in this case. The other is a single cell-aquifer whose 
relationship with the surface system is such that the surface system receives the drainage from the aquifer, normally in the form of a spring. These were calibrated with a contrast of the outputs to the river and the gauging balance.

Regarding the models validation, the hydrological model was validated with the streamflows series of several years coming from gauging stations from non-altered areas. The management model was validated by the River Basin Agency with gauging data specified in the Júcar River Basin Management Plan (Annex 6).

Step 4: Climate impact simulation - At this step, multiple runs of the water management model are performed. This model provides information about the evolution of water supplies considering different scenarios. In this final step, the climate impact analysis is performed as a closed-loop process, this means using the new scenarios, where an adaptation measures has been applied, and verifying if those measures could be effective or not through the evaluation of this indicator.

The methodology can be followed using different methods and models. We used the AQUATOOL Decision Support System Shell (DSSS) (Andreu et al., 1996) and its associated modules which are described below. AQUATOOL DSSS is user-friendly for water resources planning and management and is used at a national and international level. This software has been evolving over time to cover the major problems related to water management and facilitate the related work in the same tool. Thus, it has integrated several modules related to the assessment of water resources through rainfall-runoff modeling, the simulation and optimization of basin management and water quality modeling, among others.

The EVALHID module (Paredes-Arquiola et al., 2012) is used to develop a hydrological model in complex basins and its main goal is to evaluate the amount of water resources generated in each basin. This module has integrated several rainfall-runoff models and all of them have been 
aggregated with semi distributed applications at the sub-basin scale. They can be chosen depending on the available data, the complexity of the basin and the users experience in the development and calibration of hydrological models.

The SIMRISK module (Sánchez-Quispe et al., 2001) evaluates the management risks in the short, medium and long-term for a certain river basin. The process used is based on the Monte-Carlo method. It consists of generating multiple, future and equiprobable natural streamflow scenarios, and simulating the management of the system according to the criteria defined previously for each scenario. Each simulation will provide different results, which are statistically treated in order to obtain the probable estimation of the final situation of the system at the end of the present campaign, or after two or more hydrological years.

The MASHWIN module (http://www.upv.es/aquatool/es/index_es.html) is used to analyze the historical hydrological inflow series and the formulation of stochastic models for generating synthetic series. Its principal utility is to complement the SIMRISK module, generating the different scenario series of future hydrological inflows.

\section{Case study: The Júcar River Basin}

\subsection{Description of the basin}

The Júcar River Basin is one of the nine water exploitation systems of the Júcar River Basin District, which is placed in the East of the Iberian Peninsula (Figure 2) and flows into the Mediterranean Sea. In this district, the Júcar River Basin is the main water exploitation system due to its extension $\left(22,186.61 \mathrm{~km}^{2}\right)$ and the volume of water resources $\left(1,605.4 \mathrm{hm}^{3} /\right.$ year). Its drainage area belongs to the provinces of Cuenca, Teruel, Albacete and Valencia. 

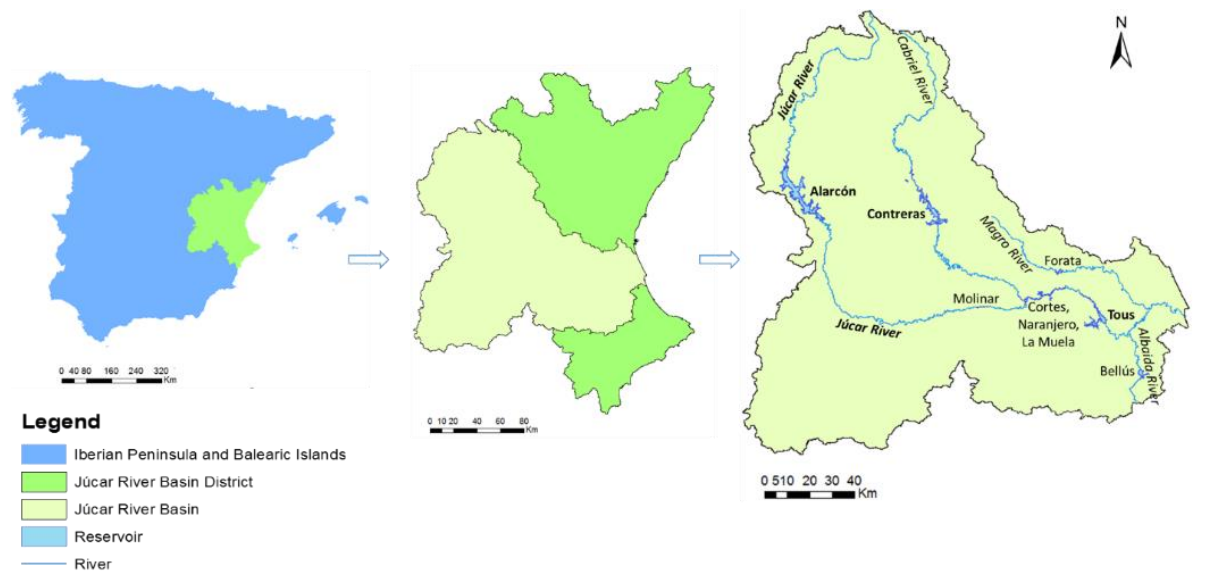

Figure 2. Location of the Júcar River Basin in the Iberian Peninsula.

In the inland part of this basin (north) is the mountainous area of the Iberic System, which works as a barrier for maritime fronts that force wet clouds to reach higher atmospheric layers and therefore, leave rainfall in this mountainous region. The coastal plain is formed by alluvial materials from the Neogene, where the nutrients of the soil support the major part of the irrigated agricultural production. Then, La Mancha (south west of the basin) is an area between the Iberic and Betic mountainous systems, characterized by a plain surface with an average altitude of $650 \mathrm{~m}$.

In addition, the formation of wetlands is another important feature of this basin. These wetlands are included in the RAMSAR international list and are fed from groundwater and from superficial runoff (in minor quantity). The most important wetland is La Albufera de Valencia, placed in the costal part of the basin with an area of 21.120 hectare, which is also composed of a vast extension of rice crops and a shoal that separates the lake to the Mediterranean Sea.

Moreover, the major part of this area is covered by permeable materials that facilitate the rainfall infiltration to the underground, for example, the formation of karst by dissolution processes, resulting in interconnected cavities and fractures originated in rocks like limestone and dolomites. 
This area has a typical Mediterranean climate, which is characterized by warm summers and mild winters, with an average precipitation of 475.2 $\mathrm{mm} /$ year and a potential evapotranspiration of $926.6 \mathrm{~mm} / \mathrm{year}$. The annual average temperatures are about 14 and $16.5^{\circ} \mathrm{C}$, where maximum degrees are reached during the months of July and August (dry season). In addition, during the months of October and November the phenomenon called "gota fría", a cold front with intense and short term precipitations may occur.

This basin owes its name to Júcar River, it is $512 \mathrm{~km}$ long and its main tributaries are the Cabriel, Albaida and Magro rivers. The hydrology is marked by the features of the Mediterranean climate, as can be the semiaridity and the low precipitation rate mentioned before, which in combination with punctual torrential rains lead to floods and summer scarcity, resulting in a high seasonality and recurrent multiannual droughts.

The main reservoirs in the river basin are the Alarcón, Contreras and Tous dams, which jointly with groundwater aquifer, supply many different uses dominated by urban and agricultural demands, estimated at 203.37 $\mathrm{hm}^{3} /$ year and 1,397.67 $\mathrm{hm}^{3} /$ year (Confederación Hidrográfica del Júcar, $2015)$, respectively. The irrigated area covers 210,638 ha, which represents $54 \%$ of the whole district, note that the irrigation requirements do not coincide with the rainy season. Consequently, this is an adjusted system with an important relation between groundwater and surface resources. The relationship between water demands and water resources shows an indicator of water stress with a ratio of about $84 \%$, which means there is high scarcity and exploitation of the system. Due to the adjusted balance between water resources and demands, some measures were suggested and implemented, such as the reuse of sewage water, which is about 18.28 $\mathrm{hm}^{3} /$ year and it is expected to be higher in the coming years.

\subsection{Modeling the Júcar River Basin by using AQUATOOL DSS}

The methodology proposed in section 2 was applied to the Júcar River Basin, which was divided into five sub-basins, which are: 
- Alarcón: This sub-basin covers the head of the Júcar River, which lies in the Montes Universales, to the Alarcón reservoir.

- Alarcón - Molinar: This area covers the intermediate river basin of the Júcar River between the Alarcón and El Molinar reservoirs.

- Contreras: This area covers the catchment area of the Cabriel River, upstream of the Contreras reservoir.

- Tous: This area covers the intermediate river basin of the Júcar River between El Molinar, Contreras, and Tous reservoirs.

- Sueca: This area covers downstream of the Tous reservoir to the Huerto Mulet gauging station.

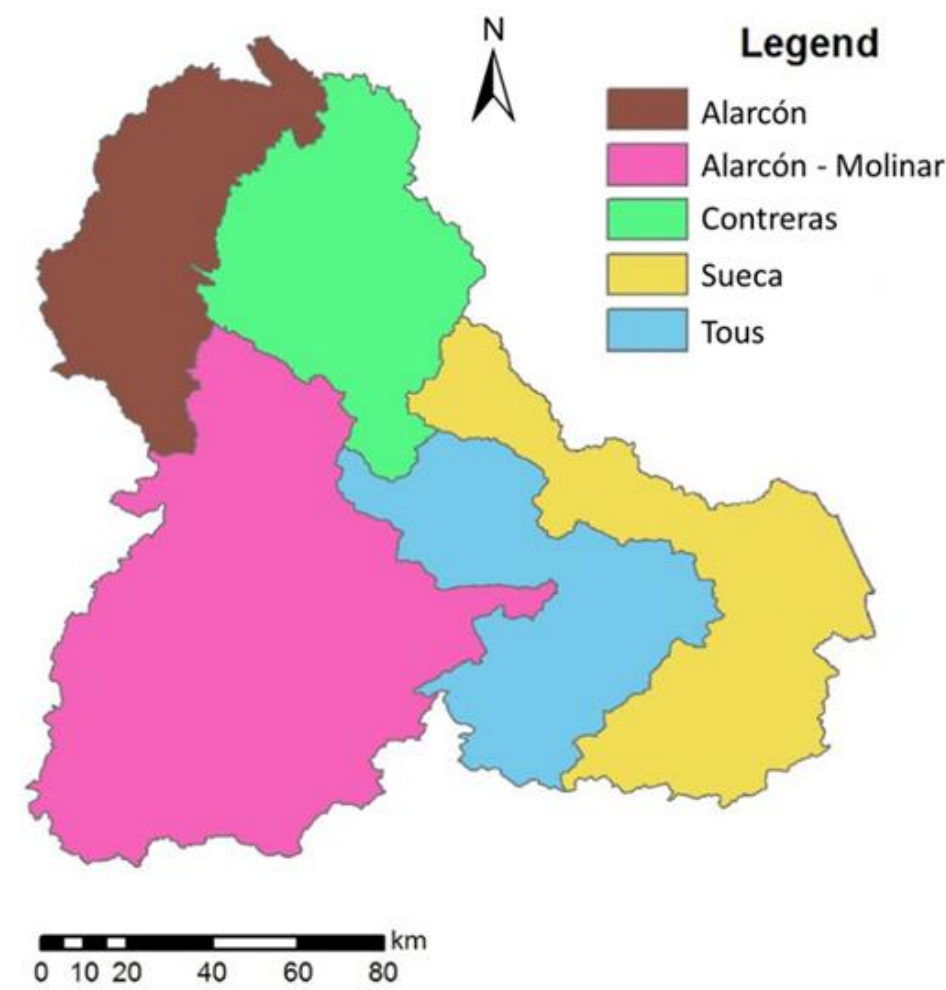

Figure 3. Sub-basins considered for modeling the Júcar River Basin.

These sub-basins were employed in the hydrological model of the Júcar River Basin developed with EVALHID (Merino, 2012). Among the several 
rainfall-runoff models included in EVALHID, the HBV model (Hydrologiska Byråns Vattenbalans-avdelning) (Bergström and Forsman, 1973) was selected due to its versatility and the obtained results in comparison with other models in the case study. This model was performed with historical data of precipitation and temperature daily time series from the Spain02 database (Herrera et al., 2012) during the reference period of 1971-2000, which is characterized by a spatial resolution of $20 \mathrm{~km}$. Potential evapotranspiration (PET) was calculated by the Hargreaves method (Hargreaves and Samani, 1985).

Based on Pan-European temperature and precipitation data provided by the E-HYPE model (Hundecha et al., 2016) described in the materials and methods section (Table 1), bias correction was applied to the ensemble scenario composed of the monthly average values of temperature and precipitation in each of the five sub-basins considered for the reference period (1971-2000) (Figure 3). This decision was justified by two reasons; firstly, the results of applying the bias correction for each future scenario considered separately were analogous in each sub-basin, and secondly, the use of an ensemble scenario reduces the number of parameters. The values of precipitation and temperature accepted as historical data in the reference period come from the Spain02 database (Herrera et al., 2012), which has been employed in the formulation of water balances in other similar works (Pedro-Monzonís et al., 2016). Once temperature and precipitation data were bias corrected, they were used in the hydrological model developed with EVALHID. Therefore, 11 time series results of river flows were obtained for each of the future climate scenarios considered in Table 1 . These series' were simulated at the daily scale and then they were accumulated to the monthly scale for the next step.

On the other hand, a multivariate ARMA $(1,0)$ monthly model (Salas et al., 1980) was adjusted using the historical monthly streamflow time series from 1980 to 2012, the period which is considered valid for basin planning. This model enables the generation of multiple equiprobable time series of 
river flows. According to the proposed methodology, 1,000 streamflow data series' were generated for each of the future scenarios considered. However, it has been observed that within future climate scenarios, the average of the river flows time series is changing during the years, specifically, the more pessimistic the greenhouse gas scenario is the greater reduction in river flows are over the years. Considering this fact and taking into account that this analysis is focused on water planning, instead of maintaining the historical average values of the river flows for the generated series, the average value considered was the average value of the climate scenarios on dates close to the planning horizon (2039). In this way, the model calibrated with historical streamflows data in natural regime has been altered in its parameters of the monthly average replacing them with those obtained from the selected future horizon (2039). Thus, 1,000 streamflow data series' were generated with 30 years length. The initial month of the analysis was October, which corresponds to the beginning of the hydrological cycle in the northern hemisphere. 30 years length is justified because the analyzed period must be as long as the reference period in order to allow comparisons.

The following step corresponds to the water management simulation model. It was built using the SIMGES module (Andreu et al., 1996), which is part of AQUATOOL DSSS, and the calibration was performed by using historical river flows for the period of 1980-2012. Figure 4 shows a representation of the Júcar Water Exploitation System with the main elements. This model was validated with observed data and it is a simplification of the model employed by the Júcar River Basin Agency ( $\mathrm{CHJ})$. As it is presented, the supplies of the main urban and irrigation demands proceed from both surface and groundwater resources. The main regulation reservoirs are the Alarcón, Contreras and Tous, which provide both a flood abatement capacity and the supply for water demands. Also included are a system of reservoirs (Molinar, Cortes, Naranjero and La Muela), which have great importance for hydropower generation (Solera et 
al., in press). The main aquifers are La Mancha Oriental and La Plana de Valencia, that are exploited for water supply.

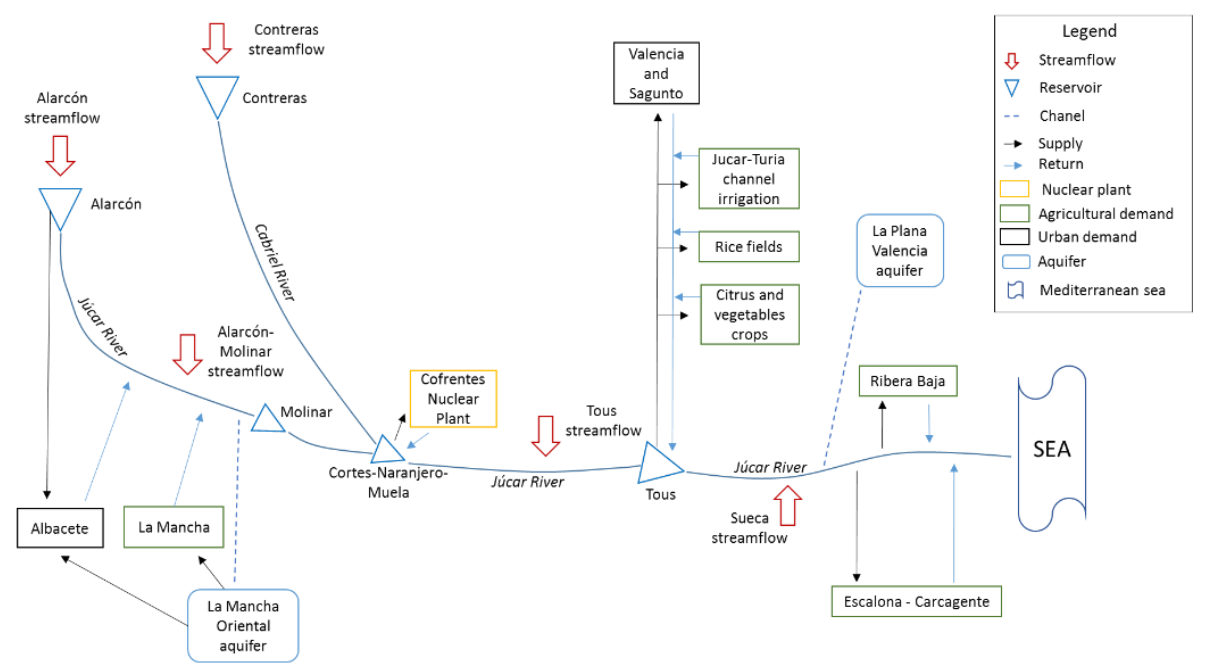

Figure 4. Scheme of the Júcar Exploitation System with the most relevant elements included in the simulation model.

Developing a water management model is a requirement before applying the SIMRISK approach. In this sense, the simulation of the generated series is performed by the SIMRISK module in order to analyze the climate change impacts on the case study for future periods. This model enables decision makers to know the probability of supply failures as it includes the estimation of the performance of the water resources system, in addition to know the evolution of water supplies and water reserves. Thus, these statistical results enable the assessment of the vulnerability of the case study by employing the volume of water stored in the main reservoirs of the system as an indicator for the adaptation to climate change. In other words, climate change predictions allow decision makers to adopt the required measures in order to reduce the vulnerability of the system. 


\section{Results}

\subsection{Precipitation bias correction results and PET estimation}

Firstly, a comparison between the precipitation values provided by PanEuropean data and the historical ones from the reference period is necessary to verify the consistency and reliability of the data. This assessment was done for the five sub-basins defined in section 3.2 and it is presented in Figure 5. In order to remove possible errors from the climate models, a bias correction was applied to transform Pan-European data into more similar observations. This bias correction was based on a monthly rate resulting from the differences between both averages for each month. The comparison of precipitation for the reference period showed an underestimation mainly in the winter months.

Similarly, for obtaining the PET, the Hargreaves method (Hargreaves and Samani, 1985) was applied by using historical data. This formula requires average, maximum and minimum temperature (Tmean, Tmax and Tmin, respectively). As Tmean is the only variable available in the Pan-European database, we proceeded with the average temperature from the PanEuropean data and use Tmax and Tmin from the historical data to obtain the PET of the reference period. Based on this, the result of the average PET for the reference period fits with the historical data, being that the highest values are in the summer months, as expected. Then, PET was obtained for future periods based on the average temperature from forecasts and correcting it with the average temperature from the reference period. This procedure was done using an adapted formula from the mentioned method. Yearly aggregated results can be observed in Figure 6, where it becomes more evident how the average annual PET from different RCMs starts to diverge from the year 2050 . 

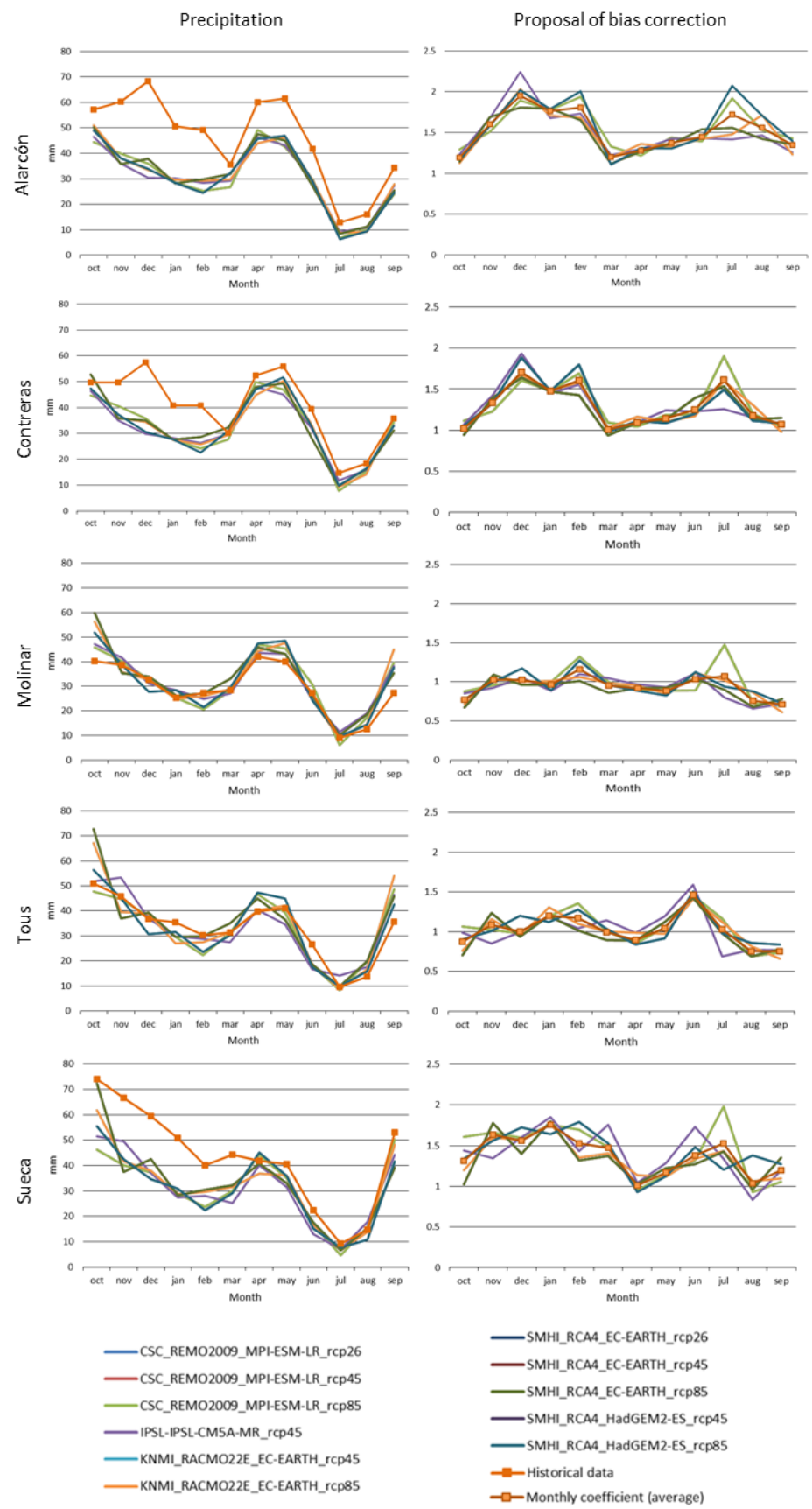

Figure 5. Precipitation, proposal of bias correction for each of the five sub-basins included in the hydrological model. 

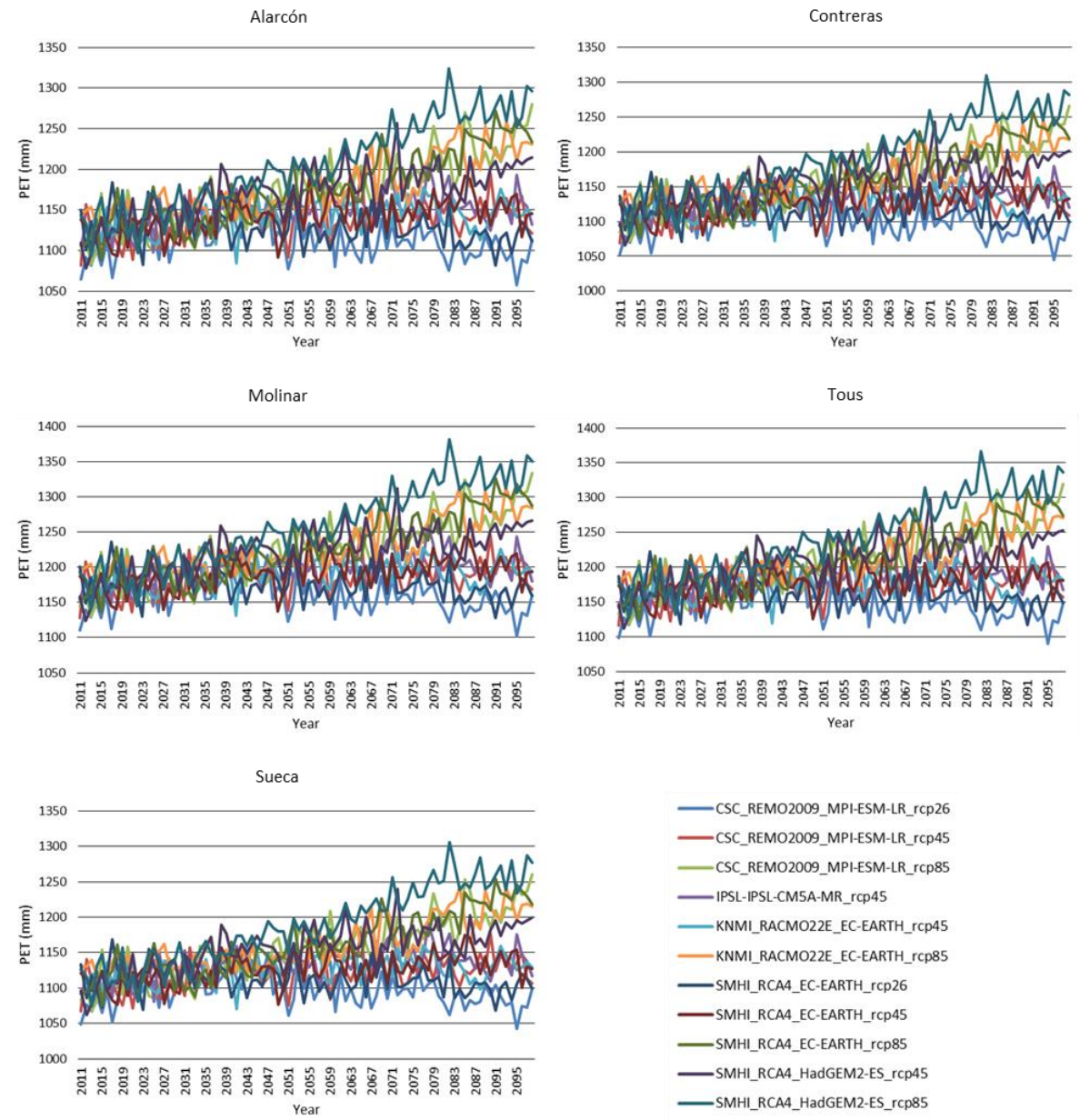

Figure 6. PET for each of the five sub-basins included in the hydrological model.

\subsection{Hydrological model results for the future change scenarios}

Once precipitation and PET have been corrected, it is possible to extract streamflows time series from the hydrological model for the future period of interest. The period 2011-2100 was simulated for each one of the 11 RCMs considered, since each model is given by different conditions. Figure 7.a represents the total annual streamflow in the whole basin for all scenarios. As observed, there is a decreasing trend in the streamflows time series. In addition, a large behavioral difference among the scenarios is 
detected. On the other hand, according to the next planning period, which corresponds with 2021-2027, climate change impacts are evaluated in the 2039 horizon, so in order to study this horizon, we consider as a representative period, a margin of ten years before and after 2039. Figure 7.b shows the average annual streamflows for the period 2029-2049. Some results indicate an increase in the average streamflows in the river basin while others show a decrease.

a)

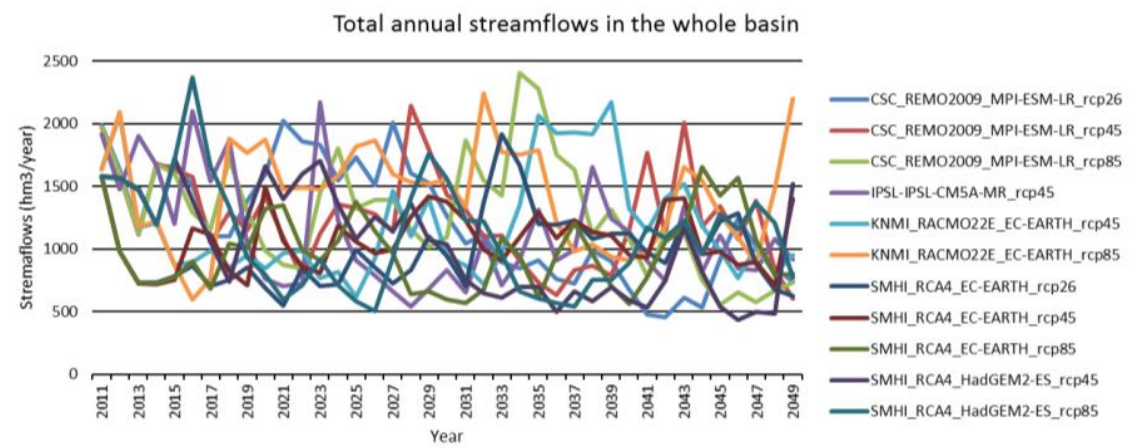

b)

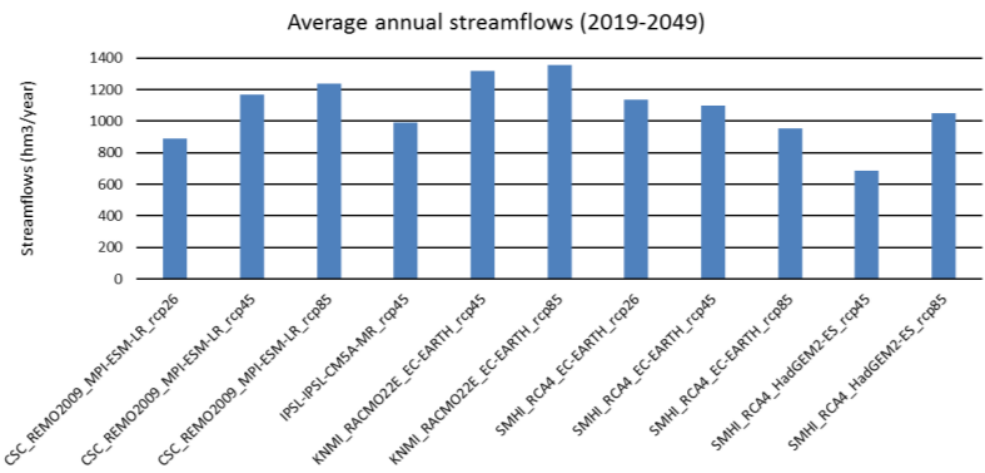

Figure 7. Hydrological model results for the future change scenarios.

\subsection{Hydrological projections analysis}

Table 2 presents the basic statistics for the historical series and the adjusted ones. Note that there are several periods to take into account. Firstly, period 1970-2000 coincides with the reference period of Pan- 
European data. Timeframe $1980-2012$ is the one used in river basin management plans for the second planning period (MAGRAMA, 2016). Climate change projections cover the years 2011 to 2100. Finally, climate change impacts are evaluated in the 2039 horizon, and it is defined with the average value from 2029 to 2049 .

For the analysis of the water management in the 2039 horizon, the variation in the average values of streamflows in the river basin will be considered. For the rest of the statistical and stochastic properties of the time series of streamflows, it is considered that the values obtained from the historical series are maintained. 1,000 streamflow time series were generated with 30 years duration and 4 years warm-up period to avoid dependences with the initial condition.

Table 2. Yearly statistics for different time series.

\begin{tabular}{|c|c|c|c|c|c|}
\hline & $\begin{array}{c}\text { Basic } \\
\text { statistics }\end{array}$ & $\begin{array}{l}\text { Historical series } \\
\text { from reference } \\
\text { period (1971-2000) }\end{array}$ & $\begin{array}{c}\text { Historical series } \\
(1980-2012)\end{array}$ & $\begin{array}{c}\text { Adjusted series } \\
(2011-2100)\end{array}$ & $\begin{array}{l}\text { Adjusted series } \\
\text { (2029-2049) }\end{array}$ \\
\hline \multirow{4}{*}{ Alarcón } & Average & 342.8 & 286.8 & 182.2 & 131.9 \\
\hline & $\begin{array}{l}\text { Standard } \\
\text { Deviation }\end{array}$ & 174.3 & 140.2 & 121.2 & 66.1 \\
\hline & Bias & 0.7 & 0.7 & 1.4 & 0.7 \\
\hline & $\begin{array}{c}\text { Correlation } \\
\text { coefficient (r1) }\end{array}$ & 0.4 & 0.21 & 0.44 & 0.41 \\
\hline \multirow{4}{*}{ Contreras } & Average & 312.5 & 253.1 & 194.6 & 159.8 \\
\hline & $\begin{array}{l}\text { Standard } \\
\text { Deviation }\end{array}$ & 160.2 & 136.3 & 95.0 & 84.2 \\
\hline & Bias & 0.5 & 1.0 & 1.7 & 0.7 \\
\hline & $\begin{array}{c}\text { Correlation } \\
\text { coefficient (r1) }\end{array}$ & 0.5 & 0.30 & 0.73 & 0.76 \\
\hline \multirow{4}{*}{ Molinar } & Average & 286.7 & 238.9 & 246.3 & 173.1 \\
\hline & $\begin{array}{l}\text { Standard } \\
\text { Deviation }\end{array}$ & 72.9 & 43.8 & 143.1 & 77.5 \\
\hline & Bias & 0.4 & 0.7 & 1.3 & 0.8 \\
\hline & $\begin{array}{c}\text { Correlation } \\
\text { coefficient }(r 1)\end{array}$ & 0.9 & 0.55 & 0.56 & 0.47 \\
\hline \multirow{4}{*}{ Tous } & Average & 207.5 & 168.3 & 224.3 & 218.6 \\
\hline & $\begin{array}{l}\text { Standard } \\
\text { Deviation }\end{array}$ & 93.7 & 44.2 & 76.5 & 88.4 \\
\hline & Bias & 1.8 & 0.3 & 0.5 & 0.2 \\
\hline & $\begin{array}{c}\text { Correlation } \\
\text { coefficient }(r 1)\end{array}$ & 0.8 & 0.36 & 0.70 & 0.54 \\
\hline \multirow{4}{*}{ Sueca } & Average & 232.6 & 241.8 & 196.2 & 136.1 \\
\hline & $\begin{array}{l}\text { Standard } \\
\text { Deviation }\end{array}$ & 122.9 & 115.2 & 81.3 & 43.5 \\
\hline & Bias & 0.7 & 0.7 & 1.2 & 0.6 \\
\hline & $\begin{array}{c}\text { Correlation } \\
\text { coefficient ( } \mathrm{r} 1)\end{array}$ & 0.6 & 0.56 & 0.84 & 0.37 \\
\hline
\end{tabular}


As observed, standard deviation is higher in historical period than in adjusted ones. In this sense, the generation of synthetic series is based only on the average values.

\subsection{Analysis of water management scenarios}

This section presents the results obtained from SIMRISK model. The streamflows time series' used are obtained with the stochastic model calibrated for 1980-2012 period. As 1,000 streamflows time series' were generated, now we dispose 1,000 simulations of water management in the river basin. These results will be statistically treated.

Figure 8 presents the probability of having $10 \%, 20 \%, 30 \%, 40 \%, 50 \%$, $60 \%, 70 \%, 80 \%$ and $90 \%$ of the total volume of the addition of the three reservoirs for the average year, as $1,796 \mathrm{hm}^{3}$, is the total capacity of these reservoirs. This scenario considers the current water requirements, which corresponds with the Júcar River Basin Management Plan (RBMP) and amount to $1,083 \mathrm{hm}^{3}$. As expected, when requirements are higher, it is more likely that reservoirs are empty. Within the average year, as the irrigation season proceeds, which is from April to September, it is more likely that reservoirs are emptied. Note that water requirements are equal or even higher than water resources in the Júcar River Basin.

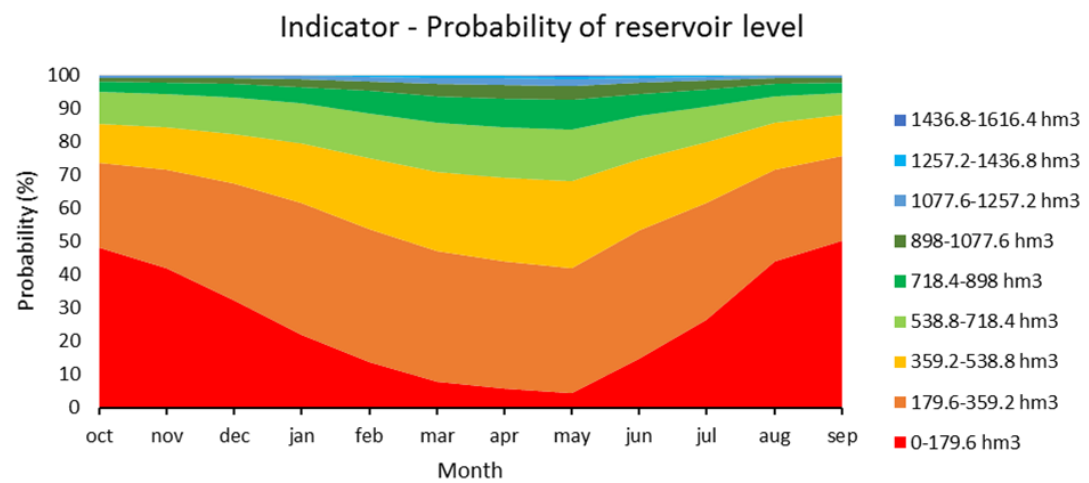

Figure 8. Statistical probabilities of having water resources in each month as a result of the management model, for the current scenario. 


\subsection{Analysis of future water management scenarios}

Considering climate change projections, Figure 9 presents the probability for the average year that the Alarcón, Contreras and Tous reservoirs are full, the 2039 time horizon for each one of the 11 RCMs is considered in Table 1.

Indicator - Probability of reservoir level depending on RCMs
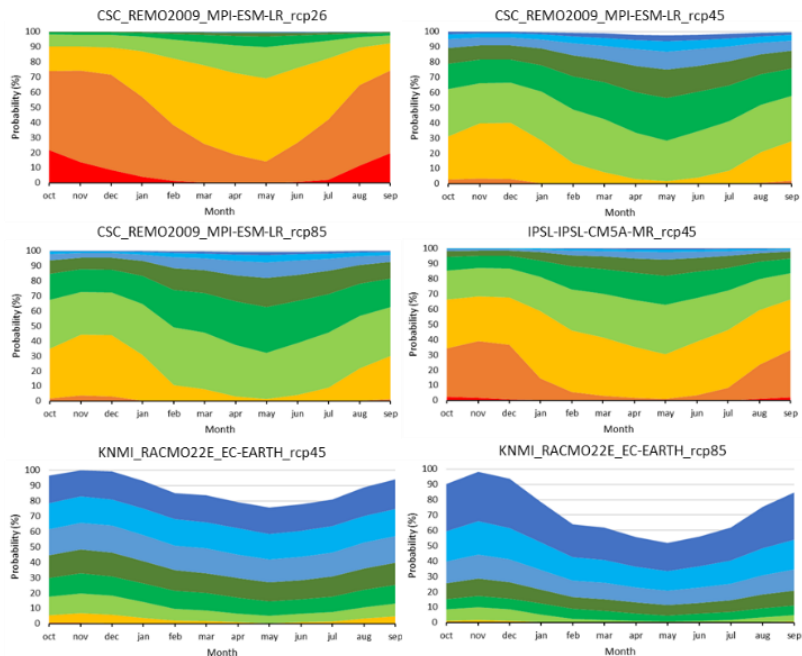

KNMI_RACMO22E_EC-EARTH_rCP85
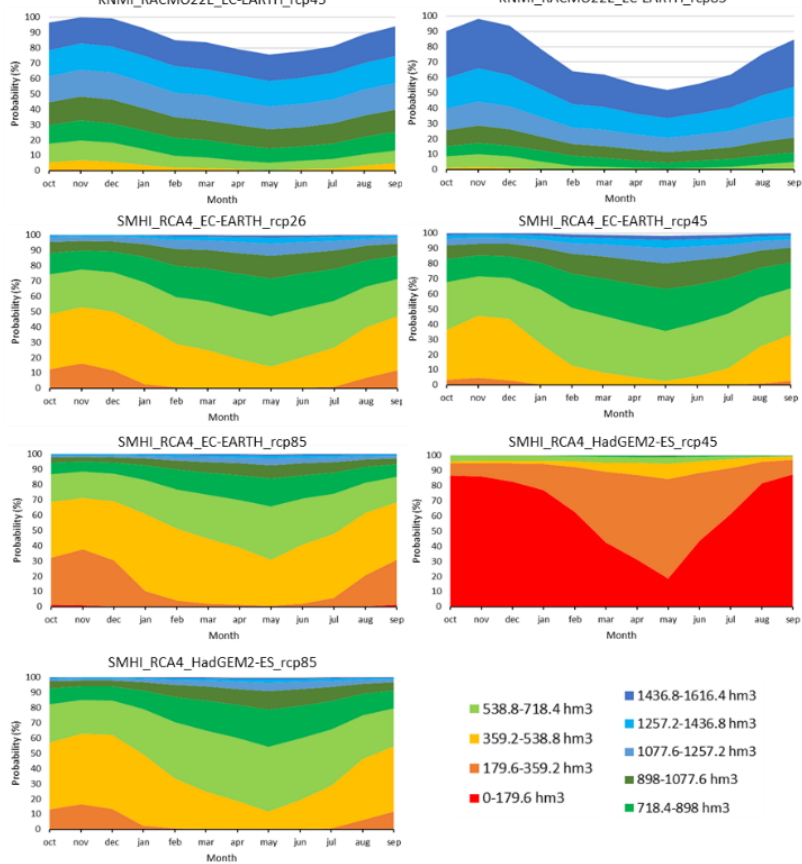

SMHI_RCA4_EC-EARTH_rCP45

$=538.8-718.4 \mathrm{hm} 3$

$=359.2-538.8 \mathrm{hm} 3$

$=179.6-359.2 \mathrm{hm} 3$

=1436.8-1616.4 hm3 $=1257.2-1436.8 \mathrm{hm} 3$ $=1077.6-1257.2 \mathrm{hm} 3$

- 0-179.6 hm3

= 898-1077.6 hm3

$=718.4-898 \mathrm{hm} 3$

Figure 9. Statistical probabilities of having water resources in each month as a result of the management model, for each RCM. 
This scenario also considers the current water requirements, as section 4.4 does. By the way, some graphics do not reach $100 \%$, this lack of data indicates that the reservoirs are completely full, as the maximum values presented in charts are up to $1,616 \mathrm{hm}^{3}$, and the total capacity reaches $1,796 \mathrm{hm}^{3}$. Regarding to the variations on the groundwater reserves, specifically from the La Mancha Oriental aquifer, these levels follow the tendency of the reliabilities shown in Figure 9. This means that when the probability of having full reservoirs is high, aquifer levels tends to rise, while when this probability is lower, the aquifer tends to have lower levels.

Contrary to what one might expect, in general, results for the 2039 time horizon are much more optimistic than results obtained in previous sections. Further, only one of the eleven RCMs considered present lower levels of water stored in reservoirs than the simulation obtained from 19802012, where the explanation can be found in Table 2. The Average streamflows obtained in the reference period 1970-2000 are considerably higher than the ones calculated with historical data in the period used in the Júcar RBMP (1980-2012). In this sense, a future horizon has been obtained based on a more optimistic reference period with values of streamflows higher than the historical water resources.

This is a serious discussion, because in Spanish Mediterranean river basins a change in precipitation and temperature patterns occurred the beginning of the 1980s. This fact is not detected in the reference period of $\mathrm{RCM}$. Then the question about projections of climate change is whether this change refers to the far historical data or it refers to the last 20 years. The point is that in this case study the change has just occurred, and in terms of water resources, it is higher than most of the prognostics obtained in future climate scenarios.

Observing other statistical parameters in future scenarios presented in Table 2, there are some interesting differences that could contribute to the obtained results. The standard deviation and the bias coefficient in inflows to the main reservoirs of the river basin are much smaller in the adjusted 
series than in the historical period. It implies inflows similar to the average values but not so frequently being less than the average.

\section{Discussion}

This study is based on an innovative methodology that combines the use of Pan-European data with hydrological models, stochastic models and multiple simulations of future management focused on water planning. In this field, other works have been conducted with certain nuances. As an example, Haro et al. (2014) analyzes a risk assessment approach within-year operated systems in order to estimate the probability of operative drought in the forthcoming months. So, depending on the risk associated, it would be necessary to anticipate mitigation measures to ensure water supplies for the upcoming irrigation season. Gil et al. (2011) propose a methodology for handling the risk associated with water supply variability in irrigated agriculture by using Monte Carlo simulations of crop production 7 and 3 months before the irrigation season. In the case study analyzed in this paper, the multiple simulations of future management are focused on longterm water planning. In this way, this approach assists water managers and decision makers in the application of strategic measures within future global change. According to Vargas-Amelin and Pindado (2014) in the coming years an increase in supply from non-conventional resources is expected in Spain, such as desalination or wastewater reuse, along with the modernization of irrigation systems. The high costs of these infrastructures and their environmental impacts require a long-term evaluation.

While analyzing each of the steps proposed in the methodology, it is noteworthy to highlight the difficulties encountered for applying the bias correction in streamflows. The comparison performed in section 4.1 was also applied to streamflows from the E-HYPE model and historical data for the reference period of 1971-2000. These were obtained as naturalized river flows, from the same five sub-basins where the main reservoirs are placed (Alarcón, Contreras, Molinar, Tous, Bellús and Sueca). This comparison (Figure 10) allowed us to detect that all scenarios from Pan- 
European data reached $0 \mathrm{~m} 3 / \mathrm{s}$ during summer months. The explanation for these results is that the Pan-European hydrological model underestimates the groundwater component of river flows during the dry season. In summer months, the main flows of the Júcar River are due to the discharges from the aquifers, a very important feature for the management of the Júcar Water Exploitation System. In addition, there is an overestimation of inflows in winter months. Thus, with these null values in summer months it was not possible to apply a bias correction. To overcome this inconvenience, it was necessary to resort the use of hydrological models. Thus, the new alternative consisted in doing the same comparison with climate data (precipitation and PET), and then, correcting it and extracting PET to use them in the hydrological model in order to extract streamflows for each sub-basin. This inconvenience is also described in Teutschbein and Seibert (2012), who indicates that although RCMs simulate surface and groundwater runoff, these results do not often fit with streamflows observations and therefore they should not be directly used for assessing hydrological impacts at the catchment scale.
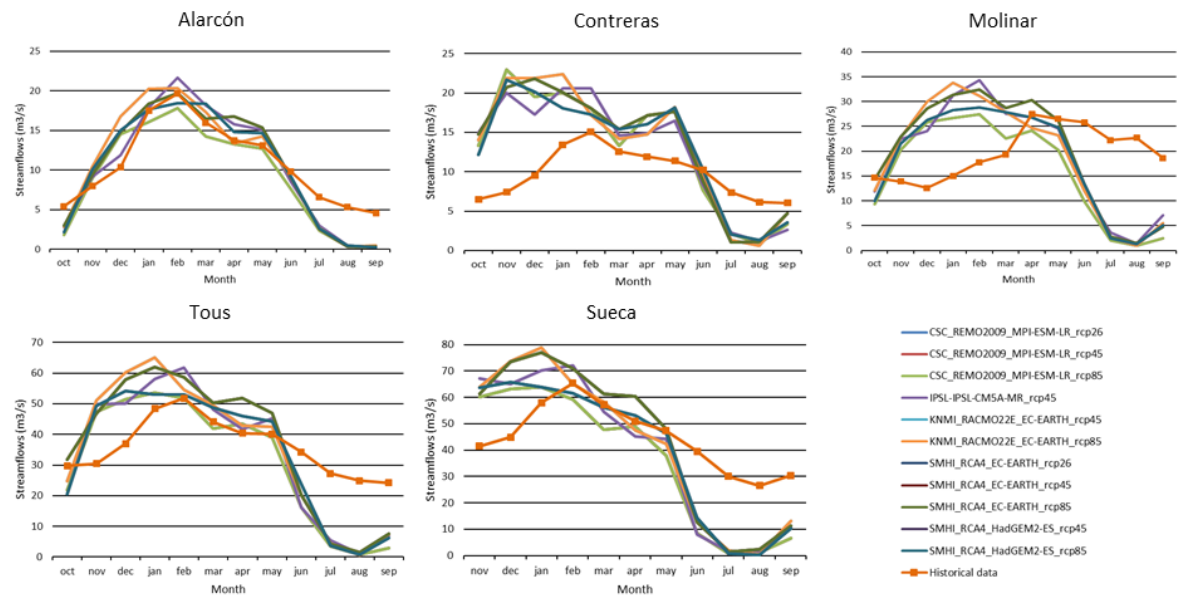

Figure 10. Comparison between streamflows from Pan-European and historical data for each of the five sub-basins included in the hydrological model. 
Actually, according to Donnelly et al. (2016), the results of the E-HYPE model do not completely fit with the observations (E-HYPE) of the Mediterranean areas, being its major weaknesses as the resolution of precipitation patterns, aquifer exchanges, water extractions and regulation. Moreover, it is highlighted that an improvement is needed in areas of southern Europe, like Spain, where there are overestimations of water volume in certain seasons due to the underestimation of irrigation extractions and groundwater recharge (Donnelly et al., 2016). In addition, Andersson et al. (2015) remarked that making simple improvements to input data could result in significant gains in the performance of the model. In this sense, the key factors to improve the performance of the HYPE model in large-scale applications are related to refine the catchment delineation, meteorological input data, and model parameterisation (Andersson et al., 2015).

As noted by Pulido-Velazquez et al. (2011), little interest has been taken to regionalization techniques to assess the impacts of global change on water resources systems in both runoff and groundwater recharge. Being a fact of great importance in conjunctive-use systems, as the Júcar River Basin is. The quality of bias-corrected RCMs is strongly dependent on the selected algorithm, and simulations driven with adjusted RCM variables are best suited to observed values than results forced with unadjusted RCM climate variables (Teutschbein and Seibert, 2012). Nevertheless, we should not forget the inconveniences of bias correction. On the one hand, it cannot alleviate the existence of incorrect representations of dynamic and/or physical processes and, on the other hand, it considers that the bias is stationary even in the long term, as noted by (Marcos-Garcia and PulidoVelazquez, 2017; Teutschbein and Seibert, 2012).

The results provided by the hydrological model create doubts concerning the traditional assessment of climate change in Spanish water planning (MAGRAMA, 2008), which is considered by multiplying the streamflows time series by a reducing factor. This approach presents the 
advantage of its simplicity preserving the patterns of spatial and temporal variability observed but instead, it does not consider potential changes in the probability distribution of streamflows (Marcos-Garcia and PulidoVelazquez, 2017). As an example, considering the scenario "CSC_REM02009_MPI-ESM-LR_rcp26", the average streamflows for the entire river basin in the 2039 time horizon is $887 \mathrm{hm}^{3} /$ year. In this sense, Table 3 shows the relationship between the median values of each time series in each month for the future horizon considered with respect to the historical data in the period 1980-2012. Variations of streamflows by zones are observed. In the headwaters (Alarcón, Contreras and Molinar) the winter streamflows (which are the most important) are reduced, during the summer they remain similar, and in the lower basin they increase considerably. The largest increase occurs in the streamflows downstream to the last regulation reservoir, Sueca, which may imply that these resources are not usable in its entirety. In the case of the Júcar River District, the percentage of decrease in natural streamflows to incorporate the effect of climate change is 9\% (MAGRAMA, 2008). This percentage is in contrast with the results of Table 3, which in the best-case, the reduction amounts to $24 \%$ (Tous streamflows) and, in the worst case, it amounts to 52\% (Alarcón) in comparison with 1980-2012 period.

\begin{tabular}{|c|c|c|c|c|c|c|c|c|c|c|c|}
\hline & Alarcón & Contreras & Mancha & Tous & Sueca & & Alarcón & Contreras & Mancha & Tous & Sueca \\
\hline oct & 0.91 & 1.40 & 0.72 & 1.14 & 0.91 & \multirow{2}{*}{$\begin{array}{c}\text { Long historical } \\
\text { series } \\
(1940-2012) \\
\end{array}$} & \multirow{2}{*}{396} & \multirow{2}{*}{342} & \multirow{2}{*}{683} & \multirow{2}{*}{1273} & \multirow{2}{*}{1500} \\
\hline nov & 0.65 & 1.04 & 0.69 & 0.99 & 0.86 & & & & & & \\
\hline dic & 0.52 & 0.68 & 0.67 & 0.80 & 0.77 & \multirow{3}{*}{\begin{tabular}{|c} 
Short historical \\
series \\
$(1980-2012)$ \\
\end{tabular}} & \multirow{3}{*}{288} & \multirow{3}{*}{253} & \multirow{3}{*}{527} & \multirow{3}{*}{949} & \multirow{3}{*}{1192} \\
\hline ene & 0.38 & 0.52 & 0.56 & 0.66 & 0.63 & & & & & & \\
\hline feb & 0.45 & 0.53 & 0.61 & 0.69 & 0.64 & & & & & & \\
\hline mar & 0.44 & 0.57 & 0.62 & 0.71 & 0.67 & \multirow[t]{2}{*}{$\begin{array}{c}\text { Horizon } 2039 \\
\text { projection }\end{array}$} & \multirow[t]{2}{*}{138} & \multirow[t]{2}{*}{168} & \multirow[t]{2}{*}{320} & \multirow[t]{2}{*}{717} & \multirow[t]{2}{*}{860} \\
\hline abr & 0.34 & 0.46 & 0.50 & 0.60 & 0.59 & & & & & & \\
\hline may & 0.35 & 0.47 & 0.51 & 0.59 & 0.60 & \multirow{2}{*}{$\begin{array}{c}\text { Future } \\
\text { projection/ } \\
\text { long series }\end{array}$} & \multirow[b]{2}{*}{$35 \%$} & \multirow[b]{2}{*}{$49 \%$} & \multirow[b]{2}{*}{$47 \%$} & \multirow[b]{2}{*}{$56 \%$} & \multirow[b]{2}{*}{$57 \%$} \\
\hline jun & 0.43 & 0.55 & 0.55 & 0.67 & 0.68 & & & & & & \\
\hline jul & 0.55 & 0.74 & 0.62 & 0.79 & 0.82 & \multirow{3}{*}{$\begin{array}{l}\text { Future } \\
\text { projection/ } \\
\text { short series }\end{array}$} & \multirow{3}{*}{$48 \%$} & \multirow{3}{*}{$66 \%$} & \multirow{3}{*}{$61 \%$} & \multirow{3}{*}{$76 \%$} & \multirow{3}{*}{$72 \%$} \\
\hline ago & 0.59 & 0.81 & 0.62 & 0.79 & 0.86 & & & & & & \\
\hline sep & 1.02 & 0.94 & 0.77 & 0.93 & 0.85 & & & & & & \\
\hline
\end{tabular}

Table 3. Average streamflows obtained for the 2039 horizon using CSC_REMO2009_MPIESM-LR_rcp26 compared with 1980-2012 period.

At this point, it is required to highlight that the results of the hydrological model are crucial to simulate the conjunctive-use of water in the case study. In order to estimate the effects of climate change on aquifer 
recharge, other researches have handled this issue by assuming the aquifer recharge to be proportional to the difference between evaporation and precipitation (Pulido-Velazquez et al., 2011).

Concerning the results of future management scenarios, different values of streamflows have been considered. Nevertheless, operating rules have been maintained. In this respect, as noted by (Macian-Sorribes and PulidoVelazquez, 2017) operating rules support guidance to the system managers, but it is required to adjust them to the conditions. Moreover, there is a relationship between the hydrological state of the system and the type of measure to be applied (Pedro-Monzonís et al., 2015). Therefore, these operating rules will depend on the basin drought status, which future works will be directed towards improving this fact. As far as the model of the system used is concerned, the use of a simulation model aims to explore the performance of the system under the existing operating rules, whereas the use of an optimization model, as proposed by Haro et al. (2014), enables the best feasible management of the system. The latter approach could be the most appropriate in short-term water management, as stated before.

Regarding the results obtained in section 4.4 and 4.5 , there is a chance that climate change that has been predicted for the future has already occurred in the Júcar River Basin. The Júcar Water Exploitation System is characterized by a marked reduction in natural streamflows throughout the past 30 years, clearly showing the existence of two periods (before and after the 80s), in which the difference between their averaged streamflows is close to $500 \mathrm{hm}^{3}$ per year (Pérez-Martín et al., 2013). These changes in the climate are not reflected in the RCM in the geography of the Júcar River Basin. These changes that were not detected could be the reason for the optimistic results, where the average of the total available water resources in the reference period (1971-2000) provided by the E-HYPE model is higher than the reality. In this sense, it would be recommendable to divide the reference period into two periods; before and after the $80 \mathrm{~s}$, in order to 
begin the analysis with more realistic data and to obtain reliable results for decision-making.

As mentioned above, the methodology presented comprises several steps, and each of these steps requires an exhaustive and detailed analysis, since they adds great uncertainties and that the decisions based on them can affect the final results. These uncertainties are introduced by RCMs themselves due to the uncertainty related to future greenhouse gas emissions, the climate system response, or the formulation climate models to produce future scenarios (Kjellström et al., 2016; Teutschbein and Seibert, 2012), and also by the proposed modeling chain, in the hydrological model (Marcos-Garcia and Pulido-Velazquez, 2017), in the stochastic model results and in the water management model itself. In this sense, according to Pulido-Velazquez et al. (2011), the impacts caused by climate change and the required adaptation strategies are scenario dependent, or even more, methodological dependent.

It is therefore necessary to appoint that all these processes are framed within the climatic services. Just like the SWICCA platform, there are other climate service prototypes such as the Stadtbaukasten (Cortekar et al., 2016), which is focused on adapting cities to the projected changes on time, or the Swedish climate service (Kjellström et al., 2016), which is centered on RCMs from the Rossby Centre RCM RCA4. In all cases, these climate services are intended to connect climate scientists, decision-makers and users of climate information in general, to know what is going on with the climate, and how to respond and act on future weather realities (van den Hurk et al., 2016).

Finally, this work has been able to detect some constraints. First of all, the E-HYPE model needs some improvements in order to capture the real features of this Mediterranean area. Also, the bias correction could have been performed with a more accurate method for the case of precipitation and in an easier way for the temperature, if all data had been available to apply the Hargreaves method for obtaining the PET. On the other hand, we 
must not neglect the limitations of the models (hydrological, stochastic and management) developed in this research as all of them represent a simplification of a complex system, which can lead to the misleading of some important factors. Sometimes, these kinds of studies need to incorporate new points of view and the reformulation of the approach.

\section{Conclusions}

The main objective of this research is to develop, implement and validate a novel approach to link climate services with decision-making in water resources planning and management within climate change and water scarcity. The methodology presented comprises several steps consisting of a hydrological model, a stochastic model and multiple runs of a water management model. Each of these steps requires an exhaustive and detailed analysis, since the decisions considered for them can influence the final results. This uncertainty is added on the one provided by the RCM. One of the main improvements of the proposed approach is its capability for operating with complex systems, as it has been demonstrated in the case study analyzed, providing an overall representation of the state of the system.

We have applied this modeling chain to the Júcar Water Exploitation System. It has demonstrated that contrary to expected, results for the future time horizon 2039 are much more enthusiastic than results obtained in the current situation, as it is built on a more optimistic reference period with values of water resources greater than the historical ones. In this sense, results indicate that there is the possibility that climate change expected for the future has already happened in our case study.

Another envisaged alternative is that the RCMs do not work correctly in this area, as they do not contain the important change in the climate patterns that has been registered during the last three decades. In any case, more extensive research is needed in each step of this process. Bias correction could be reformulated in other parameters, and climate models 
should be revised trying to explain the real change in the climate, which has happened in recent history.

\section{Acknowledgements}

The authors thank the anonymous reviewers for their valuable comments, suggestions and positive feedback. All remaining errors, however, are solely the responsibility of the authors. We would also like to express our gratitude to the Júcar River Basin Authority - Confederación Hidrográfica del Júcar (Spanish Ministry of Agriculture, Fishery, Food and Environment) for providing data to develop this study. The authors wish to thank the Spanish Ministry of Economy and Competitiveness for its financial support through the NUTEGES project (CGL2012-34978) and ERAS project (CTM2016-77804-P). We also value the support provided by the European Community's Seventh Framework Program in financing the projects ENHANCE (FP7-ENV-2012, 308438), AGUAMOD (Interreg V-B Sudoe 2016), SWICCA (ECMRWF-Copernicus-FA 2015/C3S_441-LOT1/SMHI) and IMPREX (H2020-WATER-2014-2015, 641811).

\section{References}

Andersson, J.C.M., Pechlivanidis, I.G., Gustafsson, D., Donnelly, C., Arheimer, B., 2015. Key factors for improving large-scale hydrological model performance. Eur. Water 49, 77-88.

Andreu, J., Capilla, J., Sanchís, E., 1996. AQUATOOL, a generalized decision-support system for water-resources planning and operational management. J. Hydrol. 177, 269-291. doi:10.1016/0022-1694(95)02963-X

Bates, B.C., Kundzewicz, Z.W., Wu, S., Palutikof, J.P., 2008. Climate Change and Water, Technical Paper of the Intergovernmental Panel on Climate Change. IPCC Secretariat, Geneva. doi:10.1016/j.jmb.2010.08.039

Bergström, S., Forsman, A., 1973. Development of a conceptual deterministic rainfall-runoff-model. Hydrol. Res. 4.

Confederación Hidrográfica del Júcar, 2015. Plan Hidrológico de la Demarcación Hidrográfica del Júcar. 
Cortekar, J., Bender, S., Brune, M., Groth, M., 2016. Why climate change adaptation in cities needs customised and flexible climate services. Clim. Serv. 4, 42-51. doi:10.1016/j.cliser.2016.11.002

Donnelly, C., Andersson, J.C.M., Arheimer, B., 2016. Using flow signatures and catchment similarities to evaluate the E-HYPE multi-basin model across Europe. Hydrol. Sci. J. 6667, 255-273. doi:10.1080/02626667.2015.1027710

Estrela, T., Pérez-Martín, M.A., Vargas, E., 2012. Impacts of climate change on water resources in Spain. Hydrol. Sci. J. 57, 1154-1167. doi:10.1080/02626667.2012.702213

European Commission, 2015. A European research and innovation Roadmap for Climate Services. Publications Office of the European Union, Luxembourg.

Garrote, L., 2009. Cambio climático: Impactos sobre los recursos hídricos y la disponibilidad del agua, in: Jornadas Sobre Las Repercusiones Del Cambio Climático En La Planificación Y Gestión de Los Recursos Hídricos. Universitat Politècnica de València.

Gil, M., Garrido, A., Gómez-Ramos, A., 2011. Economic analysis of drought risk: An application for irrigated agriculture in Spain. Agric. Water Manag. 98, 823833. doi:10.1016/j.agwat.2010.12.008

Hargreaves, G.H., Samani, Z.A., 1985. Reference crop evapotranspiration from temperature. Appl. Eng. Agric. 1 (2), 96-99.

Haro, D., Solera, A., Paredes, J., Andreu, J., 2014. Methodology for drought risk assessment in within-year regulated reservoir systems. Application to the Orbigo River system (Spain). Water Resour. Manag. 28, 3801-3814. doi:10.1007/s11269-014-0710-3

Herrera, S., Gutiérrez, J.M., Ancell, R., Pons, M.R., Frías, M.D., Fernández, J., 2012. Development and analysis of a 50-year high-resolution daily gridded precipitation dataset over Spain (Spain02). Int. J. Climatol. 32, 74-85. doi:10.1002/joc.2256

Hundecha, Y., Arheimer, B., Donnelly, C., Pechlivanidis, I., 2016. A regional parameter estimation scheme for a pan-European multi-basin model. J. Hydrol. Reg. Stud. 6, 90-111. doi:10.1016/j.ejrh.2016.04.002

IPCC, 2014. Summary for Policymakers, Climate Change 2014: Synthesis Report. Contribution of Working Groups I, II and III to the Fifth Assessment Report of 
the Intergovernmental Panel on Climate Change. doi:10.1017/CBO9781107415324

Kjellström, E., Bärring, L., Nikulin, G., Nilsson, C., Persson, G., Strandberg, G., 2016. Production and use of regional climate model projections. A Swedish perspective on building climate services. Clim. Serv. 2-3, 15-29. doi:10.1016/j.cliser.2016.06.004

Macian-Sorribes, H., Pulido-Velazquez, M., 2017. Integrating Historical Operating Decisions and Expert Criteria into a DSS for the Management of a Multireservoir System. J. Water Resour. Plan. Manag. 143. doi:10.1061/(ASCE)WR.1943-5452.0000712

MAGRAMA (Ministerio de Agricultura Alimentación y Medio Ambiente), 2016. Real Decreto 1/2016, de 8 de enero, por el que se aprueba la revisión de los Planes Hidrológicos de las demarcaciones hidrográficas del Cantábrico Occidental, Guadalquivir, Ceuta, Melilla, Segura y Júcar, y de la parte española de las demarcaciones hidrog.

MAGRAMA (Ministerio de Agricultura Alimentación y Medio Ambiente), 2008. Instrucción de Planificación Hidrológica. ORDEN ARM/2656/2008, de 10 de septiembre, por la que se aprueba la instrucción de planificación hidrológica.

Marcos-Garcia, P., Pulido-Velazquez, M., 2017. Cambio climático y planificación hidrológica: ¿es adecuado asumir un porcentaje único de reducción de aportaciones para toda la demarcación? Ing. del agua 21, 35. doi:10.4995/ia.2017.6361

Merino, J.M., 2012. Evaluación del recurso hídrico en la cuenca del río Júcar (España) mediante la aplicación de modelos semiagregados precipitaciónescorrentía. Universitat Plitècnica de València.

MMA (Ministerio de Medio Ambiente), 2005. Informe Evaluación Preliminar General de los Impactos en España por Efectos del Cambio Climático.

Paredes-Arquiola, J., Solera, A., Andreu, J., Lerma, N., 2012. Manual técnico de la herramienta EVALHID para la evaluación de recursos hídricos.

Pedro-Monzonís, M., Jiménez-Fernández, P., Solera, A., Jiménez-Gavilán, P., 2016. The use of AQUATOOL DSS applied to the System of Environmental- Economic Accounting for Water (SEEAW). J. Hydrol. 533, 1-14. doi:10.1016/j.jhydrol.2015.11.034 
Pérez-Martín, M., Thurston, W., Estrela, T., del Amo, P., 2013. Cambio en las series hidrológicas de los últimos 30 años y sus causas. El efecto 80, in: III Jornadas de Ingeniería Del Agua (JIA 2013). La Protección Contra Los Riesgos Hídricos. Valencia, Spain, pp. 527-534.

Pulido-Velazquez, D., Garrote, L., Andreu, J., Martin-Carrasco, F.J., Iglesias, A., 2011. A methodology to diagnose the effect of climate change and to identify adaptive strategies to reduce its impacts in conjunctive-use systems at basin scale. J. Hydrol. 405, 110-122. doi:10.1016/j.jhydrol.2011.05.014

Salas, J.D., Delleur, J.W., Yevjevich, V.M., Lane, W.L., 1980. Applied Modeling of Hydrologic Time Series. Water Resour. Publ. Littleton, Color. USA.

Sánchez-Quispe, S., Andreu, J., Solera, A., 2001. Gestión de Recursos Hídricos con Decisiones Basadas en Estimación del Riesgo. Universitat Politècnica de València.

Solera, A., Pedro-Monzonís, M., Andreu, J., Estrela, T., n.d. Analysing hydropower production in stressed river basins within the SEEA-W approach. The Júcar River case. Hydrol. Res.

Teutschbein, C., Seibert, J., 2012. Bias correction of regional climate model simulations for hydrological climate-change impact studies: Review and evaluation of different methods. J. Hydrol. 456-457, 12-29. doi:10.1016/j.jhydrol.2012.05.052

van den Hurk, B., Bouwer, L.M., Buontempo, C., Dscher, R., Ercin, E., Hananel, C., Hunink, J.E., Kjellstrom, E., Klein, B., Manez, M., Pappenberger, F., Pouget, L., Ramos, M.H., Ward, P.J., Weerts, A.H., Wijngaard, J.B., 2016. Improving predictions and management of hydrological extremes through climate services. Clim. Serv. 1, 6-11. doi:10.1016/j.cliser.2016.01.001

van Vliet, M., Donnelly, C., Strömbäck, L., Capell, R., Ludwig, F., 2015. European scale climate information services for water use sectors. J. Hydrol. 528, 503513. doi:10.1016/j.jhydrol.2015.06.060

Vargas-Amelin, E., Pindado, P., 2014. The challenge of climate change in Spain: Water resources, agriculture and land. J. Hydrol. 518, 243-249. doi:10.1016/j.jhydrol.2013.11.035 


\subsection{Análisis de la incertidumbre de las proyecciones climáticas en relación a las aportaciones históricas en la Cuenca del Júcar}

Este artículo se centra en la evaluación del impacto del cambio climático sobre las aportaciones futuras y la incertidumbre asociada a ellas, ya que esta es inherente a las proyecciones climáticas y se puede incrementar dependiendo de las decisiones tomadas en su manejo durante todo el proceso de evaluación. También se trató de reducirla por medio de ajustes en los datos iniciales, la corrección del sesgo y otros aspectos que se detallan más adelante.

En este caso, se desarrolló una metodología muy sencilla que se puede considerar como una mejora de la primera parte del método de integración de proyecciones climáticas en el proceso de planificación de los recursos hídricos desarrollada en Suárez-Almiñana et al., (2017).

Como se puede observar en la Fig. 10, se parte de variables meteorológicas ( $\mathrm{P}$ y $\mathrm{T}$ ) procedentes de las proyecciones climáticas, cuyos datos se dividen en un periodo de referencia y periodos futuros. El periodo de referencia se compara con los datos observados de las mismas variables y si no se ajustan se procede a una corrección del sesgo que seguidamente se extenderá a los periodos futuros. En el siguiente paso, estos datos corregidos de ambos periodos se introducen en un modelo hidrológico (previamente calibrado) para obtener las aportaciones del periodo de referencia y de los periodos futuros, que se compararán entre ellos para evaluar el impacto del cambio climático y obtener una tasa de cambio media en porcentaje. 


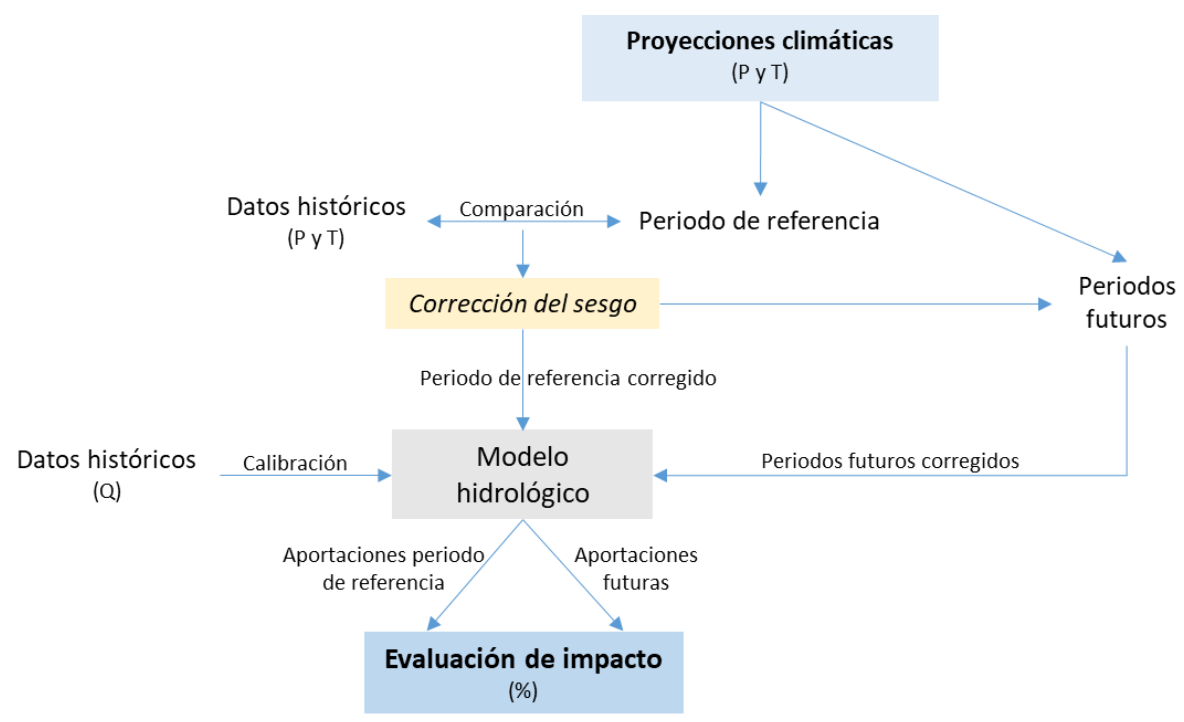

Fig. 10. Metodología para evaluar el impacto del cambio climático en las aportaciones futuras. Fuente: Suárez-Almiñana et al. (2020a).

Este proceso se llevó a cabo en la cuenca del Júcar teniendo en cuenta las siguientes especificaciones:

1- Proyecciones climáticas y datos históricos: En ambos casos se necesitan series de P y T para las 5 subcuencas, además de series de aportaciones históricas en régimen natural proporcionados por la CHJ (periodo 1980-2012). En el caso de las proyecciones climáticas, se seleccionaron datos de P y T de 9 MCR pertenecientes a las SRC 4.5 y 8.5 (Tabla 2), extraídas para cada subcuenca del modelo hidrológico a escala europea E-HYPE. En este caso, los modelos pertenecientes a la SRC 2.6 que estaban incluidos en el artículo anterior se desecharon ya que será imposible alcanzar ese escenario teniendo en cuenta las emisiones y tendencias actuales. Estas proyecciones están divididas en el periodo de referencia 1971-2000 y el periodo futuro 2011-2100, que se divide en 3 periodos de 30 años correspondientes a los horizontes 2020 (periodo 2011-2040, el futuro cercano), 2050 (periodo 2041-2070, el futuro medio) y 2080 (periodo 2071-2100, el futuro lejano). Sin embargo, este último 
periodo se recortó en 2 años debido a falta de datos de dos MCR (ver Tabla 2), por lo que el periodo lejano en este caso es 2071-2098. Además, se trabajó con la media del ensamblado de todos los periodos, como una forma de simplificación y aproximación a la SRC 6.0, la más probable en el futuro según lo indicado en el acuerdo de la cumbre de cambio climático de París de 2015 (Barranco et al., 2018).

Los datos de $\mathrm{P}$ y $\mathrm{T}$ históricos provienen de la base de datos Spain02 en su versión 4 (Herrera et al., 2016), que abarca el periodo 19712010.

2- Ajuste del periodo de referencia: Se decidió recortar el periodo de referencia a 1980-2000 para tener una mejor representación del estado actual de la cuenca, ya que los recursos en este periodo se pueden considerar equivalentes a los del periodo de la serie corta 1980-2012. De este modo, se considera el efecto 80 evitando que el exceso de recursos de los años anteriores se extienda a los periodos futuros en la corrección.

3- Corrección del sesgo: Para corregir las desviaciones entre los datos climáticos y los observados, se corrigió la $\mathrm{P}$ y $\mathrm{T}$ mediante la técnica del mapeo de cuantiles (quantile mapping en inglés), un método robusto y sencillo de aplicar que se basa en la conservación de la media y la desviación estándar del periodo de referencia utilizando la función de distribución.

4- Modelo hidrológico: El modelo HBV se utilizó para obtener las aportaciones del periodo de referencia y de los periodos futuros a partir de las $\mathrm{P}$ y $\mathrm{T}$ corregidas, después de haber sido calibrado exhaustivamente por García-Romero et al., (2019) utilizando dos algoritmos de optimización distintos. Además, para utilizar este modelo, la T corregida se convirtió a ETP mediante el método de Hargreaves (como en el caso anterior). 
5- Evaluación de impacto: El efecto del cambio climático sobre las aportaciones futuras se obtiene mediante una tasa de cambio media (\%) al comparar las aportaciones de cada horizonte futuro con las del periodo de referencia, ambos extraídos del paso anterior. Sin embargo, como no hay una regla preestablecida sobre con qué tipo de datos o periodos históricos hay que comparar los datos futuros, las tasas de cambio se estimaron teniendo en cuenta varios periodos de orígenes distintos (observados y simulados con el HBV) con el fin de ilustrar la dificultad de trabajar en el desarrollo de este tipo de metodologías y la incertidumbre que arrojan sus resultados a la hora de considerarlos en la toma de decisiones en planificación y gestión de SRH. Las aportaciones observadas consideradas en la comparación fueron: la serie larga 1940-2012, la serie corta 19802012 y las series 1971-2000 y 1980-2000. Las aportaciones históricas simuladas con el HBV se corresponden con las procedentes de la simulación efectuada con los datos de P y T históricos (Spain02 v4) y con los del ensamblado (periodo de referencia), ambos para los periodos $1971-2000$ y $1980-2000$.

Los principales resultados indican reducciones (más o menos drásticas) de los recursos hídricos del sistema, sobre todo para finales de siglo. Sin embargo, existe una gran incertidumbre, tanto en la forma correcta de manejar las proyecciones climáticas como a la hora de estimar el impacto del cambio climático en las aportaciones futuras, dependiendo del periodo de referencia escogido, su origen y relación con la situación actual de la cuenca estudiada.

A continuación, se puede ver la versión de autor del siguiente artículo, con el permiso de todos los coautores: 
Suárez-Almiñana, S., Solera, A., Andreu, J., García-Romero, L. (2020). Análisis de incertidumbre de las proyecciones climáticas en relación a las aportaciones históricas en la Cuenca del Júcar. Ingeniería del agua, 24(2), 89-99. https://doi.org/10.4995/la.2020.12149

\section{Análisis de incertidumbre de las proyecciones climáticas en relación a las aportaciones históricas en la cuenca del Júcar}

Uncertainty analysis of climate projections in relation to historical contributions in the Júcar River Basin

Sara Suárez-Almiñana ${ }^{\mathrm{a} 1}$, Abel Solera ${ }^{\mathrm{a} 2}$, Joaquín Andreu ${ }^{\mathrm{a} 3}$ y Liliana GarcíaRomero ${ }^{\text {a4 }}$

anstituto universitario de Ingeniería del Agua y Medio Ambiente (IIAMA), Universitat Politècnica de València (UPV), Camino de Vera s/n, CP: 46022, Valencia (España).

E-mail: ${ }^{1}$ sasual@upv.es,_2asolera@upv.es, ${ }^{3}$ ximoand@upv.es, ${ }^{4}$ ligarro@doctor.upv.es

\section{RESUMEN}

En este estudio se pretende evaluar el efecto del cambio climático en las aportaciones futuras de la Cuenca del Júcar (este de España) y la incertidumbre asociada a ellas, entendiendo como tal la relacionada con la toma de decisiones en el manejo de las proyecciones climáticas durante todo el proceso evaluado.

Para ello se seleccionaron variables meteorológicas de 9 proyecciones climáticas pertenecientes a los escenarios de emisión 4.5 y 8.5, se corrigió el sesgo y se introdujeron en un modelo hidrológico para la simulación de 
caudales. Finalmente, se evaluó el impacto mediante la comparación de los caudales futuros con el periodo histórico.

Dependiendo de los datos históricos que manejemos, el cambio de los caudales futuros puede oscilar de media entre $-8 \%$ y $-28 \%$ para final de siglo. Sin embargo, si se tiene en cuenta la posibilidad de comparar con un periodo que represente la situación actual de la cuenca, este cambio se estima entre a un $-8 \%$ y $-13 \%$, permitiendo así obtener conclusiones más concretas sobre el futuro de los recursos hídricos en esta cuenca.

Palabras clave | Cuenca del Júcar; cambio climático; incertidumbre; aportaciones futuras; modelo hidrológico.

\section{ABSTRACT}

The aim of this study is to evaluate the effect of climate change on the future contributions of the Júcar River Basin (eastern Spain) and the uncertainty associated to them, which in this case is referred to that derived from the decision taken in the handling of climate projections during the entire evaluation process.

For this purpose, meteorological variables were selected from 9 Regional Climate Models belonging to the Representative Concentration Pathways 4.5 and 8.5. Then, they were bias corrected and introduced into a hydrological model for the simulation of flows. Finally, the effect of climate change was evaluated by comparing future flows with those of the historical period.

Depending on the historical data we manage, the change in future flows can range from an average of $-8 \%$ to $-28 \%$ by the end of the century. However, if the possibility of comparing them with a period that represents the current situation of the basin is considered, this change is estimated between $-8 \%$ and $-13 \%$, thus allowing more concrete conclusions about the future of water resources in this basin. 
Key words | Júcar River Basin; climate change; uncertainty; future contributions; hydrological model.

\section{INTRODUCCIÓN}

Los estudios sobre los impactos del cambio climático han ido cobrando fuerza en las últimas décadas hasta ser incluidos en la legislación española, como ha ocurrido en el caso de la Instrucción de Planificación Hidrológica (IPH) (MARM, 2008), donde se dice que los Planes Hidrológicos de Cuenca (PHC) se revisen cada 6 años e incluyan el posible efecto del cambio climático sobre los recursos hídricos de cada demarcación hidrográfica, teniendo en cuenta varios horizontes futuros.

Uno de los datos clave para la estimación de los impactos del cambio climático en las cuencas es el escenario hidrológico al que éstas se van a enfrentar en el futuro. Estos datos son aparentemente cada vez más asequibles debido a la mayor disponibilidad e información acerca de proyecciones climáticas proporcionadas por los servicios climáticos. Uno de los más conocidos es CORDEX (Coordinated Regional Climate Downscaling Experiment), una base de datos internacional donde se pueden obtener proyecciones climáticas de todo el mundo y que también dispone de un dominio europeo (EURO-CORDEX). Sin embargo, la cantidad de proyecciones y variables disponibles es ingente, por lo que se han creado algunos portales a nivel europeo que simplifican su búsqueda (p.ej. IS-ENES Climate4Impact) o disponen de una interfaz gráfica en la que se pueden observar los cambios de las variables e indicadores climáticos (en mapas y gráficos) dependiendo de los horizontes futuros y la escala espacial seleccionada (p.ej. EdGE Copernicus Project).

Una mezcla entre estas dos opciones y dedicado a los recursos hídricos es SWICCA (Service for Water Indicatos in Climate Change Adaptation, Copernicus project), un portal desarrollado a escala europea por el SMHI (Swedish Meteorological and Hydrological Institute) junto con otros colaboradores, entre los que se encuentra el IIAMA-UPV (Instituto de 
Ingeniería del Agua y Medio Ambiente de la Universitat Politècnica de València), que dispone de predicciones estacionales y de cambio climático, tanto para descargar como para visualizar a través de mapas y gráficos interactivos. Además, disponen de gran variedad de indicadores relacionados con la cantidad y calidad del agua, el aire, la temperatura y escenarios socioeconómicos. La variedad de escalas espaciales disponibles y la facilidad de descarga en un formato ampliamente utilizado (.xlsx) también son aspectos a tener en cuenta para elegir este tipo de portales.

También hay servicios climáticos regionalizados para España, como la base de datos proporcionada por AEMET (Agencia Estatal de Meteorología) que fue utilizada en el informe del CEDEX (2017) sobre el impacto del cambio climático en los recursos hídricos y sequías en las cuencas más importantes de España. Las proyecciones usadas en este informe provienen de los modelos globales utilizados en el 50 informe de evaluación (AR5) del Panel Intergubernamental de Cambio Climático (IPCC, 2014), uno de los documentos de referencia a nivel mundial, en el que se estima una disminución de precipitaciones y aumento de temperaturas en el sur de Europa.

Además de estos estudios de referencia, también se han publicado varios trabajos y artículos que recogen metodologías de evaluación del impacto del cambio climático en la hidrología y sistemas de recursos hídricos de algunas cuencas españolas, sobre todo en aquellas más problemáticas desde el punto de vista de la escasez hídrica, tal como la Cuenca del Júcar (Hernández, 2007; Marcos-Garcia et al., 2017; SuárezAlmiñana et al., 2017). Esta cuenca fue seleccionada como zona de estudio debido a su gran variabilidad hidrológica, lo que la lleva a hacer frente a sequías recurrentes que duran varios años. Además, si tenemos en cuenta que estos eventos pueden ser más frecuentes e intensos en el futuro (CEDEX, 2017), es de esperar que los problemas de escasez se incrementarán y será necesaria una toma de decisiones temprana guiada por una evaluación de impacto más acertada. 
Sin embargo, en la mayoría de los estudios citados anteriormente, se hace referencia a la gran incertidumbre que llevan asociadas estas proyecciones y los métodos para trabajar con ellas, aunque se intenta disminuir aplicando métodos como la bajada de escala y la corrección del sesgo. A pesar de ser técnicas ampliamente utilizadas también tienen sus detractores y no garantizan la fiabilidad de los resultados, ya que en ciertas zonas (como la mediterránea) la calidad de estos datos no es muy buena y lograr su ajuste resulta complicado (Barranco et al., 2018; Suárez-Almiñana et al., 2017). Además, hay otras fuentes de incertidumbre que se suman en el proceso, como la asociada a los modelos que se utilizan en la zona de estudio (Marcos-Garcia y Pulido-Velazquez, 2017) y la forma de trabajar con las proyecciones climáticas. Aunque lo más extendido en la literatura es trabajar con el ensamblado de los Modelos Climáticos Regionales (MCR) seleccionados, ya sea con la media de todos ellos o la de los pertenecientes a cada Senda Representativa de Concentración (SRC), algunos autores escogen trabajar con un solo modelo o con el conjunto de los que más se aproximen a los datos observados en su periodo de referencia. Sin embargo, no se recomienda trabajar con un solo modelo ya que puede dar lugar a resultados con comportamientos alejados de la realidad (ColladosLara et al., 2018). Todos estos aspectos son abordados en este estudio.

El principal objetivo de este trabajo es poner de manifiesto la incertidumbre asociada al manejo de las proyecciones climáticas mediante la toma de decisiones (acertadas o no) asociadas al proceso de evaluación de impacto de los caudales futuros en la Cuenca del Júcar e intentar reducirla.

Para ello, en el siguiente apartado se presenta la metodología propuesta, prestando atención a cada paso y teniendo en cuenta las características de la zona de estudio. Posteriormente, los resultados y la discusión se ofrecen en un único apartado, finalizando con el capítulo de las conclusiones obtenidas de este análisis. 


\section{MATERIAL Y MÉTODOS}

En este apartado se explica una metodología muy sencilla desarrollada para evaluar el efecto del cambio climático en las aportaciones futuras de la Cuenca del Júcar. Para ello, como se indica en la Figura 1, se necesitan datos de proyecciones climáticas de precipitación $(P)$ y temperatura $(T)$ y de datos históricos (observados), esto con el objetivo de poder comparar un periodo de referencia y analizar si pueden considerarse estadísticamente similares. Si no es así, una corrección del sesgo es aconsejable. En ese caso, se corrige el periodo de referencia de las proyecciones y se extiende a los periodos futuros. Una vez los datos han sido corregidos, se introducen en el modelo hidrológico para obtener tanto las aportaciones del periodo de referencia como las futuras. Por último, para evaluar el posible impacto del cambio climático, se comparan los periodos futuros con el periodo de referencia y se muestra este resultado en forma de porcentaje, dejando ver así la tendencia que siguen los caudales futuros.

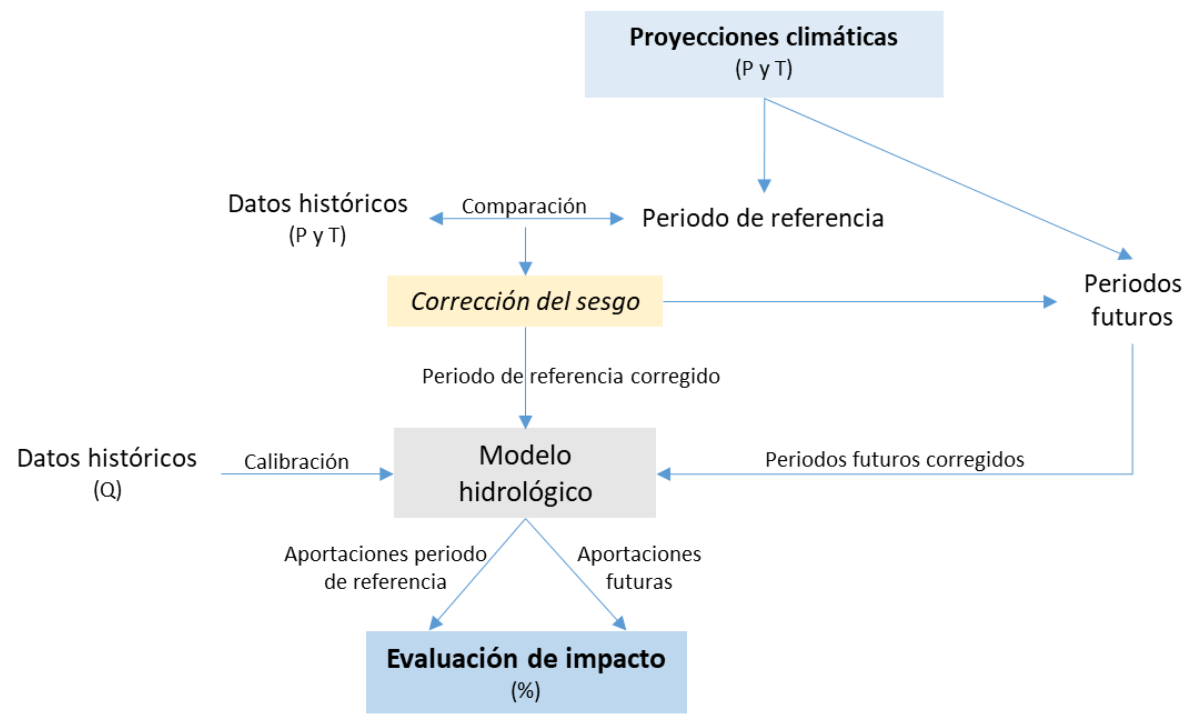

Figura 1 | Metodología para evaluar el impacto del cambio climático en las aportaciones futuras a partir de proyecciones climáticas corregidas e introducidas en un modelo hidrológico. 
Esta metodología se puede considerar como una mejora de la primera parte de la metodología desarrollada por Suárez-Almiñana et al., (2017), en la que se intentó integrar las proyecciones climáticas en el proceso de planificación de los recursos hídricos.

Por otro lado, para la selección del modelo hidrológico se utilizó el módulo EVALHID (Paredes-Arquiola et al., 2012) integrado dentro del software de Sistema de Soporte a la Decisión (SSD) AQUATOOL (Andreu et al., 1996 y 2009). Este programa se caracteriza por integrar varios módulos en una misma herramienta que cubren la mayoría de los problemas relacionados con la evaluación y gestión de los recursos hídricos en sistemas de explotación simples y complejos. También cuenta con una interfaz muy intuitiva y su uso se ha extendido tanto a nivel nacional (incluido en los PHC) como internacional.

Desde la interfaz de inicio se puede acceder a todos los módulos y dibujar el sistema de explotación con todos sus elementos principales (embalses, aportaciones, demandas, retornos, acuíferos, canales, etc.). Aquí es donde está integrado EVALHID, que dispone de varios modelos hidrológicos del tipo precipitación-escorrentía para evaluar la cantidad de recursos hídricos generados en la cuenca. Para más información sobre AQUATOOL SSD y sus módulos se puede visitar su portal de internet oficial: https://aquatool.webs.upv.es/aqt/.

A lo largo de esta sección, se describen de forma detallada los pasos representados en la Figura 1, además de las características de la zona de estudio.

\section{Zona de estudio}

La Cuenca del Júcar (Figura 2) fue elegida como un caso representativo de aplicación, ya que al estar bajo la influencia del clima mediterráneo su variabilidad hidrológica es muy acusada, sumado a la presión a la que se encuentra sometida por la cantidad de demandas a las que tiene que hacer 
frente. Además, debido a estas condiciones hidrológicas, los periodos de sequía son muy recurrentes y duran varios años, como, por ejemplo, las registradas en los periodos 1981-1986, 1992-1995 y 2005-2008.

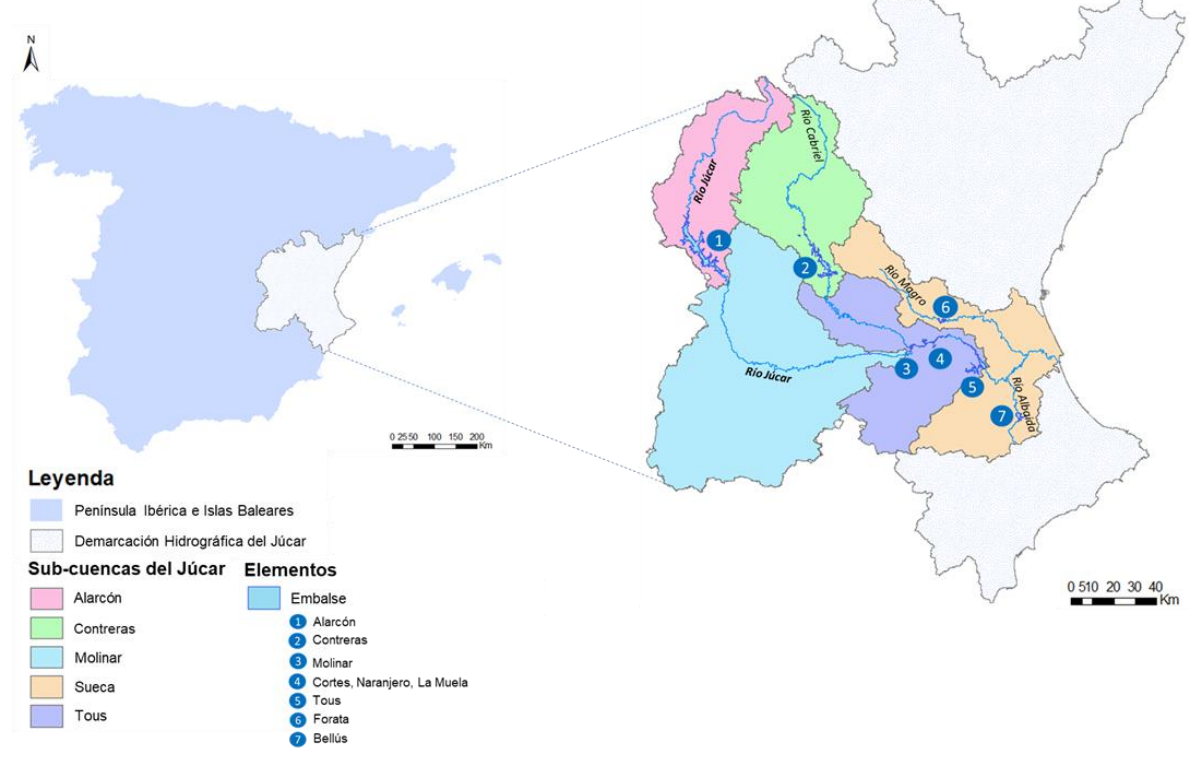

Figura 2 | Ubicación de la Cuenca del Júcar dividida en subcuencas de aportación con sus principales ríos y embalses en la Demarcación Hidrográfica del Júcar y en la Península Ibérica.

Esta cuenca tiene una extensión aproximada de $22187 \mathrm{~km}^{2}$ y es el principal sistema de explotación de la Demarcación Hidrográfica del Júcar (DHJ). Su nombre se debe al río Júcar $(512 \mathrm{~km})$, cuyos principales afluentes son los ríos Cabriel, Albaida y Magro. Este río atraviesa las provincias de Cuenca, Teruel, Albacete y Valencia y finalmente desemboca en el mar Mediterráneo.

Según la CHJ (2015), la P media de esta cuenca es de $475.2 \mathrm{~mm} / \mathrm{año}$, la evapotranspiración potencial (ETP) media de $926.6 \mathrm{~mm} / \mathrm{año}$, la T media de $14.2{ }^{\circ} \mathrm{C}$ y las aportaciones medias se encuentran en torno a los 1605 $\mathrm{hm}^{3} /$ año. Por otro lado, las demandas consuntivas son elevadas (sector agrícola $80 \%$ y sector urbano 15\%), llegando al orden de $1648 \mathrm{hm}^{3}$ (2012) 
(CHJ, 2015). Además, esta cuenca tiene una zona montañosa de interior, una zona intermedia relativamente plana y una zona baja de llanura costera. En estas dos últimas zonas es donde se encuentra la mayor parte del regadío. También es importante destacar que toda esta zona está compuesta por materiales permeables que permiten la infiltración de las precipitaciones a los acuíferos, lo que fomenta la aparición de humedales en la zona costera, como l'Albufera de Valencia que tiene una extensión de 21120 ha, incluyendo una gran extensión de cultivos de arroz.

Por tanto, para hacer frente a estas condiciones tan ajustadas, este sistema cuenta con una importante regulación a través de varios embalses, siendo los más importantes Alarcón $\left(1118 \mathrm{hm}^{3}\right)$, Contreras $\left(852 \mathrm{hm}^{3}\right)$ y Tous $\left(378 \mathrm{hm}^{3}\right.$ ), además de los acuíferos de La Mancha Oriental (parte media de la cuenca) y La Plana de Valencia (parte baja de la cuenca), lo que permite su uso conjunto a la hora de satisfacer las demandas. La Confederación Hidrográfica del Júcar (CHJ) es el organismo que se encarga de la distribución de los recursos hídricos y de la elaboración del Plan Hidrológico de la Demarcación Hidrográfica del Júcar (PHDHJ) (CHJ, 2015) y del Plan Especial de Sequía de la Demarcación Hidrográfica del Júcar (PESDHJ) (CHJ, 2018). En estos planes se encuentran todas las características y formas de proceder frente a fenómenos extremos desde el punto de vista de la gestión y planificación de los recursos hídricos.

\section{Proyecciones climáticas y datos históricos}

Las proyecciones climáticas se obtuvieron del portal europeo SWICCA (http://swicca.eu/), ya que dispone de una selección fiable de MCR para toda Europa y tenían datos suficientes de las variables necesarias para este análisis a escala diaria y de subcuenca (215 km2). Además, la información proporcionada sobre estos datos es muy completa y fácil de entender, así como el manejo de la página web y el formato de descarga (.xlsx).

En este caso se descargaron datos de variables meteorológicas ( $\mathrm{P}$ y $\mathrm{T}$ ) para 5 subcuencas (Figura 2) procedentes de 9 MCR pertenecientes a los 
escenarios de emisiones o SRC 4.5 y 8.5 , cuyo periodo de referencia es 1971-2000 y los periodos futuros se encuentran divididos en intervalos de 30 años entre 2011 y 2100 (Hundecha et al., 2016).

Además, como datos meteorológicos observados o históricos se utilizaron los disponibles en la base de datos Spain02 v4 (Herrera et al., 2016), ya que se han utilizado en otros estudios de esta zona con buenos resultados (Pedro-Monzonís et al., 2016; Suárez-Almiñana et al., 2017; Madrigal et al., 2018; García-Romero et al., 2019). Esta base de datos contiene series de $\mathrm{P}$ y $\mathrm{T}$ a escala diaria y resolución espacial de 0.110 para el periodo 1971-2010, por lo que se obtuvieron datos para los mismos puntos y el mismo periodo de referencia que en el caso anterior con el objetivo de testar su fiabilidad más adelante.

Por otra parte, también son necesarios datos de caudales para la calibración del modelo hidrológico y validar su uso con los datos descritos anteriormente. Estas series de caudales en régimen natural fueron proporcionadas por la $\mathrm{CHJ}$ comprendiendo el periodo 1940-2012 a escala mensual.

\section{Corrección del sesgo}

Para la corrección del sesgo de la P y T se utilizó el método del "quantile mapping", ya que es un método relativamente sencillo de aplicar y con buenos resultados, basado en la función de distribución que intenta conservar la media y la desviación estándar de las series de referencia (Teutschbein \& Seibert, 2012; Collados-Lara et al., 2018).

Para la aplicación del método se utilizó el software estadístico $R$ (https://www.r-project.org/) con el paquete de cálculo "qmap" (Gudmundsson et al., 2012; Gudmundsson, 2016) interpolando los cuartiles empíricos de las variables del período de referencia a escala diaria. Una vez corregido este periodo la corrección se extendió a las series futuras. 


\section{Modelo hidrológico}

El modelo hidrológico seleccionado para obtener las series de caudales fue el modelo precipitación-escorrentía HBV (Bergström, 1995), debido a su buen funcionamiento en esta cuenca después de haber sido calibrado y validado por García-Romero et al., 2019 usando dos algoritmos de optimización distintos y datos de caudales restituidos a régimen natural para el periodo 1980-2007, evitando así el llamado "efecto 80" (PérezMartín et al., 2013; Hernández et al., 2019) y logrando un mejor ajuste con las características actuales de la cuenca. Este fenómeno se caracteriza por un marcado descenso de las precipitaciones y aportaciones a la cuenca a partir de los años 80, lo que hizo que en la IPH (MARM, 2008) se dispusiera una distinción entre la serie larga (1940-2012) y la serie corta (1980-2012). Esta distinción también está contemplada en el PHDHJ, donde se aconseja el uso de la serie corta para temas relacionados con la gestión del agua.

El modelo HBV necesita como datos de entrada series de P y de ETP, por lo que la T corregida se transformó en ETP con el método de Hargreaves (Hargreaves y Samani, 1985). Una vez están listos los datos de entrada, en este caso corregidos, se simulan los caudales del periodo de referencia y de los periodos futuros divididos entre 2011-2040, 2041-2070 y 2071-2098 (acortado 2 años por falta de datos en dos de los modelos).

Después se comparan los caudales de cada periodo futuro con los del periodo de referencia y de ahí se obtiene el efecto del cambio climático sobre las aportaciones futuras, en modo de tasa de cambio estimada en porcentaje.

\section{RESULTADOS Y DISCUSIÓN}

En este apartado se han tomado algunas decisiones para intentar disminuir la incertidumbre asociada al grado de disminución de caudales en el futuro, y así poder formular conclusiones más acertadas sobre un futuro 
incierto que al parecer nos sorprenderá con eventos cada vez más extremos (CEDEX, 2017).

Primero que todo, se optó por reducir el periodo de referencia de los modelos climáticos (1971-2000) a un periodo que representa mejor el estado actual de la cuenca (1980-2000). A pesar de que el periodo propuesto 1980-2000 tiene menos de 30 años (longitud mínima recomendada por la Organización Meteorológica Mundial (Trewin, 2007; Barranco et al., 2018) para garantizar la representatividad estadística de las series), así se evita el exceso de recursos hídricos de los 9 años anteriores debido al efecto 80 explicado anteriormente. De hecho, utilizar datos de años anteriores podría llevar a reducciones más extremas en el futuro o extender este exceso a los caudales futuros mediante la corrección del sesgo de las variables meteorológicas.

En la Figura 3 se muestran las aportaciones (en régimen natural) de los periodos comprendidos entre 1971-2000 y 1980-2000 en la Cuenca del Júcar, además de la serie larga (1940-2012) y la corta (1980-2012) utilizadas en el PHDHJ. Se observa una gran diferencia de recursos hídricos de la serie larga a la corta, estimada en un $21 \%$. Además, el periodo de referencia aportado por los modelos (1971-2000) también supone un $17 \%$ más de recursos hídricos que el de la serie corta. Sin embargo, la serie corta y el periodo $1980-2000$ se pueden considerar equivalentes y representativas de la situación actual.

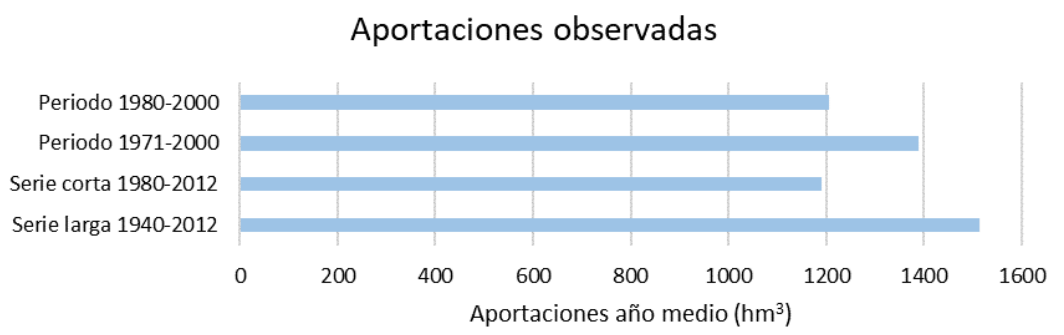

Figura 3 | Aportaciones observadas en régimen natural en la Cuenca del Júcar para varios periodos históricos, la serie larga 1940-2012, la serie corta 1980-2012 y dos periodos de referencia, $1971-2000$ y $1980-2000$. 
Además, hay que tener en cuenta que en este trabajo se optó por trabajar con el conjunto o ensamblado de todos los modelos implicados en el análisis y mostrar los resultados relativos a su media, ya que como se indica en el acuerdo de la cumbre de cambio climático de Paris de 2015, la SRC más probable sería el 6.0 (Barranco et al., 2018), un escenario intermedio entre los dos usados en este estudio. Así, se ofrecen datos intermedios y más próximos a este escenario, simplificando el proceso y evitando los extremos de ambas SRC.

Por lo tanto, una vez acortado el periodo de referencia (1980-2000), se compararon los de ambas bases de datos y se observó cómo los modelos climáticos subestimaban las precipitaciones y sobreestimaban las temperaturas en la mayoría de los puntos seleccionados (Tabla 1), por lo que se procedió a hacer la corrección de sesgo (mediante "quantile mapping") del periodo de referencia y se extrapoló a las series futuras.

Tabla 1 | Precipitaciones $(\mathrm{P}, \mathrm{mm})$ y temperaturas $(\mathrm{T}, \mathrm{O} \mathrm{C})$ medias anuales por subcuenca y de la totalidad de la Cuenca del Júcar, diferenciando entre la serie de datos observados (Spain02), la media del ensamblado sin corregir (Ensamblado) y la media del ensamblado corregido (Ensamblado corregido). En la escala de colores utilizada, los colores rojizos representan los valores bajos de $\mathrm{P}$ y altos en $\mathrm{T}$, mientras que los valores blanquecinos representan lo contrario (valores altos de $\mathrm{P}$ y bajos de $\mathrm{T}$ ).

\begin{tabular}{|c|c|c|c|c|c|c|c|c|}
\hline & \multirow[b]{2}{*}{ Periodo } & \multirow[b]{2}{*}{ Origen } & \multicolumn{5}{|c|}{ Sub-cuencas } & \multirow{2}{*}{ Cuenca del Júcar } \\
\hline & & & Alarcón & Contreras & Molinar & Tous & Sueca & \\
\hline \multirow{3}{*}{ P media anual } & \multirow{3}{*}{$1980-2000$} & Spain02 & 516 & 454 & 332 & 387 & 496 & 437 \\
\hline & & Ensamblado & 367 & 387 & 386 & 405 & 382 & 385 \\
\hline & & Ensamblado corregido & 560 & 507 & 383 & 441 & 555 & 489 \\
\hline \multirow{3}{*}{ T media anual } & \multirow{3}{*}{$1980-2000$} & Spain02 & 13 & 12 & 15 & 16 & 16 & 14 \\
\hline & & Ensamblado & 14 & 15 & 14 & 17 & 19 & 16 \\
\hline & & Ensamblado corregido & 12 & 12 & 14 & 15 & 16 & 14 \\
\hline
\end{tabular}

En la Tabla 1 se puede observar que las mayores subestimaciones de las $P$ por parte del ensamblado se dan en las cuencas de cabecera (Alarcón y Contreras), donde se sitúan los embalses con más capacidad de regulación. Este hecho fue uno de los puntos clave para decidir aplicar la corrección, ya que al transformar los datos sin corregir en caudales la subestimación de los caudales observados no era aceptable, indicando una situación actual 
mucho más crítica de la real en cuanto a disponibilidad de recursos hídricos en la cuenca. Sin embargo, al corregir el ensamblado se obtuvieron datos ligeramente más optimistas para la media anual debido a una sobreestimación de las $\mathrm{P}$ en primavera. A pesar de esto, la corrección se consideró acertada ya que el ajuste del año medio mejoró sustancialmente en cada subcuenca. Por otra parte, la corrección de las $\mathrm{T}$ fue bastante satisfactoria, ya que se redujo la sobreestimación de 2 으 en toda la cuenca.

Después de esta corrección, se estimó la ETP con el método de Hargreaves y las series de P y ETP fueron utilizados como datos de entrada para el modelo hidrológico (HBV).

En la Figura 4 se pueden ver las aportaciones medias del conjunto de los MCR obtenidas con el HBV, tanto para los periodos futuros (ensamblados de 2011-2040, 2041-2070 y 2071-2098) como para los periodos históricos (usando las series de Spain02 y el ensamblado del periodo de referencia 1980-2000).

\section{Aportaciones modelo HBV}

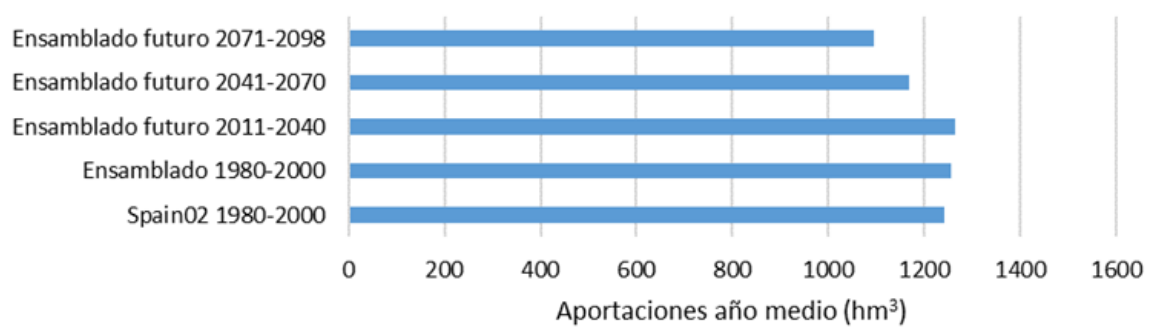

Figura 4 | Aportaciones medias de periodos futuros e históricos obtenidos con el modelo hidrológico HBV a partir de datos de precipitación y ETP provenientes del ensamblado y de Spain02 para la Cuenca del Júcar.

En la figura anterior se observa claramente cómo los recursos hídricos tienden a disminuir a medida que nos acercamos al final del siglo. $\mathrm{Si}$ evaluamos el posible impacto del cambio climático comparando el ensamblado futuro de cada periodo (2011-2040, 2041-2070 y 2071-2098) 
con el de referencia (1980-2000), en el primer periodo se experimenta un incremento del $1 \%$ de media, en el segundo un descenso del $-7 \%$ y en el tercero del $-13 \%$. Esta tendencia decreciente puede suponer un gran reto para la gestión futura de los recursos hídricos en esta cuenca, ya que actualmente la relación entre los recursos generados y las demandas es muy estrecha, cerca del 90\% (CHJ, 2015). Sin embargo, estas reducciones pueden parecer muy pequeñas si tenemos en cuenta otros estudios que se han realizado en esta área, como el del CEDEX (2017), en el que de media (SRC 4.5 y 8.5 ) se estiman unas reducciones de escorrentía del $-7 \%,-18 \%$ y $28 \%$ para toda la $\mathrm{DHJ}$, aunque se indica que los porcentajes de cambio se pueden aplicar a todos sus puntos (Barranco et al., 2018). Además, en el citado estudio los datos no fueron corregidos a pesar de la infravaloración de la $P$ en la vertiente mediterránea y el periodo de referencia utilizado fue 1960-2000 (Barranco et al., 2018), lo que también puede hacer que el contraste entre futuro y pasado sea aún más extremo.

Sin embargo, en este trabajo se modificó el periodo de referencia y se compararon los periodos futuros respecto a su ensamblado con el objetivo de tener una visión del futuro más acertada respecto de las condiciones actuales, pero se pueden barajar otras opciones de comparación que pueden ser (o no) igual de válidas, ya que no hay ninguna regla establecida para estos casos. En principio existen 4 opciones con las que comparar los ensamblados futuros obtenidos: la serie corta observada (1980-2012), la observada del periodo $1980-2000$ y los caudales obtenidos con el modelo HBV (ensamblado 1980-2000 y Spain02 1980-2000). Aunque sigue estando la duda de si la decisión de acortar el periodo de referencia de las proyecciones (1971-2000) es correcta y si se debería tener en cuenta la serie larga como se hace en los PHC. Por esto, en la siguiente figura se pueden ver los posibles efectos del cambio climático (de media) referentes a cada una de estas opciones para esta cuenca. 


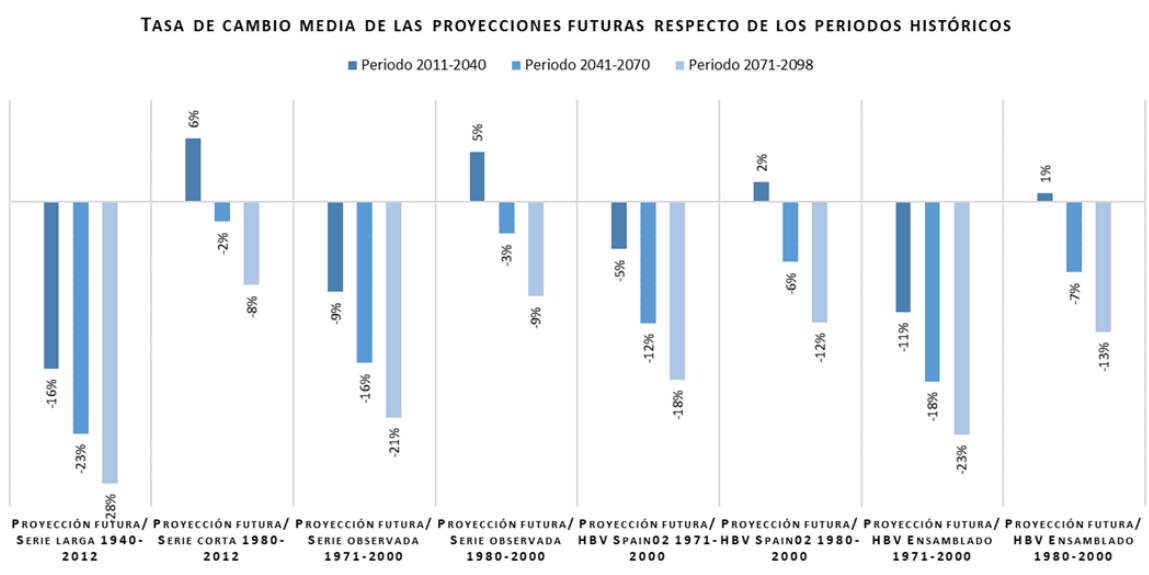

Figura 5 | Tasa de cambio de las aportaciones futuras (periodos 2011-2040, 2041-2070 y 2071-2098) respecto de varios periodos históricos de origen observado (serie larga, serie corta, periodos desde 1971 y 1980 hasta el 2000) y simulados con el HBV (provenientes del ensamblado y Spain02 desde 1971 y 1980 hasta el 2000)

Si comparamos con la serie corta y las referentes al periodo $1980-2000$, el cambio podría estar entre $1 \%$ y $6 \%$ en el periodo 2011-2040 (futuro cercano), entre $-2 \%$ y $-7 \%$ en el periodo $2041-2070$ (futuro medio) y entre $8 \%$ y $-13 \%$ en el periodo $2071-2098$ (futuro lejano). Por otra parte, si solo consideramos la comparación con las series observadas 1980-2000 y 19802012 (serie corta) se obtienen incrementos y/o descensos muy reducidos para la mayor parte del siglo XXI, comenzando a notarse sus efectos a partir del último periodo.

Sin embargo, si no se hubiera tenido en cuenta el efecto 80 acortando el periodo de referencia, los cambios usando las series referentes al periodo 1971-2000 serían de entre $-5 \%$ y - $11 \%$ para el futuro cercano, entre $-12 \%$ y $18 \%$ para el futuro medio y entre $-18 \%$ y $-23 \%$ para el futuro lejano. Además, si comparáramos con la serie larga, estas disminuciones serían aún más drásticas.

Este patrón descendiente de las aportaciones futuras en toda la cuenca (Figura 5) también se mantiene en todas las subcuencas (sobre todo en las 
de cabecera), aunque en las de Molinar y Tous es menos acusado, sobre todo en el primer periodo en el que incluso se estiman algunos incrementos en Tous. Por esta razón, en la Figura 5 se observan ligeros incrementos del primer periodo en algunas de las comparaciones, que podría deberse al incremento en precipitaciones de las zonas medias de la cuenca observado en los últimos años (Hernández Bedolla et al., 2019) y que parece que continuará hasta mediados de siglo.

Por lo tanto, si tratamos los resultados de la Figura 5 en conjunto, las tasas de cambio van desde $-16 \%$ hasta el $6 \%$ en el primer periodo futuro, desde $-23 \%$ hasta $-2 \%$ en el segundo y desde $-28 \%$ hasta $-8 \%$ en el tercero. Parece evidente que ante tanta variabilidad hay que decantarse por una opción, por lo que en este estudio lo hicimos por la que está comparada con las series de caudales del ensamblado 1980-2000 (modelo HBV), ya que es la más lógica y extendida, sumado a que los datos parten de un mismo origen, los modelos climáticos.

Si comparamos estas reducciones medias con las del CEDEX (2017), la que más se aproxima son las del periodo de referencia 1971-2000, lo cual tiene sentido, ya que en ambos casos el periodo es similar y los años anteriores a 1980 les aportan un volumen extra de recursos, siendo normal el mayor contraste entre periodos.

Además, si consideráramos los cambios asociados a cada MCR o SRC, los rangos de los cambios se incrementarían aún más, aumentando así la incertidumbre de los resultados.

También hay que tener en cuenta que el principal objetivo de este tipo de evaluaciones es integrar los datos de caudales o las tasas de cambio en los procesos de planificación de recursos hídricos, por lo que hay que intentar ofrecer resultados cada vez más fiables y con una mayor probabilidad de ocurrencia para una toma de decisiones cada vez más acertada. 
Por lo tanto, para desarrollar una metodología de integración de modelos climáticos en la planificación de recursos hídricos a nivel de cuenca, hay que tener en cuenta muchos factores, tanto a la hora de analizar como a la hora de informar, ya que una vía de trabajo errónea pude llevar a la alarma o a todo lo contrario en periodos clave. Para ello se necesita un conocimiento exhaustivo de las características de la zona de estudio y especificar qué se entiende como situación actual, además del origen del periodo de referencia utilizado y su motivación.

\section{CONCLUSIONES}

En este estudio se ha confirmado una vez más que la posible tendencia futura de los recursos hídricos en una cuenca Mediterránea es decreciente, aunque la incertidumbre asociada a esta afirmación es notable. A pesar de los intentos por reducir esta incertidumbre por medio de ajustes en los datos iniciales al estado actual de la cuenca y la corrección del sesgo de los datos futuros, sigue habiendo dudas razonables sobre la mejor forma de trabajar con las proyecciones climáticas. Sin embargo, a la hora de comparar las aportaciones futuras con las del periodo de referencia se tomó la opción más lógica y extendida, obteniendo una reducción media del $-13 \%$ para finales de siglo, pero hay otras opciones que se pueden contemplar y que añaden más incertidumbre a los resultados. Dependiendo del periodo de referencia que tomemos, las conclusiones sobre los impactos del cambio climático en los recursos hídricos pueden ser más o menos alarmantes, en este caso oscilando entre un $-28 \%$ y un $-8 \%$ de reducción media para final de siglo. Por todo esto, es importante dejar clara la referencia de los cambios, sobre todo si ésta no concuerda con la situación actual de la cuenca, para una correcta toma de decisiones.

Por último, la metodología usada y las decisiones tomadas pueden replicarse fácilmente teniendo en cuenta que todo el proceso de decisión obedece a un profundo conocimiento de la zona de estudio, por lo que su extrapolación a otros casos requiere del conocimiento de expertos. 


\section{AGRADECIMIENTOS}

Los autores agradecen a la Agencia Estatal de Investigación (MINECO) por financiar el proyecto "ERAS" (CTM2016-77804-P), cofinanciado con Fondos FEDER. Además, también valoramos el apoyo de la Comunidad Europea en la financiación de los proyectos IMPREX (H2020-WATER-20142015, 641811) y SWICCA (ECMRWF-Copernicus-FA 2015/ C3S_441LOT1/SMHI).

También es importante nombrar al Programa de Apoyo para la Investigación y Desarrollo (PAID-01-17) de la Universitat Politècnica de València por fomentar y facilitar los contratos de formación de personal investigador.

Finalmente, los autores agradecen a AEMET y a la Universidad de Cantabria (UC) los datos aportados para este trabajo (conjunto de datos Spain02 v4, disponibles en http://www.meteo.unican.es/datasets/spain02).

\section{REFERENCIAS}

Andreu, J., Capilla, J., Sanchís, E. 1996. AQUATOOL, a generalized decision-support system for water-resources planning and operational management. Journal of Hydrology, 177(3-4), 269-291. https://doi.org/10.1016/0022-1694(95)02963$X$

Andreu, J., Ferrer-Polo, J., Pérez, M. A., Solera, A. 2009. Decision support system for drought planning and management in the Jucar river basin, Spain. Procedings of the 18th world IMACS / MODSIM Congress, July 13-17, Cairns, Australia, 3223-3229. http://www.mssanz.org.au/modsim09/13/andreu_a.pdf

Barranco, L. M., Dimas, M., Jiménez, A., Estrada, F. 2018. Nueva evaluación del impacto futuro del cambio climático en los recursos hídricos en España. Ingeniería Civil, 191/2008, 34-55.

Bergström, S. 1995. The HBV Model. In: Computer Models of Watershed Hydrology. Water Resources Publications, Highlands Ranch, Colorado, USA, 443-476. 
CEDEX. 2017. Evaluación del impacto del cambio climático en los recursos hídricos y sequías de España. Informe técnico para Ministerio de Agricultura y Pesca, Alimentación y Medio Ambiente. Madrid, Spain.

CHJ. 2015. Plan Hidrológico de la Demarcación Hidrográfica del Júcar. Memoria ciclo de planificación hidrológica 2015-2021. Ministerio de Agricultura, Alimentación y Medio Ambiente. Valencia, Spain.

CHJ. 2018. Plan Especial de Sequía Demarcación Hidrográfica del Júcar. Ministerio de Agricultura y Pesca, Alimentación y Medio Ambiente. Valencia, Spain.

Collados-Lara, A. J., Pulido-Velazquez, D., Pardo-Igúzquiza, E. 2018. An integrated statistical method to generate potential future climate scenarios to analyse droughts. Water 10, 1224, 1-24. https://doi.org/10.3390/w10091224

García-Romero, L., Paredes-Arquiola, J., Solera, A., Belda, E., Andreu, J., SánchezQuispe, S. T. 2019. Optimization of the multi-start strategy of a direct-search algorithm for the calibration of different rainfall-runoff models for the water resources assessment. Water 11(9), 1-27. https://doi.org/10.3390/w11091876

Gudmundsson, L., Bremnes, J. B., Haugen, J. E., \& Engen-Skaugen, T. 2012. Technical Note: Downscaling RCM precipitation to the station scale using statistical transformations - a comparison of methods. Hydrology and Earth System Sciences, 16(9), 3383-3390. https://www.hydrol-earth-systsci.net/16/3383/2012/

Gudmundsson, L. 2016. qmap: Statistical transformations for post-processing climate model output. R Package Version 1.0-4 https://doi.org/10.5194/hess16-3383-2012.bernexp.

Hargreaves, G.H., Samani, Z.A. 1985. Reference crop evapotranspiration from temperature. Applied Engineering in Agriculture, 1 (2), 96-99.

Hernández Bedolla, J., Solera, A., Paredes Arquiola, J., Roblero Escobar, C. X. 2019. Análisis del cambio en las aportaciones hidrológicas en la cuenca del río Júcar a partir de 1980 y sus causas. Ingeniería Del Agua, 23(2), 141-155. https://doi.org/10.4995/ia.2019.10582

Hernández, L. 2007. Efectos del cambio climático en los sistemas complejos de recursos hídricos. Aplicación a la cuenca del Júcar. Tesis Doctoral, Universitat Politècnica de València, Valencia, Spain. 
Herrera, S., Fernández, J., Gutiérrez, J. M. 2016. Update of the Spain02 gridded observational dataset for EURO-CORDEX evaluation: Assessing the effect of the interpolation methodology. International Journal of Climatology, 36(2), 900-908. https://doi.org/10.1002/joc.4391

Hundecha, Y., Arheimer, B., Donnelly, C., Pechlivanidis, I. 2016. A regional parameter estimation scheme for a pan-European multi-basin model. Journal of Hydrology: Regional Studies, 6, 90-111. https://doi.org/10.1016/j.ejrh.2016.04.002

IPCC. 2014. Climate Change 2014: Synthesis Report. Contribution of Working Groups I, II and III to the Fifth Assessment Report of the Intergovernmental Panel on Climate Change [Core Writing Team, R.K. Pachauri and L.A. Meyer (eds.)]. IPCC, Geneva, Switzerland, 151 pp. https://doi.org/10.1017/CBO9781107415324

Madrigal, J., Solera, A., Suárez-Almiñana, S., Paredes-Arquiola, J., Andreu, J., Sánchez-Quispe, S. T. 2018. Skill assessment of a seasonal forecast model to predict drought events for water resource systems. Journal of Hydrology, 564(February), 574-587. https://doi.org/10.1016/j.jhydrol.2018.07.046

Marcos-Garcia, P., Lopez-Nicolas, A., Pulido-Velazquez, M. 2017. Combined use of relative drought indices to analyze climate change impact on meteorological and hydrological droughts in a Mediterranean basin. Journal of Hydrology, 554, 292-305. https://doi.org/10.1016/j.jhydrol.2017.09.028

Marcos-Garcia, P., \& Pulido-Velazquez, M. (2017). Cambio climático y planificación hidrológica: ¿es adecuado asumir un porcentaje único de reducción de aportaciones para toda la demarcación? Ingeniería Del Agua, 21(1), 35. https://doi.org/10.4995/ia.2017.6361

MARM. 2008. Instrucción de Planificación Hidrológica. ORDEN ARM/2656/2008, de 10 de septiembre, por la que se aprueba la instrucción de planificación hidrológica., 38472-38582.

Paredes-Arquiola, J., Solera, A., Andreu, J., Lerma, N. 2012. Manual técnico de la herramienta EVALHID para la evaluación de recursos hídricos. Universitat Politècnica de València. Valencia, Spain.

Pedro-Monzonís, M., Jiménez-Fernández, P., Solera, A., Jiménez-Gavilán, P. 2016. The use of AQUATOOL DSS applied to the System of Environmental-Economic Accounting for Water (SEEAW). Journal of Hydrology, 533, 1-14. https://doi.org/10.1016/j.jhydrol.2015.11.034 
Pérez-Martín, M., Thurston, W., Estrela, T., del Amo, P. 2013. Cambio en las series hidrológicas de los últimos 30 años y sus causas. El efecto 80 . En las III Jornadas de Ingeniería del Agua (JIA 2013). La protección contra los riesgos hídricos. October 23-24, Valencia, Spain, 527-534.

Suárez-Almiñana, S., Pedro-Monzonís, M., Paredes-Arquiola, J., Andreu, J., Solera, A. 2017. Linking Pan-European data to the local scale for decision making for global change and water scarcity within water resources planning and management. Science of the Total Environment, 603-604, 126-139. https://doi.org/10.1016/j.scitotenv.2017.05.259

Teutschbein, C., Seibert, J. 2012. Bias correction of regional climate model simulations for hydrological climate-change impact studies: Review and evaluation of different methods. Journal of Hydrology, 456-457, 12-29. https://doi.org/10.1016/j.jhydrol.2012.05.052

Trewin, B. C. 2007. Función de las normales climatológicas en un clima cambiante. (O. Baddour \& H. Kontongomde, Eds.), Organización Meteorológica Mundial (Vol. 43). Ginebra. 


\subsection{Evaluación del riesgo en la planificación hidrológica de la cuenca del Júcar bajo la influencia del cambio climático}

En este artículo se presentó una metodología de evaluación del riesgo de sequía a largo plazo, basada en la desarrollada por Suárez-Almiñana et al., (2017) incluyendo varias mejoras. Estas mejoras están relacionadas con la corrección del sesgo, la inclusión de un modelo determinístico y la posibilidad de extraer más resultados (probabilísticos y determinísticos) para horizontes futuros. Además, se trata de una metodología general en la que se toman decisiones en función de las características de la cuenca a la que se adapte.

Este método (Fig. 11) consta de tres partes principales compuestas por la caracterización de las aportaciones, un enfoque determinista, y un enfoque probabilístico. De estas tres secciones, se pueden extraer respectivamente, los impactos en las aportaciones futuras, el volumen futuro almacenado en el sistema y un indicador del riesgo de sequía.

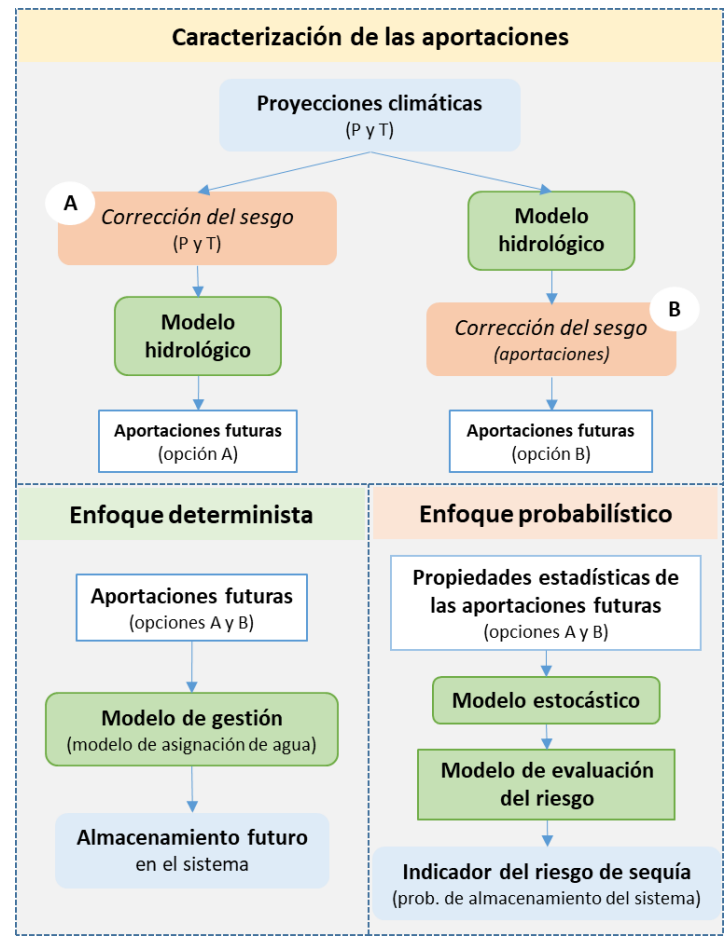

Fig. 11. Metodología de integración de proyecciones climáticas en la gestión y planificación hidrológica mediante la caracterización de las aportaciones y enfoques determinista y probabilísticos. Modificado de (Suárez-Almiñana et al., 2020b). 
A continuación, se detalla cada una de las secciones en las que se divide esta metodología:

1- Caracterización de las aportaciones: Los datos de inicio son series de $\mathrm{P}$ y $\mathrm{T}$ procedentes de proyecciones climáticas. Estos datos constan de un periodo de referencia y otro futuro, el de referencia se compara con datos históricos locales para analizar su ajuste y si no es satisfactorio se aconseja aplicar una corrección de sesgo. En este punto, hay dos opciones, corregir las variables meteorológicas antes de introducirlas en el modelo hidrológico (opción A), o corregir las aportaciones obtenidas después de simular el modelo hidrológico a partir de series no corregidas de $\mathrm{P}$ y T (opción B). En ambos casos, las correcciones se extienden a los periodos futuros. Además, el modelo hidrológico tiene que representar estrictamente las características del caso de estudio, lo que implica una buena calibración.

Con estas dos opciones se ofrecen dos formas de trabajar con los mismos datos para garantizar unos resultados más fiables al final del proceso. También, al comparar el periodo futuro con el periodo de referencia (medias del ensamblado) se puede estimar el impacto del cambio climático en las aportaciones futuras mediante una tasa de cambio media expresada en porcentaje (Suárez-Almiñana et al., 2020a).

2- Enfoque determinista: Seguidamente, el ensamblado de las aportaciones futuras proveniente de las opciones anteriores, ambas por separado o la que se considere más adecuada para seguir con el proceso, son introducidas en un modelo de gestión para simular la asignación de agua futura en el sistema. De esta simulación se puede obtener el volumen futuro almacenado en el sistema, teniendo en cuenta el ensamblado, su media y las medias de cada periodo futuro. 
3- Enfoque probabilístico: En este apartado, las propiedades estadísticas de las aportaciones provenientes de la caracterización (una o ambas opciones por separado) se utilizan en el modelo estocástico para generar múltiples series equiprobables para introducirlas en el modelo de evaluación del riesgo. En este modelo, se simula la gestión del sistema tantas veces como series se hayan generado y los resultados de tratan de forma estadística para condensarlos en un indicador probabilístico de riesgo de sequía relacionado con la probabilidad de volumen embalsado en el sistema.

Este método también se adaptó a la cuenca del Júcar teniendo en cuenta las características indicadas en los siguientes puntos:

1- Proyecciones climáticas y datos históricos: Se utilizaron los mismos datos que en la sección anterior.

2- Ajuste del periodo de referencia: El periodo de referencia (19712000) se recortó al 1980-2000, como en la sección anterior.

3- Corrección del sesgo: La técnica del mapeo de cuantiles se utilizó para corregir las series de variables meteorológicas ( $P$ y $T$ ) en la opción A y las de las variables hidrológicas (aportaciones) en la opción B. En ambos casos, la corrección se aplica al periodo de referencia utilizando los datos observados y seguidamente se extiende a los periodos futuros.

4- Modelo hidrológico: En ambas opciones se utilizó el modelo HBV descrito en la sección anterior para generar aportaciones futuras y así llevar a cabo la gestión del sistema y la evaluación del riesgo (siguientes pasos).

En la opción A, las series corregidas de P y ETP (aplicación del método Hargreaves a la T corregida) se introdujeron en el modelo 
para obtener las aportaciones, tanto del periodo de referencia como de los periodos futuros. Sin embargo, en la opción B, se introdujeron las series sin corregir de las mismas variables, con el objetivo de corregir posteriormente las aportaciones producto de esta simulación. En ambos casos, se simuló el modelo teniendo en cuenta todo el periodo futuro (2011-2098) para conservar las condiciones iniciales de cada periodo y sus tendencias.

Una vez obtenidas las aportaciones, es posible extraer la tasa de cambio media para las aportaciones futuras al comparar la media del ensamblado de cada periodo futuro con la del periodo de referencia.

5- Modelo de gestión: Este es un modelo de asignación del agua de la cuenca del Júcar en el que se integraron todos los elementos necesarios para su gestión, así como las reglas de operación actuales.

Las aportaciones futuras obtenidas en el apartado anterior (ensamblados de las opciones A y B por separado) se introdujeron en este modelo para simular la gestión del sistema y obtener una estimación determinística de los recursos futuros almacenados en el sistema.

6- Modelo estocástico: Un modelo multivariado auto-regresivo de primer orden $A R(1)$ se utilizó para la generación de múltiples series de aportaciones previo al análisis del riesgo. Como este modelo fue calibrado para el periodo histórico 1980-2012, se corrigió con las propiedades estadísticas de las aportaciones futuras obtenidas en el punto 4 , en este caso teniendo en cuenta su media y desviación típica. Una vez corregido, se generaron 1000 series de 30 años por miembro del ensamblado y periodo futuro (cercano, medio y lejano) para cada una de las opciones (A y B). 
7- Modelo de evaluación del riesgo: El modelo de gestión se utilizó para simular para cada una de las series generadas en el paso anterior en la metodología de Monte-Carlo. Los resultados de la gestión se trataron estadísticamente para extraer un indicador probabilístico del riesgo de sequía que informa sobre la evolución de los recursos hídricos almacenados en el sistema para el ensamblado de cada periodo futuro. En este punto también se obtienen probabilidades de excedencia de dicho almacenamiento en meses clave.

Respecto a los impactos del cambio futuro en las aportaciones futuras, se han estimado menores aportaciones conforme nos acercamos a finales de siglo. En este sentido, no solo tiene importancia el cuanto y el cuándo, sino también el dónde, ya que se han estimado reducciones preocupantes en las cuencas de cabecera, lo que puede significar un gran desafío para la gestión del sistema ya que los embalses más importantes se localizan en esta zona. Además, las reducciones en las zonas medias y bajas de la cuenca también pueden significar menores infiltraciones a los acuíferos y mayores demandas en las temporadas de riego.

Los volúmenes almacenados en el futuro difieren entre las opciones $\mathrm{A}$ y $B$, siendo los de esta última más pesimistas al pronosticar varios y recurrentes periodos de sequía intensa a partir de mediados de siglo. Sin embargo, en ambos casos el rango ocupado por el ensamblado es bastante amplio, ocupando casi la totalidad de la capacidad estimada para el sistema, lo que indica una elevada incertidumbre futura.

En los indicadores de riesgo de sequía de ambas opciones se observaron probabilidades muy similares en todos los periodos estudiados. $Y$, salvo en el primer periodo, donde se estiman altas probabilidades de tener almacenados menos de la mitad de los recursos totales del sistema, los rangos de probabilidades cubiertos por el ensamblado son muy amplios, lo que indica una gran incertidumbre a partir de mediados de siglo. 
Por lo tanto, el desarrollo de esta metodología se puede entender como el primer paso para transformar la información facilitada por los servicios climáticos en información útil para el proceso de toma de decisiones en la gestión y planificación hidrológica, ya que se trata de una metodología robusta y adaptable a cuencas complejas, como la del Júcar. Los resultados en esta cuenca son preocupantes, ya que todo indica que se enfrentará a importantes reducciones de los recursos hídricos en el futuro, un escenario insostenible y difícil de sobrellevar para los gestores de la cuenca. Sin embargo, los resultados más allá de mitad de siglo poseen mucha incertidumbre (gran dispersión de los MCR), lo que indica la necesidad de una mejora de las proyecciones climáticas para esta zona, además de posibles ajustes en la metodología propuesta.

A continuación, se puede ver la versión de autor del siguiente artículo, con el permiso de todos los coautores:

Suárez-Almiñana, S., Solera, A., Madrigal, J., Andreu, J., ParedesArquiola, J. (2020): Risk assessment in water resources planning under climate change at the Júcar River basin, Hydrology and Earth System Sciences, 24, 5297-5315, https://doi.org/10.5194/hess-24-5297-2020

\section{Risk assessment in water resources planning under climate change at the Júcar River Basin}

Sara Suárez-Almiñana ${ }^{1}$, Abel Solera ${ }^{1}$, Jaime Madrigal $^{1}$, Joaquín Andreu ${ }^{1}$, Javier Paredes-Arquiola ${ }^{1}$

${ }^{1}$ Research Institute of Water and Environmental Engineering (IIAMA), Universitat Politècnica de València, 46022, Valencia, Spain

Correspondence to: Sara Suárez-Almiñana (sasual@upv.es) 
Abstract. Climate change and its possible effects on water resources has become an increasingly near threat. Therefore, the study of these impacts in highly regulated systems and those suffering extreme events is essential to deal with them effectively.

This study responds to the need for an effective method to integrate climate change projections into water planning and management analysis in order to guide the decision-making taking into account drought risk assessments. Therefore, this document presents a general and adaptive methodology based on a modelling chain and correction processes, whose main outcomes are the impacts on future natural inflows, a drought risk indicator and the simulation of future water storage in the water resources system (WRS).

This method was applied in the Júcar River Basin (JRB) due to its complexity and the multiannual drought events it suffers recurrently. The results showed a worrying decrease in future inflows, as well as a high probability $(\approx 80 \%)$ of being under $50 \%$ of total capacity of the WRS in the near future. However, the uncertainty of the results was considerable from the mid-century onwards, indicating that the skill of climate projections needs to be improved in order to obtain more reliable results. Consequently, this paper also highlights the difficulties of developing this type of method, taking partial decisions to adapt them as far as possible to the basin in an attempt to obtain clearer conclusions on climate change impact assessments.

Despite the high uncertainty, the results of the JRB call for action and the tool developed can be considered as a feasible and robust method to facilitate and support decision-making in complex basins for future water planning and management. 


\section{Introduction}

The studies related to the possible effects of climate change on social, environmental, and economic frameworks have increased exponentially in recent decades. The main reason for this increase is the need to improve the adaptability of society and the capacity to manage risk, which was recognized by governments, scientists, and decision-makers at the World Climate Conference in 2009 and led to the creation of the Global Framework for Climate Services (GFCS) (Hewitt et al., 2013).

In fact, climate services have evolved over time to reach the wide variety of data that are available today, at the global (e.g., CORDEX - Coordinated Regional Climate Downscaling Experiment, https://www.cordex.org/), continental (e.g., SWICCA - Service for Water Indicators in Climate Change Adaptation, http://swicca.eu/) or national level (e.g., AEMET - State Meteorological Agency in Spain, http://www.aemet.es).

Normally, seasonal forecasts and climate projections are freely accessible through Internet portals, but the massive amount of data provided needs advanced knowledge for their extraction. Therefore, some portals at continental and national level facilitate the process of selecting models and variables by filtering them according to the fitting to the area and the user's needs (meteorological and hydrological variables, indicators, graphs, tables, etc.).

According to van den Hurk et al. (2016), climate services are essential to boost innovation in the water sector and increase its capacity to adapt to climate change. Hence, the massive amount of data provided presents the opportunity to develop new tools or to improve the current ones incorporating climate projections in water management to extract useful information adapted to specific sectoral needs (Hewitt et al., 2013). That is exactly what we aim to do in this study, proposing a general methodology inspired by the work of Suárez-Almiñana et al. (2017) to integrate climate projections into the decision process throughout a model chain for water 
management and drought risk assessments, where the future impacts on inflows and water resources are evaluated.

However, developing new methods is not easy, especially if it is for a long-term range, since anticipating responses to extreme events in a solid decision-making context for a distant future is challenging (van den Hurk et al., 2016). In addition, van den Hurk et al., (2018) ensure that there is a gap between the spatial and temporal scales of the models versus the scales needed in applications and also highlight the need to tailor climate results to real-world applications. These issues, among many others, may be the reason why so little climate action is taking place despite the wider knowledge of climate change (Naustdalslid, 2011).

Therefore, it seems that some issues need to be resolved in order to move forward in the process of developing these new methods. The selection of projections and how to handle them correctly are part of these issues, since the inherent uncertainty of projections normally determines its use in practice (Lemos and Rood, 2010). In this sense, some authors recommend working with the ensemble (Stagl and Hattermann, 2015), since increasing the number of ensemble members (EM) reduces the sampling uncertainty (Collados-Lara et al., 2018; Thompson et al., 2017). Another option is differentiating between the Representative Concentration Pathways (RCPs) implied in the study (Barranco et al., 2018; Marcos-Garcia et al., 2017) to consider the impacts related to the emission scenarios. However, working with only one ensemble member is not advisable, since the results can lead to erroneous conclusions due to the extreme values (Collados-Lara et al., 2018).

The need to reduce the uncertainty or increase the skill of these data is also a recurrent topic, but the dispersion of the EMs is a fact across the world (Stagl and Hattermann, 2016; Chatterjee et al., 2018; SuárezAlmiñana et al., 2020), which would hamper the impact simulations (Teutschbein and Seibert, 2013) and influence the reliability of final results, making decision-makers reluctant to consider these data for water 
management. The application of correction processes might be a solution to this problem, but these corrections may not provide a satisfactory physical justification (Ehret et al., 2012; Suárez-Almiñana et al., 2017) and it makes their inclusion in real-world applications more difficult.

Here is where the main improvement of the proposed methodology is focussed, the characterisation of future inflows, where correction and adjustment processes are applied to the ensemble in order to strictly adapt it to the case study in an attempt to reduce the uncertainty of simulated flows. Consequently, this step is also related to the proper calibration of the models involved in the modelling chain, which makes the complementation of management and risk assessments easier. All these efforts are related to the aim of obtaining more reliable results for decision-makers to trust these types of tools and to integrate them in the River Basin Management Plans (RBMPs).

In fact, our study was focused in the east of Spain, the Júcar River Basin (JRB), where the inclusion of climate change assessments in the RBMP is mandatory, but it is not considered in the decision-making yet.

Thus, the need for an effective methodology that integrates the climate change projections to guide the decision-making is notable in this country and probably in many others. For this reason, the main objective of this study is to provide an answer for some of the above-mentioned issues, for which an adaptive tool is developed to support and help basin managers to cope with future extreme events such as droughts, which may be more frequent and intense in the future (CEDEX, 2017; Marcos-Garcia et al., 2017). In addition, testing this tool in the JRB may be challenging, since this basin is heavily regulated and has a high hydrological variability that leads to recurrent droughts of several years. Hence, the scarcity problems are expected to increase and early decision-making guided by a more accurate impact assessment will be needed. 
To this end, we rely on different modelling approaches that can be found in the next sections. First, the features of the case study are presented in Section 2. The general methodology is then described in Section 3 in a simplified manner, followed by its adaptation to the JRB, where the climatic and local data, the methods of adjustment and correction and the characteristics of the modelling chain are specified. The hydrological model is the first in this chain and it is part of the characterization of natural inflows. This model is followed by the management model (deterministic approach) and the stochastic and risk assessment models (probabilistic approach). After that, Section 4 introduces the results of the approaches mentioned above. First, the adjustment and correction of the data (meteorological or hydrological) and the outputs of these processes after the hydrological model are presented, allowing the impacts on future water resources to be estimated. Next, the future water storage in the system and the drought risk indicator are presented as part of the deterministic and probabilistic approaches, respectively. Finally, the discussion section justifies all the partial decisions taken during the process and the conclusion section summarizes the main outcomes of this study.

\section{Case study: The Júcar River Basin}

The Júcar River Basin is located in the eastern part of the Iberian Peninsula (Fig. 1) and it is the main water resources system (WRS) of the Júcar River Basin District (JRBD). Its extension is around 22,187 $\mathrm{km}^{2}$ and the average volume of water resources generated is around $1,605 \mathrm{hm}^{3} /$ year (CHJ, 2015). The river is $512 \mathrm{~km}$ long and the main tributaries are the Cabriel, Albaida, and Magro rivers.

This is a semi-arid area due to the influence of the Mediterranean climate. The average precipitation is $475.2 \mathrm{~mm}$ /year, the average potential evapotranspiration (PET) is $926.6 \mathrm{~mm} / \mathrm{year}$ and the annual average temperature is between $14-16.5{ }^{\circ} \mathrm{C}$, reaching the maximum in summer (June, July, and August), the dry season. Moreover, the high hydrological 
variability of this basin leads to recurrent multiannual droughts with some periods of floods in between.

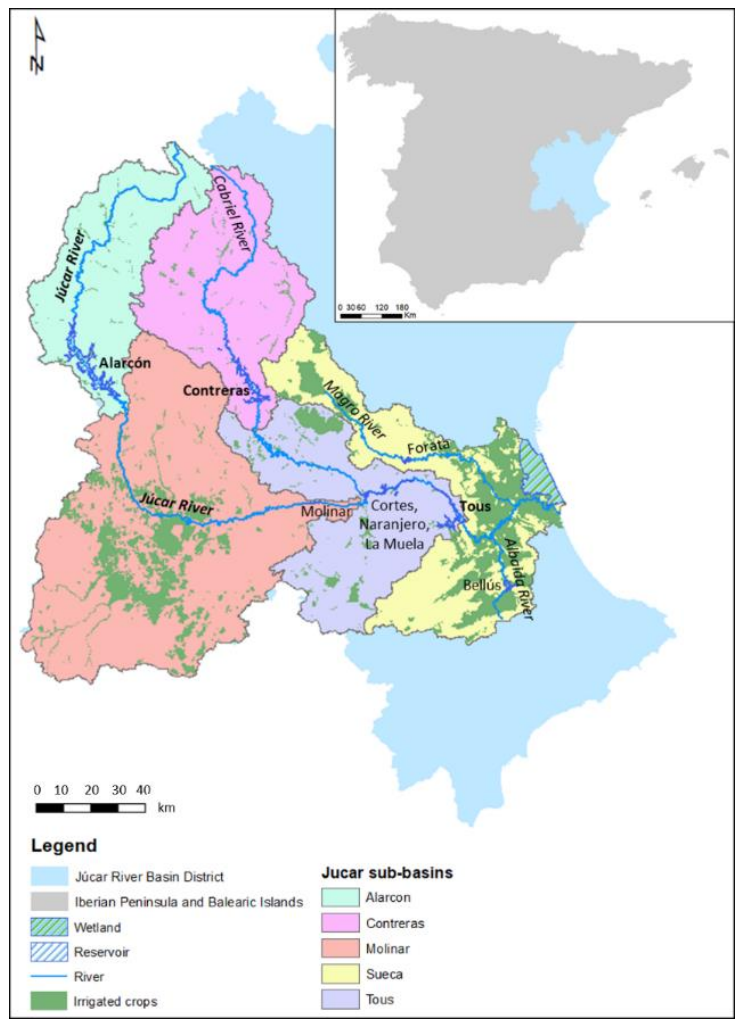

Figure 1. Location of the Júcar River Basin District and the Júcar River Basin (divided into sub-basins) in Spain. Source: Confederación Hidrográfica del Júcar $(\mathrm{CH}$, www.chj.es) and Instituto Geológico y Minero de España (IGME, http://www.igme.es/).
In addition to these hydrological features, consumptive demands are high $\left(1,648.39 \mathrm{hm}^{3} /\right.$ year $)$ (CHJ, 2015). The irrigated agriculture accounts for nearly $80 \%$ of water demand and other sectors (including urban supply) account for $20 \%$.

The inland part of the basin is a mountainous area and the middle basin is a relatively flat area (high plain) that currently supports the major part of the irrigated agriculture $(\approx$ 100,000 ha). The lower basin lies in the coastal plain, which supports traditionally irrigated areas as well as more recent

irrigated areas. There are permeable materials that allow rainfall infiltration into the aquifers of La Mancha Oriental (middle part of the basin, Molinar) and La Plana de Valencia (lower basin, Sueca), where groundwater is abstracted. In addition, there is an important wetland in the coastal area called l'Albufera de Valencia, which has an extension of 21,120 ha including a vast extension of rice crops. 
Therefore, this combination of high water demand and hydrological variability forces adaptation by different management strategies, as water storage infrastructures, conjunctive use of surface and ground waters, and institutional and legal developments.

Thus, this WRS is highly regulated, having several reservoirs, the more important are Alarcon $\left(1,112 \mathrm{hm}^{3}\right)$ and Contreras $\left(852 \mathrm{hm}^{3}\right)$, which operate on a multi-year scale. On the other hand, Tous reservoir $\left(314 \mathrm{hm}^{3}\right)$ operates on an annual basis, storing the releases from upstream reservoirs and the inflows of the middle basin to supply the demands of this area. In addition, this reservoir is emptied in autumn to prevent floods from heavy rain events (Haro-Monteagudo et al., 2017). All the reservoirs are depicted in Fig. 1 , as well as how the JRB is divided into five sub-basins considering the reservoir positions and the hydrological features of the area.

Consequently, water stress is very high in this WRS, the ratio between water demands and water resources being around $90 \%$. This means scarcity and leads to overexploitation of water resources, mainly during drought events, such as those reported in the periods 1981-1986, 1992-1995, 20052008, and 2013-2018. During these periods, some environmental and water quality problems arose, as well as high economic losses, but the conjunctive use of surface and ground waters proved to be a useful and robust tool against them. Nowadays, some other alternatives are used to avoid drought effects, such as drought emergency wells and wastewater reuse for agriculture (Haro-Monteagudo et al., 2017).

The institution in charge of the water management in the JRBD is the Júcar River Basin Authority (JRBA), which is also the responsible for the elaboration of the Júcar River Basin District Management Plan (JRBDMP) (CHJ, 2015) and the Drought Management Plan (DMP) (CHJ, 2018).

In this area, climate projections were not incorporated explicitly in the analysis made with the aid of Decision Support Systems (CHJ, 2015) for the last version of the JRBDMP, where climate change effects were assessed by 
reducing the natural inflows in a certain percentage (CEDEX, 2010) for the future hydrological cycles of management (6 to 18 years). More recently, climate projections were considered in the CEDEX (2017) report about the assessment of the climate change impact on water resources and droughts in Spain, where change rates of meteorological and hydrological variables were extracted for the main Spanish basins. The general conclusion for this district was the future decrease in water resources and the increase in the number of droughts and their intensity, but the results of this benchmark study have not yet been used in decision-making.

\section{Material and methods}

This section presents the general methodology, which is based on the integration of climate projections into a model chain for future management and drought risk assessments through the characterization of natural inflows followed by deterministic and probabilistic approaches. The model chain consists of hydrological, management, stochastic and risk assessment models.

In Fig. 2, this methodology is represented in a simplified manner. It was divided into three main parts that are closely related to each other: i) the characterisation of natural inflows, where future inflows are extracted and some adjustments and corrections are applied to the ensemble to adapt it as much as possible to the current situation of the WRS; ii) the deterministic approach, where the future storage of the WRS is simulated and evaluated; and iii) the probabilistic approach, where the drought risk assessment is performed.

The main results that can be extracted from these sections are impacts on future inflows, future water storage in the WRS and a drought risk indicator. All of them are complementary and may be very useful in the decision-making process. 


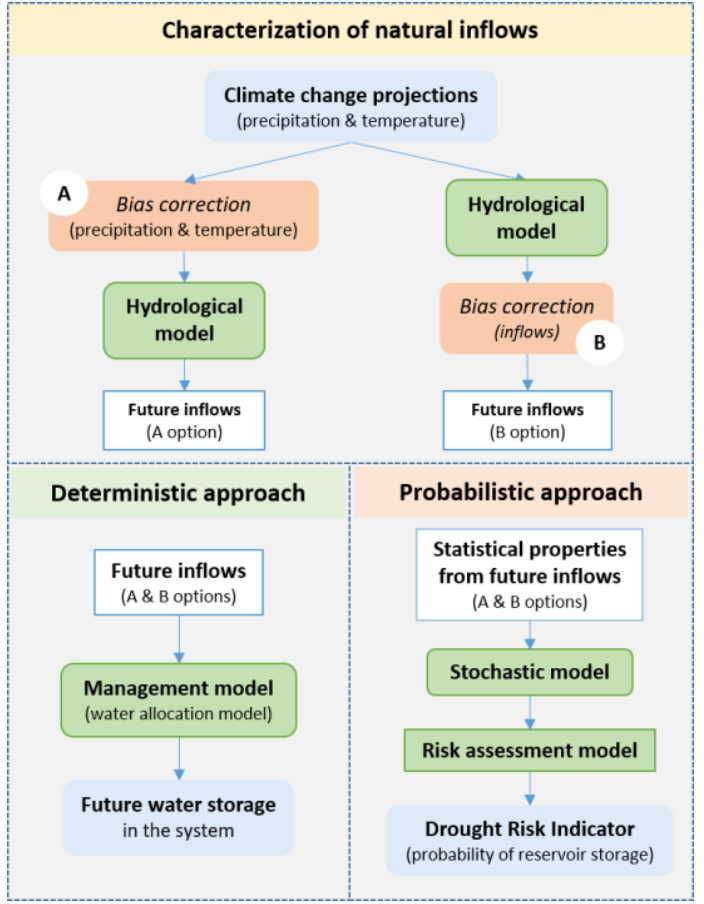

Figure 2. Methodology for the integration of climate change projections into the management and risk assessments to support decision-making.

The main improvement lies in the characterization of natural inflows, which is based on the extraction of inflows using the hydrological model and paying attention to some adjustment and/or correction processes. As can be observed in Fig. 2, the input data for this model are precipitation and temperature time series from climate change projections, consisting of a reference period and a future period. In this sense, if the reference period is not fitted to the observed values of the local data, it may need a bias correction. To this end, we proposed two alternatives for this characterisation, called option $A$ and option $B$. The main difference between these alternatives is the application of the bias correction before (option A) or after (option B) the use of the hydrological model.

In option $A$, the precipitation and temperature time series of the reference period are bias-corrected using the observed data. Then, this correction is extended to the future period series, which are introduced into the hydrological model to extract the future inflows. Conversely, raw precipitation and temperature time series from climate projections are introduced into the hydrological model in option B. Afterwards, the hydrological outputs of the reference period are bias-corrected using observed inflow data and this correction is extended to the future periods, thus obtaining the future inflows for this option. 
These are simply two different ways of working with the same data in order to know which alternative could be more reliable at the end of the process. Moreover, the good performance of the hydrological model in this step is essential, since it must strictly represent the features of the basin.

Besides that, once the reference and future inflows are extracted, they may be compared to extract the average change rates for the future, in other words, the effects of climate change on future inflows.

Afterwards, future inflows from options A and B (separately) are used in the deterministic approach, where they are introduced in the management model to simulate and evaluate the future water storage of the WRS.

On the other hand, the statistical properties of future inflows (both options separately) are used in the probabilistic approach, in which the stochastic model generates multiple equiprobable series (taking into account these statistical properties) to perform the risk assessment. In this process, all the generated series are introduced in the risk assessment model, where the management of the WRS is simulated for all of them, and then the management results are treated statistically to obtain a drought risk indicator related to the probability of reservoir storage in the WRS.

The steps of this methodology adapted to the JRB are detailed in the next sub-sections, where all the simulations were made taking into account the current conditions of the system, which may change in the future and affect water availability.

\subsection{Climate change projections and historical local data}

In this case, the climate projections from the SWICCA portal were selected for this study due to the good selection of Regional Climate Models (RCMs) for Europe it has available and the huge variety of data that can be downloaded at different temporal and spatial scales in a userfriendly format (.xlsx). This portal is a result of a Copernicus project that 
offers climate-impact data to speed up the workflow in the climate-change adaptation of water management across Europe.

Thus, precipitation and temperature time series of nine RCMs from the RCPs 4.5 and 8.5 (IPCC, 2014) were downloaded at daily and catchment scales (mean area $215 \mathrm{~km}^{2}$ ). These data came from the E-HYPE model (Hundecha et al., 2016), which uses global databases and Global Monitoring for the Environment and Security (GMES) satellite products as input data and then is forced by the European Centre for Medium-Range Weather Forecasts (ECMWF) and the Swedish Meteorological and Hydrological Institute (SMHI) to obtain meteorological, hydrological and another type of outputs for the entire continent (Hundecha et al., 2016; Suárez-Almiñana et al., 2017).

Table 1 shows the characteristics of the ensemble members used in this work. The reference period is 1971-2000 and the future periods are divided into 2011-2040 (near future), 2041-2070 (medium future), and 2071-2100 (far future). These data were obtained for the five sub-basins depicted in Fig. 1 and the last future period was reduced to 2 years due to the lack of data of two EMs.

Then, the observed values of meteorological variables from the Spain02 v4 dataset (Herrera et al., 2016) were used as the historical local data. Spain02 is a gridded dataset of daily time series and 0.110 of spatial resolution that covers the Iberian Peninsula and the Balearic Islands for the period 1971-2010.

Currently, this database is used in this area due to its good performance (Pedro-Monzonís et al., 2016; Suárez-Almiñana et al., 2017; Madrigal et al., 2018; García-Romero et al., 2019) and it was needed for the bias correction of the climate projections (option A) and to test the calibration of the hydrological model. Thus, four points of each sub-basin (Fig. 1) were taken and averaged to obtain a representative time series per sub-basin (Madrigal 
et al., 2018) for the same reference period provided by the climate projections.

Table 1. Ensemble member characteristics from SWICCA portal. Modified from: http://swicca.climate.copernicus.eu/wpcontent/uploads/2016/10/Metadata_Precipitation_catchment.pdf.

\begin{tabular}{|c|c|c|c|c|c|}
\hline RCP & GCM & RCM & Period & Institute & Name of ensemble members \\
\hline \multirow{5}{*}{4.5} & EC-EARTH & RCA4 & $\begin{array}{l}1970- \\
2100\end{array}$ & SMHI & SMHI_RCA4_EC-EARTH_rcp45 \\
\hline & EC-EARTH & RACMO22E & $\begin{array}{l}1951- \\
2100\end{array}$ & KNMI & $\begin{array}{c}\text { KNMI_RACMO22E_EC- } \\
\text { EARTH_rcp45 }\end{array}$ \\
\hline & $\begin{array}{l}\text { HadGEM2- } \\
\text { ES }\end{array}$ & RCA4 & $\begin{array}{l}1970- \\
2098\end{array}$ & SMHI & $\begin{array}{c}\text { SMHI_RCA4_HadGEM2- } \\
\text { ES_rcp45 }\end{array}$ \\
\hline & MPI-ESM-LR & REMO2009 & $\begin{array}{l}1951- \\
2100\end{array}$ & $\operatorname{CSC}$ & $\begin{array}{c}\text { CSC_REMO2009_MPI-ESM- } \\
\text { LR_rcp45 }\end{array}$ \\
\hline & CM5A & WRF33 & $\begin{array}{l}1971- \\
2100\end{array}$ & IPSL & IPSL-IPSL-CM5A-MR_rcp45 \\
\hline \multirow{4}{*}{8.5} & EC-EARTH & RCA4 & $\begin{array}{l}1970- \\
2100\end{array}$ & $\mathrm{SMHI}$ & SMHI_RCA4_EC-EARTH_rcp85 \\
\hline & EC-EARTH & RACMO22E & $\begin{array}{l}1951- \\
2100\end{array}$ & KNMI & $\begin{array}{c}\text { KNMI_RACMO22E_EC- } \\
\text { EARTH_rcp85 }\end{array}$ \\
\hline & $\begin{array}{l}\text { HadGEM2- } \\
\text { ES }\end{array}$ & RCA4 & $\begin{array}{l}1970- \\
2098\end{array}$ & SMHI & $\begin{array}{c}\text { SMHI_RCA4_HadGEM2- } \\
\text { ES_rcp85 }\end{array}$ \\
\hline & MPI-ESM-LR & REMO2009 & $\begin{array}{l}1951- \\
2100\end{array}$ & $\csc$ & $\begin{array}{c}\text { CSC_REMO2009_MPI-ESM- } \\
\text { LR_rcp85 }\end{array}$ \\
\hline
\end{tabular}

Another type of historical local data required in this analysis is inflow time series, which in this case are in natural regime (as if no anthropogenic modifications of the watercourse were applied) restored from observed data. These data were used in the calibration of the hydrological, management, and stochastic models, as well as for the bias correction in option B.

This dataset was provided by the JRBA for the period 1980-2012, which is used in the assessment of water resources reported in the JRBDMP, since the inclusion of previous years can lend to an overestimation of the available water resources in the system after the "80s effect" (Pérez-Martín 
et al., 2013; Hernández Bedolla et al., 2019). This effect consists of a significant decrease in the average precipitations and inflows from 1980 onwards.

Henceforth we will refer to these data as natural or observed inflows.

\subsubsection{Adjustment of the reference period}

Within the climate projections the reference period 1971-2000 was provided, but we proposed to reduce it to $1980-2000$ so as to consider the "80s effect". As reported previously, the data series considered most suitable for working in the management of water resources of this basin are those observed from 1980 onwards, in this case from 1980 to 2012 (CHJ, 2015). Thus, the inflow series from the period 1980-2012, the reference period proposed (1980-2000), and the one provided by climate projections (1971-2000) were compared to determine their differences in terms of total water resources, as well as to conclude if the proposed period is representing the current situation of the JRB. This process aims to avoid influencing the future with an excess of water resources through the application of the bias correction.

\subsubsection{Bias correction}

As the differences between climate projections and historical local data were notable in the reference period, a bias correction was advisable to adjust the pan-European data to the regional scale as much as possible. Hence, the correction of precipitation and temperature variables was considered in option A and the inflow correction was considered in option B.

In this sense, one of the most reputed methods in the literature is the quantile mapping, maybe because its application is relatively simple with good results, both for meteorological and hydrological variables (Grillakis et al., 2017; Manne et al., 2017; Teutschbein and Seibert, 2012). This method 
is based on the distribution function, which tries to keep the mean and standard deviation of the reference series (Collados-Lara et al., 2018). In this case, it is a feasible approach since the observations are of similar spatial resolution to the EMs data (Maraun, 2013).

This process was applied using the R statistical software (https://www.rproject.org/) at daily (precipitation and temperature time series) and monthly timescales (inflow time series) by interpolating the empirical quantiles for variables of the reference period based on the package developed by Gudmundsson et al. (2012). First, the correction was made in the reference period using observed data and then it was extended to the future periods.

In addition, two quantitative statistics can be extracted to know the goodness degree of the RCMs concerning the observed data. Thus, the Nash-Sutcliffe efficiency (NSE) (Nash and Sutcliffe, 1970) and percent bias (PBIAS) (Gupta et al., 1999) values from corrected and non-corrected ensembles were obtained (Zambrano-Bigiarini, 2020) to know if the bias correction improved the fitting to historical data based on the performance ratings on a daily timescale recommended by Kalin et al. (2010). The optimal values of NSE and PBIAS are 1 and 0 , respectively, and the proposed ratings are divided as follows: Very Good: NSE $\geq 0.7, \mid$ PBIAS| $\leq$ 25\%; Good: $0.5 \leq$ NSE < 0.7, 25\% < |PBIAS| $\leq 50 \%$; Satisfactory: $0.3 \leq$ NSE < $0.5,50 \%<|\mathrm{PBIAS}| \leq 70 \%$; Unsatisfactory: NSE $<0.3,|\mathrm{PBIAS}|>70 \%$.

\subsection{Modelling chain}

\subsubsection{AQUATOOL Decision Support System Shell (DSSS)}

To perform the modelling chain we employed the AQUATOOL DSSS (Andreu et al., 2009, 1996), which is a software widely used in the design of Spanish river basin plans, and also in many other basins abroad. It has several modules addressing different aspects of integrated water resources planning and management (WRPM) which are accessed from the same 
interface and are interconnected, an important feature to be considered in this study because the outputs of one model are the inputs of the others, as expected in a model chain.

The modules employed in this study were EVALHID (Paredes-Arquiola et al., 2012), SIMGES (Andreu et al., 2007), MASHWIN (Ochoa-Rivera, 2008, 2002) and SIMRISK (Sánchez-Quispe et al., 2001; Haro-Monteagudo, 2014; Haro-Monteagudo et al., 2017). These modules were used to build the hydrological, management, stochastic, and risk assessment models, respectively.

The EVALHID module has available several rainfall-runoff models with different structural complexities and parametrizations, but all of them have been aggregated with semi-distributed applications at the sub-basin scale (García-Romero et al., 2019; Hernández Bedolla et al., 2019; SuárezAlmiñana et al., 2017).

The SIMGES module is used to simulate the management of the WRS for water allocation. Here, a simplification of the WRS can be drawn using a friendly interface, where the databases related to all its elements (as reservoirs, contributions, demands, returns, aquifers, channels, environmental flows, etc.) can be filled along with the operating rules and the water use rights and priorities. All these features are considered to simulate the water allocation using an optimization algorithm for deficit minimization and maximum adaptation to the reservoir objective volume curves.

MASHWIN allows the building of multivariate stochastic models to generate multiple and equiprobable synthetic series, preserving the statistical properties of the original series for the generation. It is a complement for SIMRISK, since it needs a high number of flow series to perform the risk assessment. 
SIMRISK uses the multiple generated series to extract probabilistic results on reservoir storage and demand deficits among others. This tool can be used in the short, medium, and long term and its purpose is to inform the decision-makers about the probable state of WRS in the future. In this way, they can propose measures to minimize possible impacts and simulate different management scenarios to choose the most effective ones for reducing the impacts (Haro-Monteagudo, 2014).

\subsubsection{Hydrological model}

This model was employed to evaluate the amount of water resources produced in the basin using precipitation and PET time series from the ensemble as input data. The Hargreaves method (Hargreaves and Samani, 1985) was used to convert temperature into PET. In spite of the huge variety of methods with different skills to carry out this conversion (Milly and Dunne, 2017), its performance for this area is very valuable (Espadafor et al., 2011; Hernández Bedolla et al., 2019) and the data needed to apply it can be easily obtained.

In this case, the rainfall-runoff model HBV (Bergström, 1995) was selected to extract inflows from input data due to its good performance in this basin at daily scale after a proper calibration, which was performed by García-Romero et al. (2019) using two optimisation algorithms and the observed inflows from the period 1980-2007.

This model was run using bias-corrected time series of precipitation and PET in option A (Fig. 2), while in option B it was run using non-corrected data and then the output inflows were bias-corrected before inserting them in the rest of the models of the chain.

Thus, corrected and non-corrected precipitation and PET were introduced in the HBV model to assess its performance in the reference period and then generate future flows for the management and risk assessments. For both options, the simulation of future inflows was made 
using the time series from 2011 to 2098; in this way, initial conditions for all periods are conserved and maintained, as well as the tendency of future inflows.

In this case, the values of NSE and PBIAS statistics were also extracted to estimate the performance of the model run with Spain02 data to ensure its good calibration and then see if the bias correction improved the ensemble fitting to observed data. This time we based on the performance rating recommended by Moriasi et al. (2007) because we are comparing inflows at monthly time step. The ratings are divided as follows: Very Good: NSE $\geq$ 0.75, $\mid$ PBIAS| $\leq 10 \%$; Good: $0.65 \leq$ NSE < 0.75, 10\% < |PBIAS| $\leq 15 \%$; Satisfactory: $0.5 \leq$ NSE $<0.65,15 \%<|\mathrm{PBIAS}| \leq 25 \%$; Unsatisfactory: NSE < $0.5, \mid$ PBIAS $\mid>25 \%$.

Afterwards, the future ensembles from each sub-basin, period and option were compared with their respective ensemble baselines (19802000) to evaluate the climate change impact on future flows. The average change rates of future periods were obtained from the ensemble mean, not counting the increment or reduction of previous periods.

\subsubsection{Management model}

On this occasion, a simplified model of the Júcar River WRS was used to simulate the future water allocation for this basin. The main elements of the WRS were integrated into this model, as well as the operational rules and all the features involved in the current management of the system (CHJ, 2015).

The most interesting result we can extract from this model for the current study is the future water storage for the whole system, for which the volume was considered as the sum of the Alarcon, Contreras, and Tous reservoirs $\left(1796 \mathrm{hm}^{3}\right.$ ). Thus, the entire period of future inflow series (20112098) from the previous step was used to run this model and extract those results for options $A$ and $B$. In this way, the future evolution of storage 
values can be better observed to complement the results of the risk assessment.

\subsubsection{Stochastic model}

In this case a multivariate autoregressive model of first-order AR(1) was enough to generate the series after the time dependence parameter was calibrated using natural inflows from the 1980-2012 period. Then, this model was modified to adapt it for the generation of future series, since it was calibrated for the historical scenario. The statistical properties (mean and standard deviation) of future inflows obtained in the previous section (options $A$ and $B$ ) were used for this purpose. Hence, based on these future statistical properties, the model generated 1,000 synthetic series per EM and future period (the three considered) to feed the risk assessment model. The more series we generate, the more statistically robust the results at the end of the process (next step).

\subsubsection{Risk assessment model}

In this model, the water management of the system was simulated for all the series generated in the previous step, based on the Monte Carlo method. Then, the management outputs were treated statistically to extract the drought risk indicator. This probabilistic indicator informs about the evolution of the water storage of the system for the ensemble and the three future periods. As in the previous case, the sum of volumes of the main reservoirs was considered as the total storage of the system.

\section{Results}

In this section, the ensemble mean and the range covered by all EMs are shown in the figures. We decided to work with the ensemble of both RCPs 4.5 and 8.5, since in this way the approximation to the most likely future scenario (the RCP 6.0) accorded in the Paris Climate Change Conference 2015 (Barranco et al., 2018) is possible. The RCP 6.0 is an intermediate 
scenario of those employed, but no projections were available for this scenario, so this is a way of approaching it and to simplify the process.

\subsection{Analysis of variables and their bias correction}

Regarding the proposal of adjusting the reference period, Fig. 3 depicts how the average annual inflows observed from the period 1980-2012 and the reference period we proposed $(1980-2000)$ can be considered as equivalent (Suárez-Almiñana et al., 2020), while the reference period provided (1971-2000) has higher total inflows, which we want to avoid to have a good representation of the current situation of the JRB.

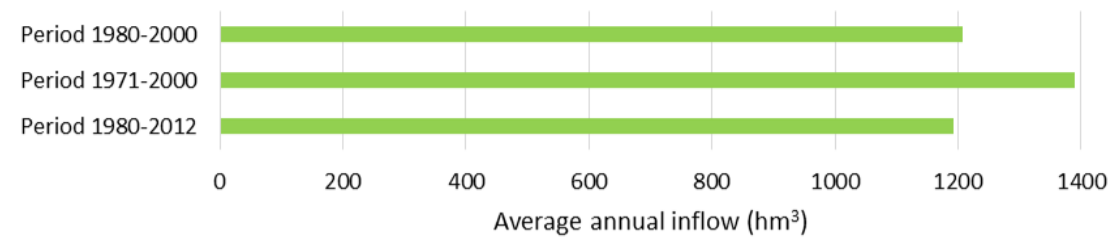

Figure 3. Average annual inflows observed in the Júcar River Basin for different historical periods. Modified from Suárez-Almiñana et al. (2020).

Thus, we proceed with the proposed reference period (1980-2000) to make the comparison between precipitation and temperature series of the ensemble and the observed data (Spain02). In this comparison, a general overestimation of temperature on the average year of this period and an underestimation of precipitation in most of the sub-basins was detected (Fig. 4). As these variables were not in the same line, the bias correction was applied to both variables.

While the overestimation of temperature disappeared after the application of this technique, the differences between the corrected ensemble of precipitations and the observed data were minimized (Fig. 4), as well as the average, but it is still overestimated in spring and summer. Moreover, Fig. 4 shows how the bias correction provided a little difference, favouring some months and affecting others in Molinar and Tous sub- 
basins, but very subtly in both cases. However, all these differences can be assumed to obtain more reliable flows in the next step (Fig. 5). In addition, based on the performance rating proposed by Kalin et al. (2010), the values of the PBIAS statistic made Alarcon and Sueca sub-basins go from good to very good performances after the bias correction, while the other subbasins did not change the very good status but the PBIAS values were more proximal to $0 \%$ (the optimal value). Despite this, the NSE values for all subbasins of non-corrected series were unsatisfactory and the bias correction was not enough to go beyond this threshold value (0.3).

Then, this correction was extended to the future series and the corrected temperature time series were converted into PET (using the Hargreaves method) to prepare the data for the hydrological model.

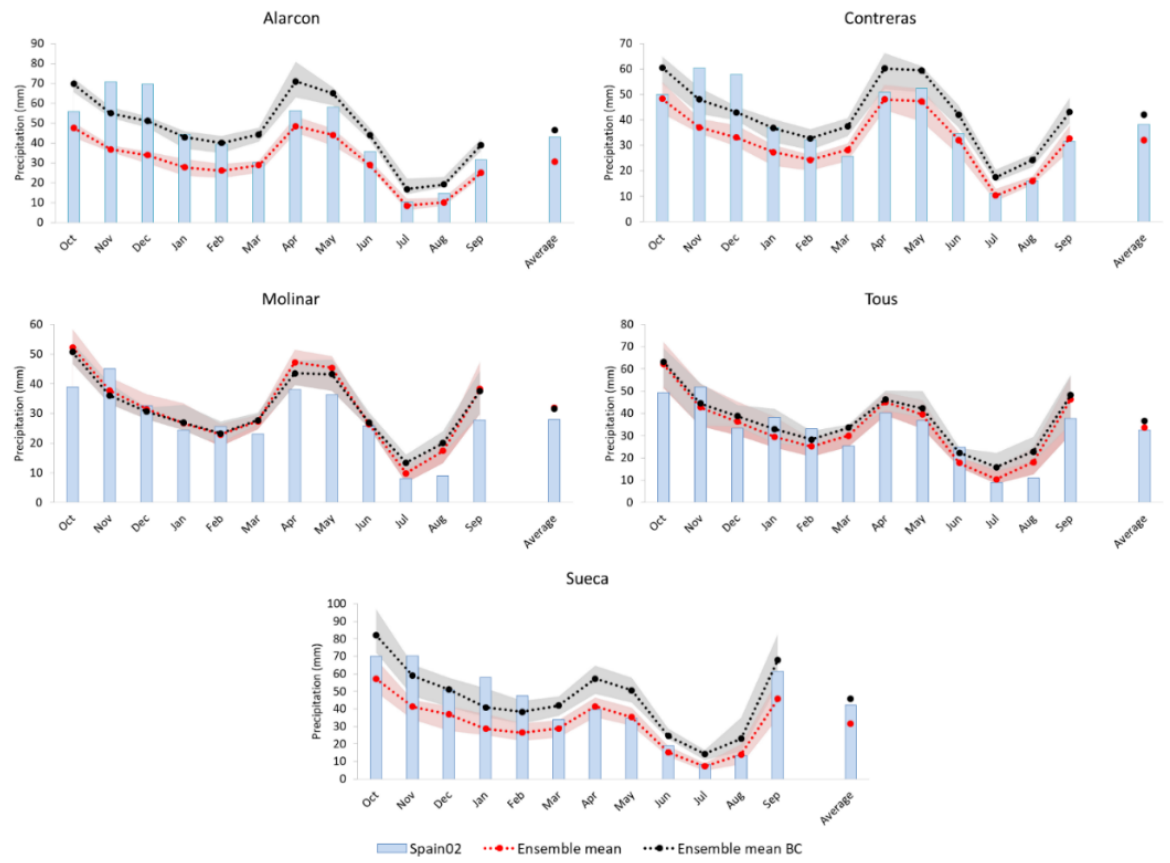

Figure 4. Average monthly and yearly bias-corrected precipitation (Ensemble mean BC) compared to the non-corrected precipitation (Ensemble mean) and the historical data (Spain02 data) in the reference period 1980-2000, where the shaded areas represent the entire ensemble. 


\subsection{Natural inflow characterisation}

In this section, corrected and non-corrected precipitation and PET time series were introduced into the HBV model to assess its performance and then generate future inflows for the management and risk assessments. In the next sub-sections the results for option $A$ and option $B$ are presented.

\subsubsection{Option A: HBV model simulation using bias-corrected data}

First, the inflows obtained from the HBV model fed with meteorological historical data (HBV-JRB Spain02) were compared with the observed inflows to assess its performance and validate it for the JRB. This comparison is illustrated in Fig. 5, where it can be seen how both data are generally close, as well as their averages, setting aside some differences that are likely due to its parametrization in the calibration process.

In order to assess the performance of the model, the NSE and PBIAS values were obtained for the case of the HBV-JRB Spain02 inflow series. Based on the performance ratings recommended by Moriasi et al. (2007), the NSE values showed very good and good performances for Alarcon and Contreras respectively (Table 2 ), while the values from the others subbasins had an unsatisfactory performance. However, the same ratings based on PBIAS values show how Contreras and Molinar have a very good performance; in Alarcon and Tous it performs well, and it is satisfactory for Sueca.

Thus, we can say that the HBV model is more accurate in the headwaters basins (Alarcon and Contreras) where the main reservoirs are placed, a fact to be considered from the water management point of view. In this way, the apparent mismatch in the Sueca sub-basin is not relevant for the purposes of this study since it is located in the final stretch of the river, where there is no reservoir regulation available. In the case of Molinar and Tous, inflows were underestimated, but these differences were expected because these sub-basins are the most heavily regulated and 
difficult to simulate with hydrological models, mainly due to their close connection with the underground component. Despite these differences, the performance of the HBV model using historical data can be considered as acceptable and quite good due to the huge complexity of this basin. Thus, it was decided to continue with the study simulating the ensemble inflows for the reference and future periods.

In this case, Fig. 5 (middle column) was completed including the inflows from the corrected ensemble (HBV-JRB Ensemble mean A). There, it can be seen how HBV-JRB Ensemble mean A inflows are more or less in line with the observed inflows and its average, setting aside some differences that are likely due to the HBV mismatches and the precipitation overestimation during the spring months coming from the bias-corrected process. The rates of Table 2 show a worse performance than those obtained with the historical data, indicating that the fitting of the corrected ensemble to the historical period is not good enough despite the bias correction and the good calibration of the HBV model.

In the Alarcon sub-basin, the ensemble is underestimating river flows in January and February (as in Contreras), while it is overestimating them in spring months, which is likely related to the outputs of the bias correction process in these months. In the Molinar sub-basin, this ensemble has higher values than the HBV-JRB Spain02 inflows and they are closer to the observed ones. In the case of Tous inflows, they are overestimated and in the Sueca sub-basin, both inflow series overestimate observed river flows from November to January and the ensemble also overestimates spring flows, which may be due to the overestimation in corrected precipitation.

\subsubsection{Option B: HBV model simulation using raw data and bias correction of flows}

In this section, the raw precipitation and PET time series of the reference period were introduced into the HBV model to extract the non-corrected 
inflows (HBV-JRB Ensemble mean) and evaluate if the previous correction was worth it or not.
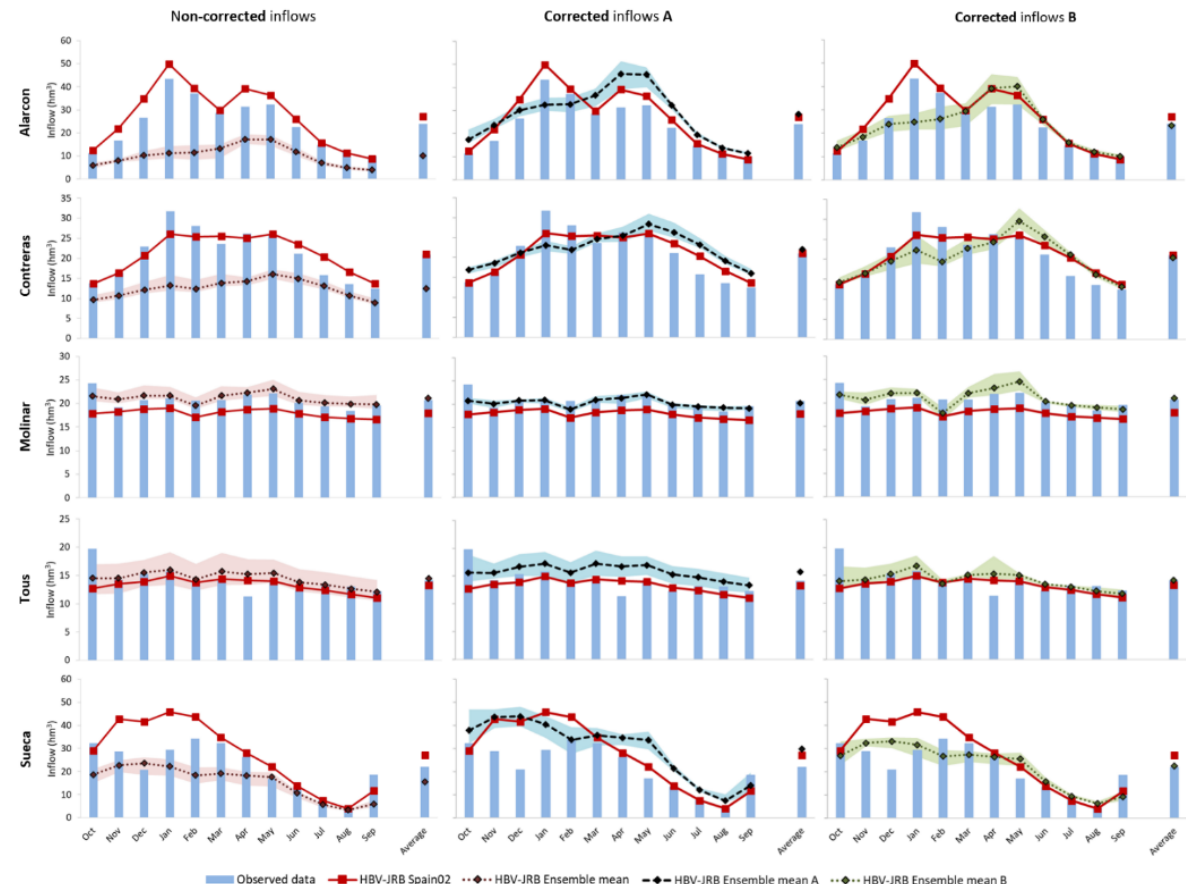

Figure 5. Average monthly and yearly inflows from the application of the HBV model using historical (HBV-JRB Spain02) and raw ensemble data (HBV-JRB Ensemble mean and shaded area) compared to the observed (Observed data) and corrected inflows (HBV-JRB Ensemble mean A, HBV-JRB Ensemble mean B and shaded areas) in the reference period 1980-2000.

Looking at Fig. 5 (left column) and Table 2, it is evident that a bias correction was needed on meteorological or hydrological data, since the non-corrected inflows are not representing the current situation of the basin, obtaining good performances only in Molinar and Tous sub-basins for PBIAS rates. These inflows of the reference period are highly underestimated in Alarcon and Contreras and if this is extended to future flows, the conclusions on the impacts of climate change can be misleading and have a severe and false view of the future. Thus, in this part was decided to correct those inflows and see the differences between correcting data before and after running the hydrological model. These 
inflows were also corrected using the quantile mapping method and the improvement was notable, particularly in the average fitting (Fig. 5, right column) and the ratings for the PBIAS values (Table 2). Despite this, there are some mismatches in accordance to the previous section (Fig. 5, middle and right columns), which are also captured by the NSE statistic. There are some underestimations in January and February in Alarcon and Contreras and spring months are also overestimated. However, in Tous and Molinar sub-basins the corrected inflows are more or less in line with the observed ones, and in Sueca the December and May inflows are overestimated.

Table 2. HBV-JRB model performance depending on simulated data and their PBIAS and NSE values based on the classification of the performance ratings recommended by Moriasi et al. (2007) for monthly time steps of streamflows. VG is a very good performance, G is good, $\mathrm{S}$ is satisfactory, and $U$ is unsatisfactory.

\begin{tabular}{|c|c|c|c|c|c|c|}
\hline & & Alarcon & Contreras & Molinar & Tous & Sueca \\
\hline \multirow{2}{*}{ HBV-JRB Spain02 } & PBIAS (\%) & G & VG & VG & G & $S$ \\
\hline & NSE & VG & G & $U$ & $U$ & $U$ \\
\hline \multirow{2}{*}{$\begin{array}{c}\text { HBV-JRB Ensemble } \\
\text { mean }\end{array}$} & PBIAS (\%) & $U$ & $U$ & VG & VG & $U$ \\
\hline & NSE & $U$ & $U$ & $U$ & $U$ & $U$ \\
\hline \multirow{2}{*}{$\begin{array}{c}\text { HBV-JRB Ensemble } \\
\text { mean A }\end{array}$} & PBIAS (\%) & $S$ & VG & VG & G & U \\
\hline & NSE & $U$ & $U$ & $U$ & $U$ & $U$ \\
\hline \multirow{2}{*}{$\begin{array}{c}\text { HBV-JRB Ensemble } \\
\text { mean B }\end{array}$} & PBIAS (\%) & VG & VG & VG & VG & VG \\
\hline & NSE & $U$ & $U$ & $U$ & $U$ & $\mathrm{U}$ \\
\hline
\end{tabular}

In general, these corrections can be considered as acceptable because non-corrected inflows are not an option to follow with the process, mainly due to the underestimation of headwater inflows. Moreover, at 
least the PBIAS ratings are better in the corrected options. Thus, these corrections were extended to future inflows.

\subsubsection{Impact on future inflows}

In Fig. 6, the impacts on future inflows are depicted per sub-basin, period, and option, as well as for the whole JRB.

As expected from other studies, the average year inflows decrease over future periods, but the average change rates differ based on the sub-basins and approach. If we compare both results (Fig. 6, top and middle), the reductions in the headwaters are important but more drastic in Alarcon for option $A$, where these change rates reach on average $-20 \%$ for the far future (Fig. 6, top right). However, the drastic decrease was found in the Molinar sub-basin of option B, which reaches $-21 \%$ on average in the far future (Fig. 6, middle right). Then, the inflow behaviour in Tous is remarkable (in both cases), since there is a large inflow increase in the near and medium futures (mostly in option B) that later decreases in the last period. The reason for this increase may be the high influence this subbasin has from the underground component. Moreover, increasing contributions to this sub-basin have been observed in recent years (Hernández Bedolla et al., 2019), which may continue and be translated into more contributions to this sub-basin until the second period.

However, the Sueca sub-basin has very similar decreases in both options, reaching $-18 \%$ on average in the last future period. The same happens if we look at the JRB as a whole (Fig. 6, bottom), the differences between using $A$ and $B$ approaches are minimal, reaching about $3 \%$ on average in the near future, $-3 \%$ in the middle future and $-12 \%$ in the far future.

Hence, we can say that there are important decreases in the headwaters, which may be a great challenge for future management because the main reservoirs are located in these areas. Moreover, the 
sharp reductions in Molinar and Sueca sub-basins are also concerning. In Molinar, reduced inputs may lead to a decrease in infiltration into the main aquifer in the basin (La Mancha Oriental), while in Sueca this may increase the demand and pressure on irrigation campaigns, since this is the area where the most of the irrigated crops are located (Fig. 1).

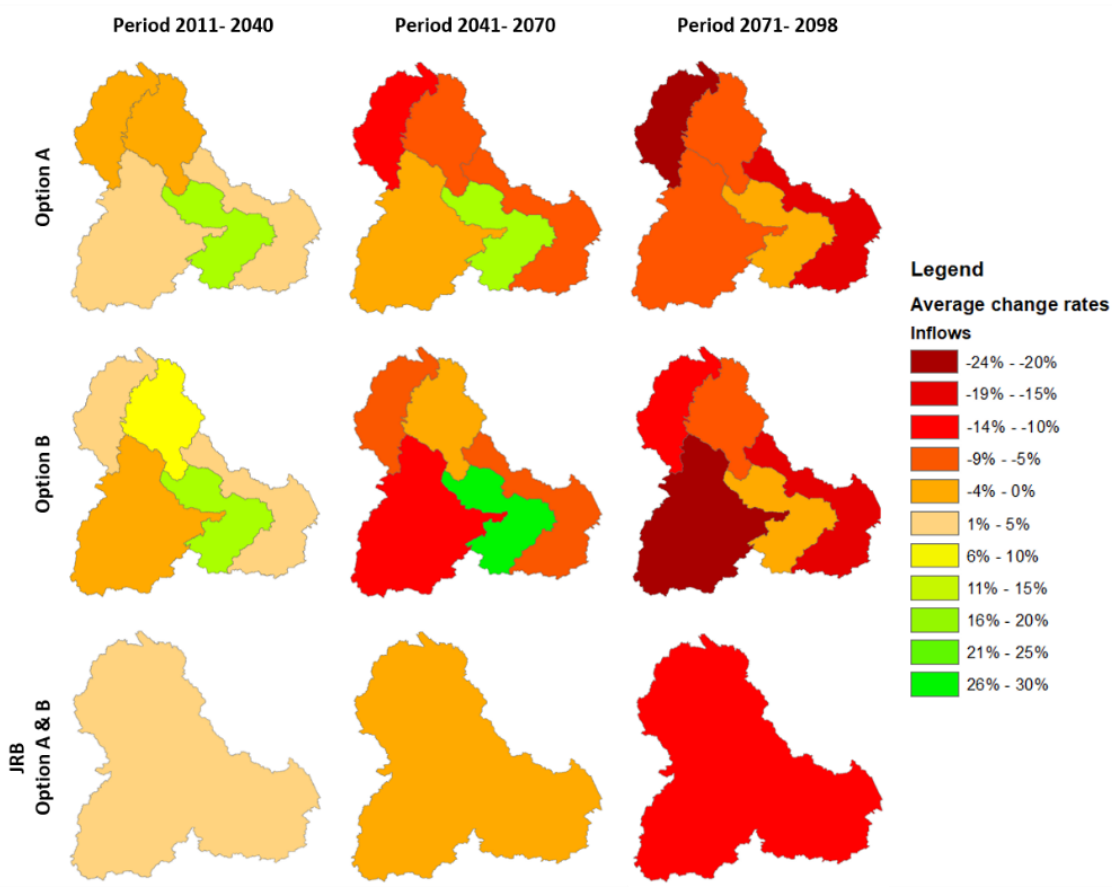

Figure 6. Average change rates of inflows per sub-basin and for the whole Júcar River Basin (bottom) for the future periods 2011-2040, 2041-2070, and 2071-2098, distinguishing between options A (top) and B (middle).

\subsection{Future water storage in the system}

In Fig. 7, the future storage volumes for the ensemble of both options, A and $B$, were represented, taking into account the total capacity of the system $\left(1796 \mathrm{hm}^{3}\right)$. These results were simulated with the water allocation model using future inflows from the previous section. 
In general, the mean values from option B (Fig. 7, bottom) are lower than those from option A (Fig. 7, up), which may result in worse climate change impacts from the middle of the century onwards. In addition, the frequency area of the EMs (lighter shaded area) shows the same conclusion, while in option A most EMs coincide in the upper parts of the storage volume with a couple of critical periods, and option B describes a more critical situation with several and recurrent drought periods from the second period onwards. However, the ensemble results (darker shaded areas) occupy practically the whole field of stored volume in the basin, indicating a huge uncertainty for the future.

The dispersion of option $A$ is less intense (see shaded area), mainly due to the minimum values of the EMs, which are higher than those of option $B$, especially until the mid-century. Therefore, the future conditions presented in option A provide more optimistic results, but their large dispersion makes results unreliable for the future, as in the case of option $B$.

Thus, these deterministic results have to be completed and complemented with probabilistic outcomes from the risk assessment in order to be more trustable from the point of view of decision-makers. 

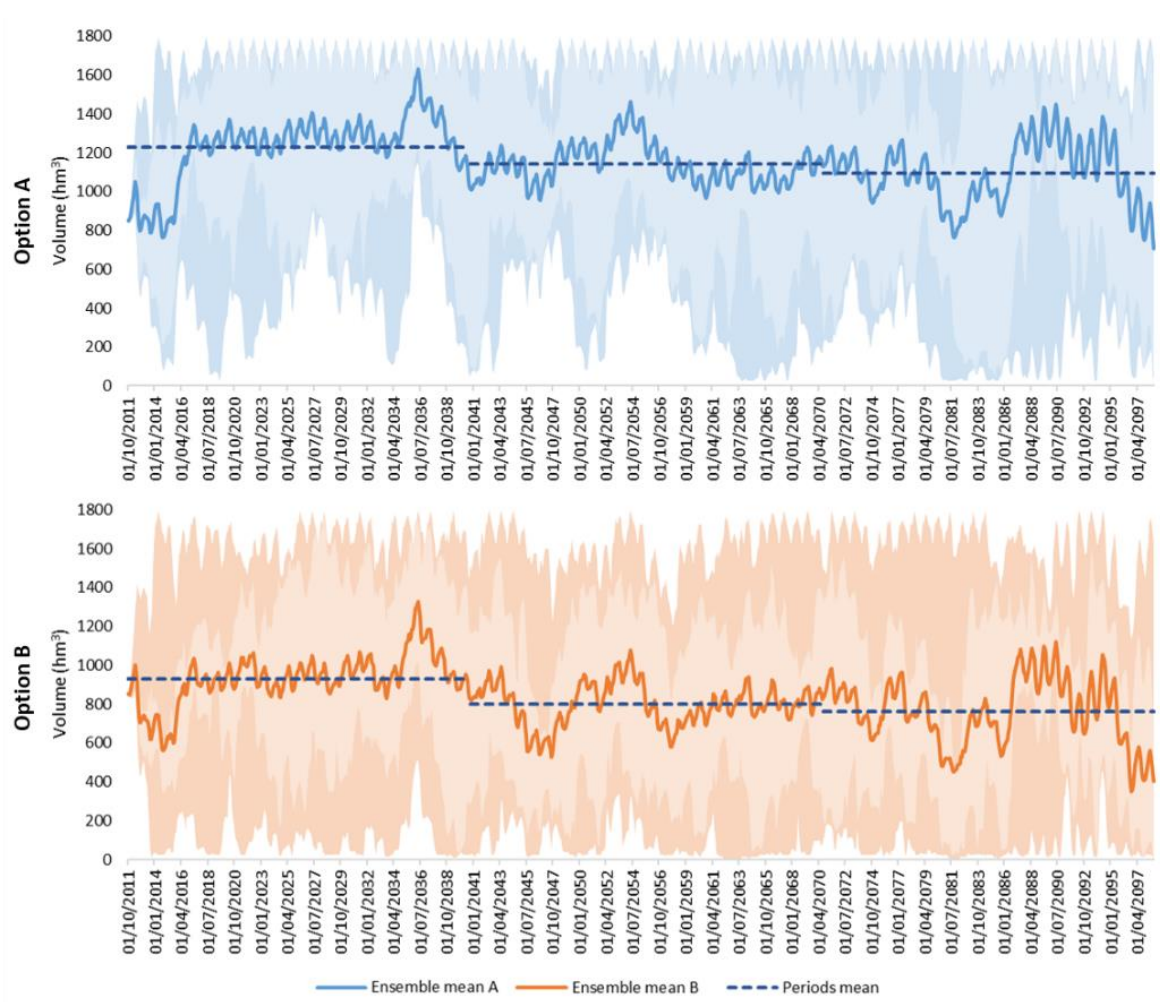

Figure 7. Evolution of the water storage in the Júcar WRS for the ensemble of options A (up) and B (bottom) in the future period 2011-2098.

\subsection{Drought risk indicator}

After the generation of multiple synthetic inflow series in the stochastic model and their integration in the risk assessment model, the probabilistic evolution of the reservoir storage in the system was extracted in the form of a risk indicator, which can be seen in Fig. 8 for both options A and B. There, the ensemble mean indicator for each future period and approach is represented, where the total capacity of the system $\left(1,796 \mathrm{hm}^{3}\right)$ was divided into 10 equal intervals and the probability of being in each interval was displayed for each period. 
The probabilities are very similar in all future periods of both alternatives. In both options, the probabilities of being under $50 \%$ of total capacity ( $898 \mathrm{hm}^{3}$, medium green colour) is about $80 \%$ in the near future, but these probabilities are around $70 \%$ and $60 \%$ in the medium and far future, respectively, and a little higher for option $\mathrm{B}$. This may lead to the conclusion that the probabilities of being at lower intervals are decreasing over the periods despite the average inflow reductions obtained in Fig. 6 and the mean future volumes observed in Fig. 7, but this is due to the greater probability of falling in any interval $(\approx 10 \%)$ as time goes on. This indicates a high uncertainty for the future, since there is a large variation in future simulated storage volumes, as was expected from the shaded areas depicted in Fig. 7.
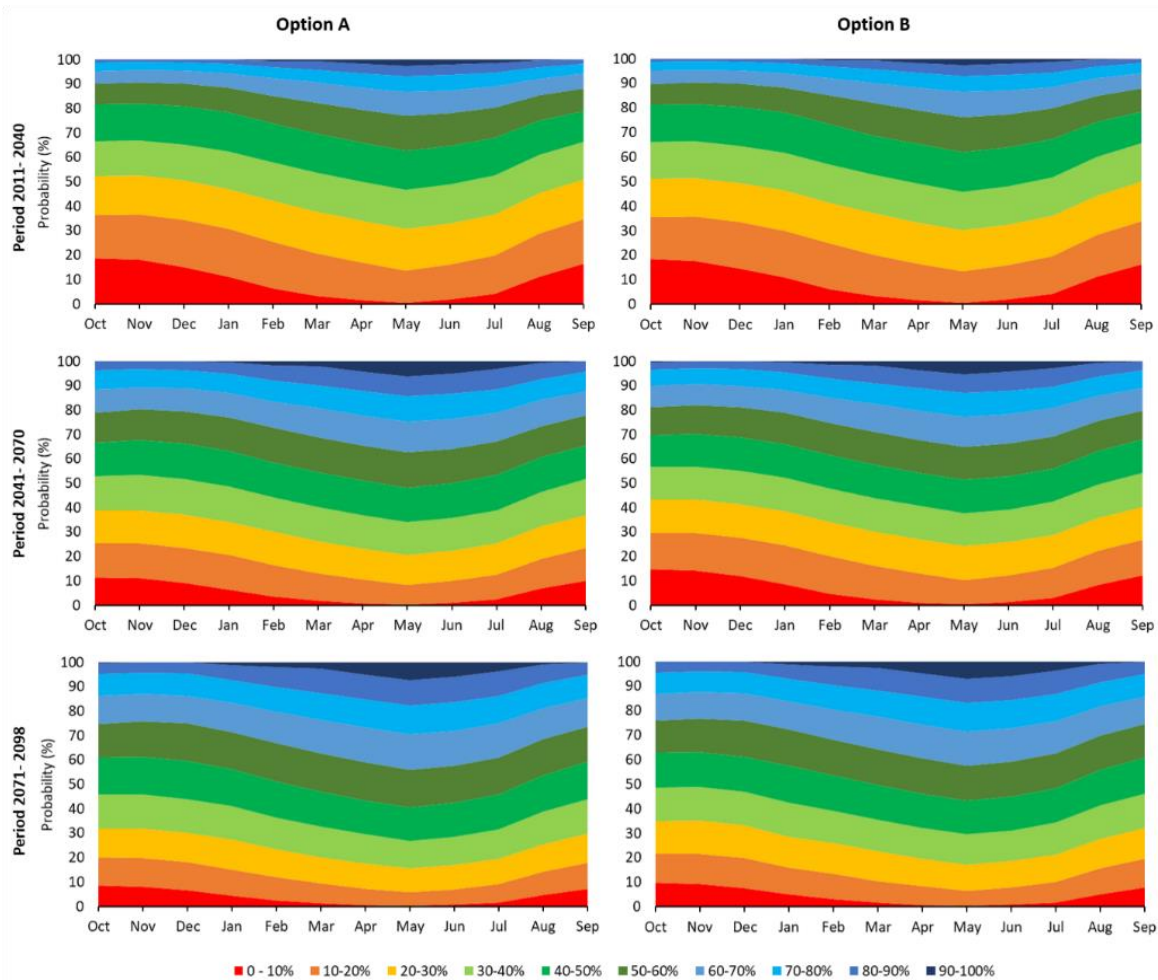

Figure 7. Drought risk indicator of the ensemble mean per option ( $A$ and $B$ ) and future period (2011-2040, 2041-2070, and 2071-2098). 
Looking at the indicator results, we decided to pay attention to the exceedance probabilities of March and September (Fig. 9) as these months coincide with the start and the end of the irrigation season, respectively. In addition, those results for September also inform about the final state of the system for each future period, coinciding with the end of the hydrological year.

In the first period, the range of exceedance probabilities covered by the ensemble is very tight in both months, coinciding more or less with the ensemble mean of both approaches, while in the other periods this range is wider due to a higher dispersion of the EMs. In general, ensemble results from option A show higher probabilities of exceeding higher storage volumes in both months, as was expected from results shown by Fig. 7 and Fig. 8.
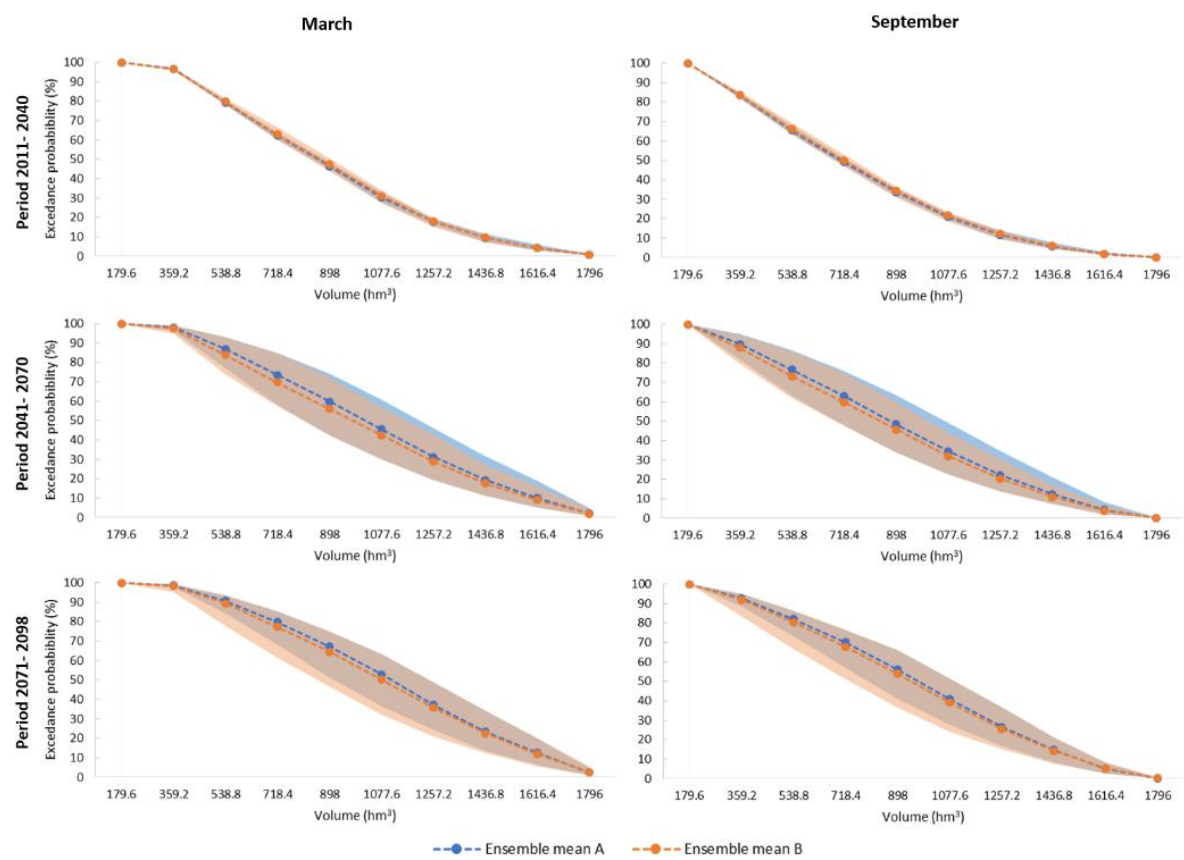

Figure 8. Exceedance probability of the ensembles (shaded areas) coming from options A and $B$ in the start (March) and the end (September) of the irrigation season for the future periods 2011-2040, 2041-2070, and 2071-2098. 
In addition, March results show higher percentages of exceedance probability for the same volume if they are compared with those from September. These results are logical due to the winter storage that provides more water resources for the start of the irrigation season, while in September these values are lower due to water allocation during this season and the summer period, which normally lacks precipitation incomes.

For example, in the near future of March, the probabilities of exceeding $50 \%$ of total capacity are on average $46 \%$ in both approaches, while in September this value is $34 \%$. Then, these probabilities in the second period of March are $60 \%$ (ensemble mean A) and $56 \%$ (ensemble mean B), but ranges are between $42 \%-74 \%$ and $42 \%-72 \%$, respectively. In the same period for September these values are $48 \%$ (ensemble mean A) and $46 \%$ (ensemble mean B), but ranges are between $34 \%-63 \%$ and $34 \%-60 \%$, respectively. In the far future the same happens, higher mean values of exceedance probabilities for the same volume and wide ranges covered by the ensemble.

Hence, the dispersion and uncertainty beyond the first period is considerable, as was noted in Fig. 8, and the probabilities of exceeding 50\% of total capacity are around $10 \%$ higher in March than in September for all periods, indicating more probabilities of water availability in March that may not compromise the irrigation season.

\section{Discussion}

This work has highlighted the most relevant points to be considered for integrating climate projections into decision-making processes. The proposed methodology is easy to understand and to replicate but it has to be adapted to the features of the case study, so a high level of knowledge of the WRS is an important requirement to implement it. In this case, it was adapted to a Mediterranean basin with water scarcity problems and long periods of drought. Consequently, the more attention we pay to each step, the better the results. In spite of this, the indicator did not provide 
conclusive results due to the great dispersion of climatic projections, especially in the last two future periods. Therefore, it seems necessary to discuss the process step by step to estimate possible mistakes and improvements.

First, the data from SWICCA were selected due to the pre-processing they went through, i.e., of filtering the models that best fit in the European area. Despite this, it is stated in the literature that for the Mediterranean area it is very difficult to find reliable data or data with enough skill to work with them with confidence (Barranco et al., 2018; Collados-Lara et al., 2018), especially if these are hydrological data (Suárez-Almiñana et al., 2017). This is why we decided to work with meteorological variables, even though the process may be simpler and shorter using hydrological variables. In Suárez-Almiñana et al. (2017) it was stated that pan-European models do not yet have the capacity of representing the hydrologic characteristics of complex basins. This may be due to the large scale of the European hydrological models, where the tight relationship between rivers and aquifers coupled with the high anthropization of rivers (typical of dry areas) is not well represented unless the hydrological model was well tailored to the basin. In addition, it is also important to consider that final results will depend on the input data selected, so this first step may be the key for the rest of the process. In this way, the proposed methodology would be used in other basins incorporating meteorological variables to avoid this problem.

On the other hand, we believe that the reduction of the reference period is a good choice to start with data more in line with the current situation of the basin. This fact has also been demonstrated in SuárezAlmiñana et al. (2020), where the uncertainty about the effects of climate change on the future inflows of this basin was minimized.

Then, looking at Fig. 4 and Fig. 5, where raw and corrected precipitation and inflows are shown, there is no doubt that the application of some kind of bias correction was necessary. Working with the raw data would lead to 
unfavourable results for the future, since the underestimation of flows in the headwaters (where the major reservoirs are located) are notable, this fact may also lead to alarming conclusions about the future hydrology in this basin, which may not be correct. Therefore, the quantile mapping technique was applied for both options A and B. This technique is highly recommended in the literature (Grillakis et al., 2017; Collados-Lara et al., 2018; Manne et al., 2017; Teutschbein and Seibert, 2012), but after having tried other simpler techniques such as month-specific correction factors (Suárez-Almiñana et al., 2017), the differences between their performances are not significant, although the fitting was improved especially in the annual average. It seems that the currently available methods of bias correction may not provide fully satisfactory results, neither a satisfactory physical justification, since they may hide uncertainty rather than reduce it (Ehret et al., 2012).

The combination of NSE and PBIAS statistics also showed how the bias correction did not improve much more the goodness of fit of the ensemble, despite the good calibration of the hydrological model. In fact, they have to be used with caution because PBIAS may be influenced by the uncertainty (Moriasi et al., 2007) and the rating values recommended for the NSE may be too restrictive, since only negative values of NSE indicate an unacceptable performance (Moriasi et al., 2007) and this did not happen in the case of Molinar, Tous, and Sueca when the HBV was tested with historical data, even though they were very low $(\approx 0.2)$. The hydrological model is another source of uncertainty and it has to be considered (Muerth et al., 2013), but it is significantly less important than that provided by the RCMs (Vetter et al., 2014).

All these suggest that the skill of climate change projections needs to be improved in order to work with them effectively. Based on Ehret et al., (2012) this would be achieved by increasing the RCM resolutions at the convection-permitting scale in combination with ensemble predictions based on sophisticated approaches for ensemble perturbation. 
Meanwhile, a future consideration might be the application of improved bias correction methods (Switanek et al., 2017) or a seasonal correction, which may be more relevant for water management and especially in this area, which is totally conditioned by the irrigation season. However, some authors said that in some cases, the RCMs are not able to reproduce drought statistics from the observed series (Collados-Lara et al., 2018; Cook et al., 2008; Seager et al., 2008), so a correction focussed on drought statistics is also a feasible solution to try to leave out the mismatches between reference periods.

Regarding the impacts on future inflows, they experimented with decreases in both options, which is consistent with several studies conducted in this area (Barranco et al., 2018; CEDEX, 2017; Marcos-Garcia et al., 2017). But the behaviour of Tous sub-basin is remarkable because the rate increases until the second period. As mentioned above, this may be conditioned by its connection with the aquifer and the increase in contributions observed in recent years (Hernández Bedolla et al., 2019). This increase in contributions seems to be captured by the models, since the rainfall rate also increases in the first period, maintaining the average of the baseline until the second period and sinking in the last period. This increase in rainfall combined with the increasing contributions from the groundwater (included in the hydrological model) and the low water resources of the baseline may lead to those increments in percentage. In any case, the variability of changes between sub-basins is not an isolated case (Folton et al., 2019).

However, if we focus on the average change rates of the whole JRB (Fig. 6 , bottom), their values may seem rather low when they are compared to the benchmark study of the CEDEX (2017). This study estimates average reductions (RCPs 4.5 and 8.5 ) of $-7 \%$ (near future), $-18 \%$ (medium future) and $-28 \%$ (far future) for the entire JRBD, although it is indicated that change rates can be applied to all its points (Barranco et al., 2018). The main reasons for these differences may lie in the reference period of the 
report (1960-2000) and the lack of bias correction, even though precipitation on the Mediterranean side was underestimated (Barranco et al., 2018). In that reference period, the data before the 80 s provide a much more favourable scenario in terms of the availability of water resources compared to the current one. Therefore, when future change rates are obtained, the decreases for the future are more drastic. These simple premises may explain why the change rates of this work are lower or more "optimistic" than those provided by the CEDEX (2017) report.

Then, it was decided to continue with the statistical characteristics of future flows to obtain the drought risk indicators, where the decreasing behaviour observed in the inflows was not equally evident (Fig. 8). Only in the first period can a complicated scenario in which the probability of being below $50 \%$ of the total storage capacity of the system is $80 \%$ be seen. However, in the rest of the periods the probabilities of being in any of the intervals is practically the same $(\approx 10 \%)$. The reason for this is most clearly seen in the probabilities of exceedance capacity (Fig. 9), where the range of probabilities covered by the ensemble is very wide, indicating that their dispersion from the second period onwards is very high and no conclusions can be drawn from them.

The results from the simulation of the future water management supports the dispersion theories extracted from the evaluation of the indicators and the exceedance probabilities, since in Fig. 7 the ensemble is occupying practically the entire storage volume of the WRS in both options (larger in option B), indicating that anything could happen and confirming that the uncertainty of climate projections is considerable. In addition, looking at Fig. 7, it seems that the bias correction of flows provides more dispersion and also lower average values of water storage, which from the point of view of water management is more interesting since the worst scenarios were considered, but the uncertainty is so high that any option can be chosen. In this way, we can understand why it is better to work in terms of probabilities when the future is so uncertain. 
Furthermore, the fact of choosing the dammed volumes and their evolution as a reference is motivated by the great influence that these volumes have on the JRB drought indicator (CHJ, 2018), representing almost $50 \%$ of the indicator's value (Haro-Monteagudo et al., 2017). Therefore, the proposed indicator can serve as an approximation of the current drought indicator and complement it.

Although the results are not conclusive, the proposed methodology is feasible when integrating future projections in the decision-making processes, but for this area the skill of climate projections needs to be improved. This uncertainty and the absence of a clear and real danger leads the decision-makers to justify inaction (Lemos and Rood, 2010), but the decreasing tendencies of future flows and the indicator for the near future are signals to be considered, since taking preventive measures may be the key to avoid severe socioeconomic and environmental impacts. In addition, this type of study seeks to complement or improve the RBMP, but at the same time, its conclusions affect the delicate balance of the system, highlighting the need to review the current operating rules for the future, as well as the water allocations and other related elements of the system.

\section{Conclusion}

In this paper, a robust and adaptive methodology was presented to support the decision-making process in complex basins, taking into account the influence of climate change in WRPM. The new perspective of this method regarding current approaches lies in the integration of climate change projections into a model chain to perform future management and drought risk assessments, with an emphasis on improving the process with the characterisation of natural inflows. This approach introduces an important advantage in trying to fit climate data to the WRS through some adjustment and bias correction processes, which are essential to adapt climate data and models as much as possible to the basin features. 
All of the process was designed with the objective in mind of transforming the information provided by climate services into useful information for decision-making, in order to be understood and trusted by stakeholders and decision-makers. Hence, the key outcomes that can be extracted at different points of the model chain (future change rates, water storage, and drought risk indicator) are presented in intuitive formats to be easily understood. In this way, it is expected that the existing gap between climate services and WRPM decision-making will be reduced, contributing to a better adaptation to climate change.

The application of this methodology to the JRB has shown how it can be tailored to systems affected by high hydrologic variability and recurrent droughts, taking into account that a good knowledge of the WRS features is essential to get good results. In this case, after the adjustment of the reference period to incorporate an abrupt decrease in average precipitation ("80s effect") and the application of both types of bias correction (to meteorological and hydrological variables), a concerning decrease in future inflows was observed. These decreasing rates were also reflected in the drought risk indicator for the near future, where the very high probability of having values of the total water stored in the WRS less than half of the total storage capacity calls for action.

Unfortunately, the results from the middle century onwards are not conclusive due to the high dispersion of the EMs, indicating that there is a much higher uncertainty in predicting the future more than 30 years in advance. This leads to the conclusion that the skill of climate projections needs to be improved to overcome the difficulties to extract robust and reliable results from them. In this way, another branch of the abovementioned gap could be reduced. Despite this, the improved methodology constitutes a step forward in the inclusion of climate projections in the WRPM decision-making process. And for the JRB case of study, results obtained show that it is time for action to mitigate the impacts in the near future. 
Data availability. The full Spain02 v4 dataset is freely distributed (in NetCDF format) for research purposes (http://www.meteo.unican.es/files/images/copyright_en.pdf) from the EscenariosPNACC dataset from the UC climate data service. It is available at http://www.meteo.unican.es/datasets/spain02.

The climate projection from SWICCA portal can be freely downloaded at http://swicca.climate.copernicus.eu/indicator-interface/graphs-and-download/ under Creative Commons Attribution-ShareAlike 4.0 International (CC BY-SA 4.0) license conditions.

The natural flows from the Júcar River Basin were provided by the JRBA for research purposes.

Author contribution. SSA, AS and JM collected the data. SSA, AS, JPA and JA designed the methodology. SSA performed the calculations and analysed the results with AS and JA. SSA prepared the paper with contributions from all coauthors: JPA, JM, JA, and AS.

Competing interests. The authors declare that they have no conflict of interest.

Special issue statement. This article is part of the special issue "Hydrological cycle in the Mediterranean (ACP/AMT/GMD/HESS/NHESS/OS inter-journal SI)". It is not associated with a conference.

Acknowledgments. The authors thank the Spanish Research Agency (MICINN) for the financial support to the RESPHIRA project (PID2019-106322RB-100) and the MINECO for the financial support to the ERAS project (CTM2016-77804-P, including EU-FEDER funds). Additionally, we also value the support provided by the European Community's in financing the projects SWICCA (ECMRWF-Copernicus-FA 2015/C3S_441-LOT1/SMHI) and IMPREX (H2020-WATER-2014-2015, 641811).

It is also important to mention the Research and Development Support Programme (PAID-01-17) from the Universitat Politècnica de València for encouraging and facilitating training contracts for research staff.

Finally, the authors thank AEMET and UC for the data provided for this work (Spain02 v4 dataset, available at http://www.meteo.unican.es/datasets/spain02).

Financial support. This research has been supported by the Improving PRedictions and management of hydrological EXtremes (IMPREX) (grant no. 641811). 
Review statement. This paper was edited by Giuseppe Tito Aronica and reviewed by three anonymous referees.

\section{References}

Andreu, J., Capilla, J., Sanchís, E., 1996. AQUATOOL, a generalized decision-support system for water-resources planning and operational management. J. Hydrol. 177, 269-291. doi:10.1016/0022-1694(95)02963-X

Andreu, J., Ferrer-Polo, J., Pérez, M.A., Solera, A., 2009. Decision support system for drought planning and management in the Jucar river basin, Spain, in: 18th World IMACS/ .... pp. 3223-3229.

Barranco, L., Dimas, M., Jiménez, A., Estrada, F., 2018. Nueva evaluación del impacto futuro del cambio climático en los recursos hídricos en España. Ingeiría Civ. 191/2008, 34-55.

Bergström, S., 1995. The HBV Model, in: Computer Models of Watershed HyDrology, Water Resources Publications, Highlands Ranch. Colorado, pp. 443476.

CEDEX, 2017. Evaluación del impacto del cambio climático en los recursos hídricos y sequías de España. Informe Técnico Centro de Estudios Hidrográficos - CEDEX, Tomo único, clave CEDEX 42-415-0-001, Centro de Publicaciones, Secretaría General Técnica del Ministerio de Fomento, Madrid, España.

CEDEX, 2010. Estudio de los impactos del cambio climático en los recursos hídricos y las masas de agua. Ficha 1: Evaluación del impacto del cambio climático en los recursos hídricos en régimen natural. Informe Técnico Centro de Estudios Hidrográficos - CEDEX, Tomo único, clave CEDEX 42-407-1-001, Centro de Publicaciones, Secretaría General Técnica del Ministerio de Fomento, Madrid, España.

Chatterjee, S., Daniels, M.D., Sheshukov, A.Y., Gao, J., 2018. Projected climate change impacts on hydrologic flow regimes in the Great Plains of Kansas. River Res. Appl. 34, 195-206. doi:10.1002/rra.3249

CHJ, 2018. Plan Especial de Sequía Demarcación Hidrográfica del Júcar, Ministerio de Agricultura y Pesca, Alimentación y Medio Ambiente, Valencia, España.

$\mathrm{CHJ}$, 2015. Plan Hidrológico de la Demarcación Hidrográfica del Júcar, Memoria cliclo de planificación hidrológica 2015-2021, Ministerio de Agricultura, Alimentación y Medio Ambiente, Valencia, España. 
Collados-Lara, A.J., Pulido-Velazquez, D., Pardo-Igúzquiza, E., 2018. An integrated statistical method to generate potential future climate scenarios to analyse droughts. Water (Switzerland) 10. doi:10.3390/w10091224

Cook, B.I., Miller, R.L., Seager, R., 2008. Dust and sea surface temperature forcing of the 1930s "Dust Bowl" drought. Geophys. Res. Lett. 35, 1-5. doi:10.1029/2008GL033486

Ehret, U., Zehe, E., Wulfmeyer, V., Warrach-Sagi, K., Liebert, J., 2012. HESS Opinions "should we apply bias correction to global and regional climate model data?" Hydrol. Earth Syst. Sci. 16, 3391-3404. doi:10.5194/hess-16-3391-2012

Espadafor, M., Lorite, I.J., Gavilán, P., Berengena, J., 2011. An analysis of the tendency of reference evapotranspiration estimates and other climate variables during the last 45 years in Southern Spain. Agric. Water Manag. 98, 1045-1061. doi:10.1016/j.agwat.2011.01.015

Folton, N., Martin, E., Arnaud, P., L'Hermite, P., Tolsa, M., 2019. A 50-year analysis of hydrological trends and processes in a Mediterranean catchment. Hydrol. Earth Syst. Sci. 23, 2699-2714. doi:10.5194/hess-23-2699-2019

García-Romero, L., Paredes-Arquiola, J., Solera, A., Belda, E., Andreu, J., SánchezQuispe, S.T., 2019. Optimization of the multi-start strategy of a direct-search algorithm for the calibration of different rainfall-runoff models for the water resources assessment. Water 1-27. doi:10.3390/w11091876

Grillakis, M.G., Koutroulis, A.G., Daliakopoulos, I.N., Tsanis, I.K., 2017. A method to preserve trends in quantile mapping bias correction of climate modeled temperature. Earth Syst. Dyn. 8, 889-900. doi:10.5194/esd-8-889-2017

Gudmundsson, L., Bremnes, J.B., Haugen, J.E., Engen-Skaugen, T., 2012. Technical Note: Downscaling RCM precipitation to the station scale using statistical transformations - a comparison of methods. Hydrol. Earth Syst. Sci. 16, 33833390. doi:10.5194/hess-16-3383-2012

Gupta, H. V., Sorooshian, S., Yapo, P.O., 1999. Status of automatic calibration for hydrologic models: Comparison with multilevel expert calibration. J. Hydrol. Eng. 4, 135-143.

Hargreaves, G.H., Samani, Z.A., 1985. Reference crop evapotranspiration from temperature. Appl. Eng. Agric. 1 (2), 96-99.

Haro-Monteagudo, D., 2014. Methodology for the optimal management design of water resources system under hydrologic uncertainty 373. 
Haro-Monteagudo, D., Solera, A., Andreu, J., 2017. Drought early warning based on optimal risk forecasts in regulated river systems: Application to the Jucar River Basin (Spain). J. Hydrol. 544, 36-45. doi:10.1016/j.jhydrol.2016.11.022

Hernández Bedolla, J., Solera, A., Paredes Arquiola, J., Roblero Escobar, C.X., 2019. Análisis del cambio en las aportaciones hidrológicas en la cuenca del río Júcar a partir de 1980 y sus causas. Ing. del agua 23, 141-155. doi:10.4995/ia.2019.10582

Herrera, S., Fernández, J., Gutiérrez, J.M., 2016. Update of the Spain02 gridded observational dataset for EURO-CORDEX evaluation: Assessing the effect of the interpolation methodology. Int. J. Climatol. 36, 900-908. doi:10.1002/joc.4391

Hewitt, C., Buontempo, C., and Newton, P.: Using Climate Predictions to Better Serve Society's Needs, Eos Trans. AGU, 94, 105-107, doi: 10.1002/2013EO110002, 2013.

Hundecha, Y., Arheimer, B., Donnelly, C., Pechlivanidis, I., 2016. A regional parameter estimation scheme for a pan-European multi-basin model. J. Hydrol. Reg. Stud. 6, 90-111. doi:10.1016/j.ejrh.2016.04.002

IPCC, 2014. Summary for Policymakers, Climate Change 2014: Synthesis Report. Contribution of Working Groups I, II and III to the Fifth Assessment Report of the Intergovernmental Panel on Climate Change. Geneva, Switzerland. doi:10.1017/СBO9781107415324

Kalin, L., Isik, S., Schoonover, J.E., Lockaby, B.G., 2010. Predicting Water Quality in Unmonitored Watersheds Using Artificial Neural Networks. J. Environ. Qual. 39, 1429-1440. doi:10.2134/jeq2009.0441

Lemos, M.C., Rood, R.B., 2010. Climate projections and their impact on policy and practice. Wiley Interdiscip. Rev. Clim. Chang. 1, 670-682. doi:10.1002/wcc.71

Madrigal, J., Solera, A., Suárez-Almiñana, S., Paredes-Arquiola, J., Andreu, J., Sánchez-Quispe, S.T., 2018. Skill assessment of a seasonal forecast model to predict drought events for water resource systems. J. Hydrol. 564, 574-587. doi:10.1016/j.jhydrol.2018.07.046

Manne, D., Tachikawa, Y., Ichikawa, Y., Yorozu, K., 2017. Evaluation of Bias Correction Methods for Future River Discharge Projection. J. Japan Soc. Civ. Eng. Ser. G (Environmental Res. 72, I_7-I_12. doi:10.2208/jscejer.72.i_7

Maraun, D., 2013. Bias correction, quantile mapping, and downscaling: Revisiting 
the inflation issue. J. Clim. 2137-2143. doi:10.1175/JCLI-D-12-00821.1

Marcos-Garcia, P., Lopez-Nicolas, A., Pulido-Velazquez, M., 2017. Combined use of relative drought indices to analyze climate change impact on meteorological and hydrological droughts in a Mediterranean basin. J. Hydrol. 554, 292-305. doi:10.1016/j.jhydrol.2017.09.028

Milly, P.C.D., Dunne, K.A., 2017. A Hydrologic Drying Bias in Water-Resource Impact Analyses of Anthropogenic Climate Change. J. Am. Water Resour. Assoc. 53, 822-838. doi:10.1111/1752-1688.12538

Moriasi, D.N., Arnold, J.G., Van Liew, M.W., Bingner, R.L., Harmel, R.D., Veith., T.L., 2007. Model evaluation guidelines for systematic quantifi cation of accuracy in watershed simulations. Trans. ASABE 50, 885-900.

Muerth, M.J., Gauvin St-Denis, B., Ricard, S., Velázquez, J.A., Schmid, J., Minville, M., Caya, D., Chaumont, D., Ludwig, R., Turcotte, R., 2013. On the need for bias correction in regional climate scenarios to assess climate change impacts on river runoff. Hydrol. Earth Syst. Sci. 17, 1189-1204. doi:10.5194/hess-171189-2013

Nash, J.E., Sutcliffe, J. V., 1970. River flow forecasting through conceptual models: Part 1. A discussion of principles. J. Hydrol. 10, 282-290.

Naustdalslid, J., 2011. Climate change - The challenge of translating scientific knowledge into action. Int. J. Sustain. Dev. World Ecol. 18, 243-252. doi:10.1080/13504509.2011.572303

Ochoa-Rivera, J.C., 2008. Prospecting droughts with stochastic artificial neural networks. J. Hydrol. 352, 174-180. doi:10.1016/j.jhydrol.2008.01.006

Ochoa-Rivera, J.C., 2002. Modelo Estocástico de Redes Neuronales para la Síntesis de Caudales Aplicados a la Gestión Probabilística de Sequías. Universitat Politècnica de València.

Paredes-Arquiola, J., Solera, A., Andreu, J., Lerma, N., 2012. Manual técnico de la herramienta EVALHID para la evaluación de recursos hídricos.

Pedro-Monzonís, M., Jiménez-Fernández, P., Solera, A., Jiménez-Gavilán, P., 2016. The use of AQUATOOL DSS applied to the System of Environmental-Economic Accounting for Water (SEEAW). J. Hydrol. 533, 1-14. doi:10.1016/j.jhydrol.2015.11.034

Pérez-Martín, M., Thurston, W., Estrela, T., del Amo, P., 2013. Cambio en las series 
hidrológicas de los últimos 30 años y sus causas. El efecto 80, in: III Jornadas de Ingeniería Del Agua (JIA 2013). La Protección Contra Los Riesgos Hídricos. Valencia, Spain, pp. 527-534.

Sánchez-Quispe, S., Andreu, J., Solera, A., 2001. Gestión de Recursos Hídricos con Decisiones Basadas en Estimación del Riesgo. Universitat Politècnica de València.

Seager, R., Burgman, R., Kushnir, Y., Clement, A., Cook, E., Naik, N., Miller, J., 2008. Tropical pacific forcing of North American medieval megadroughts: Testing the concept with an atmosphere model forced by coral-reconstructed SSTs. J. Clim. 21, 6175-6190. doi:10.1175/2008JCLI2170.1

Stagl, J.C., Hattermann, F.F., 2016. Impacts of Climate Change on Riverine Ecosystems: Alterations of Ecologically Relevant Flow Dynamics in the Danube River and Its Major Tributaries. Water (Switzerland) 8, 566. doi:10.3390/w8120566

Stagl, J.C., Hattermann, F.F., 2015. Impacts of climate change on the hydrological regime of the danube river and its tributaries using an ensemble of climate scenarios. Water (Switzerland) 7, 6139-6172. doi:10.3390/w8120566

Suárez-Almiñana, S., Pedro-Monzonís, M., Paredes-Arquiola, J., Andreu, J., Solera, A., 2017. Linking Pan-European data to the local scale for decision making for global change and water scarcity within water resources planning and management. Sci. Total Environ. 603-604, 126-139. doi:10.1016/j.scitotenv.2017.05.259

Suárez-Almiñana, S., Solera, A., Andreu, J., García-Romero, L., 2020. Uncertainty analysis of climate projections in relation to historical contributions in the Júcar River Basin. Ing. del agua 1-12.

Switanek, B.M., Troch, A.P., Castro, L.C., Leuprecht, A., Chang, H.I., Mukherjee, R., Demaria, M.C.E., 2017. Scaled distribution mapping: A bias correction method that preserves raw climate model projected changes. Hydrol. Earth Syst. Sci. 21, 2649-2666. doi:10.5194/hess-21-2649-2017

Teutschbein, C., Seibert, J., 2013. Is bias correction of regional climate model (RCM) simulations possible for non-stationary conditions. Hydrol. Earth Syst. Sci. 17, 5061-5077. doi:10.5194/hess-17-5061-2013

Teutschbein, C., Seibert, J., 2012. Bias correction of regional climate model simulations for hydrological climate-change impact studies: Review and evaluation of different methods. J. Hydrol. 456-457, 12-29. 
doi:10.1016/j.jhydrol.2012.05.052

Thompson, V., Dunstone, N.J., Scaife, A.A., Smith, D.M., Slingo, J.M., Brown, S., Belcher, S.E., 2017. High risk of unprecedented UK rainfall in the current climate. Nat. Commun. 8, 1-6. doi:10.1038/s41467-017-00275-3

van den Hurk, B., Hewitt, C., Jacob, D., Bessembinder, J., Doblas-Reyes, F., Döscher, R., 2018. The match between climate services demands and Earth System Models supplies. Clim. Serv. 12, 59-63. doi:10.1016/j.cliser.2018.11.002

van den Hurk, B.J.J.M., Bouwer, L.M., Buontempo, C., Döscher, R., Ercin, E., Hananel, C., Hunink, J.E., Kjellström, E., Klein, B., Manez, M., Pappenberger, F., Pouget, L., Ramos, M.H., Ward, P.J., Weerts, A.H., Wijngaard, J.B., 2016. Improving predictions and management of hydrological extremes through climate services. Clim. Serv. 1, 6-11. doi:10.1016/j.cliser.2016.01.001

Vetter, T., Huang, S., Aich, V., Yang, T., Wang, X., Krysanova, V., and Hattermann, F.: Multi-model climate impact assessment and intercomparison for three largescale river basins on three continents, Earth Syst. Dynam., 6, 17-43, https://doi.org/10.5194/esd- 406-17-2015, 2015.

Zambrano-Bigiarini, M., 2020. hydroGOF: Goodness-of-fit functions for comparison of simulated and observed hydrological time series. R Packag. version 0.4-0. doi:doi: 10.5281/zenodo.839854 


\subsection{Efecto del cambio climático en la calidad del agua de la cuenca del Júcar}

Una vez analizado el impacto del cambio climático de forma cuantitativa en los artículos anteriores, hay que centrarse en otro aspecto igualmente importante y complementario, el estado cualitativo de las masas de agua como consecuencia de los cambios experimentados en la cantidad de aportaciones y la temperatura del agua $\left(\mathrm{T}_{\mathrm{a}}\right)$ debido al cambio climático.

Por lo tanto, en este artículo se propone una metodología para analizar el impacto del cambio climático en la calidad del agua de la cuenca del Júcar, ya que AQUATOOL SSD nos permite llevar a acabo estas evaluaciones para todas las masas de agua utilizando sus cadenas de modelos y la información disponible.

En la Fig. 12 se pueden observar todos los pasos para realizar dicho análisis, y para obtener indicadores relacionados, como son los porcentajes de incumplimientos de ciertos contaminantes en los horizontes futuros, teniendo en cuenta las estimaciones futuras de aportaciones y $\mathrm{T}_{\mathrm{a}}$. Esta última variable se considera optativa para modelar la calidad del agua en la mayoría de modelos cualitativos, ya que su uso depende en gran medida de la disponibilidad de datos. Sin embargo, la $\mathrm{T}_{\mathrm{a}}$ puede ser una variable clave en la degradación de algunos contaminantes al condicionar el metabolismo de ciertos microorganismos implicados en este proceso.

Para ello, se utilizó el modelo RREA ya calibrado, uno de los módulos asociados a AQUATOOL SSD, contando con las características físicas de la cuenca del Júcar, así como con las cargas de los contaminantes, aportaciones y otros datos opcionales (en este caso solo la $T_{a}$ ) que se pueden encontrar en el PHDHJ y sus anexos (periodo 1980-2012). 


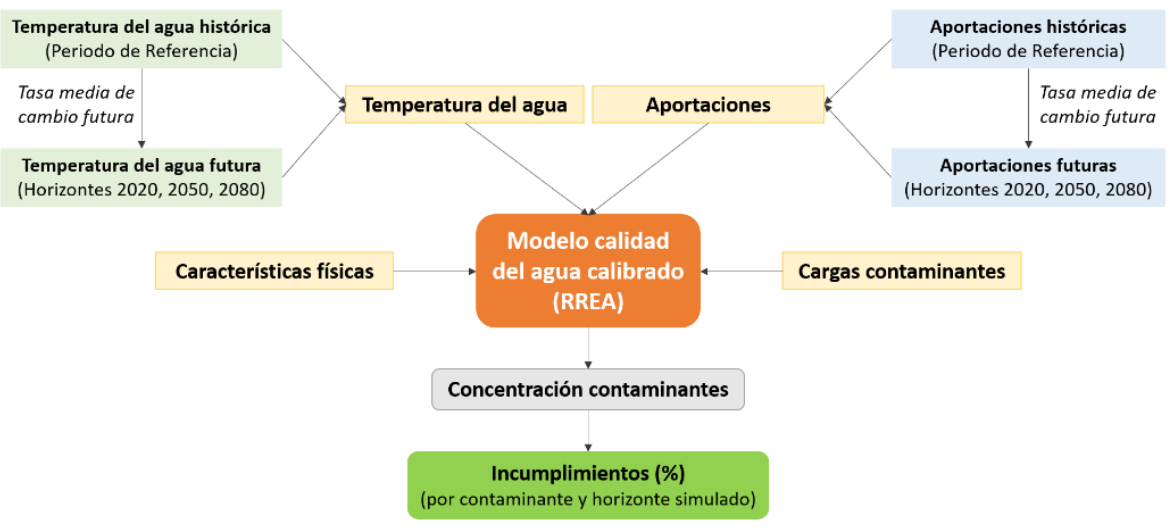

Fig. 12. Metodología para estimar la calidad del agua futura teniendo en cuenta el cambio climático. Fuente: Suárez-Almiñana et al., (2021).

El primer paso de esta metodología es la aplicación de tasas medias de cambio futuras a la $T_{a}$ y las aportaciones históricas de cada masa de agua, con el objetivo de obtener las aportaciones futuras de los horizontes 2020, 2050 y 2080 e integrarlas en el modelo de calidad del agua (RREA). En el caso de las aportaciones, estas tasas provienen de la opción B presentada en Suárez-Almiñana et al., (2020b), ya que se trata de la variante más drástica y estaríamos realizando el análisis para el escenario más complicado. En este caso, se utilizaron las aportaciones históricas provenientes del modelo PARTICAL (Pérez-Martín, 2005), ya que el modelo RREA fue calibrado con ellas al disponer de datos para todas las masas de agua (hasta ahora habíamos trabajado a escala de subcuenca). Finalmente, las tasas de cambio se aplicaron a las masas de agua pertenecientes a cada subcuenca en el periodo de referencia 1980-2010, debido a que un mínimo de 30 años es necesario para garantizar la representatividad estadística de las series futuras según la Organización Meteorológica Mundial (Barranco et al., 2018; Trewin, 2007).

Seguidamente, la $T_{a}$ futura fue obtenida de la misma forma, a partir de tasas medias de cambio por horizonte futuro, esta vez provenientes del servicio climático SWICCA. Estas tasas comparten origen con las utilizadas 
anteriormente, las proyecciones climáticas del modelo E-HYPE para 9 MCR pertenecientes a las SRC 4.5 y 8.5 (Tabla 2).

Una vez obtenidos todos los datos, estos se integran en el modelo para simular la calidad del agua, obteniendo la concentración de los contaminantes que ponen en peligro el buen estado de las masas de agua y sus correspondientes incumplimientos por horizonte futuro. En este caso nos centramos en la $\mathrm{DBO}_{5}$, el $\mathrm{P}$, el $\mathrm{NH}_{4}{ }^{+}$y los $\mathrm{NO}_{3}{ }^{-}$.

Derivado de todos los datos disponibles en la Fig. 12, se pueden extraer los incumplimientos de cada contaminate mediante cuatro simulaciones distintas, una para el periodo de referencia y tres para los horizontes futuros:

1- El periodo de referencia con todos los datos históricos.

2- Horizontes futuros con aportaciones históricas y $T_{a}$ futura.

3- Horizontes futuros con $\mathrm{T}_{\mathrm{a}}$ histórica y aportaciones futuras.

4- Horizontes futuros con $\mathrm{T}_{\mathrm{a}} \mathrm{y}$ aportaciones futuras.

De esta forma, al comparar las simulaciones futuras (2, 3 y 4 ) con la del periodo de referencia (1), se puede estimar la influencia de ambas variables, primero por separado ( 2 y 3) y después de forma conjunta (4), sobre la calidad del agua futura de todas las masas de la cuenca de estudio.

Por lo tanto, mediante la realización de estas simulaciones y su comparación, no solo se pretende relacionar los impactos del cambio climático en las aportaciones futuras con los propios de la calidad del agua, sino también evaluar la importancia de la $T_{a}$ en la degradación de algunos contaminantes.

Los principales resultados indican que las masas de agua afectadas en la actualidad podrían experimentar afecciones más graves en el futuro debido al cambio climático, con mayores afecciones en los horizontes 2050 y 2080 y en las partes media y baja de la cuenca. En este último caso debido a altas 
concentraciones de $\mathrm{NO}_{3}^{-}$, procedentes sobre todo de las actividades agrícolas. Los contaminantes que mostraron mayor dependencia de la $T_{a}$ en su degradación fueron la $\mathrm{DBO}_{5}$ y el $\mathrm{NH}_{4}{ }^{+}$, por lo que se aconseja integrar la $\mathrm{T}_{\mathrm{a}}$ en este tipo de simulaciones para evitar subestimar o sobrestimar afecciones futuras.

Por último, también es necesario señalar que la herramienta RREA proporcionó una visión global del estado futuro de la cuenca, teniendo en cuenta sus simplificaciones a efectos de modelación y las incertidumbres inherentes de las proyecciones climáticas. De esta visión, hay que destacar el hallazgo de algunas masas de agua afectadas no analizadas previamente, por lo que este estudio también puede servir de toque de atención en zonas no evaluadas, para integrarlas en campañas de mediciones futuras y en la toma de medidas a pequeña escala. Todo ello con el fin de evitar problemas en el suministro y demás problemas socioeconómicos y ambientales asociados a una mala calidad del agua.

A continuación, se puede ver la versión de autor del siguiente artículo, con el permiso de todos los coautores:

Suárez-Almiñana, S., Paredes-Arquiola, J., Andreu, J., Solera, A. (2021). Efecto del cambio climático en la calidad del agua de la Cuenca del Júcar. Ingeniería del agua, 25(2), 215-235. https://doi.org/10.4995/la.2021.14644

\section{Efecto del cambio climático en la calidad del agua de la Cuenca del Júcar}

\section{Climate change effect on water quality in the Júcar River Basin}

Sara Suárez-Almiñana ${ }^{\mathrm{a} 1}$, Javier Paredes-Arquiola ${ }^{\mathrm{a} 2}$, Joaquín Andreu ${ }^{\mathrm{a} 3}$ y Abel Solera ${ }^{\mathrm{a} 4}$ 
anstituto universitario de Ingeniería del Agua y Medio Ambiente (IIAMA), Universitat Politècnica de València (UPV), Camino de Vera s/n, CP: 46022, Valencia, España.

E-mail: ${ }^{a 1}$ sasual@upv.es, a2jparedea@hma.upv.es, ${ }^{a 3}$ ximoand@upv.es, a4asolera@upv.es

\section{RESUMEN}

En este estudio se analiza el efecto del cambio climático en la calidad del agua de la cuenca del Júcar a partir de estimaciones futuras de aportaciones hidrológicas y temperatura del agua (Ta). Para ello, se utilizó un modelo de calidad de aguas a escala de cuenca con el que se estimó el estado ecológico de todas las masas de agua, basándose en las concentraciones de $\mathrm{DBO}_{5}, \mathrm{P} \mathrm{NH}_{4}{ }^{+}$y $\mathrm{NO}_{3}{ }^{-}$para los horizontes futuros 2020 , 2050 y 2080.

De este análisis se obtuvo un incremento del número de masas con altos niveles de contaminación ( $80 \%-100 \%$ incumplimientos) en los horizontes 2050 y 2080, localizadas sobre todo en la parte media y baja de la cuenca. Además, la degradación de la $\mathrm{DBO}_{5}$ y el $\mathrm{NH}_{4}{ }^{+}$es muy dependiente de la temperatura del agua, poniendo de manifiesto la importancia de considerar esta variable en el modelo.

Palabras clave | estado ecológico; tasa de cambio futura; temperatura del agua; RREA; incumplimientos.

\section{ABSTRACT}

This study analyses the effect of climate change on water quality in the Júcar River Basin from future estimations of hydrological inputs and water temperature (WT). For this purpose, a large-scale water quality model was used to estimate the ecological status of all the water bodies, based on the concentrations of $\mathrm{BDO}_{5}, \mathrm{P} \mathrm{NH}_{4}{ }^{+}$y NO${ }_{3}^{-}$for the future horizons 2020, 2050 and 2080. 
In this study, a greater number of water bodies with higher pollution levels (80-100\% failures) were obtained in the horizons 2050 and 2080, which are located in the middle and lower parts of the basin. In addition, the degradation of $\mathrm{BDO}_{5}$ and the $\mathrm{NH}_{4}{ }^{+}$is highly dependent on WT, highlighting the importance of considering this variable in the model.

Key words I ecological status; future change rate; water temperature; RREA; failures.

\section{INTRODUCCIÓN}

La influencia del ser humano sobre los recursos del planeta ha generado diversos problemas a escala global, ya que el consumo de estos recursos naturales suele ir acompañado de sobreexplotación y contaminación, causando la degradación de los ecosistemas (Pellicer-Martínez y MartínezPaz, 2016).

Uno de los mayores problemas asociados es la aceleración del cambio climático, derivado sobre todo del consumo excesivo de hidrocarburos (IPCC, 2014). Este fenómeno afecta a gran parte de los sistemas naturales y su equilibrio, como es el caso del ciclo del agua, relacionado con el ámbito de los recursos hídricos.

En la actualidad, algunas zonas del planeta ya se encuentran afectadas por la escasez de recursos hídricos y su contaminación, que se puede ver acrecentada por el efecto del cambio climático a pesar de contar con sistemas integrales y robustos de gestión y planificación hidrológica. En este sentido, si nos enmarcamos a nivel europeo, existen regulaciones al respecto, como la ampliamente conocida Directiva Marco del Agua (EP, 2000) que se incluye en la regulación de todos los países miembros con el fin de tomar medidas para proteger las aguas y garantizar así su sostenibilidad, tanto en términos cuantitativos como cualitativos. 
Además, en las últimas décadas también se ha incluido la obligatoriedad de analizar el impacto del cambio climático sobre este tipo de recursos en varias normativas a escala europea y estatal. Ejemplo de ello es su análisis en los Planes Hidrológicos de las grandes cuencas españolas, derivado de otros informes publicados por organismos científicos, como el del CEDEX (2017) sobre el impacto del cambio climático en los recursos hídricos y sequías en las cuencas más importantes de España. En el citado estudio, se prevé una disminución de las aportaciones (i.e. caudales) generalizada, sobre todo en el sur y el este del país, y el aumento en intensidad y duración de eventos extremos como la sequía.

Este tipo de estudios se pueden desarrollar gracias a los servicios climáticos, que proporcionan series temporales e indicadores provenientes de proyecciones climáticas a nivel global, europeo o nacional, como los proporcionados por CORDEX (Coordinated Regional Climate Downscaling Experiment), el SMHI (Swedish Meteorological and Hydrological Institute) y AEMET (Agencia Estatal de Meteorología de España), respectivamente. Sin embargo, la incertidumbre asociada a estas proyecciones es muy elevada, sobre todo en la vertiente mediterránea (Suárez-Almiñana et al., 2017; Marcos-Garcia y Pulido-Velazquez, 2017; Barranco et al., 2018; SuárezAlmiñana et al., 2020a), lo que puede implicar que los resultados de estos estudios sean tomados con cautela a la hora de incluirlos en la toma de decisiones (Lemos and Rood, 2010; Naustdalslid, 2011).

Por otra parte, la mayoría de estos estudios se centran casi exclusivamente en el análisis cuantitativo de los recursos, dejando de lado la parte cualitativa (Serpa et al., 2017; Jong-Suk et al., 2019; Rocha et al., 2020) a pesar de su relación directa y del amplio abanico de modelos que combinan su simulación a diferentes escalas, tanto temporales como espaciales (Arnold et al., 1998; Whitehead et al., 1998; Pérez-Martín, 2005). Por este motivo, el principal objetivo de este estudio es relacionar estos dos aspectos y estimar los posibles impactos del cambio climático en la calidad del agua para una mejor gestión integral de la cuenca, lo que conlleva una 
toma de decisiones anticipada guiada por una evaluación de impacto más holística. Esta toma de decisiones podría evitar los fallos en los suministros y las enormes pérdidas económicas e impactos sociales y ambientales procedentes del mal estado (tanto cuantitativo como cualitativo) de las masas de agua.

En este sentido, también es interesante cuantificar la influencia de la temperatura del agua ( $\mathrm{Ta}$ ) en las concentraciones de los contaminantes en el medio natural, ya que algunos de ellos (p. ej. amonio) dependen de la acción de microorganismos para su degradación, cuyo metabolismo se acelera o ralentiza dependiendo de los valores de esta variable (Ahmad et al., 2021; Zlatanović et al., 2017).

Además de ser un factor limitante para la vida de algunas especies (Wang et al., 2020), la Ta tiene una gran influencia en las propiedades y procesos que ocurren en el agua, como la solubilidad de gases y sales, entre muchos otros. Ejemplo de ello es la concentración de oxígeno disuelto, que disminuye con el aumento de la Ta, condicionando la capacidad de autodepuración de las masas de agua y produciendo desajustes en el ecosistema (mortalidad de peces, malos olores, etc.) (Pellicer-Martínez and Martínez-Paz, 2016; Wang et al., 2020; Xu et al., 2012). Estos desajustes también pueden estar relacionados con ciertos contaminantes provenientes del ciclo del nitrógeno, lo que puede llevar a la proliferación excesiva de masa vegetal y causar problemas de eutrofización en masas y embalses (Xu et al., 2012).

El caso de estudio seleccionado para cumplir con estos objetivos fue la cuenca del Júcar (este de España), caracterizada por su gran variabilidad hidrológica y tener problemas de calidad del agua relacionados sobre todo con materia orgánica y nutrientes. Como consecuencia del cambio climático en esta zona, se prevé una reducción de los caudales circulantes y, por ello, una menor capacidad de dilución de los vertidos (Rocha et al., 2020; Serpa et al., 2017), afectando negativamente a la calidad del agua en el futuro. Por otro lado, también se prevé un aumento de la Ta, que debería favorecer 
las cinéticas de degradación de los contaminantes, incrementándose la capacidad de autodepuración de las masas de agua. El efecto global sobre la calidad del agua de la reducción del recurso hídrico y el aumento de la Ta variará en función de la tipología de masa de agua, pero se espera que el efecto combinado de estas variables se pueda predecir con antelación y así prevenir los efectos nocivos del cambio climático en cuanto al empeoramiento del estado ecológico de las masas de agua.

\section{MATERIAL Y MÉTODOS}

En esta sección, primero se presenta el caso de estudio y el estado actual de la calidad de sus masas de agua. Seguidamente, se introduce una metodología general para estimar la calidad del agua futura y su adaptación a la cuenca del Júcar, especificando los datos de entrada y las características del modelo de calidad del agua utilizado.

\section{Caso de estudio}

La cuenca del Júcar se encuentra en la parte este de España y es el sistema de explotación más importante de la Demarcación Hidrográfica del Júcar (DHJ) en cuanto a superficie $\left(22359 \mathrm{~km}^{2}\right)$ y recursos hídricos generados (media de $1798.3 \mathrm{hm}^{3} /$ año en la serie histórica 1940-2012, media de 1605.4 hm³/año en la serie histórica 1980-2012) (CHJ, 2015). El río principal de este sistema es el Júcar (512 km), que desemboca en el mar Mediterráneo y tiene como principales afluentes a los ríos Cabriel, Magro y Albaida (Figura 1).

Además, una de las características principales de esta cuenca es su gran variabilidad hidrológica, propia del clima mediterráneo, con precipitaciones (P) medias de $475.2 \mathrm{~mm} /$ año, temperatura $(\mathrm{T})$ media de $14.2^{\circ} \mathrm{C}, \mathrm{y}$ evapotranspiración potencial (ETP) media de $926.6 \mathrm{~mm} /$ año (CHJ, 2015). 


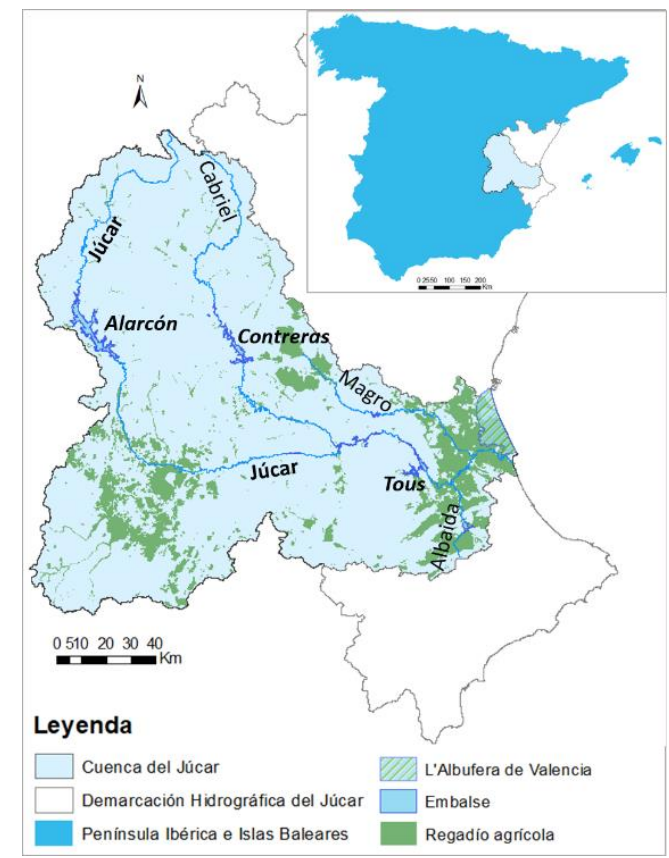

Figura 1 | Localización de la cuenca del Júcar en España y la DHJ con algunas de sus características principales.

Este es un sistema complejo, no solo por la gran variabilidad espacial y temporal en la distribución de las aportaciones, sino también por estar sujeto a una gran presión antrópica. Como se puede apreciar en la Figura 2, esta presión se debe principalmente a la actividad agrícola, localizada tanto en la zona media como en la zona costera de la cuenca, donde también se encuentra l'Albufera de Valencia, un humedal de 21120 ha compuesto por un lago y una gran extensión de arrozales.

En su regulación juegan una labor fundamental los embalses de Alarcón, Contreras y Tous, que suman una capacidad de $1796 \mathrm{hm}^{3}$ y combinan su uso y abastecimiento de agua con recursos subterráneos procedentes del acuífero de La Mancha Oriental (parte media de la cuenca) y de La Plana de Valencia (zona costera). 
Por lo tanto, se trata de un sistema altamente regulado, tanto para hacer frente a las grandes demandas del sistema ( $80 \%$ uso agrícola y $20 \%$ otros usos, incluyendo el urbano) como a los fenómenos extremos, entre los que se pueden mencionar las sequías (con rachas plurianuales) y las inundaciones, relacionadas sobre todo con el fenómeno de la DANA (Depresión Atmosférica aislada en Niveles Altos) durante el periodo otoñal.

Todas estas presiones no solo afectan a los recursos de la cuenca de manera cuantitativa, sino también cualitativamente, lo que puede suponer fallos en los suministros o elevados costes de tratamiento de aguas, entre otros problemas socio-económicos y ambientales, ya considerados en el Plan Hidrológico de la Demarcación Hidrográfica del Júcar (PHDHJ) (CHJ, 2015), desarrollado por la Confederación Hidrográfica del Júcar (CHJ).

Por todo esto, en este artículo se decidió relacionar los impactos en las aportaciones derivados del cambio climático con los de la calidad del agua y así tener una visión global de la cuenca para el futuro. Para ello, primero observaremos el estado actual de las masas de agua en la siguiente sección.

\section{Estado actual de la calidad de las masas de agua}

La Figura 2 muestra las 140 masas de agua de esta cuenca, sus numeraciones y la subcuenca a la que pertenecen.

En estas masas, la $\mathrm{CHJ}$ realiza mediciones periódicas (mensuales o trimestrales) para evaluar su estado, teniendo en cuenta la concentración de contaminantes relacionados con aportes de materia orgánica y nutrientes (entre otros), cuya degradación puede ser de forma química o biológica. Algunos de estos contaminantes son: la Demanda Biológica de Oxígeno al quinto día $\left(\mathrm{DBO}_{5}\right)$, el fósforo $(\mathrm{P})$, el amonio $\left(\mathrm{NH}_{4}{ }^{+}\right)$y los nitratos $\left(\mathrm{NO}_{3}{ }^{-}\right)$. 


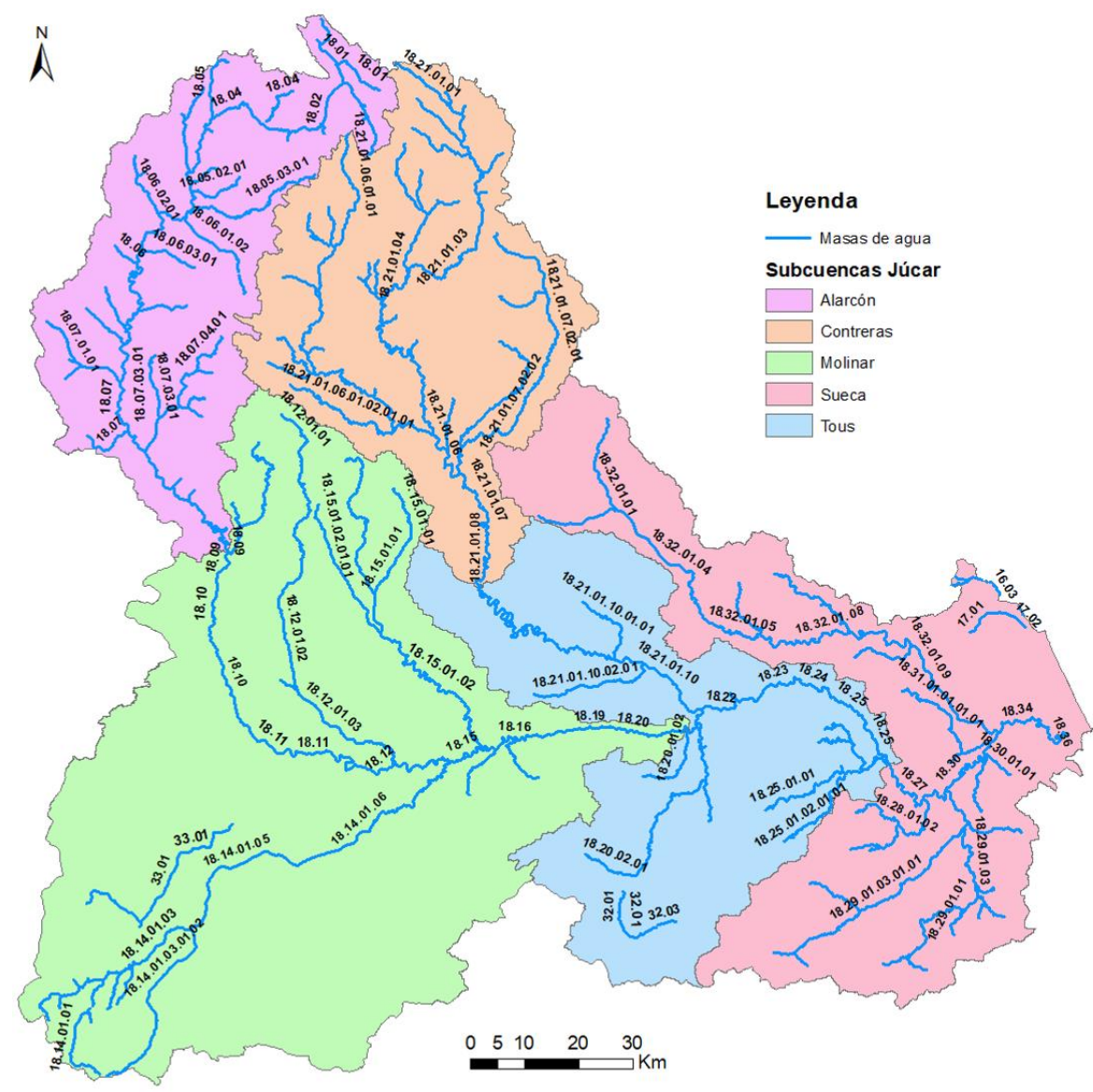

Figura 2 | Masas de agua de la cuenca del Júcar y la subcuenca a la que pertenecen (CHJ, 2015).

En la Figura 3 se informa sobre qué masas de agua se encuentran impactadas por cada contaminante, las no impactadas y las no evaluadas por la CHJ. Los umbrales de concentración a partir de los cuales se considera una masa impactada se establecen en el Real Decreto 815/2015 (BOE, 2015) y en el PHDHJ (CHJ, 2015). Estos son: $\mathrm{DBO}_{5}=6 \mathrm{mg} / \mathrm{l}, \mathrm{P}=0.4$ $\mathrm{mg} / \mathrm{l}, \mathrm{NH}_{4}{ }^{+}=0.6 \mathrm{mg} / \mathrm{l}$ y $\mathrm{NO}_{3}{ }^{-}=25 \mathrm{mg} / \mathrm{l}$. En nuestro estudio para evaluar el impacto sobre las masas de agua se utiliza el porcentaje de meses en que las concentraciones son superiores a estos límites. Estos meses se denominan incumplimientos. 

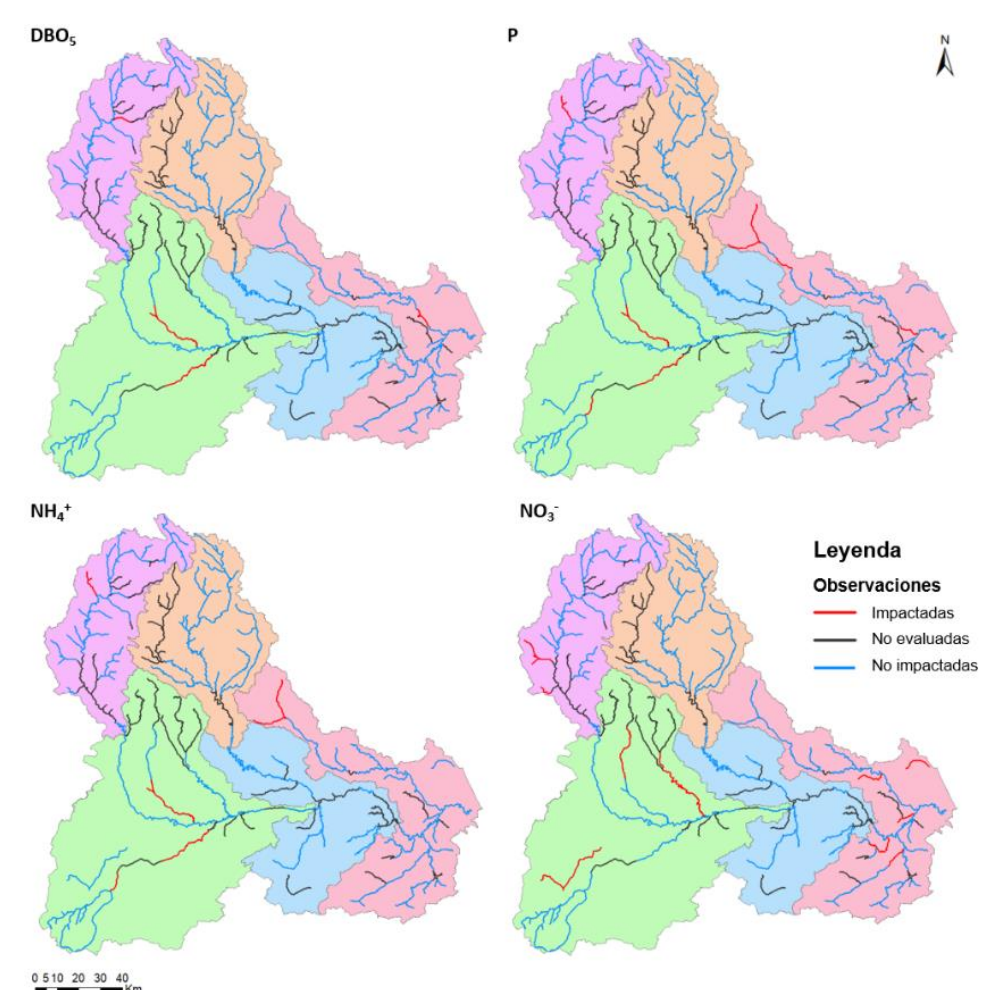

Figura 3 | Masas de agua impactadas, no evaluadas y no impactadas basadas en las observaciones de la $(\mathrm{CHJ}, 2015)$ en la cuenca del Júcar para la $\mathrm{DBO}_{5}$, el $\mathrm{P}$, el $\mathrm{NH}_{4}{ }^{+}$y los $\mathrm{NO}_{3}$.

De las 140 masas, 39 de ellas no están evaluadas, ya sea porque no se consideró necesario, o por inaccesibilidad, falta de fondos u otras razones. De las 101 masas restantes, 4 de ellas se encuentran impactadas debido a concentraciones elevadas de $\mathrm{DBO}_{5}, 8$ de ellas en el caso del $\mathrm{P}, 5$ en el caso del $\mathrm{NH}_{4}{ }^{+}$y 12 en el de los $\mathrm{NO}_{3}{ }^{-}$. En todos los casos, las subcuencas de Contreras y Tous no se ven afectadas, sin embargo, Molinar parece ser la subcuenca más afectada por todos los contaminantes, y Sueca en el caso de los $\mathrm{NO}_{3}^{-}$.

En términos generales, las masas de agua afectadas por $\mathrm{P}$ también lo están por $\mathrm{NH}_{4}{ }^{+}$, y algunas de ellas por la $\mathrm{DBO}_{5}$. Sin embargo, el caso de los $\mathrm{NO}_{3}{ }^{-}$difiere de los anteriores. 
Debido a la gran cantidad de masas no evaluadas y el elevado coste que esto supondría, se hace necesario un método que permita disponer de una estimación de su situación. Por ello se propone el uso de un modelo de calidad del agua a gran escala que permita evaluar el nivel de contaminación de las masas de agua y su situación en escenarios de cambio climático.

\section{Metodología general}

El primer paso de esta metodología (Figura 4) es la recopilación de los datos de entrada al modelo de calidad del agua. Aparte de las características físicas, las cargas de los contaminantes y las aportaciones de cada masa de agua, existe la opción de incluir otros datos opcionales para realizar la simulación. Estos datos están relacionados con los caudales ecológicos, las demandas de agua, los caudales observados de cada masa de agua (para corregir los caudales de entrada) y la Ta, cuya integración en el modelo depende sobre todo de la disponibilidad de datos. En este caso sí se ha considerado esta última variable, ya que, aparte de disponer de la Ta histórica, se hace imprescindible en este proceso por su influencia en la degradación de algunos contaminantes.

Para estimar el efecto del cambio climático en la calidad del agua, también se necesitan estimaciones futuras, tanto de aportaciones como de $\mathrm{Ta}$, en este caso. Estas estimaciones se obtienen mediante la aplicación de tasas medias de cambio futuras a los datos de Ta y aportaciones históricas de cada masa de agua. Estas tasas de cambio se pueden obtener gracias a los servicios climáticos por medio de las proyecciones climáticas o derivadas de ciertos estudios relevantes a escala nacional o de cuenca. Normalmente, se consideran tres horizontes futuros compuestos de periodos de 30 años (como mínimo) hasta finales de siglo, correspondiendo con un periodo futuro cercano, uno medio y uno lejano (Barranco et al., 2018).

Una vez aplicadas las tasas de cambio, se obtiene la Ta y aportaciones futuras para cada horizonte, que se introducen junto con los otros datos 
(características físicas y cargas contaminantes actuales) en el modelo de calidad del agua, ya preparado y calibrado para ello. En este trabajo, se ha utilizado un modelo a gran escala llamado RREA (Respuesta Rápida del Estado Ambiental) (Paredes-Arquiola, 2014), cuyas características principales se detallan en la siguiente sección.

Como resultado de la simulación de este modelo, se obtiene la concentración de los contaminantes que ponen en peligro el buen estado de las masas de agua y sus correspondientes incumplimientos (\%) por periodo u horizonte.

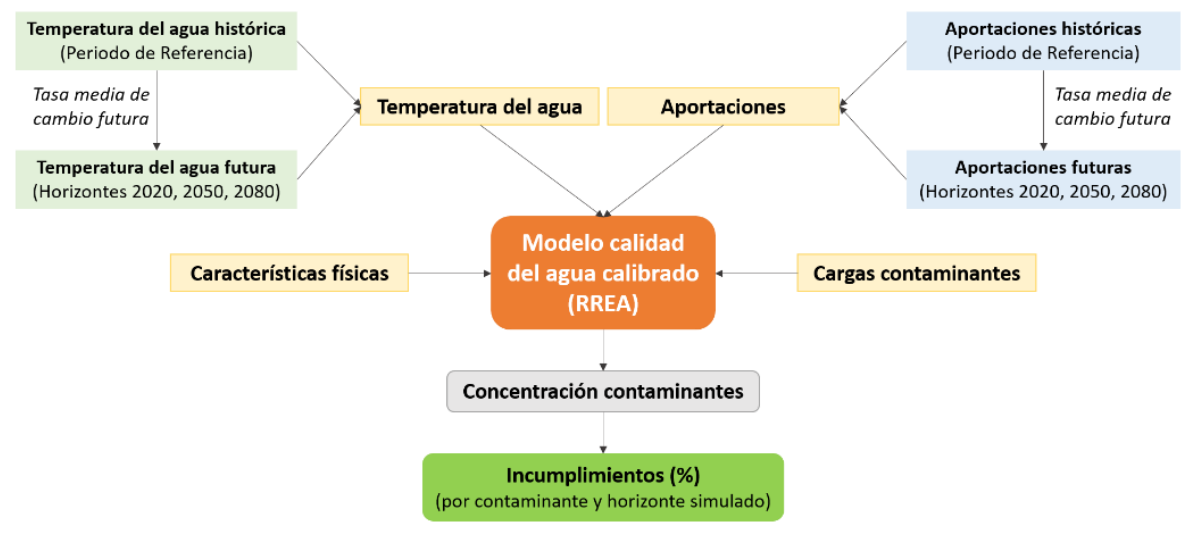

Figura 4 | Metodología de modelado de la calidad del agua teniendo en cuenta la Ta y aportaciones futuras para la obtención del estado ecológico de las masas de agua por medio de porcentajes de incumplimiento para cada contaminante y horizonte simulado.

Así pues, y gracias a la posibilidad de modificar dos de las variables de entrada por sus estimaciones futuras, es posible realizar cuatro simulaciones diferentes para identificar los posibles problemas de calidad del agua a los que habría que hacer frente en el futuro. Primero se simula el periodo de referencia utilizando los datos históricos de todas las variables y seguidamente se procede a las tres simulaciones restantes: i) integrando la Ta futura, ii) integrando las aportaciones futuras e iii) integrando tanto la Ta como las aportaciones futuras. De esta forma, al comparar los incumplimientos de las tres simulaciones con las del periodo de referencia 
es posible evaluar el efecto de ambas variables (por separado y de forma combinada) sobre la calidad del agua, por contaminante y horizonte futuro.

\section{Modelo RREA}

Para desarrollar el modelo de calidad del agua se utilizó la herramienta RREA, que estima las concentraciones de contaminantes en las masas de agua superficiales teniendo en cuenta la carga de contaminantes introducida en cada masa de agua, la contaminación procedente de aguas arriba y la degradación que se produce en la propia masa, utilizando como base la siguiente ecuación:

$$
M_{e, i}=M_{g e n, i}+\sum_{j=1}^{n} M_{s, j}(j \rightarrow i)
$$

Donde, $\mathrm{M}_{\mathrm{e}, \mathrm{i}}$ es la masa de contaminante que entra en la masa de agua $\mathrm{i}$; $M_{\text {gen.i }}$ es la masa de contaminante generada en la propia cuenca de la masa $\mathrm{i}, \mathrm{y}_{\mathrm{s}, \mathrm{j}}(\mathrm{j} \rightarrow \mathrm{i})$ es la masa de contaminante de salida de todos las masas de agua $\mathrm{j}$ que vierten a la masa $\mathrm{i}$.

A continuación, se simula la degradación de los contaminantes según una ecuación cinética de primer orden:

$$
M_{s, i}=M_{e, i} \cdot e^{-K L}
$$

Donde $\mathrm{M}_{\mathrm{s}, \mathrm{i}}$ es la masa de contaminante que sale de la masa de agua i; $\mathrm{K}$ es la constante de degradación del contaminante en la masa i; L es la longitud de la masa de agua.

Y se calcula la concentración de contaminante $\left(C_{i}\right)$ para el caudal de salida $\left(Q_{s, i}\right)$ :

$$
C_{i}=\frac{M_{s, i}}{Q_{s, i}}
$$

Por lo tanto, los resultados principales que proporciona el modelo para cada masa de agua son: caudales $\left(\mathrm{hm}^{3} / \mathrm{mes}\right)$, concentración de 
contaminantes a la salida $(\mathrm{mg} / \mathrm{l})$ y porcentajes de fallos por superación de los umbrales de concentración de los contaminantes a la salida (\%) en cada masa de agua, los incumplimientos. Se puede encontrar más información sobre este modelo y su formulación en: https://aquatool.webs.upv.es/files/manuales/rrea/ManualT\%C3\%A9cnico ModeloRREA_V3.pdf.

Respecto a las constantes de degradación por masa de agua y contaminante $\left(\mathrm{km}^{-1}\right.$ en ríos y $\mathrm{d}^{-1}$ en embalses), sus valores se fijan en el proceso de calibración, que se lleva a cabo en un proceso iterativo de prueba y error a partir de constantes bajas que se incrementan en aquellas masas de agua con altas concentraciones. Estas constantes se mantienen dentro de rangos aconsejables en la bibliografía, como los sugeridos por Bowie et al. (1985) y Flynn et al. (2015), pero dependen de otros factores relacionados con las condiciones ambientales, sean o no modificadas por la acción antrópica (Ferrer y Seco, 2008), como la Ta, considerada como la más importante en el desarrollo del fenómeno hídrico (Gutiérrez y de Jalón, 1999).

La influencia de esta variable se puede observar en la siguiente ecuación (Bowie et al., 1985; Ferrer y Seco, 2008):

$$
K_{T}=K_{20} \cdot \vartheta^{(T a-20)}
$$

Dónde: $\mathrm{K}_{\mathrm{T}}$ y $\mathrm{K}_{20}$ son las constantes cinéticas de degradación a Ta y $20^{\circ} \mathrm{C}$, respectivamente; $\vartheta$ es el coeficiente de corrección de la temperatura.

Tanto el desarrollo inicial del modelo como su calibración fueron realizados de forma conjunta entre investigadores de la UPV y miembros de la administración de la $\mathrm{CHJ}$ como parte de los trabajos de Planificación Hidrológica para el ciclo 2021-27, no formando parte del ámbito de este estudio. 


\section{Datos de entrada del modelo RREA}

Los datos de entrada al modelo fueron proporcionados principalmente por la $\mathrm{CHJ}$, como las masas de agua identificadas por código, su longitud, la masa de agua a la que descargan y el orden de flujo, la carga de contaminantes producida por los vertidos puntuales $(\mathrm{kg} / \mathrm{mes})$ y las series de aportaciones históricas. Todos ellos se pueden encontrar en el PHDHJ y en sus anejos de presiones e impactos.

Los contaminantes considerados en este estudio son la $\mathrm{DBO}_{5}$, el $\mathrm{P}$, el $\mathrm{NH}_{4}{ }^{+}$y los $\mathrm{NO}_{3}{ }^{-}$, basándonos en sus porcentajes de incumplimientos mensuales como principales resultados, cuyos umbrales de concentración se encuentran en el apartado "Estado actual de la calidad de las masas de agua". Este modelo considera las relaciones entre los contaminantes estudiados y los procesos implicados, como los del balance del nitrógeno, por lo que el amonio que se nitrifica pasa a ser nitrato.

En cuanto a las aportaciones históricas, estas proceden del modelo PATRICAL ("Precipitación Aportación en Tramos de Red Integrado con CALidad del agua"; Pérez-Martín, 2005) en régimen natural. Este modelo de precipitación-escorrentía es un modelo quasi-distribuido $(1 \mathrm{~km} \times 1 \mathrm{~km})$ que funciona a grandes escalas espaciales y temporales (50-100 años) considerando la calidad del agua. Además, funciona a escala mensual y utiliza la formulación de Témez (1977) en cada celda, basada en mapas de $\mathrm{P}$ y ETP calculados mediante la interpolación de los valores de P y T de las estaciones meteorológicas (Pérez-Martín, 2005).

Para obtener las aportaciones futuras, en este caso se utilizaron las tasas medias de cambio de aportaciones obtenidas por Suárez-Almiñana et al., (2020b), procedentes del desarrollo de una metodología de integración de proyecciones climáticas para la planificación hidrológica. En el citado estudio, se trabajó con la media del ensamblado compuesto por 9 Modelos Climáticos Regionales pertenecientes a las Sendas Representativas de Concentración (SRC) 4.5 y 8.5, ya que según lo acordado en la cumbre de 
cambio climático de Paris de 2015, la SRC más probable es un escenario intermedio entre estos dos, la SRC 6.0 (Barranco et al., 2018; SuárezAlmiñana et al., 2020a; Suárez-Almiñana et al., 2020b). Por lo tanto, estas tasas medias proceden de la corrección del sesgo de las aportaciones futuras (procedentes de un modelo hidrológico) y su comparación con las del periodo histórico (1980-2000), extrayendo así las tasas medias de cambio para cada horizonte. El periodo histórico utilizado se puede considerar equivalente en recursos hídricos al de la serie "corta" 1980-2012 (Suárez-Almiñana et al., 2020a).

Así pues, para evaluar el efecto del cambio climático en la calidad de las masas de agua, estas tasas medias de cambio por subcuenca, mes (año medio) y horizonte futuro $(2020,2050$ y 2080) se aplicaron a cada una de las aportaciones de cada masa de agua en el periodo histórico 1980-2010, ya que según la Organización Meteorológica Mundial, para que un estudio sea estadísticamente representativo cada horizonte tiene que tener como mínimo 30 años (Trewin, 2007; Barranco et al., 2018).

En esta ocasión, también consideramos la Ta en la simulación debido a la disponibilidad de datos. La Ta histórica fue proporcionada por la $\mathrm{CHJ}$ y la futura se encuentra disponible en el portal del proyecto SWICCA (Service for Water Indicators in Climate Change Adaptation, www.swicca.eu), un proyecto Copernicus liderado por el SMHI que pone a disposición de los usuarios variables climáticas, hidrológicas, socioeconómicas, de calidad y cantidad del agua, indicadores, mapas, etc. provenientes de proyecciones climáticas relacionadas con los recursos hídricos a nivel europeo. Estos datos también se presentan en tasas de cambio por horizonte futuro (diferenciando entre la media del ensamblado o SRC) y comparten origen con las proyecciones climáticas utilizadas para la extracción de las tasas de cambio aplicadas a las aportaciones en este estudio (Suárez-Almiñana et al., 2020b).

Como resultado de la aplicación de las tasas medias de cambio de aportaciones mensuales por masa de agua y horizonte (procedentes de 
Suárez-Almiñana et al., 2020b), se obtuvieron unos cambios medios en toda la cuenca del $6 \%$ en el horizonte $2020,-2 \%$ en el 2050 y - $12 \%$ en el 2080.

Por otro lado, el promedio anual del ensamblado de la Ta resultante para cada horizonte y subcuenca se muestra en la Tabla 1 , donde se puede observar cómo la Ta aumenta en las diferentes subcuencas en función de los horizontes futuros. El promedio anual para toda la cuenca en el periodo de referencia es de $14.8^{\circ} \mathrm{C}$, para el horizonte 2020 es de $15.8^{\circ} \mathrm{C}$, y para 2050 y 2080 son de $16.4^{\circ} \mathrm{C}$ y $17.2^{\circ} \mathrm{C}$, respectivamente. Por lo tanto, con respecto al periodo de referencia, la Ta aumentaría en $0.9^{\circ} \mathrm{C}$ en el futuro cercano, $1.6^{\circ} \mathrm{C}$ en el futuro medio y $2.4^{\circ} \mathrm{C}$ en el futuro lejano.

Tabla 1 | Temperatura del agua media $\left({ }^{\circ} \mathrm{C}\right)$ para el periodo de referencia (PR) y cada horizonte futuro $(2020,2050,2080)$, por subcuenca y para toda la cuenca del Júcar.

\begin{tabular}{|c|c|c|c|c|c|c|}
\cline { 2 - 7 } \multicolumn{1}{c|}{} & Alarcón & Contreras & Molinar & Tous & Sueca & Cuenca del Júcar \\
\hline PR & 13.2 & 12.8 & 15.1 & 16 & 17.2 & $\mathbf{1 4 . 8}$ \\
\hline $\mathbf{2 0 2 0}$ & 14.1 & 13.6 & 16.2 & 16.8 & 18.1 & $\mathbf{1 5 . 8}$ \\
\hline $\mathbf{2 0 5 0}$ & 14.7 & 14.3 & 17.1 & 17.4 & 18.7 & $\mathbf{1 6 . 4}$ \\
\hline $\mathbf{2 0 8 0}$ & 15.4 & 15 & 18.1 & 18.1 & 19.5 & $\mathbf{1 7 . 2}$ \\
\hline
\end{tabular}

Seguidamente, las aportaciones y la Ta del período de referencia y las obtenidas para los horizontes futuros fueron introducidas en el modelo RREA para simular la calidad del agua en esta cuenca. Los resultados obtenidos en cada aplicación se detallan en la siguiente sección.

\section{RESULTADOS Y DISCUSIÓN}

En esta sección se presentan los resultados procedentes de las cuatro simulaciones nombradas en "Metodología general" y su discusión. Primero se introducen los del periodo de referencia y después los de cambio climático, aportando mapas y figuras sobre los incumplimientos, el número de masas afectadas y el grado de afectación por contaminante, horizonte y simulación. 


\section{Simulación del periodo de referencia}

En la Figura 5 se pueden observar los incumplimientos de cada contaminante en el período de referencia. Las masas de agua 18.15.01.02, 18.14.01.06 y 18.12.01.02 de la subcuenca de Molinar son las más afectadas en el caso de la $\mathrm{DBO}_{5}$. Las dos primeras se encuentran en el rango de incumplimientos entre el $80 \%$ - 100\%, mientras que la tercera está entre el $60 \%-80 \%$. Estos niveles de afectación se podrían deber a los numerosos vertidos de naturaleza urbana (saneamiento población) que hay en estas masas, además de algunos vertidos industriales relacionados con la industria vinícola y el almacenamiento de gasóleo con lavado de vehículos (Figura 1, "Material suplementario").

Por otra parte, las subcuencas de Contreras y Tous no se ven especialmente afectadas (0\% - 20\%) y los incumplimientos son menores en las subcuencas de Alarcón y Sueca, donde solo una masa de cada una de ellas (la 18.07.04.03 y la 18.29.01.02, respectivamente) se encuentra en el rango $40 \%-60 \%$.

Las masas con incumplimientos más elevados (80\% - 100\%) para el P se presentan en las mismas masas de Molinar. Por el contrario, no se observan afecciones relevantes en las otras subcuencas, únicamente las masas 18.07.03.01 y 18.07 .04 .03 (Alarcón) presentan entre el $20 \%$ - $40 \%$ de incumplimientos.

También en el caso del $\mathrm{NH}_{4}{ }^{+}$las masas de Molinar son las más afectadas al encontrarse en los intervalos $60 \%-80 \%$ y $80 \%-100 \%$. En este caso también se observan algunas masas entre el $40 \%$ - $60 \%$ de incumplimientos en Alarcón (18.07.03.01, 18.07.04.03) y Sueca (18.32.01.03, 18.29.01.02), pero las masas más afectadas de Sueca son las 18.32 .01 .02 y 18.29.01.02, en el rango $60 \%-80 \%$. 

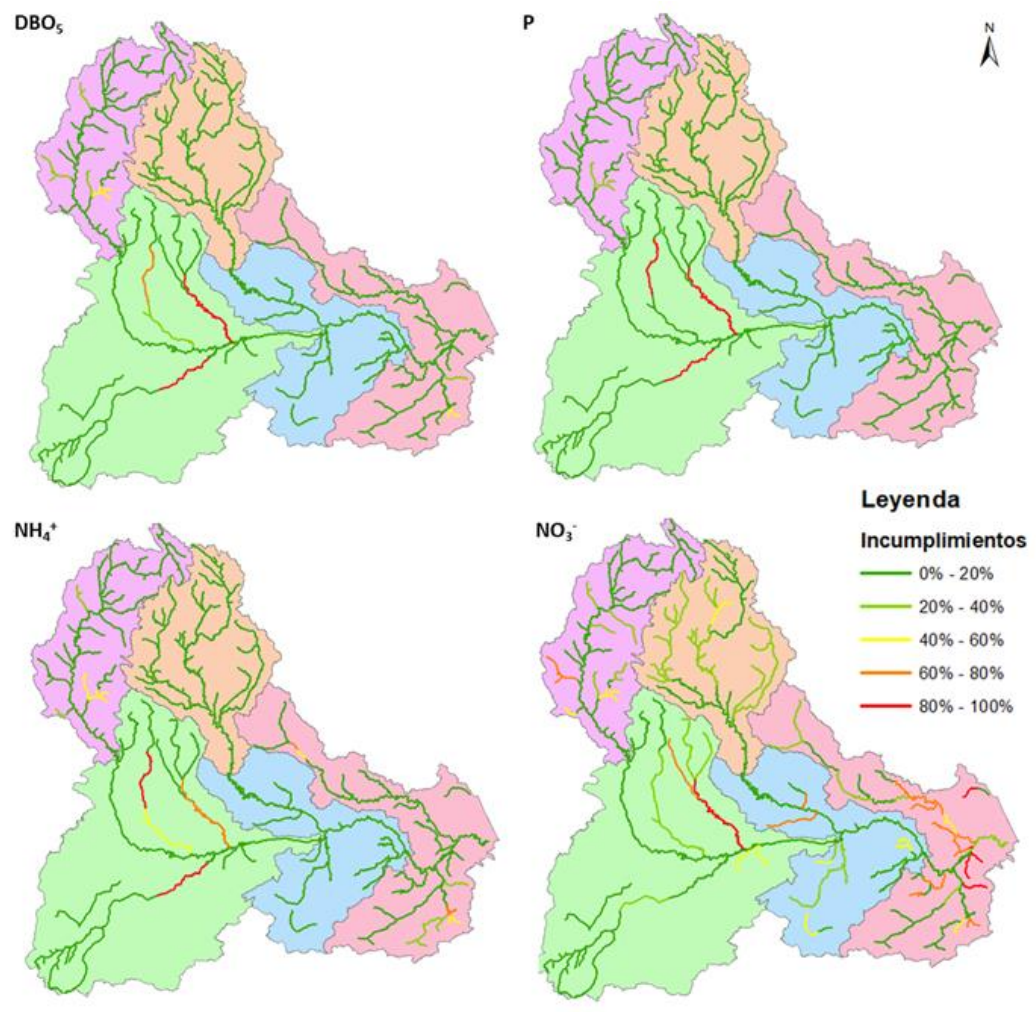

$0.51020 \quad 30 \quad 40$

Figura 5 | Masas afectadas por contaminante $\left(\mathrm{DBO}_{5}, \mathrm{P}, \mathrm{NH}_{4}{ }^{+}\right.$y $\left.\mathrm{NO}_{3}{ }^{-}\right)$en el periodo de referencia (1980-2010) teniendo en cuenta la Ta histórica, donde las afecciones se estiman en porcentaje de incumplimientos de los contaminantes.

Sin embargo, el caso de los $\mathrm{NO}_{3}{ }^{-}$difiere de los anteriores por presentar afecciones en todas las subcuencas, en mayor o menor medida. En este caso, la subcuenca de Sueca es la más afectada, con la mayoría de las masas entre los intervalos $60 \%-80 \%$ y $80 \%$ - $100 \%$. Además, la mayoría de la subcuenca de Contreras se encuentra en el rango $20 \%-40 \%$ y en Alarcón destaca la masa de agua 18.07.01.01 en el rango 60\%-80\%, (coincidiendo con la Figura 3 en afectación). En el mismo rango (60\%-80\%) se encuentran las masas 18.21.01.10.02.01 y 18.21.01.10 de la subcuenca de Tous, que en la Figura 3 aparecen como no evaluadas. Por otra parte, en Molinar destaca la masa 18.15.01.02 dentro del rango de incumplimientos más elevado. 
La afección más amplia de este contaminante podría deberse a la influencia de la agricultura, ya que las zonas donde se desarrolla esta actividad (Figura 1) coinciden con las masas más contaminadas. El ejemplo más claro de esta influencia se encuentra en la parte baja de la cuenca donde se sitúa l'Albufera de Valencia y la gran extensión de cultivos de arroz. Además, en esta zona hay una gran concentración de vertidos urbanos y algunos industriales relacionados con el comercio de frutas $y$ hortalizas, procesado de legumbres y cereales, granjas avícolas y otros relacionados con la fabricación de vehículos, pinturas y barnices (Figura 1, "Material suplementario").

Así pues, excluyendo el caso de los nitratos, las mayores afecciones se dan sobre todo en la subcuenca de Molinar.

Además, al comparar las Figura 3 y Figura 5, se observa que la mayoría de las masas impactadas coinciden con las de tasas de incumplimientos superiores al $20 \%$. Sin embargo, algunas masas no coincidentes presentan altos porcentajes de afectación (como la 18.15.01.02 en Molinar), lo que puede derivar de medidas adoptadas no incluidas en el modelo o datos deficientes, entre otras razones.

También se observa cómo algunas masas no evaluadas se ven afectadas, como las pertenecientes a las subcuencas de Contreras, Tous y Molinar en el caso de los nitratos, lo que indica que se deberían hacer más muestreos y estudiarlas en profundidad en futuras campañas.

\section{Simulaciones de cambio climático}

En la Figura 6 se representa el número de masas de agua pertenecientes a cada intervalo de incumplimientos por contaminante, simulación y horizonte. 


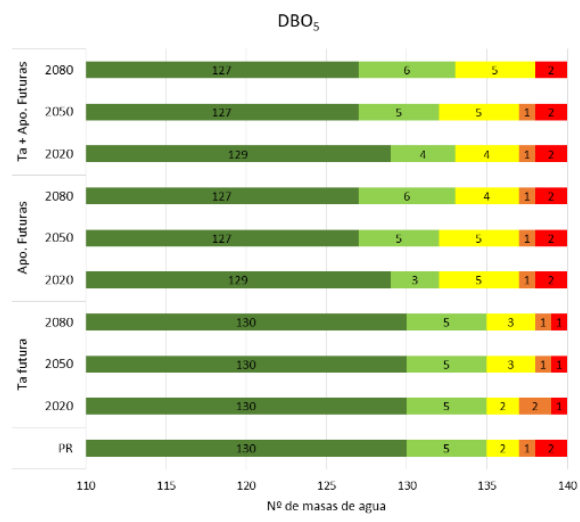

$\mathrm{NH}_{4}{ }^{+}$

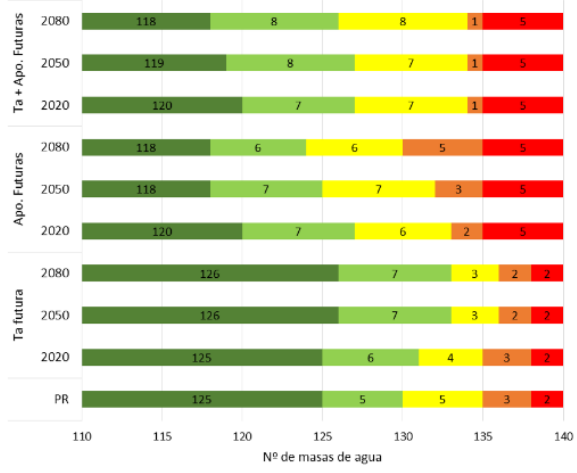

$=0 \%-20 \% \quad=20 \%-40 \% \quad=40 \%-60 \% \quad=60 \%-80 \% \quad=80 \%-100 \%$
$P$

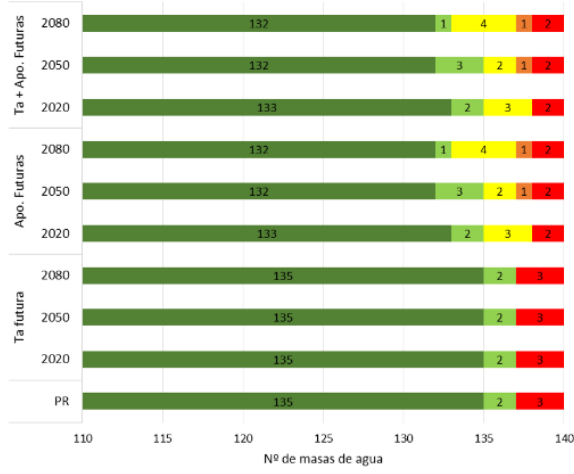

$\mathrm{NO}_{3}$

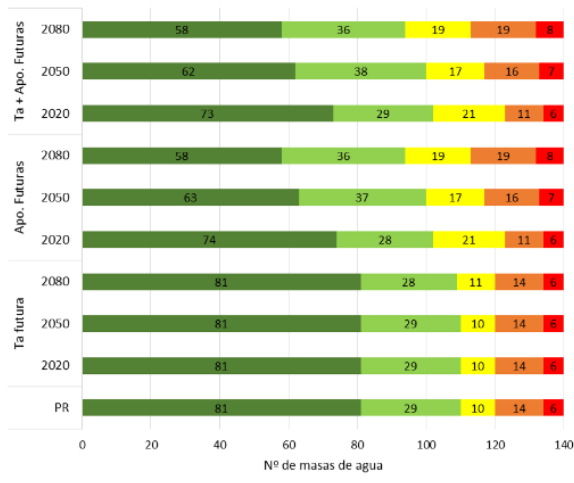

Figura 6 | Número de masas de agua en cada intervalo de incumplimiento por contaminante $\left(\mathrm{DBO}_{5}, \mathrm{P}, \mathrm{NH}_{4}{ }^{+}\right.$y $\left.\mathrm{NO}_{3}{ }^{-}\right)$, simulación (periodo de referencia - $\mathrm{PR}$, Ta futura, Apo. Futuras o la combinación de ambas - Ta + Apo. Futuras) y horizonte futuro (2020, 2050 y 2080).

Si nos centramos en la simulación de la Ta futura (Figura 6, parte baja) y se compara con la del periodo de referencia, se observa un comportamiento diferente dependiendo de los contaminantes, mientras que en el caso del $\mathrm{P}$ y de los $\mathrm{NO}_{3}{ }^{-}$el número de masas de agua se mantiene en cada intervalo de incumplimientos, en el caso de la $\mathrm{DBO}_{5}$ y el $\mathrm{NH}_{4}{ }^{+}$ algunas de las masas más afectadas sí sufren cambios, principalmente bajando de rango conforme aumenta la Ta en los diferentes horizontes.

Este efecto también se observa en la Figura 7, donde se resaltan las diferencias entre los incumplimientos de los horizontes futuros y los del 
periodo de referencia en esta simulación (Ta futura) para la $\mathrm{DBO}_{5}$ y el $\mathrm{NH}_{4}^{+}$. De esta forma se puede apreciar si los incumplimientos se mantienen, disminuyen o aumentan en el futuro.

En el caso de la $\mathrm{DBO}_{5}$, se ve como algunas de las masas de Alarcón, Molinar y Sueca han sufrido un pequeño descenso (0\% - -10\%) en los incumplimientos del horizonte 2020, donde destaca la masa 18.15.01.02 (Molinar) con una disminución del $15 \%$, que se incrementa a $29 \%$ en el 2050 y a $32 \%$ en el 2080. Además, las masas 18.12 .01 .02 y 18.12 .01 .03 de la misma subcuenca también presentan cambios significativos entre horizontes, alcanzando ambas una disminución de incumplimientos del 13\% en el futuro lejano.

En el caso del $\mathrm{NH}_{4}{ }^{+}$, también se registraron pequeños descensos que se mantienen a lo largo de los horizontes futuros, con la excepción de unas pequeñas masas en la subcuenca de Sueca y la masa 18.15.01.02 de Molinar. Esta última destaca por sus descensos más pronunciados, alcanzando disminuciones del $17 \%$ y el $24 \%$ en el futuro medio y lejano respectivamente.

Estos resultados indican que la degradación de la $\mathrm{DBO}_{5}$ y el $\mathrm{NH}_{4}{ }^{+}$es muy dependiente de la $\mathrm{Ta}$, ya que experimentan menores incumplimientos con el aumento de la Ta, es decir, a más Ta, más degradación (Serpa et al., 2017).

Por el contrario, en el caso de los $\mathrm{NO}_{3}{ }^{-}$(Figura 2, "Material suplementario") se producen aumentos de los incumplimientos, sobre todo en las masas ya nombradas de Molinar, aunque estos aumentos no son lo suficientemente elevados $(<10 \%)$ como para pasar de rango de afectación en la Figura 6. Esto se debe a la relación entre el amonio y los nitratos, ya que forman parte de un mismo ciclo. Las tasas de disminución de incumplimientos del amonio observadas al aumentar la Ta podrían estar relacionadas con los aumentos en los incumplimientos de los nitratos, ya que la rápida degradación del amonio implica el aumento de concentración 
de nitritos que inmediatamente se convierten en nitratos que permanecen libres para la asimilación de las plantas.

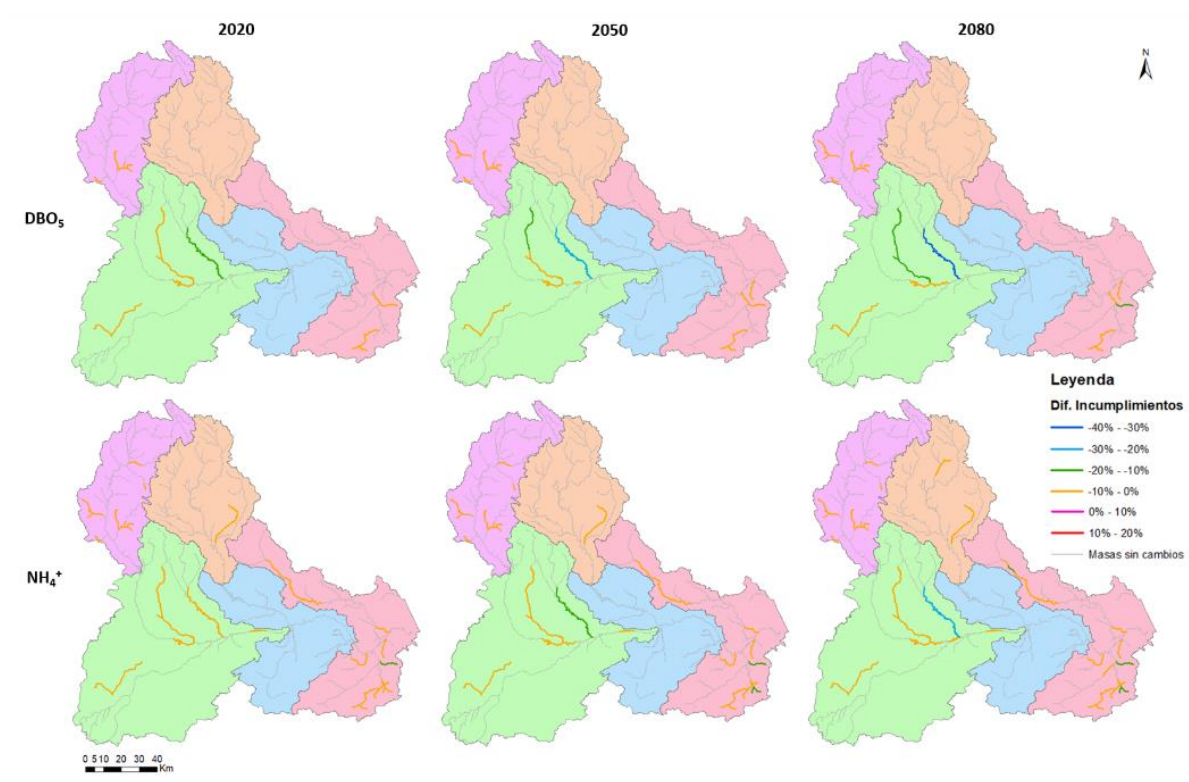

Figura 7 | Diferencia entre los incumplimientos de los horizontes futuros (2020, 2050 y 2080) y los del periodo de referencia (Figura 5 ) en la simulación de la Ta futura para la $\mathrm{DBO}_{5}$ y el $\mathrm{NH}_{4}{ }^{+}$.

En cambio, las diferencias de las afectaciones estimadas en la simulación de las aportaciones futuras son más notables en el caso de todos los contaminantes (Figura 6, parte media). En términos generales, se estima un mayor número de masas afectadas en los intervalos con mayores incumplimientos al avanzar entre horizontes, sobre todo en el caso del $\mathrm{NH}_{4}{ }^{+}$ y los $\mathrm{NO}_{3}^{-}$, donde el número de masas con mayores afecciones se incrementa notablemente. 


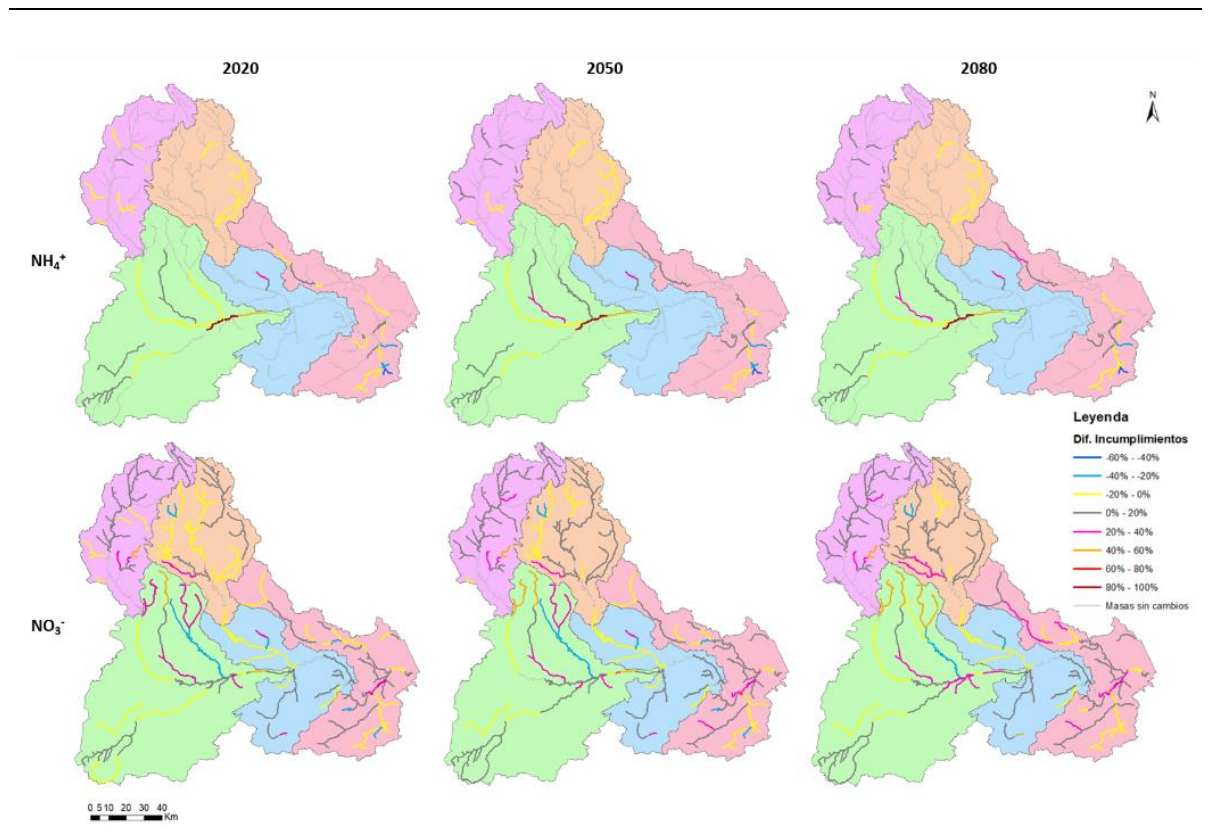

Figura 8 | Diferencia entre los incumplimientos de los horizontes futuros (2020, 2050 y 2080) y los del periodo de referencia (Figura 5) en la simulación de las aportaciones futuras para el $\mathrm{NH}_{4}^{+}$y los $\mathrm{NO}_{3}$.

En la Figura 8 se muestran ambos casos, donde hay algunas masas que sufren pequeños descensos en 2020, algo lógico si tenemos en cuenta que las tasas medias de cambio se incrementaban este horizonte en la mayoría de las subcuencas, permitiendo así una mayor dilución de los contaminantes. Sin embargo, también se estiman algunos incrementos preocupantes que se mantienen o incrementan en los horizontes sucesivos. En el caso del $\mathrm{NH}_{4}{ }^{+}$, destacan las masas de Molinar, sobre todo la 18.15 y la 18.16 con los incrementos más elevados, cerca de un $95 \%$ en todos los horizontes. La masa 18.12.01.03 (Molinar) también experimenta un aumento progresivo hasta llegar a aumentar en un $24 \%$ respecto de los incumplimientos del periodo de referencia, junto a otras pequeñas masas de Tous y Sueca posicionadas en el mismo intervalo de cambios $(20 \%-40 \%)$ en el futuro lejano. 
En el caso de los $\mathrm{NO}_{3}{ }^{-}$ocurre algo similar, pero con más masas afectadas por los cambios en todas las subcuencas, aunque la mayoría de ellos son entre el $|0 \%-20 \%|$ en el futuro cercano, estos se van incrementando poco a poco en los sucesivos horizontes. Sin embargo, la mayoría de estos aumentos no son muy elevados $(<10 \%)$, lo que provoca que la mayoría de masas se queden en los mismos intervalos de incumplimientos. Lo mismo ocurre con la $\mathrm{DBO}_{5}$ (Figura 3, "Material suplementario"), donde las diferencias entre los incumplimientos de los horizontes futuros no son muy significativas, ya que las principales masas de agua afectadas (Molinar) permanecen en los mismos intervalos de incumplimientos hasta finales de siglo.

Por último, el caso del P (Figura 3, "Material suplementario") es similar los anteriores, con algunos descensos de incumplimientos a partir de 2020, probablemente debido al incremento de los recursos en este horizonte, cuyas afectaciones se incrementa ligeramente en los horizontes más lejanos (Figura 6). La cuenca más afectada sigue siendo Molinar.

Cuando se estima el efecto combinado de ambas variables (Figura 6, parte alta), solo se experimentan cambios evidentes en los resultados de la $\mathrm{DBO}_{5}$ y el $\mathrm{NH}_{4}{ }^{+}$, ya que la degradación de los otros contaminantes (Figura 4, "Material suplementario") parecen no estar influenciados por la Ta y por lo tanto sus resultados no difieren de los de la simulación anterior (aportaciones futuras).

En la Figura 9 se observa como las mayores diferencias siguen presentándose en la subcuenca de Molinar para ambos contaminantes de esta simulación combinada, donde el efecto de la Ta (disminuciones Figura 7) frena el incremento de incumplimientos procedente de la disminución de recursos (Figura 8), sobre todo en el caso del $\mathrm{NH}_{4}{ }^{+}$(Figura 6).

En el caso de la $\mathrm{DBO}_{5}$, la mayoría de masas siguen en los mismos intervalos de afectación durante todos los horizontes, aunque las masas 18.15.01.02 y 18.12.01.03 de Molinar Ilaman la atención por los enormes 
descensos experimentados, probablemente provocados por el aumento de Ta y la mayor aportación de recursos en el horizonte 2020. Por otro lado, las masas 18.15 y 18.16 de la misma subcuenca se encuentran altamente afectadas (80\% - 100\%). Estas masas con una afectación inaceptable también destacan en el caso del $\mathrm{NH}_{4}{ }^{+}$, junto a pequeños aumentos de incumplimientos graduales hasta finales de siglo en las subcuencas de Alarcón y Sueca. En cambio, también se observan mayores descensos a futuro de la masa 18.15.01.02 (Molinar) por la gran influencia ejercida por la Ta, a pesar de los incrementos observados en la Figura 8.
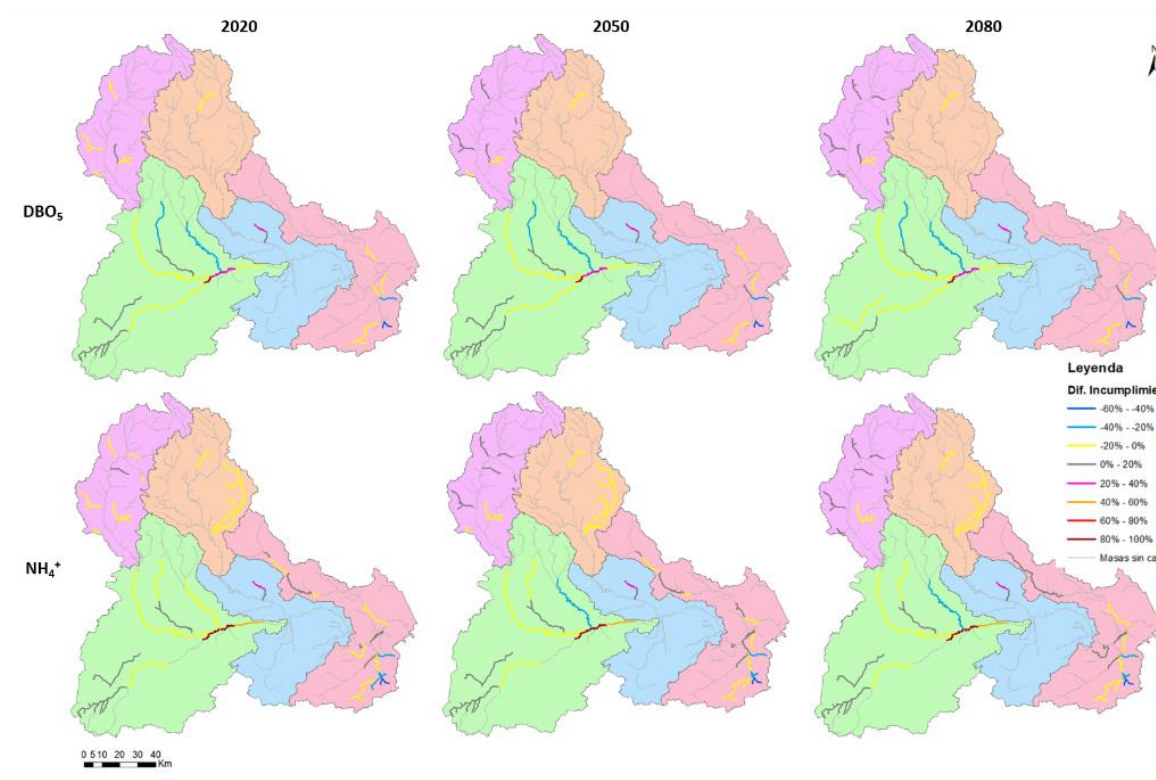

Figura 9 | Diferencia entre los incumplimientos de los horizontes futuros (2020, 2050 y 2080) y los del periodo de referencia (Figura 5) en la simulación de la Ta y las aportaciones futuras para la $\mathrm{DBO}_{5}$ y el $\mathrm{NH}_{4}^{+}$.

Todos estos resultados se podrían resumir en una relación directa entre la reducción futura de los recursos disponibles y mayores afectaciones de las masas de agua de la cuenca del Júcar, presentando mayor número de masas afectadas en mayores intervalos de incumplimientos de contaminantes entre los horizontes 2050 y 2080. Esta relación se debe 
principalmente a la menor capacidad de dilución que presentan las masas de agua al reducirse sus aportaciones (Serpa et al., 2017; Rocha et al., 2020), que se ve amortiguada por la mayor degradación experimentada por algunos contaminantes al aumentar la Ta, pudiendo obtener menores niveles de afectación en algunas de las masas más afectadas debido a su efecto combinado.

Por este motivo, se hace necesaria la inclusión de la Ta en la simulación de la $\mathrm{DBO}_{5}$ y el $\mathrm{NH}_{4}{ }^{+}$siempre que sea posible, ya que su degradación depende en gran medida de estos valores y su consideración podría marcar la diferencia a la hora de detectar futuros problemas de calidad de agua en masas no evaluadas.

Sin embargo, hay que tener en cuenta que en este estudio se han utilizado aportaciones producto de la aplicación de tasas medias de cambio a un periodo histórico, y aunque han sido obtenidas por medio de proyecciones climáticas, estos datos tienen mucha incertidumbre asociada, que además va aumentando en la cadena de modelos (Suárez-Almiñana, et al., 2020b). También, hemos utilizado un modelo simplificado en el que los porcentajes de incumplimientos corresponden a los promedios de la serie histórica y de los horizontes futuros, que quizás estén condicionadas por los periodos de sequía y los meses de verano, en los que algunos cauces carecen de agua.

Entre esta incertidumbre también hay que considerar que se ha simulado con las características actuales del sistema, no considerando otros posibles cambios a futuro. En este sentido, la simulación se podría mejorar considerando otras variables como: escenarios socioeconómicos relacionados con la demanda futura (Shared Socioeconomic Pathways SSP) (Jin et al., 2018; Hunink et al., 2019), ya que esto afecta a la carga de contaminante; tasas de reducción de la demanda agrícola relacionadas con la modernización de los cultivos (Hunink et al., 2019); cambios en los usos del suelo (Serpa et al., 2017; Shrestha et al., 2018); los caudales ecológicos 
o mayores restricciones ambientales, entre otros. Aunque estos aportes también podrían ser fuentes potenciales de incertidumbre.

Por último, decir que este estudio se puede considerar como una señal de alerta ante lo que podría ocurrir en el futuro de la cuenca del Júcar si no se toman medidas de adaptación al cambio climático, ya que debido a sus efectos sobre los recursos hídricos y la Ta podría haber graves problemas de contaminación en los ríos de esta cuenca, afectando a la gestión eficaz de los recursos hídricos y acarreando graves problemas ambientales y socioeconómicos.

\section{CONCLUSIONES}

Mediante la estimación de la Ta y aportaciones futuras por medio de tasas medias de cambio y su integración en el modelo de calidad del agua RREA para la cuenca del Júcar, se ha demostrado que las masas de agua afectadas en la actualidad podrían experimentar afecciones más graves en el futuro debido al cambio climático. En general, Molinar es la subcuenca que podría verse más afectada en el futuro por todos los contaminantes estudiados, junto con la subcuenca de Sueca en el caso de los nitratos, al estar sometida a una mayor actividad agrícola. Además, las afecciones más drásticas se dan en los horizontes 2050 y 2080 , donde el número de masas afectadas en rangos de porcentajes de incumplimientos elevados $(60 \%$ $100 \%)$ es preocupante.

Por otro lado, en este estudio también se ha estimado la influencia de la Ta en la degradación de algunos contaminantes $\left(\mathrm{DBO}_{5}\right.$ y $\left.\mathrm{NH}_{4}{ }^{+}\right)$, por lo que se aconseja integrar esta variable en este tipo de simulaciones siempre que sea posible, evitando así subestimar o sobrestimar afecciones.

Con esta herramienta se da una visión global del estado futuro de la cuenca, considerando las limitaciones que se adquieren al emplear un modelo simplificado y la incertidumbre propia de las proyecciones climáticas. En este sentido, aparte de analizar los incrementos en los 
incumplimientos de los contaminantes, también se han detectado las zonas más afectadas y algunas masas de agua no analizadas que aparecen afectadas, por lo que este método puede servir de apoyo en el proceso de toma de decisiones a la hora de localizar los principales focos de contaminación, proponer actuaciones a pequeña escala e intentar solucionarlos a largo plazo para no poner en riesgo el suministro, con todos los problemas ambientales y socio-económicos que esto podría acarrear.

\section{AGRADECIMIENTOS}

Los autores agradecen al Ministerio de Ciencia e Innovación (MICINN) por financiar el proyecto RESPHIRA (PID2019-106322RB-100) y a la Agencia Estatal de Investigación (MINECO) por financiar el proyecto ERAS (CTM2016-77804-P), cofinanciado con Fondos FEDER. Además, también valoramos el apoyo de la Comunidad Europea en la financiación de los proyectos IMPREX (H2020-WATER-2014-2015, 641811) y SWICCA (ECMRWF-Copernicus-FA 2015/ C3S_441-LOT1/SMHI). Por último, agradecer al Programa de Apoyo para la Investigación y Desarrollo (PAID01-17) de la Universitat Politècnica de València por fomentar y facilitar los contratos de formación de personal investigador.

\section{REFERENCIAS}

Ahmad, J.I., Dignum, M., Liu, G., Medema, G., van der Hoek, J.P., 2021. Changes in biofilm composition and microbial water quality in drinking water distribution systems by temperature increase induced through thermal energy recovery. Environmental Research 194, 110648. doi: 10.1016/j.envres.2020.110648

Arnold, J.G., Srinivasan, R., Muttiah, R.S., Williams, J.R., 1998. Large area hydrologic modeling and assessment Part I: Model development. Journal of the American Water Resources Association 34, 73-89. doi: 10.1111/j.17521688.1998.tb05961.x.

Barranco, L., Dimas, M., Jiménez, A., Estrada, F., 2018. Nueva evaluación del impacto futuro del cambio climático en los recursos hídricos en España. Ingeiría Civil 191/2008, 34-55. 
BOE, 2015. Real Decreto 817/2015, de 11 de septiembre, por el que se establecen los criterios de seguimiento y evaluación del estado de las aguas superficiales y las normas de calidad ambiental, Actualidad Jurídica Ambiental.

Bowie, G.L., Mills, W.B., Porcella, D.B., Campbell, C.L., Pagenkopf, J.R., Rupp, G.L., Johnson, K.M., Chan, P.W.H., Gherini, S.A., Chamberlin, C.E., 1985. Rates, Constants, and Kinetics Formulations in Surface Water Quality Modeling. EPA/600/3-. Athens, Georgia: U.S. Environmental Protection Agency.

CEDEX, 2017. Evaluación Del Impacto Del Cambio Climático En Los Recursos Hídricos y Sequías de España. Informe técnico para el Ministerio de Agricultura y Pesca, Alimentación y Medio Ambiente. Madrid, España.

CHJ, 2015. Plan Hidrológico de la Demarcación Hidrográfica del Júcar. Memoria ciclo de planificación hidrológica 2015-2021. Ministerio de Agricultura, Alimentación y Medio Ambiente. Valencia, España.

EP (European Parliament). 2000. Directive 2000/60/EC of the European Parliament and of the Council of 23 October 2000 Establishing a Framework for Community Action in the Field of Water Policy. Brussels: Official Journal.

Ferrer, J., Seco, A., 2008. Tratamientos Biológicos de Aguas Residuales. Valencia, España: Universidad Politécnica de Valencia : Alfaomega Grupo Editor.

Flynn, K.F., Suplee, M.W., Chapra, S.C., Tao, H., 2015. Model-Based Nitrogen and Phosphorus (Nutrient) Criteria for Large Temperate Rivers: 1. Model Development and Application. Journal of the American Water Resources Association 51 (2): 421-46. doi: 10.1111/jawr.12253.

Gutiérrez, B., de Jalón, D.G., 1999. Modelización térmica de los ríos Cea y Manzanares. Limnetica 17, 1-12.

Hunink, J., Simons, G., Suárez-Almiñana, S., Solera, A., Andreu, J., Giuliani, M., Zamberletti, P., Grillakis, M., Koutroulis, A., Tsanis, I., Schasfoort, F., Contreras, S., Ercin, E., Bastiaanssen, W., 2019. A Simplified Water Accounting Procedure to Assess Climate Change Impact on Water Resources for Agriculture across Different European River Basins. Water 11, 1976. doi: 10.3390/w11101976.

IPCC, 2014. Climate Change 2014: Synthesis Report. Contribution of Working Groups I, II and III to the Fifth Assessment Report of the Intergovernmental Panel on Climate Change [Core Writing Team, R.K. Pachauri and L.A. Meyer (eds.)]. IPCC, Geneva, Switzerland, 151 pp. doi: 10.1017/CBO9781107415324. 
Jin, L., Whitehead, P.G., Rodda, H., Macadam, I., Sarkar, S., 2018. Simulating climate change and socio-economic change impacts on flows and water quality in the Mahanadi River system, India. Science of the Total Environment 637-638: 907-17. doi: 10.1016/j.scitotenv.2018.04.349.

Jong-Suk, K., Shaleen, J., Joo-Heon, L., Hua, C., Seo-Yeon, P., 2019. Quantitative vulnerability assessment of water quality to extreme drought in a changing climate. Ecological Indicators 103 (March): 688-97. doi: 10.1016/j.ecolind.2019.04.052.

Lemos, M.C., Rood, R.B., 2010. Climate Projections and Their Impact on Policy and Practice. Wiley Interdisciplinary Reviews: Climate Change 1 (5): 670-82. doi: 10.1002/wcc.71.

Marcos-Garcia, P., Pulido-Velazquez, M., 2017. Cambio Climático y Planificación Hidrológica: ¿es Adecuado Asumir Un Porcentaje Único de Reducción de Aportaciones Para Toda La Demarcación? Ingeniería del Agua 21 (1): 35. doi: 10.4995/ia.2017.6361.

Naustdalslid, J., 2011. Climate change - The challenge of translating scientific knowledge into action. International Journal of Sustainable Development and World Ecology 18 (3): 243-52. doi: 10.1080/13504509.2011.572303.

Paredes-Arquiola, J., 2021. Manual Técnico Del Modelo Respuesta Rápida Del Estado Ambiental (RREA) de Masas de Agua Superficiales Continentales. Universitat Politècnica de València. Valencia, España. https://aquatool.webs.upv.es/files/manuales/rrea/ManualT\%C3\%A9cnicoMo deloRREA_V3.pdf.

Pellicer-Martínez, F., Martínez-Paz, J.M., 2016. The Water Footprint as an Indicator of Environmental Sustainability in Water Use at the River Basin Level. Science of the Total Environment 571: 561-74. doi: 10.1016/j.scitotenv.2016.07.022.

Pérez-Martín, M.., 2005. Modelo distribuido de simulación del ciclo hidrológico con calidad de aguas integrado en sistemas de información geográfica para grandes cuencas. Aportación al análisis de presiones e impactos de la Directiva Marco Europea del Agua. Universidad Politécnica de Valencia. Valencia, España.

Rocha, J., Carvalho-Santos, C., Diogo, P., Beça, P., Keizer, J.J., Nunes, J.P., 2020. Impacts of climate change on reservoir water availability, quality and irrigation needs in a water scarce Mediterranean region (southern Portugal). Science of the Total Environment 736. doi: 10.1016/j.scitotenv.2020.139477. 
Serpa, D., Nunes, J.P., Keizer, J.J., Abrantes, N., 2017. Impacts of climate and land use changes on the water quality of a small Mediterranean catchment with intensive viticulture. Environmental Pollution 224: 454-65. doi: 10.1016/j.envpol.2017.02.026.

Shrestha, S., Bhatta, B., Shrestha, M., Shrestha, P.K., 2018. Integrated assessment of the climate and landuse change impact on hydrology and water quality in the Songkhram River Basin, Thailand. Science of the Total Environment 643: 1610-22. doi: 10.1016/j.scitotenv.2018.06.306.

Suárez-Almiñana, S., Pedro-Monzonís, M., Paredes-Arquiola, J., Andreu, J., Solera, A., 2017. Linking Pan-European data to the local scale for decision making for global change and water scarcity within water resources planning and management. Science of the Total Environment 603-604: 126-39. doi: 10.1016/j.scitotenv.2017.05.259.

Suárez-Almiñana, S., Solera, A., Andreu, J., García-Romero, L., 2020a. Análisis de incertidumbre de las proyecciones climáticas en relación a las aportaciones históricas en la Cuenca del Júcar. Ingeniería del Agua 1-12. doi: 10.4995/ia.2020.12149.

Suárez-Almiñana, S., Solera, A., Madrigal, J., Andreu, J., Paredes-arquiola, J., 2020b. Risk assessment in water resources planning under climate change at the Júcar River Basin. Hydrology and Earth System Science 24 (11): 5297-5315. doi: 10.5194/hess-24-5297-2020.

Témez, J.R., 1977. Modelo matemático de transformación precipitación-aportación. ASINEL.

Trewin, B.C., 2007. Función de las normales climatológicas en un clima cambiante. Edited by $\mathrm{O}$. Baddour and $\mathrm{H}$. Kontongomde. Organización Meteorológica Mundial. Vol. 43. Ginebra.

Wang, Y., Zhang, N., Wang, D., Wu, J., 2020. Impacts of cascade reservoirs on Yangtze River water temperature: Assessment and ecological implications. Journal of Hydrology 590, 125240. doi:10.1016/j.jhydrol.2020.125240

Whitehead, P.G., Wilson, E.J., Butterfield, D., Seed, K., 1998. A semi-distributed integrated flow and nitrogen model for multiple source assessment in catchments (INCA): part II - application to large river basins in south Wales and eastern England. Science of the Total Environment 210: 559-583. 
Xu, L., Li, H., Liang, X., Yao, Y., Zhou, L., Cui, X., 2012. Water quality parameters response to temperature change in small shallow lakes. Physics and Chemistry of the Earth 47-48, 128-134. doi:10.1016/j.pce.2010.11.005.

Zlatanović, L., van der Hoek, J.P., Vreeburg, J.H.G., 2017. An experimental study on the influence of water stagnation and temperature change on water quality in a full-scale domestic drinking water system. Water Research 123, 761-772. doi:10.1016/j.watres.2017.07.019.

\section{MATERIAL SUPLEMENTARIO}

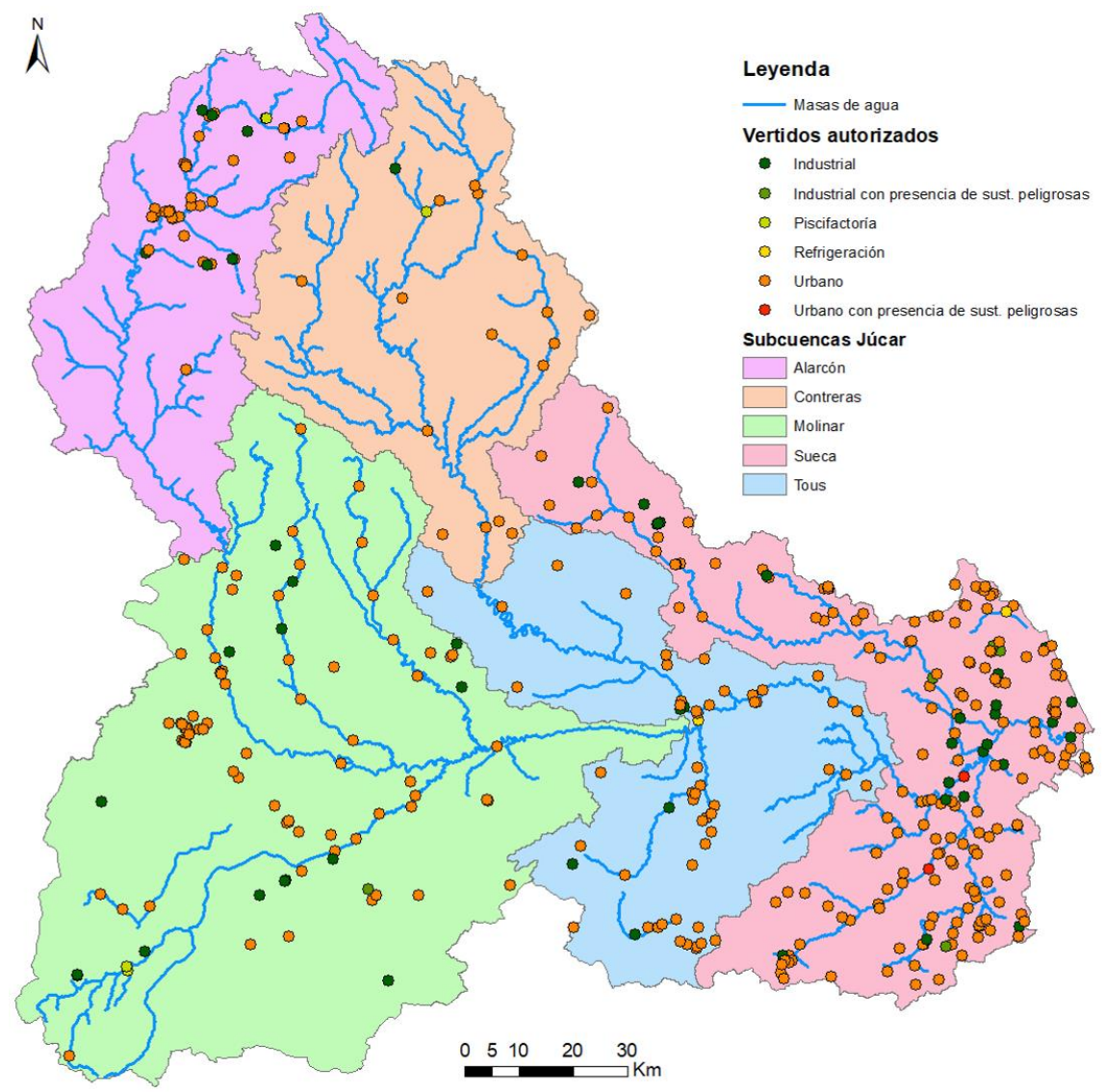

Figura 1 | Naturaleza de los vertidos autorizados en la cuenca del Júcar. Fuente: Censo de vertidos autorizados de la DHJ (CHJ, 2015). 


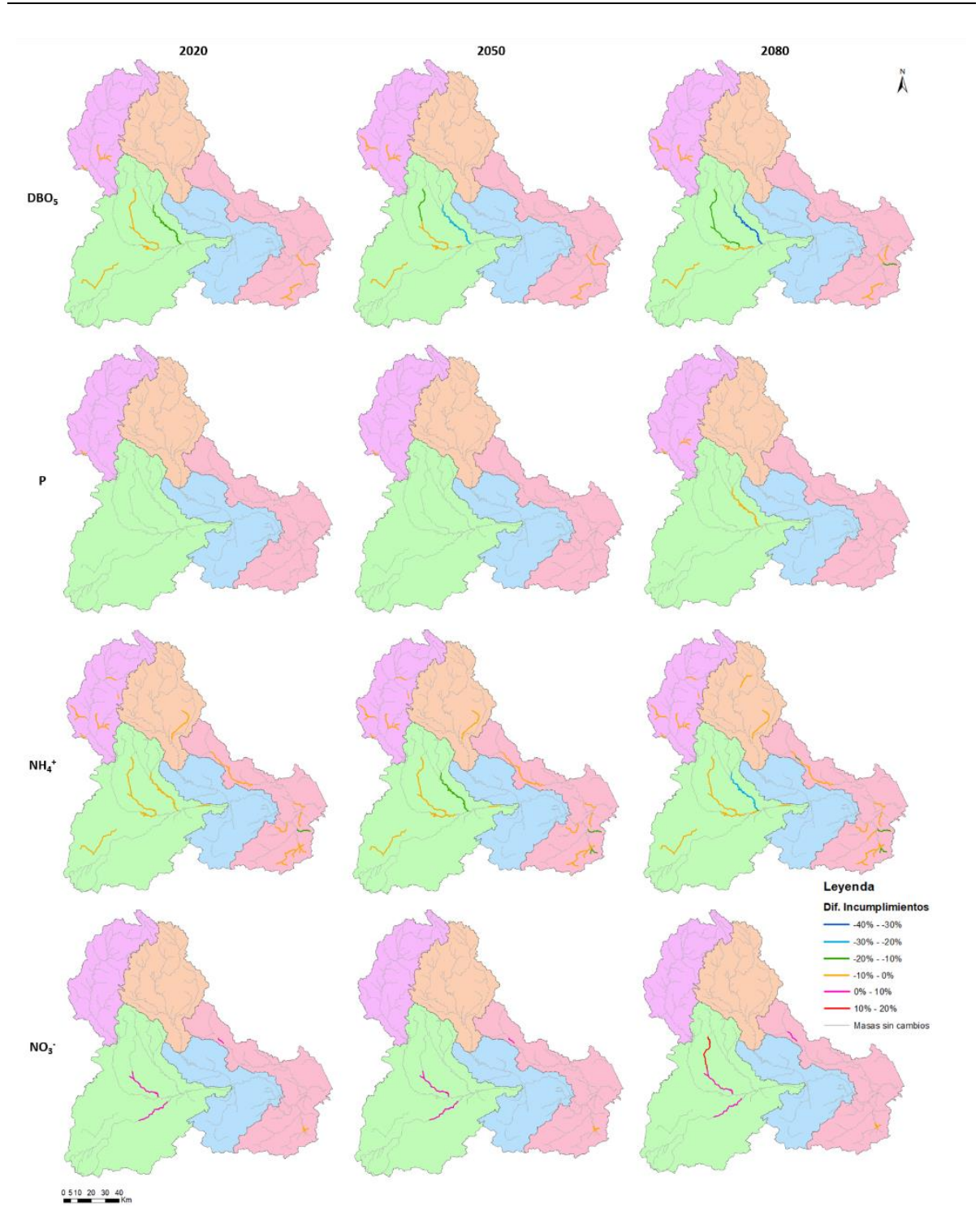

Figura 2 | Diferencia entre los incumplimientos de los horizontes futuros (2020, 2050 y 2080) y los del periodo de referencia en la simulación de la Ta futura para cada contaminante $\left(\mathrm{DBO}_{5}, \mathrm{P}, \mathrm{NH}_{4}{ }^{+}\right.$y $\left.\mathrm{NO}_{3}{ }^{-}\right)$. 


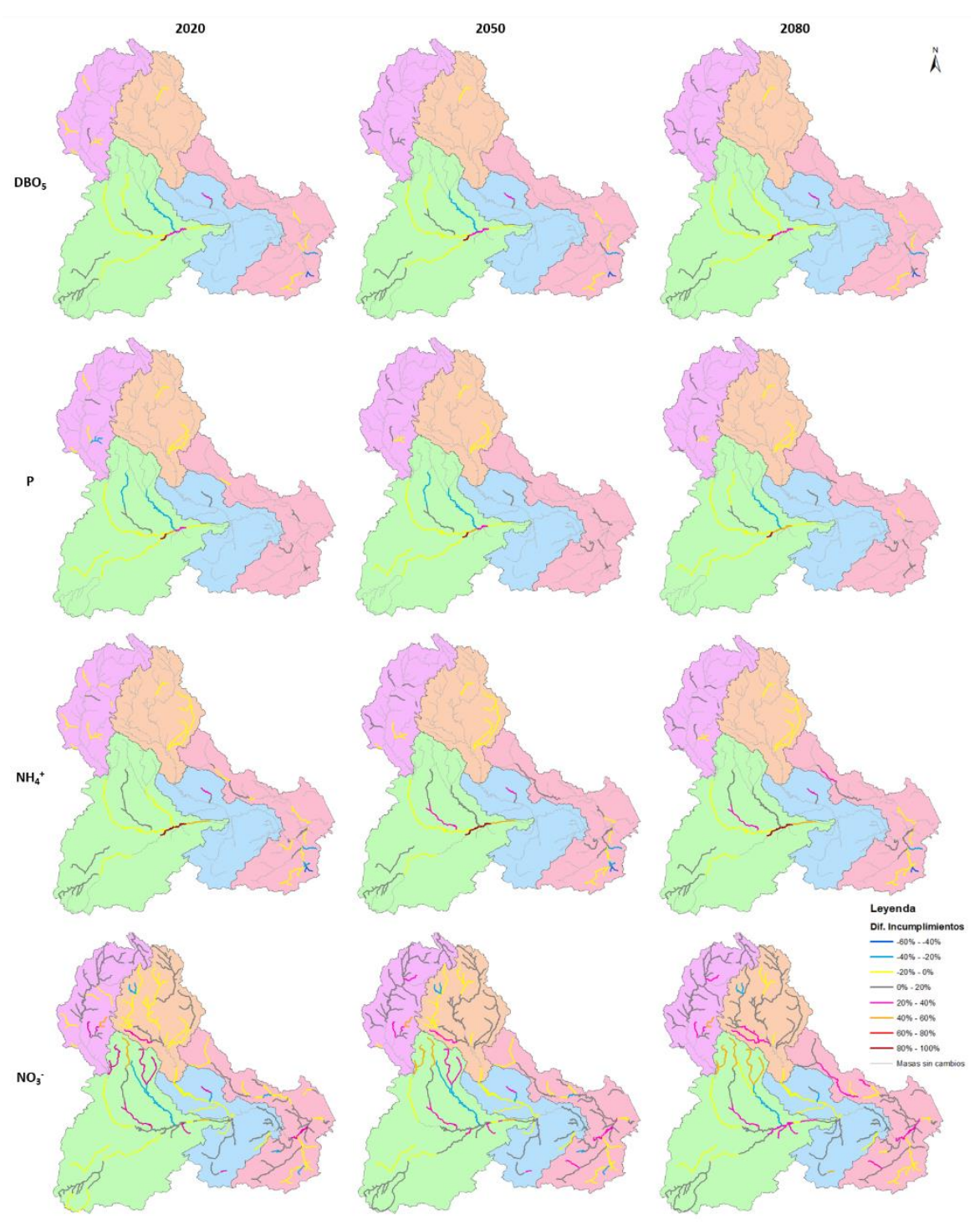

0.510 .2020 .000

Figura 3 | Diferencia entre los incumplimientos de los horizontes futuros (2020, 2050 y 2080) y los del periodo de referencia en la simulación de las aportaciones futuras para cada contaminante $\left(\mathrm{DBO}_{5}, \mathrm{P}, \mathrm{NH}_{4}{ }^{+}\right.$y $\left.\mathrm{NO}_{3}{ }^{-}\right)$. 


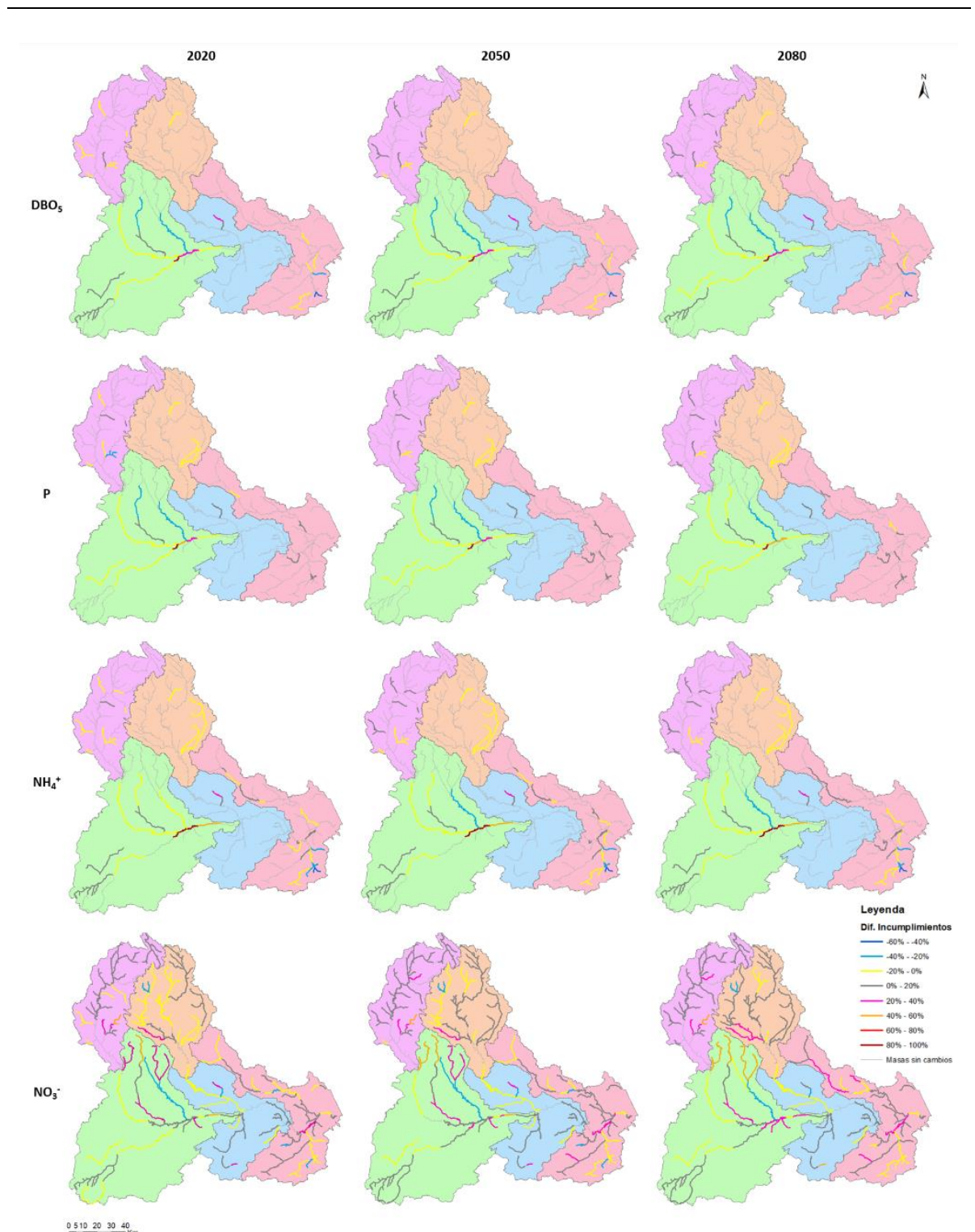

Figura 4 | Diferencia entre los incumplimientos de los horizontes futuros (2020, 2050 y 2080) y los del periodo de referencia en la simulación de la Ta y las aportaciones futuras para cada contaminante $\left(\mathrm{DBO}_{5}, \mathrm{P}, \mathrm{NH}_{4}{ }^{+}\right.$y $\left.\mathrm{NO}_{3}{ }^{-}\right)$. 


\subsection{Otras publicaciones y colaboraciones}

\subsubsection{Artículo en fase de publicación correspondiente a esta tesis}

Durante esta tesis también trabajamos en la integración de los pronósticos estacionales en la gestión hidrológica, completando así el estudio a largo plazo con otra metodología adaptada a este tipo de pronósticos de corto-medio plazo, relacionada con la gestión de la sequía a tiempo real.

Como se ha comentado anteriormente (sección 1.3.2.), la gestión de la sequía en la cuenca del Júcar se basa en la generación múltiple de series de aportaciones para llevar a cabo la evaluación del riesgo a corto-medio plazo y facilitar así la toma de decisiones. De hecho, esta metodología se encuentra operativa desde hace más de dos décadas en esta cuenca. Además, en estudios como el de Sánchez-Quispe et al., (2001), donde se estimó cual sería el periodo de anticipación ideal para la toma de decisiones, también se puso de manifiesto la importancia de que las series generadas respeten los estadísticos básicos de las aportaciones históricas y las características históricas de la sequía. Desde entonces hasta la actualidad, se han utilizado modelos estocásticos para llevar a a cabo esta generación de series en el proceso de evaluación del riesgo, concretamente un modelo multivariado autorregresivo de media móvil (ARMA) que basa su generación de series en caudales previos.

Por lo tanto, en este estudio se pretende mejorar la metodología ya existente mediante la propuesta de varios métodos de generación de series de aportaciones en los que es posible integrar los pronósticos estacionales, un producto de los servicios climáticos relativamente nuevo que podría aportar grandes ventajas en la gestión hidrológica mediante predicciones de riesgo más acertadas a corto-medio plazo.

A continuación, se presenta otro artículo en proceso de publicación que también forma parte de esta tesis, aunque no haya sido aceptado todavía. 


\subsubsection{Integración de pronósticos estacionales en la gestión en tiempo real de las sequías. El caso de la cuenca del Júcar}

En este artículo se analiza el posible valor añadido de los pronósticos estacionales en la gestión de la sequía en tiempo real. Para ello, se presentan varias metodologías de generación de series de aportaciones previo al análisis de riesgo de sequía, basadas en las propiedades de las aportaciones históricas, de los pronósticos estacionales, 0 en la combinación de ambas.

En la Fig. 13 se pueden observar los métodos alternativos de generación de series de aportaciones propuestos. En uno de ellos, esta generación se basa en las propiedades estadísticas de las aportaciones históricas, sin considerar en el proceso los pronósticos estacionales (metodología actualmente empleada en la cuenca del Júcar), por lo que se convierte en el método de referencia para evaluar los métodos que sí que consideran estos pronósticos. Se trata de un modelo estocástico ampliamente utilizado en este campo, un modelo auto-regresivo de media móvil (ARMA) (Box et al., 2016) que se utiliza en el caso de estudio con este propósito. Un modelo opuesto sería el hidrológico, ya que la generación de aportaciones está basada en datos de variables meteorológicas ( $P$ y $T$ o ETP), en este caso provenientes de pronósticos estacionales. También se propone utilizar la combinación de ambos datos empleando un modelo auto-regresivo de media móvil con variables exógenas (ARMAX) (Box et al., 2016), que funciona como el modelo ARMA (con aportaciones históricas) pero incluyendo variables externas en el proceso, en este caso procedente de los pronósticos estacionales ( $\mathrm{P}$ y/o $\mathrm{T}$ ). $\mathrm{Y}$, por último, el cuarto método propuesto es una red neural artificial (ANN por sus siglas en inglés) (Govindaraju y Rao, 2000; Rojas, 1996), con una estructura similar a las neuronas del cerebro basada en interconexiones ente las entradas y las salidas del modelo. En esta alternativa también se utiliza la combinación de aportaciones históricas y pronósticos estacionales de $\mathrm{P}$ y $\mathrm{T}$ para la generación de series. 
Seguidamente, las series generadas con cada alternativa se insertan en el modelo de evaluación de riesgo (por separado) para la obtención de un indicador de riesgo de sequía que informa sobre la evolución de almacenamiento probabilística del sistema a medio plazo, es decir, con unos meses de antelación. Además, este modelo también permite la obtención de resultados detallados para todas las demandas, caudales ecológicos, etc.

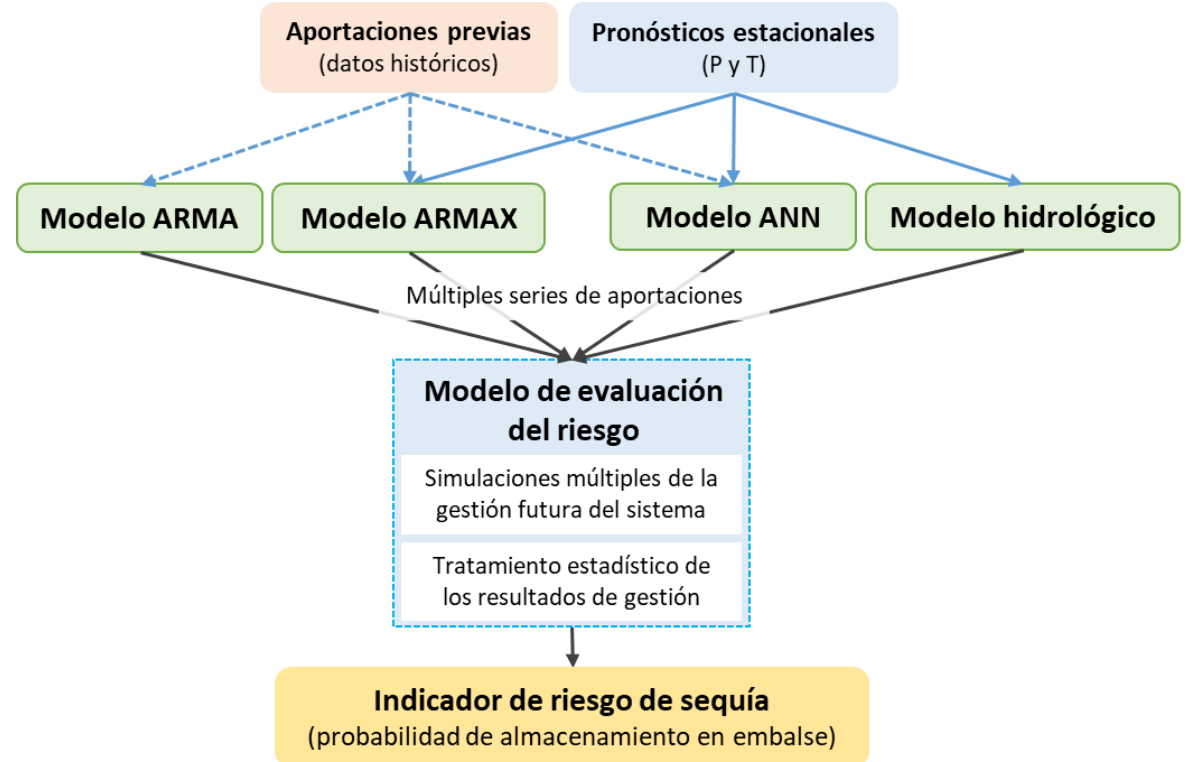

Fig. 13. Metodología para la inclusión de pronósticos estacionales en la gestión del riesgo de sequía en tiempo real por medio de varias técnicas de generación de caudales y un indicador probabilístico. Modificado de Suárez-Almiñana et al. (In press).

A partir de la comparación de estos resultados con los valores observados y el método de referencia (ARMA), es posible evaluar la capacidad predictiva de cada uno de ellos y saber si la integración de estos pronósticos en la predicción de estos eventos extremos es de utilidad para una mejor y más rápida respuesta frente a sus impactos en el proceso de toma de decisiones. 
Esta metodología también se adaptó a la cuenca del Júcar teniendo en cuenta los siguientes puntos:

1. Datos históricos y pronósticos estacionales: Los datos necesarios para este estudio son las series de aportaciones históricas y las de las variables de $\mathrm{P}$ y $\mathrm{T}$ procedentes de los pronósticos estacionales para cada subcuenca.

Las aportaciones en régimen natural del periodo 1980-2012 fueron aportadas por la $\mathrm{CHJ}$ y se utilizaron en la calibración de todos los modelos implicados en este proceso. Además, se utilizan como datos de entrada para el ARMA, ARMAX y las ANN.

Los pronósticos estacionales proceden de un ensamblado de 15 miembros para el periodo 1981-2015. Cada miembro contiene series diarias de P y de T para un horizonte de predicción de 7 meses a partir del primero de cada mes (Molteni et al., 2011). Estos pronósticos fueron corregidos por Madrigal Barrera, (2020) con distintos métodos y periodos de control para la $\mathrm{T}$ y la $\mathrm{P}$, dejando disponible un periodo de datos corregidos de 1991-2015. Estos datos se utilizaron en el ARMAX, las ANN y el modelo hidrológico.

2. Selección del periodo a analizar: Para analizar el comportamiento del sistema en función del método utilizado se seleccionaron dos años, uno clasificado como normal (2003/2004) y otro como seco (2005/2006). El año normal se corresponde con la situación previa a un evento de sequía (periodo 2005-2008), mientras que el año seco se encuentra inmerso en dicho evento extremo. Además, en cada año se inició la simulación en los meses de octubre y marzo, con el objetivo de predecir la temporada de riego y el estado final del sistema después de este período.

3. Métodos de generación de series: Los siguientes modelos se utilizaron para la generación múltiple de series de aportaciones: 
- ARMA: Un modelo auto-regresivo de primer orden $\operatorname{ARMA}(1,0)$ o $A R(1)$ que basa su generación en caudales previos, en este caso del mes anterior.

- ARMAX: Un ARMAX $(1,1,0,1)$ que se basa en caudales previos y la $P$ estacional como variable externa, en este caso del mes anterior para ambas opciones.

- ANN: Un modelo de ANN compuesto por 3 capas, una de entrada con 15 variables, una capa oculta de 3 nodos y una de salida con 5 variables. Las entradas se corresponden con las variables de $P, T$ de los pronósticos estacionales y las aportaciones del mes anterior $\left(Q_{t-1}\right)$ para cada subcuenca, mientras que las salidas son las aportaciones resultantes para las 5 subcuencas.

- Modelo hidrológico: El modelo precipitación-escorrentía HBV adecuadamente calibrado para esta cuenca (HBV-SEJ), en el que se introducen las P y ETP (aplicación del método Hargreaves a la T) procedentes de los pronósticos estacionales.

4. Modelo de evaluación del riesgo: Las series generadas en el punto anterior se insertan en este modelo (el mismo que en secciones anteriores) y se obtienen resultados a medio plazo (7 meses), como el indicador de riesgo de sequía, probabilidades de excedencia, déficits por demandas considerando el $10 \%$ de probabilidad de excedencia y volúmenes esperados.

Los principales resultados confirmaron la posibilidad de mejorar la capacidad predictiva de los métodos actuales gracias a los pronósticos estacionales, especialmente tras la aplicación de técnicas de posprocesamiento (corrección del sesgo) y el uso de modelos robustos y bien calibrados a escala de cuenca.

En general, los métodos propuestos ofrecen muy buenas expectativas para la gestión futura de la sequía en tiempo real, pero es necesario seguir investigando, tanto para mejorar los modelos propuestos en la metodología 
de generación de series, como para mejorar la pericia de los pronósticos estacionales, a fin de conseguir una mayor confianza por parte de los tomadores de decisiones en las predicciones de impactos de la sequía.

A continuación, se puede ver la versión de autor del siguiente artículo, con el permiso de todos los coautores:

Suárez-Almiñana, S., Andreu, J., Solera, A., Madrigal, J. (In press). Integrating seasonal forecasts into real-time drought management: Júcar River Basin case study. Journal of Hydrology. Indexada en el JRC y ubicada en el primer decil (Q1).

Integrating seasonal forecasts into real-time drought management: Júcar River Basin case study

${ }^{1 a}$ Sara Suárez-Almiñana, ${ }^{1 \mathrm{~b}}$ Joaquín Andreu, ${ }^{1 \mathrm{c}}$ Abel Solera, ${ }^{2 \mathrm{~d} J a i m e ~ M a d r i g a l ~}$

${ }^{1}$ Research Institute of Water and Environmental Engineering (IIAMA), Universitat Politècnica de València, 46022, Valencia, Spain

${ }^{2}$ Faculty of Civil Engineering, Universidad Michoacana de San Nicolás de Hidalgo, 58030, Morelia, Mexico

asasual@upv.es, ${ }^{b}$ ximoand@upv.es, casolera@upv.es, jaime.madrigal.b@gmail.com

Corresponding author: sasual@upv.es

\section{Abstract}

In future years, and due to climate change, the frequency and intensity of extreme events such as droughts will increase in some areas of the 
planet with water scarcity problems. This will affect the reliability and vulnerability of water resource systems (WRS). This study proposes several approaches for real-time drought management that will include meteorological seasonal forecasts in the process, with the aim of improving the predictive capacity of currently used methodologies and assisting in the decision-making process. These approaches consist of hydrological, ARMAX, and ANN models for inflow series generation included in a risk assessment analysis, producing a drought risk indicator of the probabilistic evolution of the WRS.

This study was conducted in the Júcar River Basin, a highly regulated Mediterranean WRS with previous experience in drought management based on stochastic models using previous historical inflows as input data. Here, the indicators from the proposed and current methods were compared to analyse the added value of seasonal forecasts in the field of drought management.

The main results confirmed the potential for improving the predictive capacity of current methods using seasonal forecasts, particularly after forecast post-processing techniques, and using well-calibrated models at the basin scale.

Key words: meteorological seasonal forecasts, ARMAX, ANN, hydrological model, real-time drought risk assessment, water resources systems.

\section{Introduction}

Recurrent drought episodes and their socio-economic and environmental impacts are a matter of concern worldwide, particularly in arid and semi-arid areas. Due to climate change, these events may be more recurrent and intense because of the expected decreasing precipitation rates and increasing temperatures in certain areas, such as the Mediterranean (Barranco et al., 2018; Hunink et al., 2019; IPCC, 2014). 
Drought is usually associated with a natural phenomenon of below average precipitation over a certain time period. This affects the other components of the hydrological cycle either rapidly, for example, river flows, or slowly, for example, piezometric levels (Ortega-Gómez et al., 2018). This may lead to insufficient quantities of water that are needed to meet the needs of ecosystems and human activities (Estrela and Vargas, 2012; Palop-Donat et al., 2020).

These issues require the implementation of effective management tools at the European level, as stated in the Water Framework Directive (EP, 2000). A good example of effective management tools is Drought Management Plans (DMP) (Estrela and Sancho, 2016; Estrela and Vargas, 2012; Ortega-Gómez et al., 2018) because they consider meteorological drought and its connection to hydrological, operational, and socioeconomic droughts to predict the impacts in advance (months or years). Operational drought is understood to be a situation of scarcity or deficit in water supply when the social and environmental demands of a water resources system (WRS) are not met (CHJ, 2018, 2015; Ortega-Gómez et al., 2018; Palop-Donat et al., 2020). DMPs are based on a set of scarcity indicators (Liu et al., 2017; Palop-Donat et al., 2020; Pedro-Monzonís et al., 2015) that inform water managers and final users about the state of the WRS in a certain area and period (Ortega-Gómez et al., 2018). They are usually related to a group of measures associated with each state of the system to prevent the impacts of drought (CHJ, 2018).

In the real time management of DMPs, stochastic methods have been extensively applied to complex systems with multipurpose reservoirs (Andreu et al., 2007; Andreu and Solera, 2006; Pianosi and Soncini-Sessa, 2009) to estimate future risk probabilities in the short-term to mediumterm, and take measures in advance. These methods are often based on the statistical properties of historical time series, which is a drawback for real applications because according to climate change studies, these properties are unlikely to be repeated in the future. Nonetheless, these methods are 
widely used because they are considered by decision-makers to be robust and reliable methods, despite the computational complexities and model simplifications of the WRS (Pianosi and Soncini-Sessa, 2009).

In recent years, seasonal meteorological forecasts have been considered suitable options for risk assessment in Europe because of improvements through the application of post-processing techniques and using hydrological models at the European scale to obtain hydrological forecasts (Arnal et al., 2018; Grillakis et al., 2017; Macian-Sorribes et al., 2020). However, these forecasts are more common outside Europe (Arnal et al., 2018) because they are derived from a wide range of global meteorological models, for example, the global coupled ocean-atmosphere general circulation model, and their predictability depends on large-scale climate patterns, for example, the EI Niño-Southern Oscillation (ENSO) and the North Atlantic Oscillation (NAO) (Arnal et al., 2018). These climate patterns may be unrelated to certain areas of Europe, and therefore, provide low skill for the ensemble and lead times.

In the Mediterranean area, immense efforts have been made to improve their skill for real applications (Grillakis et al., 2018; Groot et al., 2019; Hunink et al., 2019; Li et al., 2017; Macian-Sorribes et al., 2020; Madrigal Barrera, 2020). Considerable skill for the three first months was obtained after post-processing and the extraction of hydrological forecast in this area, but the skill varied with season and location (Arnal et al., 2018; Crochemore et al., 2020; Grillakis et al., 2018; Li et al., 2017; MacianSorribes et al., 2020; Wanders et al., 2019). Despite this progress, water managers are reluctant to use these models in the decision-making process. This may be due to factors such as, forecast biases, quality and uncertainty, post-processing requirements, miscommunication between providers and users, their economic situation, and their risk perception or risk tolerance (Arnal et al., 2016; Crochemore et al., 2016; Lavers et al., 2020; Wanders et al., 2019). 
The main objective of this study is to analyse the seasonal forecasts and determine whether they add value to future real-time drought management through several alternatives of inflow generation prior to the risk assessment. From this, a drought risk indicator that is easily understandable for all the stakeholders can be extracted for several months in advance.

This study was conducted in the Júcar Basin, which is a highly regulated basin with high hydrological variability and a typical Mediterranean climate, which leads to multi-annual recurrent drought events. In this basin, drought management experience is considerable. It is based on the implementation of measures for risk assessment from stochastic processes, without incorporating seasonal meteorological forecasts. The method presented here could provide a reference for estimating the predictive capacity and added value of the proposed alternatives, whereby, seasonal forecasts are integrated in different ways.

Section 2 provides details of the Case Study. The methodological alternatives and their adaptation to the case study can be found in Section 3. In Section 4, the indicators and predictive capacities results are presented. The results are discussed in Section 5, and the main conclusions are presented in Section 6 .

\section{Case study}

The Júcar River Basin (JRB) is a semi-arid area located in eastern Spain. It is influenced by the Mediterranean climate. The Júcar River is $512 \mathrm{~km}$ long and crosses the provinces of Cuenca, Albacete, and Valencia before reaching the Mediterranean Sea.

This is the most important WRS of the Júcar River Basin District (JRBD) because of its size $\left(22,187 \mathrm{~km}^{2}\right)$ and water resources generated $(1,605$ $\mathrm{Mm}^{3} /$ year) (CHJ, 2015). 
High hydrological variability is the main feature of this basin. It has an average precipitation ( $P$ ) of $475.2 \mathrm{~mm} /$ year, an average potential evapotranspiration (PET) of $926.6 \mathrm{~mm} /$ year, and an annual average temperature $(\mathrm{T})$ of $14.2{ }^{\circ} \mathrm{C}(\mathrm{CHJ}, 2015)$. This variability, in addition to high water demands ( $80 \%$ agriculture, $15 \%$ urban, and $5 \%$ others) has led to a highly regulated system in order to address water scarcity and recurrent multiyear droughts. These droughts occurred in the periods 1981-1986, 1992-1995, 2005-2008, and 2013-2018 and resulted in socio-economic and environmental impacts.

The water resources of the basin are stored in several reservoirs and in the aquifers of La Mancha Oriental in the middle part of the basin and La Plana de Valencia in the lower basin because of permeable materials that allow the infiltration of rainfall. The main reservoirs of this WRS are in the headwaters of the inland mountainous area. They are Alarcon $\left(1,112 \mathrm{Mm}^{3}\right)$ and Contreras $\left(444 \mathrm{Mm}^{3}\right.$ ) reservoirs, which operate on a multi-year scale (Suárez-Almiñana et al., 2020). The Tous reservoir $\left(240 \mathrm{Mm}^{3}\right.$ ) operates on an annual basis in the middle part of the basin in a high plain (Figure 1).

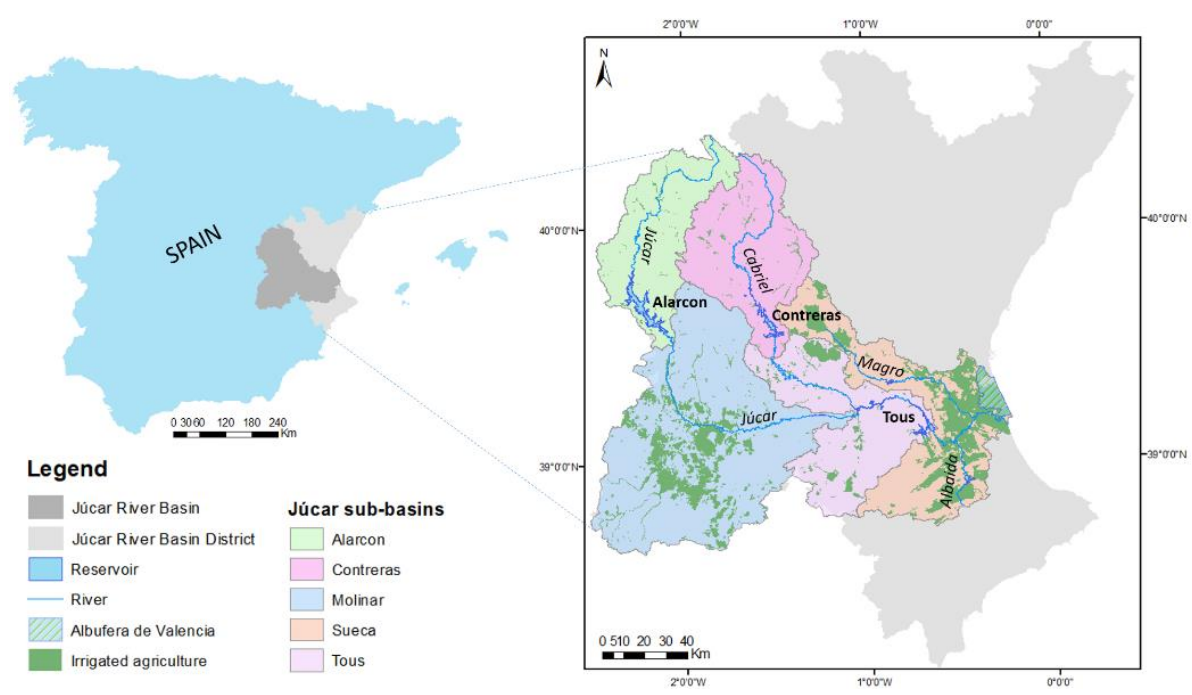

Figure 1. Location of the Júcar River Basin and its principal features. 
These sources of surface and groundwater resources are used conjointly to supply all users, particularly those of higher priorities such as urban areas and agriculture, which has the most consumptive demand. The main area of the irrigated crops is located in the middle basin and in the coastal plain, coinciding with the location of the aquifers, where the Albufera de Valencia, an important wetland $(211.2 \mathrm{~km} 2)$ is located. The wetland is composed of a lake surrounded by rice crops.

To deal with the complexities of this stressed system, which has a water demand and water resource ratio of approximately $90 \%$ (Suárez-Almiñana et al., 2020), the Júcar River Basin Authority (JRBA) has implemented a wide range of management strategies. These management strategies are considered in the Júcar River Basin District Management Plan (JRBDMP) (CHJ, 2015) and the DMP (CHJ, 2018).

The first DMP was approved in this basin in March 2007 and evolved from traditional emergency actions (Estrela and Sancho, 2016) in the middle of an intense drought event in 2005-2008. Based on the postdrought technical report of this drought event (CHJ, 2010), the assessment of the fulfilment of the DMP objectives aimed to minimise the environmental, economic, and social aspects of the drought situation. It was unique because many measures considered in the DMP were being applied and tested in the management of the drought that occurred simultaneously with its drafting and approval.

The real-time drought risk assessment process consisted of the generation of many inflow scenarios for the short-term and medium-term with a stochastic model connected to a risk assessment model, where the set of measures was tested and implemented before its application. In addition, the measures applied were defined and approved by the Permanent Commission of Drought during the entire period. This entity defined the development and degree of measures applied in each year through the approval of the different Action Plans according to the hydrological conditions and the evolution of the drought. The plans 
comprised four main lines of action that were quantified in 75 million $€$ at the end of this event. These actions were environmental protection measures, management and control measures, saving measures and alternative sources, and the generation of additional resources (CHJ, 2010).

Currently, the DMP of this basin (CHJ, 2018) is based on the Prolonged State Drought Indicator (PSDI) and the Scarcity State Indicator (SSI). Both are non-dimensional indicators that vary from 0 to 1 , but the PSDI uses precipitation data to highlight the drought situation, and the SSI integrates precipitation, piezometry, reservoir storage, and gauging station variables to improve decision-making and the implementation of restriction measures (Palop-Donat et al., 2020). These measures are related to several scarcity scenarios, namely, normality, pre-alert, alert, and emergency, depending on the SSI values (Pedro-Monzonís et al., 2015).

The broad drought management experience of this basin has brought positive results in recent years (Estrela and Sancho, 2016), but climate change has not yet been considered. Drought management must have a certain capacity to adapt to the specific conditions of future droughts $(\mathrm{CHJ}$, 2010), and therefore, the inclusion of seasonal forecasts in real-time drought management may be critical to improving the current methodologies.

\section{Material and methods}

In this section, a drought risk assessment process is presented to estimate whether the inclusion of seasonal forecasts in real-time drought management adds value. For this purpose, multiple inflow series needed by the risk assessment model were generated by using different approaches considering the previous historical inflows, seasonal forecasts, or a combination of both.

As a result, four alternatives for inflow generation were proposed (Figure 2). For one, the inflow series generation is based on the statistical 
properties of the historical inflows and does not consider the seasonal forecasts in the process. An autoregressive moving-average model (ARMA) (Box et al., 2016; Salas et al., 1980) is a stochastic model widely used in this field, and the current method used in this basin. The alternative case is the use of a hydrological model, in which inflow generation is based on $\mathrm{P}$ and $\mathrm{T}$ or PET data from seasonal forecasts, using only the historical inflows for its calibration (García-Romero et al., 2019). A combination of historical inflows and seasonal forecast data can then be used in the other stochastic model, namely, the autoregressive moving-average model with exogenous variables (ARMAX) (Box et al., 2016). This model works as the ARMA model (with historical inflows) but includes an extra variable in the process, in this case obtained from seasonal forecast data ( $P$ and/or $T)$. The fourth method is an Artificial Neural Network (ANN) (Govindaraju and Rao, 2000; Rojas, 1996), whereby, both sources of data can be used to generate the inflow series. These networks are based on interconnections between nodes, and have several layers, namely, input, hidden, and output, depending on the input and output variables.

All the generated series from the different approaches were separately inserted into the risk assessment model, and after the multiple simulation of system management and the statistical treatment of the management results, a drought risk indicator for the probability of storage in the system was obtained. This indicator showed the probable evolution of the water resources of the system in the medium term, that is, a few months in advance. In addition, other results can be obtained in this process, such as exceedance probabilities, expected storage volumes of the system, and deficits by demands considering a certain percentage of exceedance probability. 


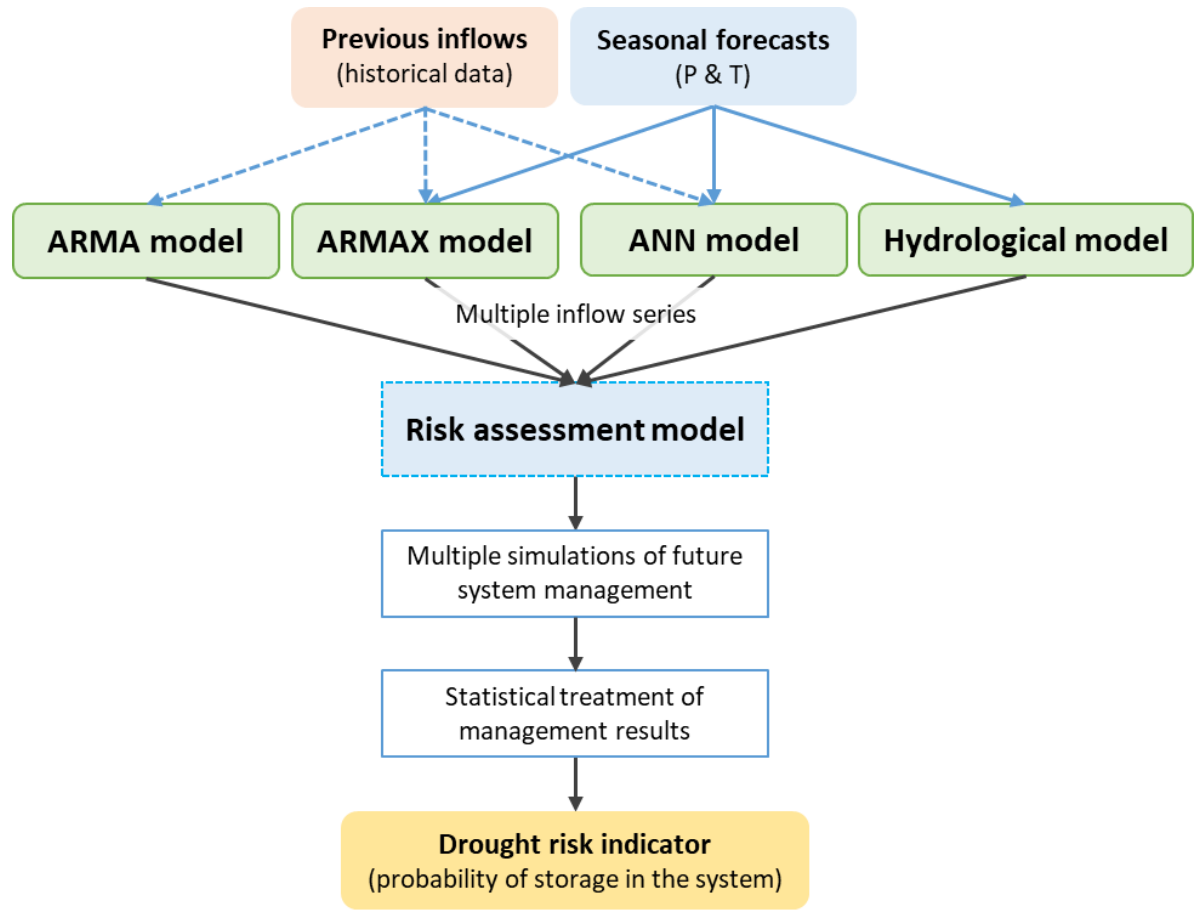

Figure 2. Methodology for drought risk assessment, differentiating between inflow generation models that incorporate previous historical data, seasonal forecasts, or a combination of both.

From the comparison of these results and the observed values, it is possible to evaluate the predictive capacity of each of them and observe the differences with the current methodology used in the JRB. In this way, the best option for addressing extreme events in the future can be selected, as well as knowing whether the integration of seasonal forecasts for predicting these extreme events is useful for obtaining a better and faster response to its impacts in the decision-making process. 


\subsection{Data collection and processing}

In this study, historical inflows and $\mathrm{P}$ and $\mathrm{T}$ time series from seasonal forecasts were required.

The historical natural inflows for each sub-basin at the monthly scale were provided by the $\mathrm{CHJ}$ (Figure 1) and were used to calibrate all approaches applied in the study for the period 1980-2012. The previous inflows required in the ARMA, ARMAX, and ANN models to generate the future series (Figure 2) were also obtained from these data.

The seasonal forecasts were provided by the European Centre for Medium-Range Weather Forecasts (ECMWF) and were obtained from the Seasonal Forecast System model (System4) (Molteni et al., 2011). This model is a dynamic prediction system that produces daily $\mathrm{P}$ and $\mathrm{T}$ series for a seven-month lead-time, generated from the first day of each month (Wetterhall and Di Giuseppe, 2017) and composed by 15 ensemble members. They are predictions of a historical period and are known as hindcasts or reforecasts. In this case, they were generated for the period 1981-2015 in a grid of 0.7o (Molteni et al., 2011). Two points from each sub-basin were taken and averaged to obtain representative $P$ and $T$ series per sub-basin (Madrigal et al., 2018).

These seasonal data were bias-corrected (Madrigal Barrera, 2020) based on the observed values of the Spain02_v5 dataset (Herrera et al., 2016; Kotlarski et al., 2017). This dataset contains daily time series of meteorological variables ( $\mathrm{P}$ and $\mathrm{T}$ ) for the period 1951-2015 in a grid of 0.10o, covering the Iberian Peninsula and the Balearic Islands. For this study, four points were taken and averaged from each sub-basin (Madrigal et al., 2018). These data were used for the bias correction and to calibrate the ARMAX, ANN, and hydrological models (1980-2012).

The bias correction was applied to $\mathrm{P}$ and $\mathrm{T}$ using different control periods of ten and three years, respectively, because of the nature of these 
forecasts (Madrigal Barrera, 2020). The quantile mapping technique (Gudmundsson et al., 2012; Teutschbein and Seibert, 2012) was applied to correct the $\mathrm{P}$ data, and the $\mathrm{T}$ data were corrected using the linear scaling method (Lenderink et al., 2007; Teutschbein and Seibert, 2012). After the bias correction, and based on the control periods, the corrected data were restricted to the time 1991-2015 for $\mathrm{P}$ and to the time 1984-2015 for T.

After the input data were collected and corrected they were normalised and standardised to $N(0,1)$ for building and calibrating the models to generate the inflow series. After the series was generated, this process was reversed to implement them in the risk analysis process.

\subsection{Approaches to generate multiple inflow series}

The inflow series was generated using different models that were built in different software, depending on the resources available for the purposes of this study. The software programs were in the $R$ environment for statistical computing (ver. 3.4.0) (R Core Team, 2020), the MATLAB numerical computing environment (ver. R2020a) (Higham and Higham, 2016), and the AQUATOOL Decision Support System Sell (DSSS) (Andreu et al., 2009, 1996). This is user-friendly and deals with water resource issues on a basin scale throughout its different modules. These modules for water quantity and quality can be accessed from the same interface, where all the features of the system can be integrated to simulate the management of the system for water allocation. The modules used in this study were EVALHID (García-Romero et al., 2019; Paredes-Arquiola et al., 2012) for the hydrological model, MASHWIN (Ochoa-Rivera, 2008, 2002) for the stochastic model (ARMA), and SIMRISK (Haro-Monteagudo, 2014; HaroMonteagudo et al., 2017; Sánchez-Quispe et al., 2001) for the risk assessment model. The R program was used for the ANN model and MATLAB was used for the ARMAX model. 


\subsubsection{Stochastic models: ARMA and ARMAX}

ARMA and ARMAX are similar models, but ARMAX integrates an exogenous variable in the process. Both are multivariate models, meaning that they work for the five sub-basins at the same time, conserving spatial and temporal dependence. They are integrated with the process as follows:

A multivariate ARMA model is the current method used in the JRB for real-time drought management. It generates a synthetic series from historical inflow data on a monthly basis using the following equation (Box et al., 2016; Salas et al., 1980):

$$
Z_{t}=\sum_{i=1}^{p} \varphi_{i} Z_{t-i}+\varepsilon_{t}-\sum_{i=1}^{q} \theta_{i} \varepsilon_{t-i}
$$

where $Z_{t}$ and $Z_{t-i}$ are the inflows vectors for the five sub-basins at time $t$, the random variables $\varepsilon_{\mathrm{t}}$ and $\varepsilon_{\mathrm{t}-\mathrm{i}}$ are white noise error terms vectors, $\mathrm{p}$ and $\mathrm{q}$ are the orders of the model in vector form, and $\varphi_{i}$ and $\theta_{i}$ are the matrix parameters of the model.

With this type of modelling, the generated series reproduces the basic statistics of the historical inflow series based on the correlation between the five sub-basins and their temporal autocorrelations. The preservation of the historical characteristics of the drought is not explicit in the model formulation, but it is always checked at the beginning of the process to ensure that these features are reproduced.

Here, a multivariate autoregressive model of first-order AR(1) or ARMA $(1,0)$ was built because its performance in other works was considered satisfactory to represent the inflow characteristics of the JRB (HaroMonteagudo et al., 2017; Sánchez-Quispe et al., 2001; Suárez-Almiñana et al., 2020, 2017). It was implemented and calibrated directly in the AQUATOOL DSSS interface connected to the MASHWIN module specifications that generate the flow series needed from the historical 
statistics (period 1980-2012), so that its generation was automatic and simple through the DSS after all the data from the Júcar WRS were integrated.

The multivariate ARMAX model was built in the MATLAB computing environment because of the extensive information and examples available for its development. The formulation of this model is presented in Equation 2, which was adapted from Equation 1 based on the formulation of Box et al. (2016). The resulting expanded equation used is:

$$
Z_{t}=\sum_{i=1}^{p} \varphi_{i} Z_{t-i}+\sum_{i=1}^{r} \omega_{i} Y_{t-k i}+\varepsilon_{t}-\sum_{i=0}^{q} \theta_{i} \varepsilon_{t-i}
$$

where $Z_{t}$ and $Z_{t-i}$ are the inflows vectors for the five sub-basins at time $t$, $Y_{t}$ is the vector of seasonal $P$ (exogenous variable) for the five sub-basins, $\varepsilon_{t}$ and $\varepsilon_{\mathrm{t}-\mathrm{i}}$ are vectors of random white noise variables, $\varphi_{\mathrm{i}}, \omega_{\mathrm{i}}$ and $\theta_{\mathrm{i}}$ are the matrix parameters of the model, and $p, r, q$ and $k$ are the orders of the model in vector form. $p$ represents the number of autoregressive terms that should be considered for the result series, that is, the dependence on past values, $r$ represents the number of exogenous terms that should be entered as information, $\mathrm{q}$ is the number of moving average terms, and $\mathrm{k}$ is the time delay between inflows and $P$ variables.

The calibration was performed using an iterative process to find the optimal combination of model orders, resulting in 48 models with orders between 0 and 4 . There were different range values depending on the orders. The selection of the best-fitted model was based on the combination of the minimum values from various statistics that measured how well the response of the model fitted the estimation data and the model quality. These were, the final prediction error (FPE), the mean squared error (MSE), the raw Akaike information criteria (AIC), and the Bayesian information criteria (BIC) (Ljung, 1999; Moriasi et al., 2007). The values of each of these statistics were weighted in deciles from 1 to 10 and 
then summed to obtain values between 4 (minimum value) and 40 (maximum value) for the 48 models.

Table 1 shows the values of the fitting statistics and weighted indicators of some of the resulting models, where an $\operatorname{ARMAX}(1,1,0,1)$ was the best option for this case (lower weighted indicator).

Table 1. Calibration statistics and weighted indicators for several ARMAX models with different orders combinations.

\begin{tabular}{c|c|c|c|c|c} 
ARMAX & FPE & BIC & AIC & MSE & Weighted indicator \\
\hline $\mathbf{( 1 , 1 , 0 , 1 )}$ & 0.03 & 2785.67 & 2588.14 & 3.74 & $\mathbf{5}$ \\
\hline $\mathbf{( 1 , 2 , 0 , 1 )}$ & 0.04 & 2975.37 & 2679.07 & 3.73 & 7 \\
\hline $\mathbf{( 1 , 2 , 0 , 2 )}$ & 0.04 & 2958.16 & 2661.86 & 4.34 & 12 \\
\hline $\mathbf{( 1 , 1 , 1 , 1 )}$ & 0.13 & 3337.53 & 3120.25 & 3.78 & 14 \\
\hline $\mathbf{( 1 , 2 , 1 , 1 )}$ & 0.15 & 3497.47 & 3181.42 & 3.73 & 16
\end{tabular}

The ARMAX $(1,1,0,1)$ is a model based on a first-order autoregressive term (inflow from the previous month), the information of one exogenous term (the corresponding value of $\mathrm{P}$ ), and 0 for the moving average term. The time delay between the inflows and $\mathrm{P}$ was considered as 1 for the last term.

\subsubsection{Artificial Neural Network}

These types of models are based on weighted connections between the nodes of the input, hidden, and output layers. In this case, a simple multilayer perceptron feed-forward ANN with a single hidden layer was used. In this type of ANN, the information moves in one forward direction, from the input to the output layers.

These networks must be trained and tested before being used as calibration and validation processes. For this process, the historical series 
should be divided into two parts, namely, $80 \%$ for training and $20 \%$ for testing (Arlot and Celisse, 2010). Therefore, the inflow historical series (1980-2012) was divided into training and testing, but taking into account two combinations of this division for cross-validation, a complete process that considers various training and testing periods from the same series to improve the training of the network (Arlot and Celisse, 2010; Ramezan et al., 2019). Therefore, $20 \%$ of the historical series was taken from the beginning of the historical period (1980-1989 testing, 1990-2012 training) for the first division, and for the second division this $20 \%$ was taken from the end of the series (1980-2002 training, 2003-2012 testing) in order to ensure that the time correlation was not affected.

With the training and testing datasets per sub-basin ready, an iterative process within the "nnet" package of $R$ (Venables and Ripley, 2002) was developed, taking into account the possible input nodes (depending on the input variables), the number of nodes in the hidden (1 to 10), and the output layers (five, one per sub-basin). This process was based on the minimum results of the root mean square error (RMSE) (Ljung, 1999) after the network convergence for all possible combinations of input variables and hidden nodes.

Table 2 presents the lower values of the RMSE from the combination of the input variables and hidden nodes used in this process, which ended when the RMSE value increased after the inclusion of other variables.

Table 2. Variables, nodes and lower RMSE $\left(\mathrm{Mm}^{3}\right)$ obtained in the training process of the ANN.

\begin{tabular}{c|c|c} 
Variables for the 5 sub-basins & Hidden nodes & RMSE \\
\hline P & 2 & 0.910 \\
\hline P \& T & 4 & 0.860 \\
\hline P, T \& Q Q 1 1 & 3 & 0.677 \\
\hline P, T, Q $\mathbf{T}$ 1 \& Q Q 1 T & 3 & 0.687
\end{tabular}

In this case, the lowest RMSE was obtained with three nodes in the hidden layer for the input variables of $P, T$, and the inflows from the 
previous month (Qt-1) for the five sub-basins. Although three hidden nodes for 15 inputs (three variables per sub-basin) and five output nodes (one inflow series per sub-basin) may seem a low number, these input variables were highly correlated, and a higher number of nodes in this case may have led to overtraining the network.

Figure 3 shows the structure of the $\operatorname{ANN}(15,3,5)$ used in this study. Black and grey lines indicate positive and negative weights, respectively, and the line thickness is related to the influence on that output.

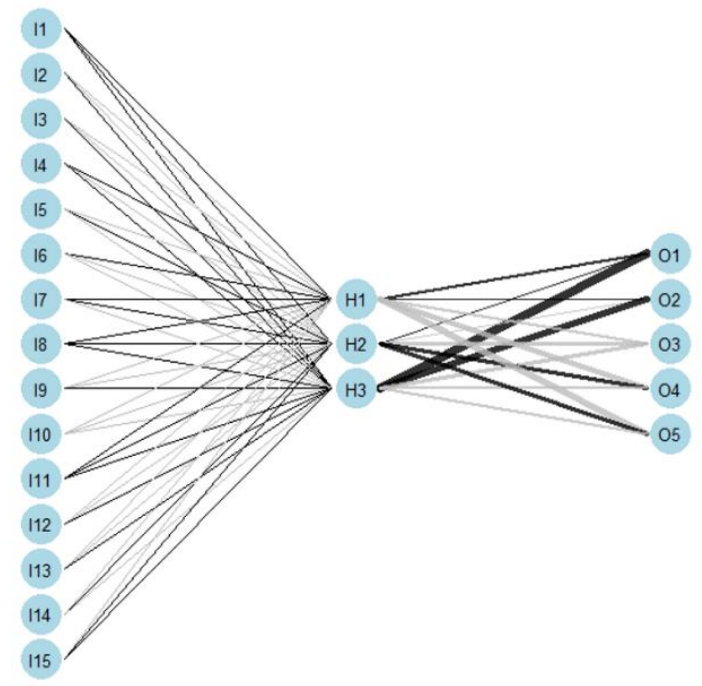

Figure 3. Artificial Neural Network model structure for inflows generation from seasonal forecasts and previous inflows.

\subsubsection{Hydrological model}

The rainfall-runoff HBV model (Bergström, 1995) was selected to extract the inflow series from seasonal forecasts (corrected $\mathrm{P}$ and $\mathrm{T}$ time series). It is a semi-distributed model that works on a sub-basin scale in complex basins, such as the JRB. A good daily-scale performance was demonstrated (Hernández Bedolla et al., 2019; Suárez-Almiñana et al., 2020) after an exhaustive calibration was conducted with a combination of two 
optimisation algorithms (García-Romero et al., 2019). The inputs for this model were $\mathrm{P}$ and PET time series, and so the Hargreaves method (Hargreaves and Samani, 1985) was applied to convert the corrected T into PET because of its simplicity and accuracy in this area (Espadafor et al., 2011; Hernández Bedolla et al., 2019; Milly and Dunne, 2017).

To use this model with all the ensemble members of the seasonal forecasts, a multiple simulation script was developed in $R$, which automatically changed the initial conditions of the model depending on the starting date of each simulation for the entire ensemble (Madrigal Barrera, 2020). The initial conditions were derived from an initial simulation of the management model with historical inflows, obtaining the values of the parameters of this model for each starting date. In this way, the historical conditions were preserved.

This model can be found in the EVALHID module of AQUATOOL DSSS, and therefore, the next step was the integration of the generated series into the risk assessment model (SIMRISK module), hereafter referred to as EVALRISK.

\subsection{Risk assessment model}

This model was integrated with the SIMRISK module of AQUATOOL DSSS. The risk assessment model integrates the inflow series generated for multiple simulations of the system management based on the Monte Carlo method. These management results were then statistically treated in order to extract some probabilistic indicators regarding, for example, the evolution of the water resources of the WRS, deficits, and reliabilities. These simulations can be performed in the short, medium, or long term, depending on the input data and the purposes of the study.

This model is currently used to predict the probable state of the system in the near future by the JRBA in real-time drought management. Furthermore, it allows an iterative process of testing measures through 
different scenarios in order to help decision-makers choose the most effective for reducing the future impacts of these events (HaroMonteagudo, 2014). The implementation of measures is beyond the scope of this study.

In this study, the model was used at the medium term due to the use of seasonal forecasts (seven months lead time) because the drought risk assessment at the seasonal scale is of interest. Therefore, the ensemble inflows generated in the previous alternatives (ARMA, ARMAX, ANN, and HBV models) were separately inserted into this model. The management of the system was then simulated for each inflow series, and a statistical treatment of the management results was performed to extract the drought risk indicator. This probabilistic indicator reported on the probabilistic evolution of the water storage of the system for seven months in advance. In addition, the total storage capacity of the system $(1,796$ $\mathrm{Mm}^{3}$ ) was considered as the sum of the capacities of the main reservoirs (Alarcón, Contreras and Tous) and was divided into 10 equal intervals to show the probability of being found in each of them.

\subsection{Selection of testing periods}

Two hydrological years from the remaining period after bias correction (1991-2015) were selected to illustrate and test this methodology. The selection was based on the hydrological cycles of wet/dry periods, which were related to water resource storage and the scarcity indexes of the WRS (CHJ, 2018).

As a result of the very intense drought episode that occurred during 2005-2008, the hydrological years 2003/2004 and 2005/2006 were chosen and classified as normal and dry years, respectively. The normal year is a period preceding the drought event and the dry year is involved in it, at the beginning. In addition, two initiation months per year were chosen for the simulation. The first starting date corresponded to October, meaning, from the beginning of the hydrological year to the start of the future irrigation 
season in April. March was the second initiation month, which corresponded to a period of seven months, which included the entire irrigation season until the end of the hydrological year in September. These months were related to a focus on irrigation campaigns because the agricultural sector is the major consumptive demand in this WRS (80\%) and is also the sector most affected by supply restrictions during droughts $(\mathrm{CHJ}$, 2018, 2015, 2010). The predictions for the preceding months of the irrigation season are the most decisive in decision-making because that is when water-saving decisions can be made for irrigation campaigns.

The methodology was tested using the data from two years classified as normal (2003/2004) and dry (2005/2006) periods and the simulation was initiated in October and March of both years to make predictions regarding the irrigation season and the final state of the WRS after this period. The aim of these simulations was to analyse the behaviour of the system under these different scenarios, depending on the input data used for the risk assessment.

\section{Results}

In this section, the results of the drought risk indicator are analysed. They result from the application of all the series generation methods in the two simulations (October and March) of the normal (2003/2004) and dry (2005/2006) years. Agricultural deficits with a 10\% exceedance probability, that is, the maximum deficits that could be reached in each scenario, are also analysed.

The combination of these results offers general and specific aspects of the state of the system under the different scenarios. The general view of the system can be analysed using the risk indicator because it represents the probabilistic evolution of the total volume of the WRS. The deficits are focused on the most demanding sector in the JRB, from the perspective of the agricultural sector. 
In addition, the predictive capacity of the approaches is evaluated by comparing the exceedance probabilities and the expected volumes in the system with the observed values. In this way, the added value of the seasonal forecasts can be assessed, and one method can be selected to integrate with real-time drought management based on its performance under different scenarios.

\subsection{Drought risk indicator and agricultural deficits}

The drought risk indicators from the risk assessment performed with the inflow series from the different approaches are depicted in Figures 4 and 5 . Figure 4 shows the indicator for the normal year simulated in October and March, and Figure 5 shows the same, but for the dry year.

The indicator resulting from the $A R(1)$ series generation is firstly discussed because this is the approach currently used for risk assessment in the JRB. Therefore, it serves as a reference point because it does not integrate seasonal forecasts with inflow generation.

In the October simulation of the normal year (Figure 4), there are high probabilities (80\%-100\%) of finding the system between $359-539 \mathrm{Mm}^{3}$ at the beginning of the hydrological year until the start of the irrigation season, when these probabilities decrease to $40 \%$. However, the simulation starting in March of the same year shows a more optimistic scenario for the first three months, where the probabilities of finding the system between 539-718 $\mathrm{Mm}^{3}$ are almost $100 \%$. Afterwards, high probabilities (80\%) of being under this volume interval $\left(180-539 \mathrm{Mm}^{3}\right)$ are found from summer to the end of the hydrological year in September. 

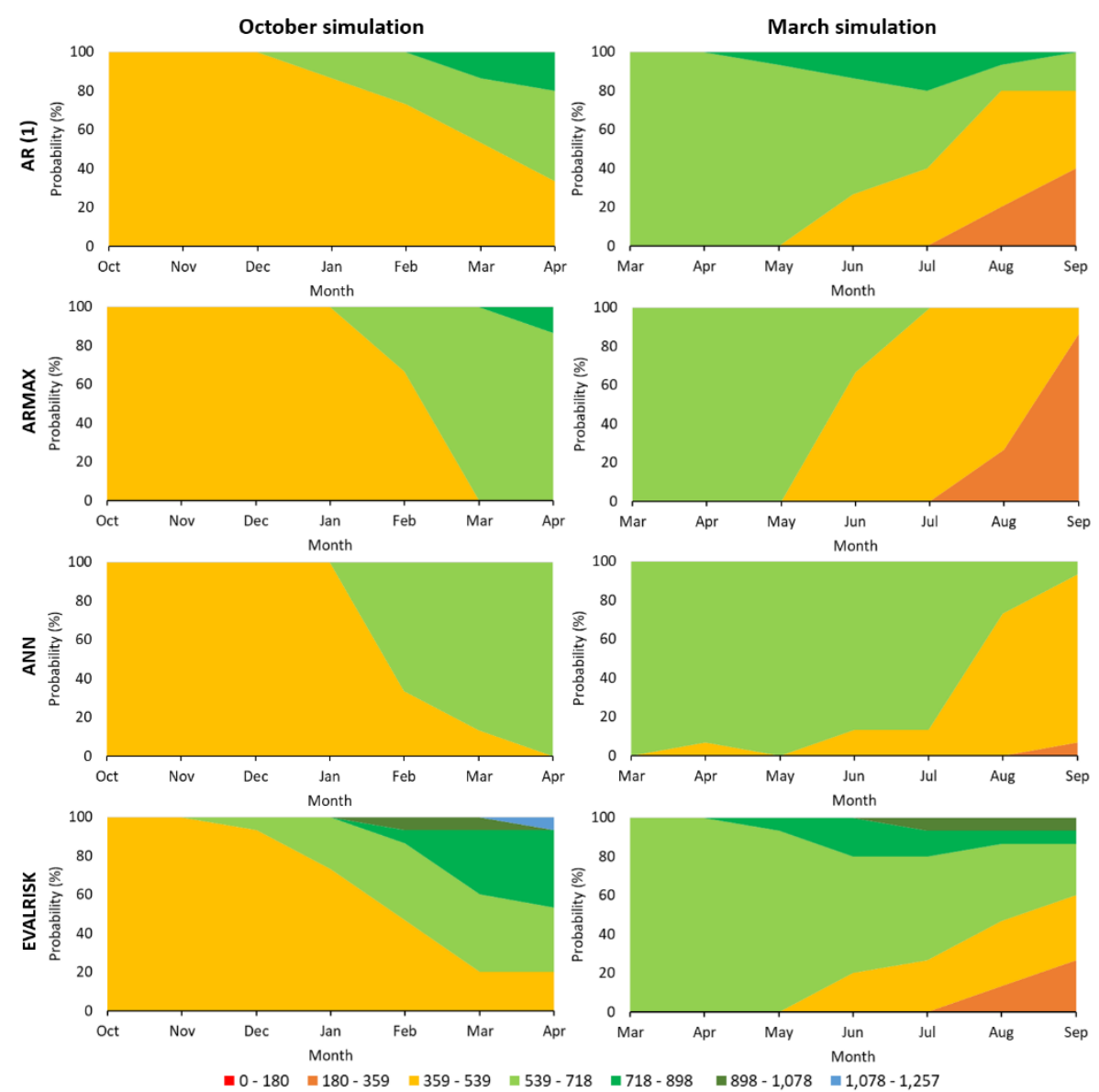

Figure 4. . Drought risk indicator for the normal year (2003/2004) considering October and March simulations from AR(1), ARMAX, ANN and EVALRISK approaches, where the probabilistic evolution of the total storage of the system $\left(1,796 \mathrm{Mm}^{3}\right)$ is considered through volume intervals (colours).

The indicator results from the ARMAX model (Figure 4) resemble the previous results, but this time the prediction for March and April coincides in both simulations. In addition, the increases or decreases in volume probabilities from month to month are more pronounced (slope) and the final state of the system in September is more likely (80\%) to be within 180-359 $\mathrm{Mm}^{3}$, therefore, presenting the worst scenario in this simulation. 
For the ANN model (Figure 4), the indicator shows lower variability. In the previous approaches, the probabilities were found in four different volume intervals and in this case, the prediction considers only two of them, except for September. In general, the system is most likely to be 359-539 $\mathrm{Mm}^{3}$ from October to January and 539-718 $\mathrm{Mm}^{3}$ from February to April. In contrast, the system is most likely to be $539-718 \mathrm{Mm}^{3}$ from March to July and 359-539 $\mathrm{Mm}^{3}$ for the last months of the year in the March simulation.

The indicators from the EVALRISK process (Figure 4) are more like those from the $A R(1)$ model because of the softer slope of changing probabilities and the more highly variable results. In this case, more than four volume intervals are considered, which are mostly found at the end of both simulations when the system is recovering during the irrigation season from March to April, and at the end of the hydrological year in September. The probability of being in the third volume interval (359-539 $\mathrm{Mm}^{3}$ ) gradually decreases from $100 \%$ in October to $20 \%$ in April, when it is more likely to find the system between 539-898 $\mathrm{Mm}^{3}$. In the March simulation, the same occurs with the probabilities being in the fourth volume interval (539-718 $\mathrm{Mm}^{3}$ ), which decreases from $100 \%$ to $20 \%$ in September. At the end of the year, there is an equal chance (50\%) of finding the system below or above $539 \mathrm{Mm}^{3}$.

Conversely, in the dry year indicators from the $A R(1)$ process (Figure 5), the probabilities of finding the system at $180-359 \mathrm{Mm}^{3}$ are generally high $(>60 \%)$ in both simulations. From June to September, the probability of having fewer water resources in the system $\left(0-180 \mathrm{Mm}^{3}\right)$ increases to $50 \%$.

In the ARMAX scenario (Figure 5), the results differ to a larger extent to those of the $A R(1)$ indicator and are more significant in this case. From October to February, a complicated situation is foreseen because the probability of being under the minimum $\left(0-180 \mathrm{Mm}^{3}\right)$ is $100 \%$ in November and December, although from January it is recovering and from February to April it is likely to be between 180-359 $\mathrm{Mm}^{3}$. Although this is a better 
scenario than the previous, it is of concern. In the indicator for the same year generated from March, the situation is consistent until June $(100 \%$ probability of being $180-359 \mathrm{Mm}^{3}$ ), when the system is at minimum capacity $\left(0-180 \mathrm{Mm}^{3}\right)$ with $100 \%$ probabilities from June to September, coinciding with the irrigation and summer seasons.
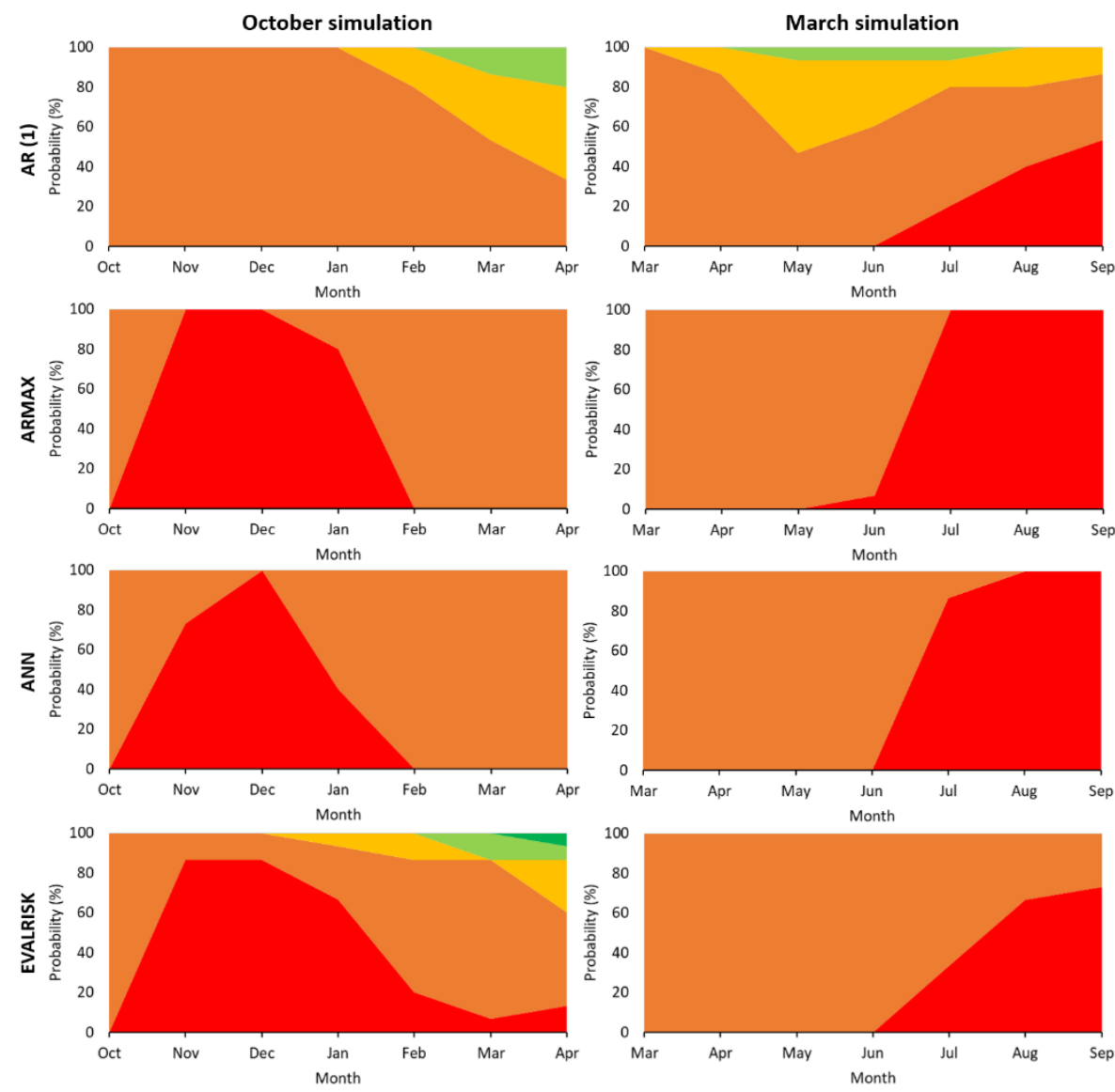

=0 - $180=180-359=359-539=539-718=718-898=898-1,078=1,078-1,257$

Figure 5. Drought risk indicator for the dry year (2005/2006) considering October and March simulations from AR(1), ARMAX, ANN and EVALRISK approaches, where the probabilistic evolution of the total storage of the system $\left(1,796 \mathrm{Mm}^{3}\right)$ is considered through volume intervals (colours). 
The ANN indicators (Figure 5) closely resemble the ARMAX, whereby, the same complicated situation is foreseen from October to February and from June to September, with $100 \%$ probabilities in the $0-180 \mathrm{Mm}^{3}$ range, but with lower probabilities in the first period.

In the EVALRISK process indicators (Figure 5), the probabilities of being below $180 \mathrm{Mm}^{3}$ are very high (70\%-85\%) from November to January. However, other higher intervals are considered with lower probabilities (<30\%) from February to April but are more likely (50\%-70\%) to be $180-359$ $\mathrm{Mm}^{3}$ in these months. The variability in the October simulation is in contrast to the probability results from the March simulation, where only two intervals are considered, leaving a concerning situation at the end of the hydrological year, with a $75 \%$ probability of being below $180 \mathrm{Mm}^{3}$ in September.

After the indicators are analysed, the deficits of the agricultural demands from the beginning of the irrigation season (March simulation), differentiating between both years, normal and dry, are investigated.

Table 3. Cumulative deficit (\%) in the agricultural demand with a $10 \%$ exceedance probability per sample year and approach for the March simulation.

\begin{tabular}{c|c|c|c|c|c|c|c|c} 
& \multicolumn{4}{|c|}{ Normal year 2003/2004 } & \multicolumn{4}{c}{ Dry year 2005/2006 } \\
\hline Month & AR(1) & ARMAX & ANN & EVALRISK & AR(1) & ARMAX & ANN & EVALRISK \\
\hline Mar & $0.1 \%$ & $0.1 \%$ & $0.1 \%$ & $0.1 \%$ & $0.1 \%$ & $0.3 \%$ & $0.3 \%$ & $0.3 \%$ \\
\hline Apr & $0.2 \%$ & $0.2 \%$ & $0.2 \%$ & $0.2 \%$ & $0.4 \%$ & $0.6 \%$ & $0.6 \%$ & $0.6 \%$ \\
\hline May & $0.5 \%$ & $0.5 \%$ & $0.5 \%$ & $0.5 \%$ & $1.1 \%$ & $2.3 \%$ & $2.2 \%$ & $2.0 \%$ \\
\hline Jun & $0.9 \%$ & $0.9 \%$ & $0.9 \%$ & $0.9 \%$ & $1.9 \%$ & $3.7 \%$ & $3.4 \%$ & $3.0 \%$ \\
\hline Jul & $1.5 \%$ & $1.4 \%$ & $1.3 \%$ & $1.3 \%$ & $4.4 \%$ & $6.8 \%$ & $7.7 \%$ & $5.5 \%$ \\
\hline Aug & $2.0 \%$ & $1.9 \%$ & $1.6 \%$ & $1.8 \%$ & $11.1 \%$ & $14.3 \%$ & $15.0 \%$ & $12.6 \%$ \\
\hline Sep & $2.2 \%$ & $2.1 \%$ & $1.8 \%$ & $1.9 \%$ & $14.5 \%$ & $15.3 \%$ & $16.0 \%$ & $15.9 \%$
\end{tabular}

Table 3 shows the cumulative deficits of the agricultural sector with a $10 \%$ exceedance probability. Although $10 \%$ appears to be a low probability, in this way, the maximum values that can be reached in normal and dry 
years are more differentiated, taking into account the worst situation that may occur in both cases.

The cumulative deficits from the normal year are very low compared to those from the dry year, particularly from the summer period to the end of the year (June-September), as could be expected from the indicator results (Figures 4 and 5).

When the $A R(1)$ approach is applied, the difference between the accumulated deficits at the end of the irrigation season between the normal and dry years is $12.3 \%$ of the agricultural demand. This is an important difference to be considered because this deficit may lead to substantial economic losses, especially if the water scarcity scenario extends for several years.

The deficits from the ARMAX approach resemble those of the AR(1) process in the normal year, however, as could be expected from the indicators (Figure 4 and 5), the deficits in the dry year are higher. In this case, the differences between the cumulative deficits at the end of the irrigation season in both years are $13.2 \%$, which is slightly more than in the previous case, but equally concerning.

In the case of the ANN and EVALRISK alternatives, the cumulative deficits in the normal and dry years resemble the previous options, but are slightly lower in the normal year and slightly higher in the dry year. Therefore, the differences between the cumulative deficits at the end of the season of both years for these alternatives are the most extreme, being $14.2 \%$ and $14 \%$, respectively.

In the normal year, higher deficits are reached within the AR(1) method, followed by ARMAX. However, in the dry year, a higher deficit is found in the ANN case, followed by EVALRISK, while AR(1) predicts lower cumulative deficits, followed by ARMAX. 
This different behaviour according to the WRS situation depends on the operating rules implemented in the AQUATOOL DSSS interface. This is analysed in the next section according to the performances of the models.

\subsection{Models performances: exceedance probabilities and expected volumes}

This section compares the assessment results from the four approaches to evaluate their predictive capacity from a decision-making perspective. This assessment was performed in terms of the exceedance probabilities and expected values of the storage volumes in the system.

In the exceedance probabilities at the end of the irrigation season (Figure 6), their predictive capacities differ between the normal and dry years. While the best method for making decisions may be the method with the highest exceedance probabilities closest to the actual volume, EVALRISK may be the most accurate approach in the normal year and ARMAX and ANN in the dry year.

In September 2004 (Figure 6a), the volume of water resources in the system was $579 \mathrm{Mm}^{3}$, which was slightly over the limit between the third and fourth volume intervals $\left(539 \mathrm{Mm}^{3}\right)$. In this case, the EVALRISK variant predicted a $40 \%$ exceedance probability for this volume, whereas for the AR(1), ANN, and ARMAX alternatives had probabilities of $20 \%, 7 \%$, and $0 \%$, respectively. Despite the higher exceedance probabilities for lower volumes in all options, EVALRISK may be the best option in this case.

In September 2006 (Figure 6b), the ARMAX and ANN variants provided a more robust result. The storage volume in the system at that time was 107 $\mathrm{Mm}^{3}$, between $0-180 \mathrm{Mm}^{3}$. While all the alternatives predict a $100 \%$ probability that the reservoir will not be empty, for the $A R(1)$ variant, the probability of exceeding $180 \mathrm{Mm}^{3}$ is $45 \%$, for EVALRISK $25 \%$, and for ARMAX and ANN $0 \%$. Therefore, for the last two alternatives, there is no doubt that the volume will be in the correct range. 


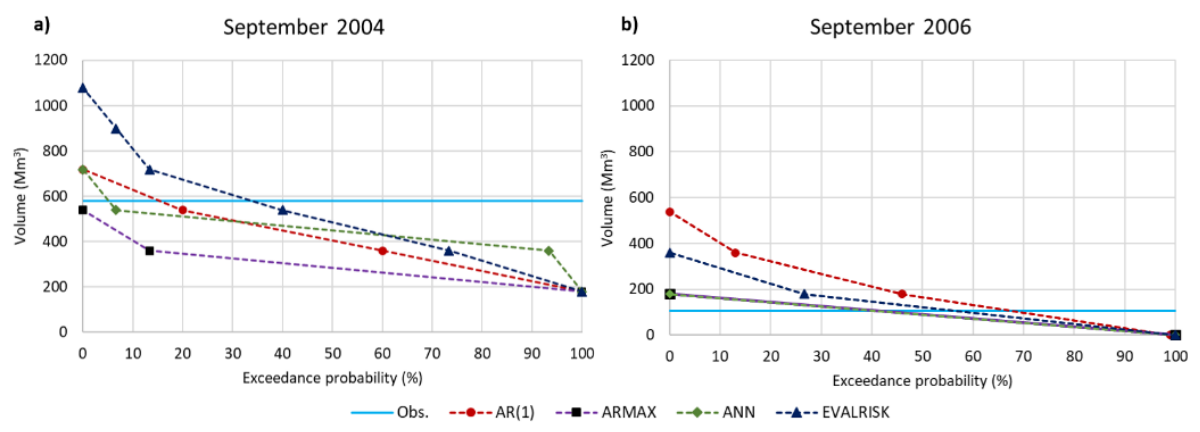

Figure 6. Exceedance probabilities from the AR(1), ARMAX, ANN and EVALRISK approaches at the end of the irrigation season of the normal (a) and dry (b) years and their comparison with the observed volumes.

Figure 7 shows a continuous comparison of the evolution of the expected volumes of all the alternatives and simulations, considering the observed values. The performance of these alternatives is shown in Table 4 through the mean values of the continuous ranked probability score (CRPS) (Zamo and Naveau, 2018), with 0 a perfect match between the forecasted and observed values.

The expected values of all the alternatives are close to the observed values, or at least in the same range of stored volumes, except for the normal year in the March generation (Figure 7). As seen in the previous results, each variant behaves differently depending on the month of generation and the hydrological characteristics of each year.

In the October prediction of the normal year (Figure 7), the values of all the alternatives are similar until December, with $A R(1)$ and EVALRISK being the closest to the observed values, although they are all within the same range (359-539 $\left.\mathrm{Mm}^{3}\right)$. From January onwards, all the variants surround those observed with more or less errors, depending on the months, but remain in the same range $\left(539-718 \mathrm{Mm}^{3}\right)$. In April, the most accurate variant is ARMAX, with a slight underestimation followed by EVALRISK, with a slight overestimation. 

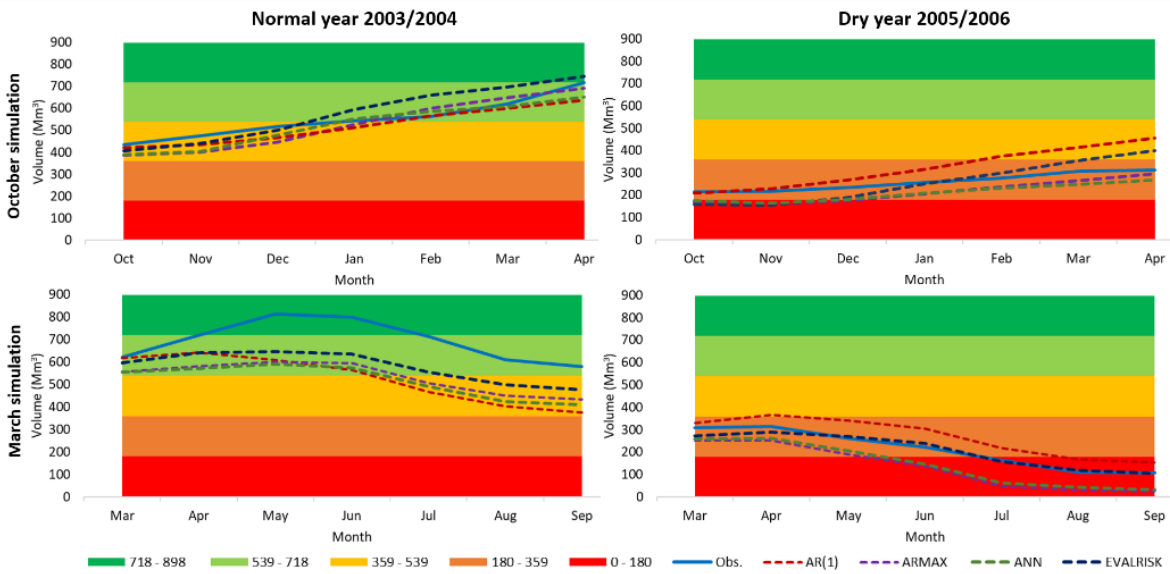

Figure 7. Expected and observed storage volumes from AR(1), ARMAX, ANN and EVALRISK approaches within $0-50 \%$ thresholds of the total storage of the system $\left(1,796 \mathrm{Mm}^{3}\right)$ for the normal and dry years, considering the October and March simulations.

In the same generation, but for the dry year (Figure 7), the variant that is in the same volumetric range (359-539 $\mathrm{Mm}^{3}$ ) at the beginning of the simulation and with values very close to those observed is the current method is AR(1). However, it progressively differs from the observed values from January onwards and in April, it forecasts more distant values with a significant overestimation because it predicts the state of the system in a higher volumetric range (359-539 $\mathrm{Mm}^{3}$ ). The other alternatives begin by slightly underestimating the observed values and at the limit between the first and second volumetric ranges $\left(0-180 \mathrm{Mm}^{3}\right.$ and $180-359 \mathrm{Mm}^{3}$, respectively) until December (month 3 ), when each one takes its own path. EVALRISK more resembles $A R(1)$ in the final months of the simulation, with a slight overestimation of the observed values and in a higher volumetric range (359-539 $\left.\mathrm{Mm}^{3}\right)$. The ARMAX and ANN alternatives present very similar values until the seventh month of the simulation, slightly underestimating the observed values but in the same range (180-359 $\mathrm{Mm}^{3}$ ), which seem the best predictors in this case.

In the March simulation of the normal year (Figure 7), all variants present an important underestimation. $A R(1)$ is the most pessimistic 
alternative at the end of the year and EVALRISK is the closest variant to the observed values, but with a notable underestimation. The variants remain in the same intervals (539-718 $\mathrm{Mm}^{3}$ and 359-539 $\mathrm{Mm}^{3}$ ) during the entire season, one less than the real ones. However, the EVALRISK alternative achieves a very good performance in the dry year, while the $A R(1)$ variant overestimates the observed values until the end of the period, and the ARMAX and ANN alternatives underestimate them, predicting very low values. All the variants are generally in the same volumetric range as the observed data.

Table 4. CRPS mean values per approach, sample year, and simulation for the expected volumes of the total storage of the system shown in Figure 6 .

\begin{tabular}{c|c|c|c|c} 
Simulation & AR(1) & ARMAX & ANN & EVALRISK \\
\hline Oct 2003 & $\mathbf{3 4 . 0 4}$ & 42.99 & 38.07 & 48.36 \\
\hline Mar 2004 & 167.32 & 161.06 & 176.89 & $\mathbf{1 1 4 . 8 4}$ \\
\hline Oct 2005 & 65.76 & $\mathbf{4 3 . 6 7}$ & 46.91 & 48.80 \\
\hline Mar 2006 & 56.31 & 78.66 & 67.67 & $\mathbf{1 4 . 9 0}$
\end{tabular}

The CRPS mean values in Table 4 agree that the best predictor for the March simulations is EVALRISK, despite the poor performance in the normal year. This may be because this model contains more information than the others because it considers the influence of the groundwater variant, and the initial conditions of the system are known. In contrast, for the October simulations, there is no clear pattern. However, for this simulation in the dry year, it appears that all alternatives but the $A R(1)$ have similar performances, with ARMAX being the best predictor.

These results highlight the improvement provided by the seasonal forecasts for drought periods, either integrated directly into a model (EVALRISK) or as a result of their combination with historical inflows (ARMAX). They show a greater predictive capacity than the current method in most cases. 


\section{Discussion}

The results of this study demonstrate that the methodological options proposed for the inclusion of seasonal forecasts in real-time drought management are promising because their predictive capacities are generally superior to those of the current method, especially in the dry year, when a good prediction is essential. Some of these variants slightly underestimate real volumes, which from a drought management perspective is better than overestimating them, as in variant $A R(1)$, because decisions are taken from a safety perspective. However, they do not differ significantly and further research is needed to test more historical periods, use other post-processing techniques (Grillakis et al., 2017; Macian-Sorribes et al., 2020) and seasonal forecasts with larger ensemble members to provide higher quality predictions, but at the same time introduce more uncertainty into the process (Li et al., 2017).

Important decisions and findings from the risk assessment process can be discussed because the selection of the approaches was based on previous studies with similar purposes (García-Romero et al., 2019; HaroMonteagudo et al., 2017; Madrigal Barrera, 2020; Ochoa-Rivera, 2002; Pujol Reig, 2009; Sánchez-Quispe et al., 2001) and most of them were conducted in the JRB and achieved good performances. Similarly, the indicator of the water storage evolution was chosen because of its connection with the SSI of the DMP because the reservoir storage represents almost $50 \%$ of the SSI value (Haro-Monteagudo et al., 2017; Suárez-Almiñana et al., 2020). Therefore, the proposed indicator can offer an approximation of the SSI at first glance and complement it because it is very easy for stakeholders to understand.

With the evaluation of the testing periods, a joint vision of the system is obtained from two very different situations, with one being normality and another being extreme drought. The extreme drought situation highlights the importance of comprehensive and efficient drought management 
because the scenarios depicted in Figure 5 and Table 2 for the dry year are unsustainable situations of extreme risk.

In the case of the indicators, if only the previous inputs or the seasonal forecasts are used for inflow series generation (AR(1) and EVALRISK approaches), the variability of the prediction is higher. However, when these data are used together, there is less variability and perhaps a better fit to the observed data, especially at the end of the simulation. This is the case for the ARMAX and ANN approaches, where predictions in the indicators coincide in the volumetric range at the end of the October simulation and at the beginning of the March simulation (Figures 4 and 5).

This low variability may indicate that with the use of combined input data for the generation of inflow series, the results of the risk assessment could be more robust and able to predict with acceptable accuracy at more than three months. However, this lack of variability may also indicate that there are few ensemble members, or that this variability is limited by bias correction (Madrigal Barrera, 2020).

Conversely, EVALRISK has the best performance in March simulations (Figure 7) (Table 4). This may be due to better seasonal forecast skills in the spring and summer seasons after the bias correction, as well as the use of a hydrological model adapted to this basin, whose initial conditions are known for this period after a testing simulation of the management model. The performances of these models and the skill of their hydrological outputs are highly dependent on the initial conditions (Arnal et al., 2018; Wanders et al., 2019).

In the last few years, large-scale hydrological models have been used to extract hydrological forecasts (Arnal et al., 2018; Crochemore et al., 2020; Hundecha et al., 2016), and substantially improved inflow skills have been achieved for up to three months (Arnal et al., 2018; Crochemore et al., 2020; Grillakis et al., 2018; Li et al., 2017; Macian-Sorribes et al., 2020; Wanders et al., 2019). However, these models may not capture the 
characteristics of smaller and more complex basins whose main inflows depend largely on the groundwater component, as is the case in the JRB (Suárez-Almiñana et al., 2017). This study demonstrates how the use of a well-calibrated hydrological model that strictly represents the characteristics of the basin may be more appropriate for inflow extraction and risk assessment. Notably, the management/risk assessment model has the operating rules of the WRS integrated, which means that supply restrictions are applied directly when inflows are low. However, the volumes observed in Figure 7 correspond to the measures taken at that moment, which may not coincide exactly with the measures adopted by the model, so in this respect, there is also uncertainty regarding which method has better predictive capacity.

The good predictive capacities of EVALRISK are due to the high degree of development of the models. The conclusion could be different for systems where there is less experience in water resource management or simply because there is not enough data to properly calibrate a hydrological model.

In view of the results presented in this study, all the approaches must continue to be improved and recalibrated in the future because they offer very good expectations for real-time drought management. For example, some studies have stated that for long-term flow predictions, the performance of ANN is questionable (Pujol Reig, 2009). In this case, it would be better to create an ANN model for wet periods and another for dry periods in addition to testing more complex algorithms, such as back propagation (Rojas, 1996). Moreover, a seasonal ARMAX can be implemented considering $T$ as an exogenous variable (Pujol Reig, 2009).

According to Lavers et al. (2020), seasonal forecast skill can be improved through wider earth system monitoring, the inclusion of methodological advances in hydrological predictions, and better communication between forecasters and users, therefore, obtaining socioeconomic benefits. However, these advances do not guarantee their use if water managers do 
not trust them when real-time seasonal forecasts are available. Furthermore, if they are not freely available this is an economic factor to be taken into account for their use in the JRB (Arnal et al., 2016).

The methodologies used in this study are the first step in managing systems in advance, with skilful forecasts in real time. This contrasts with the current practice, which is palliative or preventive management that takes actions by imitating previous experiences. Who knows if having this knowledge and advanced techniques previously could have prevented the severe impacts of the 2005-2008 drought in the JRB.

\section{Conclusions}

In this study, several approaches for real-time drought management, including seasonal forecasts in the process were presented to analyse their added value in decision-making and compare to current methodologies. These approaches were the hydrological, ARMAX, and ANN models for inflow series generation prior to risk assessment, where the drought risk indicator on the probabilistic evolution of the system's water resources was extracted for one period before the extreme drought event in 2005-2008 in the JRB (normal year 2003/2004) and also for one period of immersion during this drought (dry year 2005/2006). In addition, two simulations per year were tested, and were initiated in October (beginning of the hydrological year) and March (beginning of the irrigation season) to determine the state of the system seven months in advance. This incorporated the previous months for the irrigation season and the final state of the system after this season, which are key points for decisionmaking.

The experience of the JRB in drought management is based on stochastic processes that use historical inflow statistics as input data for inflow series generation, which in this case was the ARMA model. This current method served as a reference in this study, because it does not integrate forecasts in the process. 
After the comparison of risk assessment results from the proposed and current methods with observed values, the main results confirmed the possibility of improving the predictive capacity of current methods because of seasonal forecasts, especially after the application of post-processing techniques (bias correction) and the use of robust and well-calibrated models at the basin scale, such as the EVALRISK alternative. However, in other basins where complex models are not available, or the data available for their calibration are insufficient, ARMAX and ANN are good options for risk assessment because they combine both input data with good results. In the latter cases of ARMAX and ANN, the results are more robust, with lower variabilities and uncertainty after seven months. Moreover, in the dry year simulations, these methods slightly underestimated the observed values, which is an advantage from the point of view of drought management because some measures could be applied from a safety perspective.

The proposed methods offer high expectations for future real-time drought management, but more research is needed, both for the improvement of the models presented and the seasonal forecasts. This is because they have yet to gain the confidence of decision-makers, which is necessary to guarantee their use when they are available in real time.

\section{Acknowledgments}

The authors thank AEMET and UC (Universidad de Cantabria) for the data provided for this work (Spain02 v5 dataset, available at http://www.meteo.unican.es/datasets/spain02) and the Research and Development Support Programme (PAID-01-17) from the Universitat Politècnica de València for encouraging and facilitating training contracts for research staff.

\section{Funding sources}

This research was supported by the Spanish Research Agency (MICINN) and the European Community in financing the RESPHIRA (PID2019- 
106322RB-100) and IMPREX (H2020-WATER-2014-2015, 641811) projects respectively.

\section{References}

Andreu, J., Capilla, J., Sanchís, E., 1996. AQUATOOL, a generalized decision-support system for water-resources planning and operational management. J. Hydrol. 177, 269-291. doi:10.1016/0022-1694(95)02963-X

Andreu, J., Ferrer-Polo, J., Pérez, M.A., Solera, A., 2009. Decision support system for drought planning and management in the Jucar river basin, Spain, in: Proceedings of the 18th world IMACS/MODSIM Congress, 13-17 July 2009, Cairns, Australia, 3223-3229.

Andreu, J., Pérez, M.A., Ferrer, J., Villalobos, A., Paredes, J., 2007. Drought management decision support system by means of risk analysis models, in: Rossi, G., Vega, T., Bonaccorso, B. (Eds.), Methods and Tools for Drought Analysis and Management. Springer, The Netherlands, pp. 195-216.

Andreu, J., Solera, A., 2006. Methodology for the analysis of drought mitigation measures in water resource systems, in: Andreu, J., Rossi, G., Vagliasindi, F., Vela, A. (Eds.), Drought Management and Planning for Water Resources. Taylor \& Francis, Boca Raton, pp. 133-168.

Arlot, S., Celisse, A., 2010. A survey of cross-validation procedures for model selection. Stat. Surv. 4, 40-79. doi:10.1214/09-SS054

Arnal, L., Cloke, H.L., Stephens, E., Wetterhall, F., Prudhomme, C., Neumann, J., Krzeminski, B., Pappenberger, F., 2018. Skilful seasonal forecasts of streamflow over Europe? Hydrol. Earth Syst. Sci. 22, 2057-2072. doi:10.5194/hess-22-2057-2018

Arnal, L., Ramos, M.H., De Perez, E.C., Cloke, H.L., Stephens, E., Wetterhall, F., Van Andel, S.J., Pappenberger, F., 2016. Willingness-to-pay for a probabilistic flood forecast: A risk-based decision-making game. Hydrol. Earth Syst. Sci. 20, 31093128. doi:10.5194/hess-20-3109-2016

Barranco, L., Dimas, M., Jiménez, A., Estrada, F., 2018. Nueva evaluación del impacto futuro del cambio climático en los recursos hídricos en España. Ingeiría Civ. 191/2008, 34-55. 
Bergström, S., 1995. The HBV Model, in: Computer Models of Watershed HyDrology, Water Resources Publications, Highlands Ranch. Colorado, pp. 443476.

Box, G., Jenkins, G., Reinsel, G., Ljung, G., 2016. Time Series Analysis: Forecasting and Control. Wiley, Hoboken, New Jersey.

CHJ, 2018. Drought Management Plan for the Júcar River Basin District (in spanish), Ministerio de Agricultura y Pesca, Alimentación y Medio Ambiente, Valencia, Spain.

https://www.chj.es/Descargas/ProyectosOPH/RevisionPES/PES_2017_DHJ.pdf (last access: 24 February 2021).

CHJ, 2015. Júcar River Basin District Management Plan, Hydrological Planning Report 2015-2021 (in spanish), Ministerio de Agricultura, Alimentación y Medio Ambiente, Valencia, Spain. https://www.chj.es/eses/medioambiente/planificacionhidrologica/Documents/Plan-Hidrologicocuenca-2009-2015/PHJ09_Memoria_13julio.pdf (last access: 24 February 2021).

CHJ, 2010. Post-drought 2005-2008 report. Section 10 DMP (in spanish),Ministerio de Medio Ambiente y Medio Rural y Marino, Valencia, Spain. https://www.chj.es/es-

es/medioambiente/gestionsequia/Documents/Informes\%20Seguimiento/INF ORME_POST_SEQUIA_2010.pdf (last access: 24 February 2021).

Crochemore, L., Ramos, M.H., Pappppenberger, F., Van Andel, S.J., Wood, A.W., 2016. An experiment on risk-based decision-making in water management using monthly probabilistic forecasts. Bull. Am. Meteorol. Soc. 97, 541-551. doi:10.1175/BAMS-D-14-00270.1

Crochemore, L., Ramos, M.H., Pechlivanidis, I.G., 2020. Can Continental Models Convey Useful Seasonal Hydrologic Information at the Catchment Scale? Water Resour. Res. 56, 1-21. doi:10.1029/2019WR025700

EP (European Parliament), 2000. Directive 2000/60/EC of the European Parliament and of the Council of 23 October 2000 Establishing a Framework for Community Action in the Field of Water Policy. Official Journal, Brussels.

Espadafor, M., Lorite, I.J., Gavilán, P., Berengena, J., 2011. An analysis of the tendency of reference evapotranspiration estimates and other climate variables during the last 45 years in Southern Spain. Agric. Water Manag. 98, 1045-1061. doi:10.1016/j.agwat.2011.01.015 
Estrela, T., Sancho, T.A., 2016. Drought management policies in Spain and the European Union: from traditional emergency actions to Drought Management Plans. Water Policy 18, 153-176. doi:10.2166/wp.2016.018

Estrela, T., Vargas, E., 2012. Drought Management Plans in the European Union. The Case of Spain. Water Resour. Manag. 26, 1537-1553. doi:10.1007/s11269-011-9971-2

García-Romero, L., Paredes-Arquiola, J., Solera, A., Belda, E., Andreu, J., SánchezQuispe, S.T., 2019. Optimization of the multi-start strategy of a direct-search algorithm for the calibration of different rainfall-runoff models for the water resources assessment. Water, 11, 1876. doi:10.3390/w11091876

Govindaraju, R.S., Rao, A.R., 2000. Artificial neural networks in hydrology. Kluwer Academic Publishers, Dordrecht, Netherlands.

Grillakis, M., Koutroulis, A., Tsanis, I., 2018. Improving seasonal forecasts for basin scale hydrological applications. Water 10(11), 1593. doi:10.3390/w10111593

Grillakis, M.G., Koutroulis, A.G., Daliakopoulos, I.N., Tsanis, I.K., 2017. A method to preserve trends in quantile mapping bias correction of climate modeled temperature. Earth Syst. Dyn. 8, 889-900. doi:10.5194/esd-8-889-2017

Groot, S., Wegman, C., Schasfoort, F., Andreu, J., Solera, A., Suárez-Almiñana, S., 2019. Application of multihazard drought risk management tool. IMPREX project report, Netherlands.

Gudmundsson, L., Bremnes, J.B., Haugen, J.E., Engen-Skaugen, T., 2012. Technical Note: Downscaling RCM precipitation to the station scale using statistical transformations - a comparison of methods. Hydrol. Earth Syst. Sci. 16, 33833390. doi:10.5194/hess-16-3383-2012

Hargreaves, G.H., Samani, Z.A., 1985. Reference crop evapotranspiration from temperature. Appl. Eng. Agric. 1 (2), 96-99.

Haro-Monteagudo, D., 2014. Methodology for the optimal management design of water resources system under hydrologic uncertainty. PhD thesis, Universitat Politècnica de València, Valencia, Spain, $373 \mathrm{pp}$.

Haro-Monteagudo, D., Solera, A., Andreu, J., 2017. Drought early warning based on optimal risk forecasts in regulated river systems: Application to the Jucar River Basin (Spain). J. Hydrol. 544, 36-45. doi:10.1016/j.jhydrol.2016.11.022 
Hernández Bedolla, J., Solera, A., Paredes Arquiola, J., Roblero Escobar, C.X., 2019. Análisis del cambio en las aportaciones hidrológicas en la cuenca del río Júcar a partir de 1980 y sus causas. Ing. del agua 23, 141-155. doi:10.4995/ia.2019.10582

Herrera, S., Fernández, J., Gutiérrez, J.M., 2016. Update of the Spain02 gridded observational dataset for EURO-CORDEX evaluation: Assessing the effect of the interpolation methodology. Int. J. Climatol. 36, 900-908. doi:10.1002/joc.4391

Higham, D.J., Higham, N.J., 2016. MATLAB guide (Vol. 150). Society for Industrial and Applied Mathematics, Philadelphia, PA, USA.

Hundecha, Y., Arheimer, B., Donnelly, C., Pechlivanidis, I., 2016. A regional parameter estimation scheme for a pan-European multi-basin model. J. Hydrol. Reg. Stud. 6, 90-111. doi:10.1016/j.ejrh.2016.04.002

Hunink, J., Andreu, J., Castelletti, A., Crochemore, L., Giuliani, M., Grillakis, M., Koutroulis, A., Pechlivanidis, I., Solera, A., Suárez-Almiñana, S. Tsanis, I., de Tomás, A., Hamed, R., 2019. Demonstration and evaluation of prototype of Drought Decision Support systems. IMPREX project report, Cartagena, Spain.

Hunink, J., Simons, G., Suárez-Almiñana, S., Solera, A., Andreu, J., Giuliani, M., Zamberletti, P., Grillakis, M., Koutroulis, A., Tsanis, I., Schasfoort, F., Contreras, S., Ercin, E., Bastiaanssen, W., 2019. A simplified water accounting procedure to assess climate change impact on water resources for agriculture across different European river basins. Water 11(10), 1976. doi:10.3390/w11101976

IPCC, 2014. Summary for Policymakers, Climate Change 2014: Synthesis Report. Contribution of Working Groups I, II and III to the Fifth Assessment Report of the Intergovernmental Panel on Climate Change. Geneva, Switzerland. doi:10.1017/СВ09781107415324

Kotlarski, S., Szabó, P., Herrera, S., Räty, O., Keuler, K., Soares, P.M., Cardoso, R.M., Bosshard, T., Pagé, C., Boberg, F., Gutiérrez, J.M., Isotta, F.A., Jaczewski, A., Kreienkamp, F., Liniger, M.A., Lussana, C., Pianko-Kluczyńska, K., 2017. Observational uncertainty and regional climate model evaluation: A panEuropean perspective. Int. J. Climatol. 39, 3730-3749. doi:10.1002/joc.5249

Lavers, D.A., Ramos, M.H., Magnusson, L., Pechlivanidis, I., Klein, B., Prudhomme, C., Arnal, L., Crochemore, L., Hurk, B. Van Den, Weerts, A.H., Harrigan, S., Cloke, H.L., Richardson, D.S., Pappenberger, F., 2020. A vision for hydrological prediction. Atmosphere. 11, 1-12. doi:10.3390/atmos11030237 
Lenderink, G., Buishand, A., Van Deursen, W., 2007. Estimates of future discharges of the river Rhine using two scenario methodologies: direct versus delta approach. Hydrol. Earth Syst. Sci. 11, 1145-1159.

Li, Y., Giuliani, M., Castelletti, A., 2017. A coupled human-natural system to assess the operational value of weather and climate services for irrigated agriculture. Hydrol. Earth Syst. Sci. Discuss. 1-27. doi:10.5194/hess-2017-304

Liu, J., Yang, H., Gosling, S.N., Kummu, M., Flörke, M., Pfister, S., Hanasaki, N., Wada, Y., Zhang, X., Zheng, C., Alcamo, J., Oki, T., 2017. Water scarcity assessments in the past, present, and future. Earth's Futur. 5, 545-559. doi:10.1002/2016EF000518

Ljung, L., 1999. System Identification: Theory for the User, Second Edition, PrenticeHall PTR, Upper Saddle River, NJ.

Macian-Sorribes, H., Pechlivanidis, I., Crochemore, L., Pulido-Velazquez, M., 2020. Fuzzy postprocessing to advance the quality of continental seasonal hydrological forecasts for river basin management. J. Hydrometeorol. 21, 2375-2389. doi:10.1175/JHM-D-19-0266.1

Madrigal Barrera, J., 2020. Análisis de pronósticos climáticos para la previsión de sequías meteorológicas e hidrológicas. PhD thesis, Universitat Politècnica de València, Valencia, Spain, $242 \mathrm{pp}$.

Madrigal, J., Solera, A., Suárez-Almiñana, S., Paredes-Arquiola, J., Andreu, J., Sánchez-Quispe, S.T., 2018. Skill assessment of a seasonal forecast model to predict drought events for water resource systems. J. Hydrol. 564, 574-587. doi:10.1016/j.jhydrol.2018.07.046

Milly, P.C.D., Dunne, K.A., 2017. A Hydrologic Drying Bias in Water-Resource Impact Analyses of Anthropogenic Climate Change. J. Am. Water Resour. Assoc. 53, 822-838. doi:10.1111/1752-1688.12538

Molteni, F., Stockdale, T., Balmaseda, M.A., Balsamo, G., Buizza, R., Ferranti, L., Magnusson, L., Mogensen, K., Palmer, T., Vitart, F., 2011. The new ECMWF seasonal forecast system (System 4). Tech. Memo, Reading, UK.

Moriasi, D.N., Arnold, J.G., Van Liew, M.W., Bingner, R.L., Harmel, R.D., Veith, T.L., 2007. Model Evaluation Guidelines for Systematic Quantification of Accuracy in Watershed Simulations. Trans. ASABE 50, 885-900. doi:10.13031/2013.23153 
Ochoa-Rivera, J.C., 2008. Prospecting droughts with stochastic artificial neural networks. J. Hydrol. 352, 174-180. doi:10.1016/j.jhydrol.2008.01.006

Ochoa-Rivera, J.C., 2002. Modelo Estocástico de Redes Neuronales para la Síntesis de Caudales Aplicados a la Gestión Probabilística de Sequías. PhD thesis, Universitat Politècnica de València, Valencia, Spain, 226 pp.

Ortega-Gómez, T., Pérez-Martín, M.A., Estrela, T., 2018. Improvement of the drought indicators system in the Júcar River Basin, Spain. Sci. Total Environ. 610-611, 276-290. doi:10.1016/j.scitotenv.2017.07.250

Palop-Donat, C., Paredes-Arquiola, J., Andreu, J., 2020. Optimization of the Scarcity State Indicator in the Jucar river basin. Rev. Ing. del Agua 24(2), 129-140.

Paredes-Arquiola, J., Solera, A., Andreu, J., Lerma, N., 2012. Technical Manual of the EVALHID tool for water resources assessment (in spanish), Universitat Politècnica de València, Valencia, Spain. https://aquatool.webs.upv.es/files/manuales/aquatool/Manual_Tecnico_Eval Hid.pdf (last access: 24 February 2021).

Pedro-Monzonís, M., Solera, A., Ferrer, J., Estrela, T., Paredes-Arquiola, J., 2015. A review of water scarcity and drought indexes in water resources planning and management. J. Hydrol. 527, 482-493. doi:10.1016/j.jhydrol.2015.05.003

Pianosi, F., Soncini-Sessa, R., 2009. Real-time management of a multipurpose water reservoir with a heteroscedastic inflow model. Water Resour. Res. 45(10), W10430. doi:10.1029/2008WR007335

Pujol Reig, L., 2009. Predicciones de caudales en tiempo real en grandes cuencas utilizando redes neuronales artificiales. PhD thesis, Universitat Politècnica de València, Valencia, Spain, 318 pp.

R Core Team, 2020. R: A language and environment for statistical computing. R Foundation for Statistical Computing, Vienna, Austria.

Ramezan, C.A., Warner, T.A., Maxwell, A.E., 2019. Evaluation of Sampling and Cross-Validation Tuning Strategies for Regional-Scale Machine Learning Classification. Remote Sens. 11, 185. doi:10.3390/rs11020185

Rojas, R., 1996. Neural Networks: A systematic Introduction. Springer, Berlin, Germany.

Salas, J.D., Delleur, J.W., Yevjevich, V.M., Lane, W.L., 1980. Applied Modeling of Hydrologic Time Series. Water Resour. Publ. Littleton, Color. USA. 
Sánchez-Quispe, S., Andreu, J., Solera, A., 2001. Gestión de Recursos Hídricos con Decisiones Basadas en Estimación del Riesgo. PhD thesis, Universitat Politècnica de València, Valencia, Spain.

Suárez-Almiñana, S., Pedro-Monzonís, M., Paredes-Arquiola, J., Andreu, J., Solera, A., 2017. Linking Pan-European data to the local scale for decision making for global change and water scarcity within water resources planning and management. Sci. Total Environ. 603-604, 126-139. doi:10.1016/j.scitotenv.2017.05.259

Suárez-Almiñana, S., Solera, A., Madrigal, J., Andreu, J., Paredes-arquiola, J., 2020. Risk assessment in water resources planning under climate change at the Júcar River Basin. Hydrol. Earth Syst. Sci. 24, 5297-5315. doi:https://doi.org/10.5194/hess-24-5297-2020

Teutschbein, C., Seibert, J., 2012. Bias correction of regional climate model simulations for hydrological climate-change impact studies: Review and evaluation of different methods. J. Hydrol. 456-457, 12-29. doi:10.1016/j.jhydrol.2012.05.052

Venables, W.N., Ripley, B.D., 2002. Modern Applied Statistics with S., Fourth edition. Springer, New York, USA.

Wanders, N., Thober, S., Kumar, R., Pan, M., Sheffield, J., Samaniego, L., Wood, E.F., 2019. Development and evaluation of a pan-European multimodel seasonal hydrological forecasting system. J. Hydrometeorol. 20, 99-115. doi:10.1175/JHM-D-18-0040.1

Wetterhall, F., Di Giuseppe, F., 2017. The benefit of seamless forecasts for hydrological predictions over Europe. Hydrol. Earth Syst. Sci. Discuss. 4, 1-17. doi:10.5194/hess-2017-527

Zamo, M., Naveau, P., 2018. Estimation of the Continuous Ranked Probability Score with Limited Information and Applications to Ensemble Weather Forecasts. Math. Geosci. 50, 209-234. doi:10.1007/s11004-017-9709-7 


\subsubsection{Otros artículos}

Como parte del trabajo en equipo desarrollado en el Grupo de Ingeniería de Recursos Hídricos (GIRH) y en el proyecto IMPREX, se ha colaborado en las siguientes publicaciones centradas en el uso de los servicios climáticos con diversos fines, todos ellos relacionados con la gestión de los recursos hídricos:

- Andreu, J., Suárez-Almiñana, S., Paredes, J. y Solera, A. (2019) "Uso de servicios climáticos en cuencas propensas a la sequía: Proyecto IMPREX y cuenca del Júcar" en iAgua, 30 de septiembre. $<$ https://www.iagua.es/blogs/joaquin-andreu-alvarez/uso-serviciosclimaticos-cuencas-propensas-sequia-proyecto-imprex-y> [Consulta: 16 de junio de 2020].

- Madrigal, J., Solera, A., Suárez-Almiñana, S., Paredes-Arquiola, J., Andreu, J., Sánchez-Quispe, S. T. (2018): Skill assessment of a seasonal forecast model to predict drought events for water resource systems. J. Hydrol., 564(February), 574-587, doi:10.1016/j.jhydrol.2018.07.046.

- Hunink, J., Simons, G., Suárez-Almiñana, S., Solera, A., Andreu, J., Giuliani, M., Zamberletti, P., Grillakis, M., Koutroulis, A., Tsanis, I., Schasfoort, F., Contreras, S., Ercin, E., Bastiaanssen, W. (2019): A simplified water accounting procedure to assess climate change impact on water resources for agriculture across different European river basins. Water, 11(10), 1-29, doi:10.3390/w11101976.

- Samuel Williams, D., Máñez Costa, M., Kovalevsky, D., van den Hurk, B., Klein, B., Meissner, D., Pulido-Velazquez, M., Andreu, J., SuárezAlmiñana, S. (2020): A method of assessing user capacities for effective climate services. Climate Services, 19 (100180), 1-10, doi.org/10.1016/j.cliser.2020.100180. 


\subsubsection{Participación en congresos nacionales e internacionales}

Los trabajos relacionados con esta tesis han sido también difundidos por medio de varias presentaciones orales y posters en congresos de ámbito nacional e internacional, así como en varias colaboraciones fruto del trabajo en equipo desarrollado en el GIRH y en el proyecto IMPREX. Se listan a continuación:

- Suárez-Almiñana, S.; Solera Solera, A.; Andreu Álvarez, J.; GarciaRomero, L. (2019). Análisis de incertidumbre de las proyecciones climáticas en relación a las aportaciones históricas en la Cuenca del Júcar. EN: VI Jornadas de Ingeniería del Agua (JIA 2019). Toledo, España: Universidad de Castilla-La Mancha.

- Madrigal-Barrera, J. J.; Suárez-Almiñana, S.; Solera Solera, A. (2019). Corrección del sesgo de pronósticos estacionales para su uso en la predicción de sequías. EN: VI Jornadas de Ingeniería del Agua (JIA 2019). Toledo, España: Universidad de Castilla-La Mancha.

- Suárez-Almiñana, S.; Solera Solera, A.; Andreu Álvarez, J.; MadrigalBarrera, J. J. (2019). Assessment of the future drought risk management through probabilistic reservoir storage indicators in the Júcar River Basin (Spain). IN: 4th European Climate Change Adaptation Conference (ECCA 2019). Lisboa, Portugal.

- Andreu Álvarez, J.; Solera Solera, A.; Suárez-Almiñana, S.; MadrigalBarrera, J. J.; Paredes Arquiola, J. (2019). Management of complex water resources systems under global change. IN: 11th WORLD CONGRESS of EWRA on Water Resources and Environment (EWRA2019). Managing Water Resources for a Sustainable Future. Madrid, España: EWRA Editorial Office.

- Suárez-Almiñana, S.; Solera Solera, A.; Andreu Álvarez, J.; MadrigalBarrera, J. J. (2018). The use of Water Accounting techniques in the study of climate change effects for basin planning in the Júcar River Basin. Póster. EN: II Encuentro Internacional Procesos de Soporte a la Decisión para la Gestión Participativa del Agua. Valencia, España. 
- Suárez-Almiñana, S.; Solera Solera, A.; Andreu Álvarez, J.; MadrigalBarrera, J. J. (2018). Uso de las técnicas de Water Accounting en el estudio de los efectos del cambio climático para la planificación de cuencas en la Cuenca del Júcar. EN: II Encuentro Internacional Procesos de Soporte a la Decisión para la Gestión Participativa del Agua. Valencia, España.

- Madrigal-Barrera, J. J.; Solera Solera, A.; Suárez-Almiñana, S. (2018). Análisis de pronósticos climáticos para su uso en la predicción de sequías meteorológicas. EN: II Encuentro Internacional Procesos de Soporte a la Decisión para la Gestión Participativa del Agua. Valencia, España.

- Madrigal-Barrera, J. J.; Suárez-Almiñana, S.; Garcia-Romero, L.; Solera Solera, A. (2018). Análisis de Pronósticos Climáticos para Su Uso en la Gestión de Recursos Hídricos. EN: X Congreso Iberico de Gestion y Planificacion del Agua. (1 - 10). Coimbra, Portugal: Universidad de Coimbra.

- Suárez-Almiñana, S.; Solera Solera, A.; Pedro Monzonis, M.; Andreu Álvarez, J.; Estrela Monreal, T. (2016). Linking Pan-European data to local scale for decision making within global change and water scarcity. IN: NET-SCARCE International Conference. Rivers Under Water Scarcity: Threats and Challenges. Barcelona, España.

\subsubsection{Informes públicos del proyecto IMPREX}

Debido a la vinculación de esta tesis con el proyecto IMPREX, se ha colaborado en varios informes durante su periodo activo, donde se exponen los logros desarrollados en las fases tempranas de esta tesis. Estos informes se centran en la calidad e idoneidad de los datos meteorológicos e hidrológicos aportados y su utilidad en la gestión del agua, así como en el desarrollo de metodologías e indicadores para la respuesta temprana ante eventos extremos como las sequías, sobre todo en el sector agrícola. También se tiene en cuenta el desarrollo e implementación de SSD y temas relacionados con la calidad del agua. 
Gran parte de ellos se encuentran disponibles en la web del proyecto (www.imprex.eu), a continuación se presenta un listado:

- Andreu, J., Solera, A., Suárez-Almiñana, S., Pedro-Monzonís, M., Pulido-Velázquez, M., Macián-Sorribes, H., Rubio-Martín, A. (2018). Prototype hydrological module. Universitat Politècnica de València, Spain.

<https://www.imprex.eu/index.php/system/files/generated/files/res ource/d13-3-imprex-final.pdf> [Consulta: 01 de junio de 2020].

- Arnal, L., Cloke, H. L., Magnusson, L., Klein, B., Meissner, D., de Tomas, A., Hunink, J., Pechlivanidis, I., Crochemore, L., SuárezAlmiñana, S., Solera, A., Andreu, J., Knight, J., Liggins, F., Weerts, A., Ramos, M.H., Thirel, G. (2017). The sensitivity of sub-seasonal to seasonal streamflow forecasts to meteorological forcing quality, modelled hydrology and the initial hydrological conditions. University of Reading,

UK. <https://www.imprex.eu/index.php/system/files/generated/files/res ource/d4-2-imprex-v1-0.pdf> [Consulta: 01 de junio de 2020].

- de Moel, H., Albers, E., Guimarães Nobre, G., Hunink, J., van Vuren, S., Schasfoort, F., Mens, M., Kramer, N., Lüdtke, S., Kreibich, H., Andreu, J., Solera, A., Suárez-Almiñana, S. (2018). Advances in novel concepts in hydro-meteorological risk assessments. Stichting VUVUMC, Netherlands. $<$ https://www.imprex.eu/index.php/system/files/generated/files/res ource/deliverable5-2-imprex-v1-0.pdf> [Consulta: 01 de junio de 2020].

- de Moel, H., Tiggeloven, T., Schasfoort, F., Mens, M., Delsman, J., van der Vat, M., Groot, S., van Vuren, S., Honingh, D., Versteeg, R., van der Vat, M., Delsman, J., Lugt, D., Albers, E., Guimarães Nobre, G., Andreu, J., Suárez-Almiñana, S., Paredes, J., Solera, A., Steinhausen, M., Lüdtke, S., Schröter, K., Figueiredo, R., Kreibich, H. (2019). Final Deliverables on Novel Concepts. Stichting VU-VUMC, Netherlands. 
- Falloon, P., William, K., Andreu, J., Solera, A., Suárez-Almiñana, S., Klein, B., Meissner, D., Hunink, J., Eekhout, J., de Vente, J. (2019). Estimation of hazards based on improved representation of highly vulnerable water resources of strategic importance on the climate scale. MetOffice,

UK. <https://www.imprex.eu/index.php/system/files/generated/files/res ource/imprex-deliverablereport-d4-4-final-1.pdf> [Consulta: 01 de junio de 2020].

- Fernandez, S., Hurtado, I., Suárez-Almiñana, S., Solera, A., Paredes, J., Andreu, J., Pouget, L. (2018). Impact in Segura and Llobregat basins: Use of predictions in the urban water sector and impact in the management of surface water quality changes driven by hydroclimatic conditions. CETAQUA, Spain. $<$ https://www.imprex.eu/index.php/system/files/generated/files/res ource/deliverable10-2-imprex-v1-0_0.pdf> [Consulta: 01 de junio de 2020].

- Groot, S., Wegman, C., Schasfoort, F., Andreu, J., Solera, A., SuárezAlmiñana, S. (2019). Application of multihazard drought risk management tools. HKV Lijn in water BV, Netherlands. <https://www.imprex.eu/index.php/system/files/generated/files/res ource/deliverable11-3-imprex-v2-0.pdf> [Consulta: 01 de junio de 2020].

- Hunink, J., Andreu, J., Castelletti, A., Crochemore, L., Giuliani, M., Grillakis, M., Koutroulis, A., Pechlivanidis, I., Solera, A., SuárezAlmiñana, S., Tsanis, I., de Tomás, A., Hamed, R. (2019). Demonstration and evaluation of prototype of Drought Decision Support systems. FutureWater, Spain. <https://www.imprex.eu/index.php/system/files/generated/files/res ource/d11-4-imprex-prototype-drought-dss-v1-1.pdf> [Consulta: 01 de junio de 2020].

- Hunink, J., Contreras, S., Hamed, R., Castelletti, A., Giuliani, M., Zaniolo, M., Andreu, J., Solera, A., Suárez-Almiñana, S., Koutroulis, A., Grillakis, M., Tsanis, I., Guimarães Nobre, G., Aerts, J., Ward, P. J., 
Turco, M., García-León, D., Baruth, B. (2019). Index-based drought risk assessment: Exploration of drought indices and agricultural impacts. FutureWater, Spain. <https://www.imprex.eu/index.php/system/files/generated/files/res ource/deliverable11-2-imprex-v2-0.pdf> [Consulta: 01 de junio de 2020].

- Hunink, J., de Tomás, A., Li, Y., Castelletti, A., Giuliani, M., Giudici, F., Suárez-Almiñana, S., Andreu, J., Koutroulis, A., Grillakis, M., Solera, A. (2017). Prototype design of drought Decision Support Systems. FutureWater, Spain. $<$ https://www.imprex.eu/index.php/system/files/generated/files/res ource/d11-1-imprex-v2-0.pdf> [Consulta: 01 de junio de 2020].

- Hunink, J., Simons, G., Suárez-Almiñana, S., Solera, A., Andreu, J., Giuliani, M., Zamberletti, P., Grillakis, M., Koutroulis, A., Tsanis, I., Schasfoort, F., Contreras, S., Ercin, E., Bastiaanssen, W. (2019). Water accounting to assess climate change impact on water resources for agriculture. FutureWater, Spain. <https://www.imprex.eu/index.php/system/files/generated/files/res ource/d11-5-imprex-wa-v1-0.docx> [Consulta: 01 de junio de 2020]. 


\section{RESULTADOS Y DISCUSIÓN}

En esta sección se aportan los principales resultados de la tesis doctoral, motivando y discutiendo todas las decisiones tomadas para desarrollar y adaptar al caso de estudio las metodologías propuestas, ya sea referentes a aplicaciones cuantitativas y cualitativas a largo plazo (cambio climático), o a medio plazo, como las metodologías integradoras de pronósticos estacionales de P y $\mathrm{T}$.

\subsection{Metodología para la integración de proyecciones climáticas}

En este apartado, se introducen los resultados más relevantes de la metodología desarrollada para la integración de proyecciones climáticas en la toma de decisiones y su aplicación al caso de estudio (secciones 2.1, 2.2 y 2.3), además de motivar cada decisión tomada durante este proceso, como explicamos a continuación.

A pesar de que la metodología presentada en los puntos $2.1,2.2$ y 2.3 podría ser mucho más fácil si se partiera directamente de proyecciones hidrológicas (caudales) disponibles en servicios climáticos, al analizar las del SMHI con su modelo E-HYPE (Hundecha et al., 2016) se observó que en los meses de verano (sobre todo julio y agosto) estas eran nulas $\left(0 \mathrm{~m}^{3} / \mathrm{s}\right)$ en todos los miembros del ensamblado y subcuencas estudiadas (Fig. 14). Esto se debe a que este modelo, como otros modelos hidrológicos paneuropeos, no mantiene las características de las series en régimen natural por diversos motivos, como la incorporación de cierto tipo de regulación en su modelación, una deficiente consideración de los acuíferos y la calibración con series de caudales observados en lugar de en régimen natural, entre otros.

Por lo tanto, al tener estos valores nulos, que son muy difíciles de corregir por no decir imposible, se decidió iniciar nuestro propio proceso con las variables meteorológicas (de P y T) y utilizar el modelo hidrológico 
de la cuenca del Júcar (propiamente calibrado) para obtener las aportaciones con las que posteriormente se simulará la gestión del sistema.

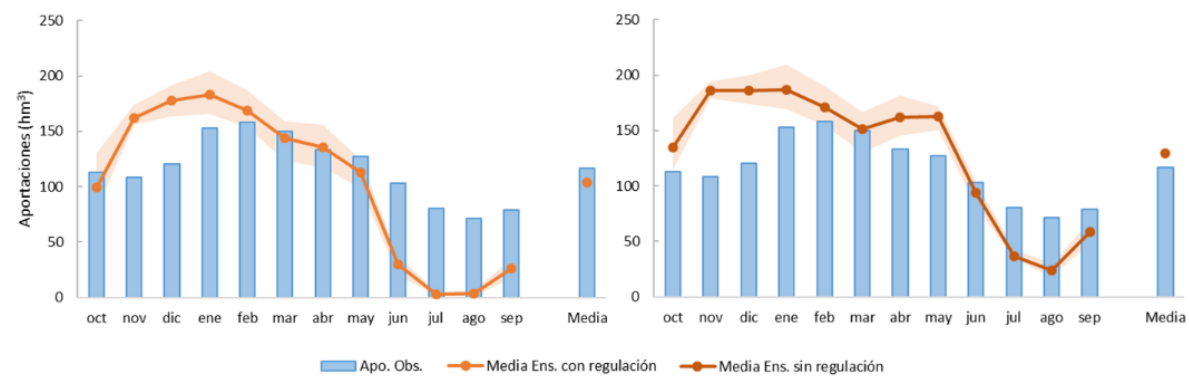

Fig. 14. Comparativa del ensamblado (zona sombreada) de aportaciones climáticas (con y sin regulación) y las aportaciones observadas en el año medio del periodo 1971-2000 en la cuenca del Júcar.

Hay que decir que, en paralelo, y ante las demandas de los usuarios finales de las proyecciones de caudales del proyecto SWICCA, entre los que se encontraba el GIRH-UPV, el SMHI proporcionó datos de caudales sin regulación, lo que aumentó el valor de los caudales en verano. Sin embargo, estas aportaciones también necesitaban de una corrección del sesgo, ya que, como se muestra en la Fig. 14, sobrestiman las aportaciones históricas en los meses de otoño y primavera y siguen subestimándolas en los meses de verano, por lo que nos seguimos decantando por no utilizarlas.

Como hemos mencionado anteriormente, este comportamiento puede deberse a que los modelos a escala europea, como el E-HYPE, no tienen en cuenta o subestiman la influencia del componente subterráneo en la estación seca, que es de vital importancia en los meses de verano (junio a septiembre) en la cuenca del Júcar, ya que los caudales circulantes en régimen natural se deben principalmente a esta conexión con el acuífero (Suárez-Almiñana et al., 2020b, 2017). Por otra parte, es muy complicado captar todas las características de la cuenca en cuestión trabajando a tan gran escala. 
Además, algunos autores indican que podría no ser aconsejable trabajar con proyecciones hidrológicas debido a su baja capacidad predictiva, sobre todo en la zona Mediterránea (Donnelly et al., 2016). Teutschbein y Seibert, (2012) indican que los caudales procedentes de los MCR no suelen coincidir con los observados y que quizás no sean adecuados para ser usados directamente en la evaluación de los impactos hidrológicos a escala de subcuenca.

Por lo tanto, para evitar todos estos inconvenientes de las proyecciones hidrológicas, tanto en la adaptación de la metodología a este caso de estudio como a otras cuencas con similares características, seguimos con el plan inicial de utilizar nuestro propio modelo hidrológico con proyecciones meteorológicas como punto de inicio.

Una vez clarificado este aspecto, en el caso del Júcar vimos conveniente reducir el periodo de referencia (inicialmente 1971-2000) para tener en cuenta el efecto 80 y en todo caso no extender el exceso de recursos (provenientes de los años anteriores a 1980) a los periodos futuros mediante la corrección del sesgo. Al trabajar y corregir con el periodo inicial en Suárez-Almiñana et al., (2017), se obtuvieron resultados más optimistas de lo esperado para el horizonte 2039, lo que llevó a la conclusión de que quizás los impactos del cambio climático pronosticados para el futuro ya se estarían dando en esta cuenca desde la década de los 80 y los MCR no son capaces de captarlo.

Por lo tanto, se propuso reducir el periodo de referencia a 1980-2000, ya que este periodo es casi equivalente en recursos hídricos al de la serie corta 1980-2012 (Fig. 15) (Suárez-Almiñana et al., 2020a) y por lo tanto representa mejor la situación actual de la cuenca (CHJ, 2015).

En la Fig. 15 se puede observar esta equivalencia entre ambos periodos, así como la diferencia entre las medias anuales de la serie larga y la corta (efecto 80 ) del SEJ, estimada en un $21 \%$. El periodo proporcionado por las proyecciones climáticas también excede en gran medida los de la serie 
corta, cuantificada en un 14\%, siendo el periodo propuesto (1980-2000) el más adecuado para empezar el proceso y establecer la corrección del sesgo si fuera necesario.

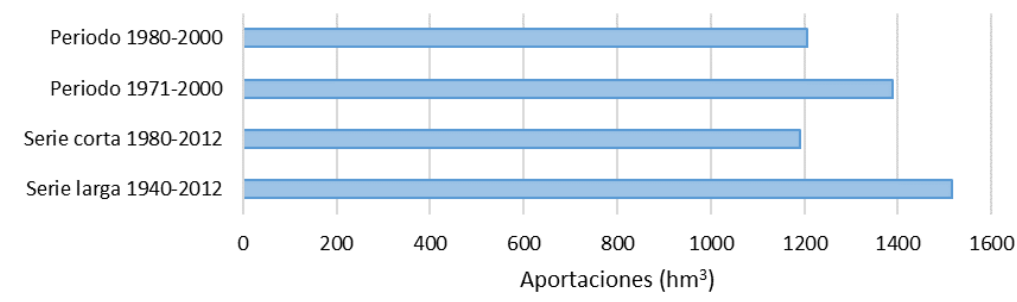

Fig. 15. Aportaciones medias anuales de los periodos históricos 1980-2000 (periodo de referencia propuesto), 1971-2000 (periodo de referencia climático), 1980-2012 (serie corta) y 1940-2012 (serie larga). Modificado de Suárez-Almiñana et al. (2020a).

Una vez tomada la decisión de ajustar el periodo de referencia al estado actual de la cuenca, se procedió a analizar las series de $\mathrm{P}$ y $\mathrm{T}$ de las proyecciones climáticas comparándolas con los datos observados (Spain02_v4). Mientras que las series de $P$ presentaron subestimaciones en la mayoría de las subcuencas (Fig. 16, Media Ens. P), las de T se encontraban sobrestimadas. Ante la disyuntiva de corregir o no el sesgo de estas series, se estimaron las aportaciones del periodo de referencia a partir de estos datos ( $P$ Y T) utilizando el modelo HBV para el SEJ (HBV-SEJ). En la Fig. 16, donde se comparan estas aportaciones (HBV-SEJ Media Ens.) con las observadas, se muestra cómo se encuentran subestimadas en la mayoría de las cuencas, sobre todo en las de cabecera, Alarcón y Contreras.

La subestimación en estas cuencas, donde se encuentra la mayor capacidad de embalse del sistema, no es aceptable para continuar con el proceso, ya que la situación presentada dista mucho del escenario real y en el caso de que esta subestimación sistemática también se encuentre en los periodos futuros, puede llevar a conclusiones muy preocupantes y erróneas sobre el efecto del cambio climático en los futuros recursos del sistema. 

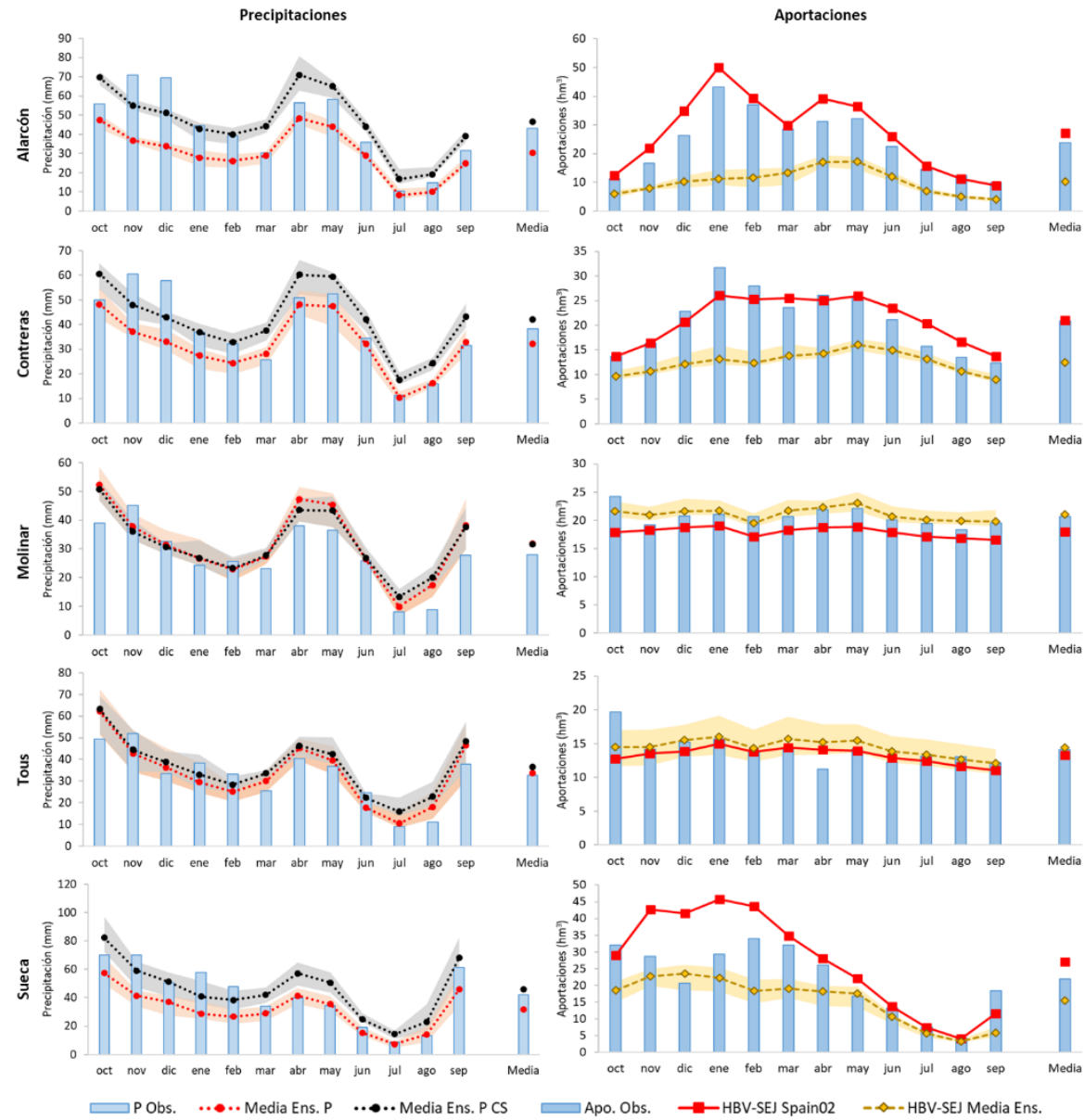

Fig. 16. Izquierda: comparativa entre los datos observados de $P$ con los datos de origen climático (Media Ens. P) y su corrección del sesgo (Media Ens. P CS). Derecha: comparativa entre las aportaciones observadas y las obtenidas con el modelo HBV-SEJ procedentes de las variables meteorológicas sin corregir (HBV-SEJ Media Ens.) y los resultados de calibración de este modelo (HBV-SEJ Spain02). Ambos para el año medio del periodo de referencia 19802000 por subcuenca. Modificado de Suárez-Almiñana et al. (2020b).

Ante esta subestimación, también se podría pensar que el modelo HBV no se encuentra calibrado correctamente, ya que la calibración en este tipo de sistemas es complicada, sobre todo por la interacción entre los componentes superficiales y subterráneos. Sin embargo, este no es el caso, ya que este modelo fue calibrado estrictamente para esta cuenca 
obteniendo buenos resultados (García-Romero et al., 2019), como se ha comentado en las secciones 2.2 y 2.3. Su calibración se muestra en la Fig. 16 (HBV-SEJ Sapain02), donde las cuencas de cabecera son las que presentan mejores resultados (Alarcón y Contreras), lo que desde el punto de vista de la gestión de los recursos hídricos es una ventaja importante ya que es donde se encuentran los embalses con mayor capacidad del sistema.

Por otro lado, existe un desajuste en la subcuenca de Sueca, que no es relevante para los objetivos de este estudio debido a que esta subcuenca se encuentra en el último tramo del río donde no existe regulación o es testimonial.

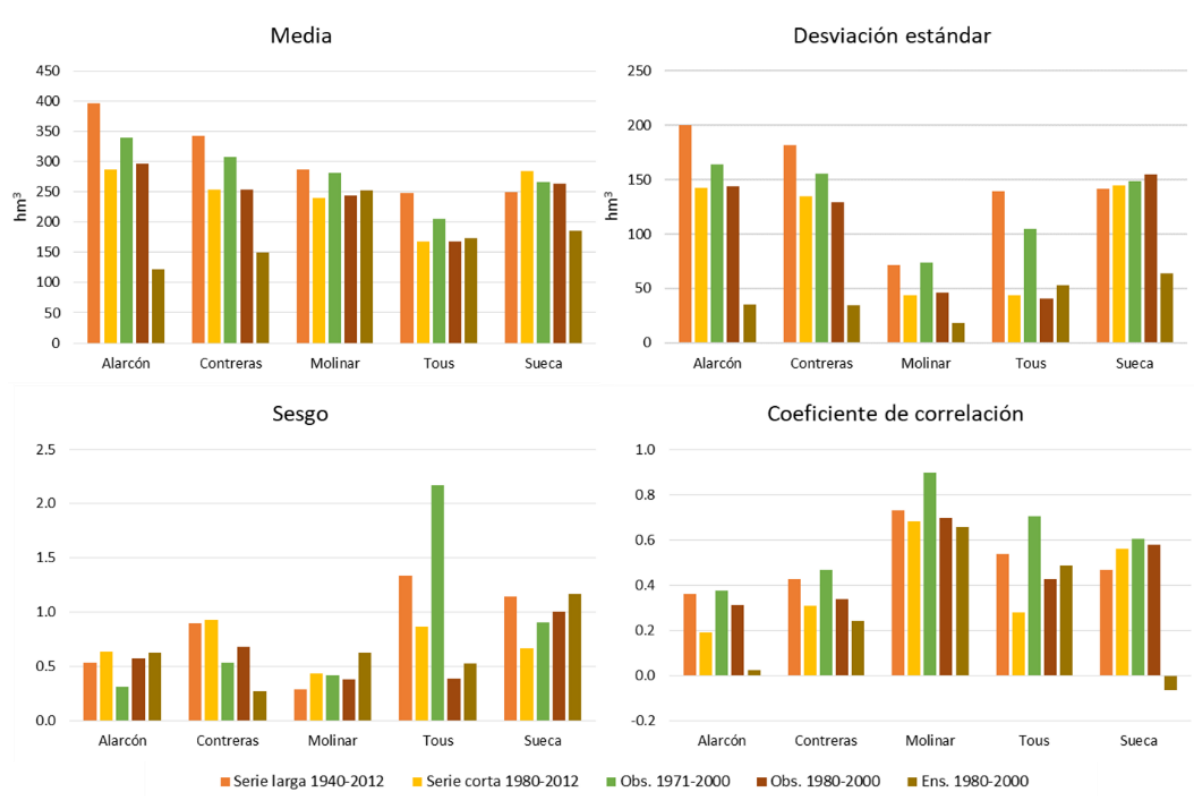

Fig. 17. Estadísticos básicos de las series de aportaciones observadas para la serie larga 1980-2012, la serie corta $1980-2012$, y los periodos $1971-2000$ y 1980-2000, además de los de las aportaciones del ensamblado 1980-2000 extraídas con el modelo HBV-SEJ.

La Fig. 17 muestra los estadísticos básicos de las series de aportaciones observadas nombradas hasta ahora (serie larga, serie corta, periodos de referencia) y de las del ensamblado del periodo de referencia propuesto 
1980-2000 (correspondiente con la Fig. 13). En ella se puede observar cómo la media y la variabilidad del ensamblado presenta valores muy bajos respecto de la serie observada del mismo periodo 1980-2000. Esto también puede ser debido a que se trabaja con la media del ensamblado, aunque como se puede observar en la Fig. 16, el rango cubierto por todos los miembros del ensamblado no es muy amplio. Sin embargo, los valores de la serie corta y la del periodo de referencia propuesto son muy similares en todas las cuencas, lo que refuerza la elección de este periodo como punto de inicio.

En cuanto al sesgo, es positivo y todas ellas tienen valores similares, exceptuando las series larga y la de 1971-2000 en Tous, que son más elevados. Mientras la correlación de las series es positiva y con valores similares en general, exceptuando la serie corta con valores más bajos y la del periodo 1971-2000 con valores más elevados, en el caso del ensamblado estos valores son muy bajos en Alarcón y Contreras, incluso negativa en Sueca.

Por lo tanto, teniendo en cuenta todos estos aspectos, se hace necesaria una corrección de sesgo, ya sea de las variables meteorológicas (opción A sección 2.3) o de las aportaciones (opción B sección 2.3). En este caso, se probaron ambas alternativas aplicando la técnica del mapeo de cuantiles, una técnica muy apreciada y extendida por su facilidad de manejo y buenos resultados (Grillakis et al., 2017; Manne et al., 2017; Teutschbein y Seibert, 2012). Con ella se pretende reproducir la media y la desviación estándar de la serie observada (Collados-Lara et al., 2018) y posteriormente extender esta corrección a los horizontes futuros. 

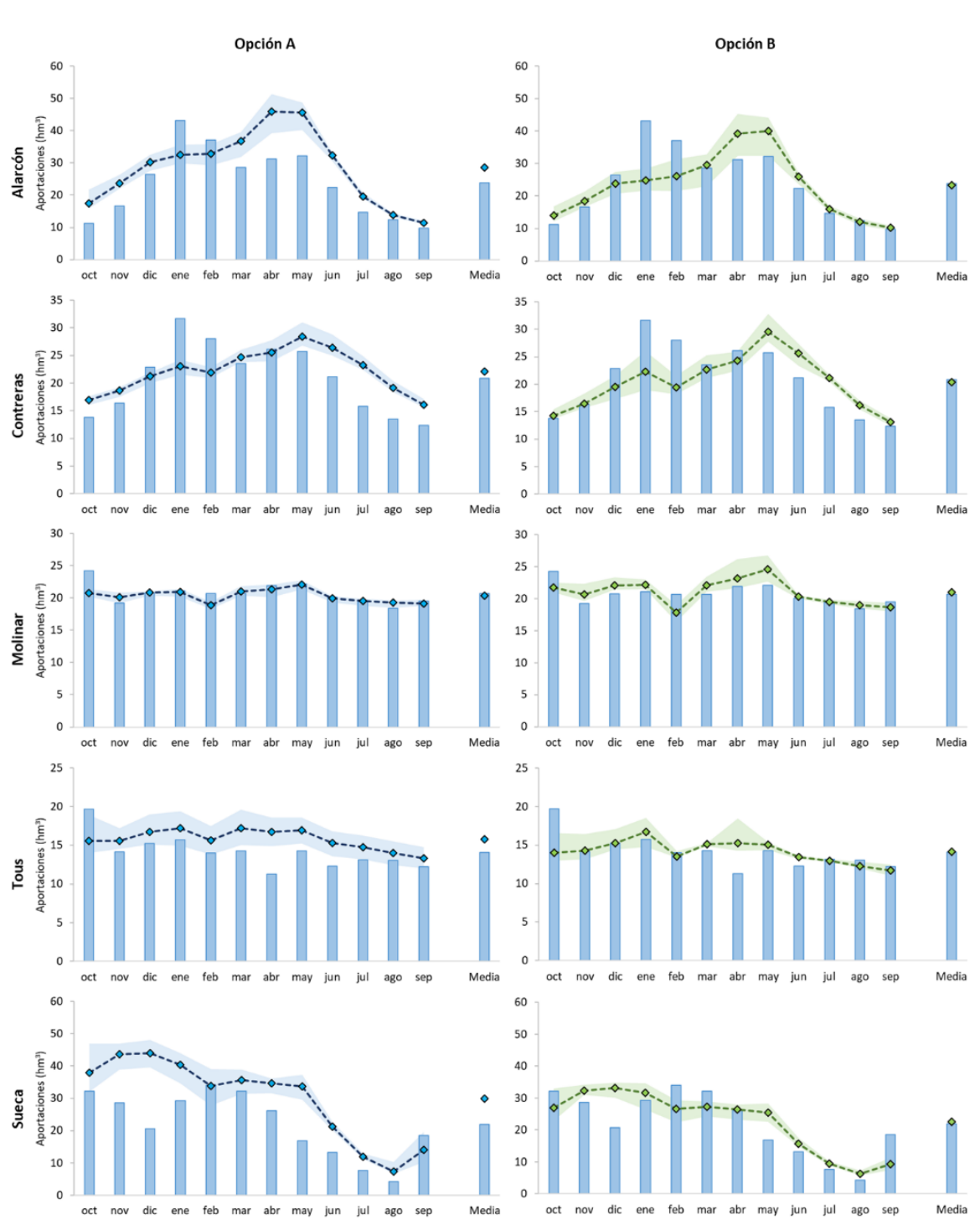

$\square$ Apo. Obs. $\quad-\nsim-$ HBV-SEJ Media Ens. A $\quad-\diamond-$ HBV-SEJ Media Ens.B

Fig. 18. Comparativa entre las aportaciones observadas (Apo. Obs.) del periodo de referencia 1980-2000 y los ensamblados extraídos del modelo HBV-SEJ en las opciones A (HBV-SEJ Media Ens. A) y B (HBV-SEJ Media Ens. B), ya corregidos en esta última opción. Modificado de Suárez-Almiñana et al. (2020b).

La Fig. 18 muestra el resultado de estas correcciones (opciones A y B) en las aportaciones del periodo de referencia. Los resultados de ambas 
alternativas de corrección son similares, sin embargo la opción A tiende a sobreestimar en mayor medida a las aportaciones observadas, sobre todo en los meses de primavera y principios de verano en las subcuencas de cabecera. En estas subcuencas, también se subestiman las aportaciones en los meses de enero y febrero (ambas opciones). En el caso de la opción A, estas sobrestimaciones primaverales y subestimaciones invernales pueden provenir de la corrección del sesgo de las $\mathrm{P}$, como se muestra en la Fig. 16 (Media Ens. P CS).

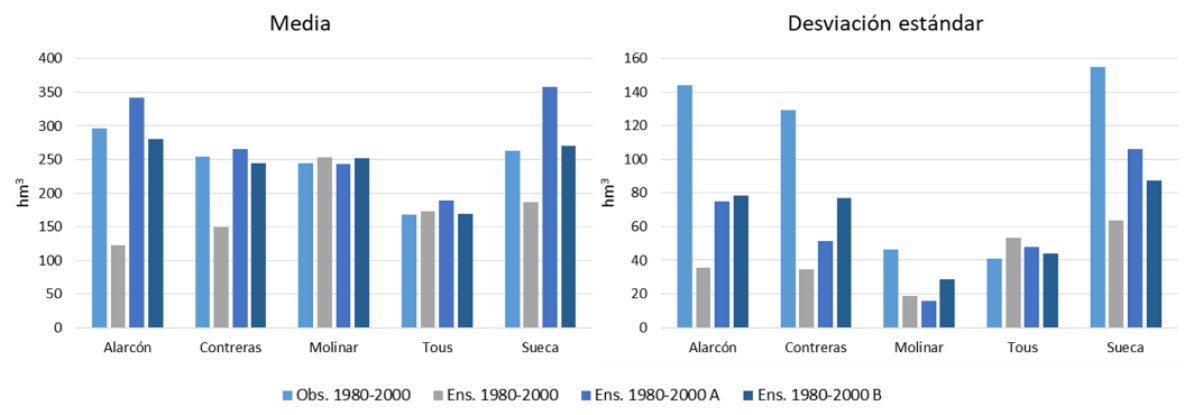

Fig. 19. Media y desviación estándar del periodo de referencia 1980-2000 en la serie observada (Obs. 1980-2000), la serie del ensamblado sin corregir (Ens. 1980-2000) y la del ensamblado corregido en las opciones A (Ens. 1980-2000 A) y B (Ens. 1980-2000 B).

En cuanto a la media, la opción B consigue una mejor aproximación, mientras que la opción A tiende a sobreestimarla, sobre todo en Sueca. Este hecho también se puede observar en la Fig. 19, donde se muestra cómo se han conservado las principales características estadísticas de la serie observada en el ensamblado de ambas opciones. A pesar de que ambas opciones se acercan a la media observada, sobre todo la B como hemos dicho anteriormente, en el caso de la desviación estándar no ocurre lo mismo en la mayoría de las cuencas, ya que su valor era muy bajo en el ensamblado sin corregir (Ens. 1980-200).

A pesar de estos desajustes con la serie observada, ambas correcciones se consideraron satisfactorias y se procedió con la corrección de los periodos futuros para seguir con el proceso. 

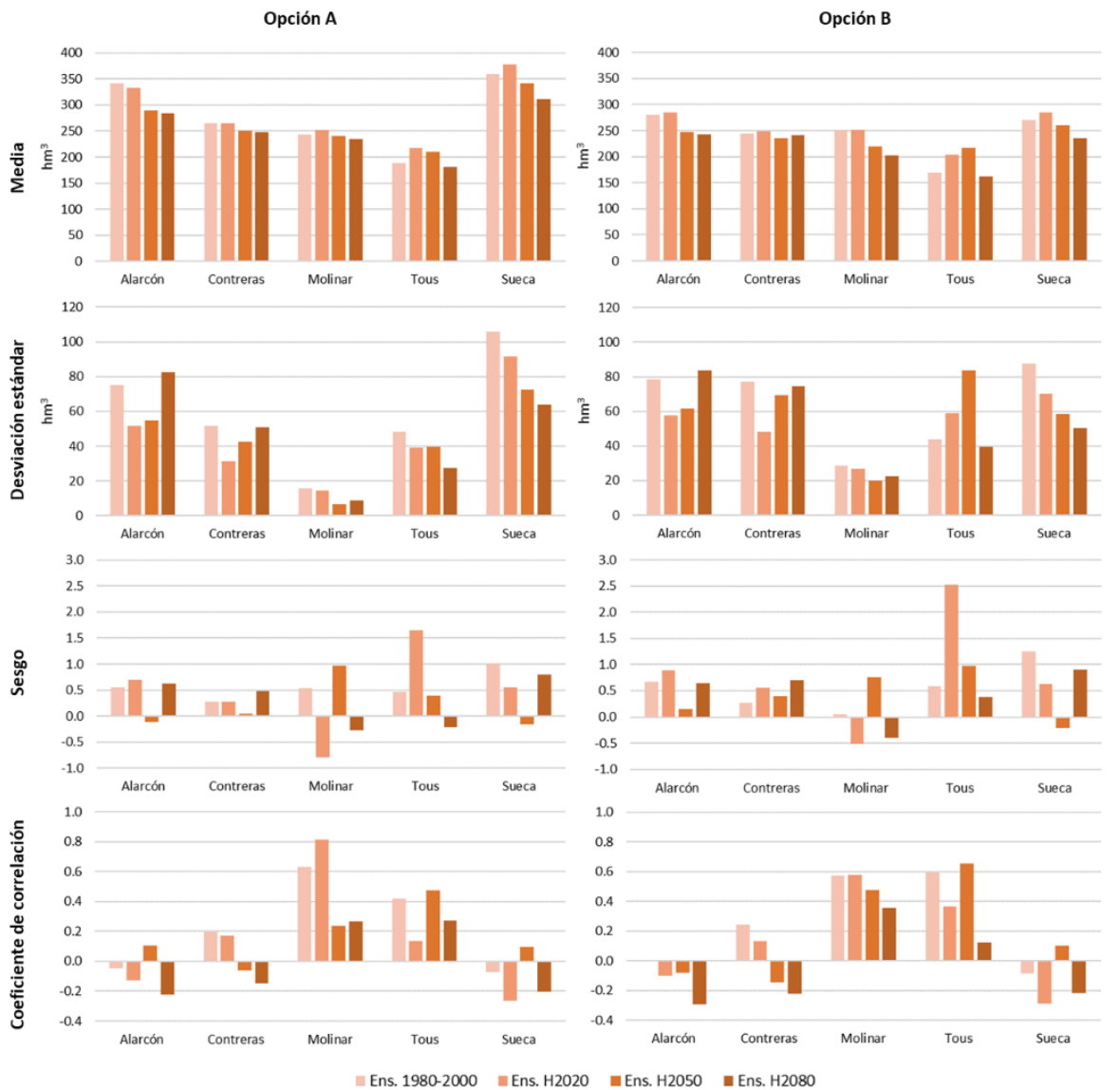

Fig. 20. Estadísticos básicos de los ensamblados del periodo de referencia 1980-200 y de los horizontes 2020, 2050 y 2080 en ambas opciones metodológicas (A y B).

En ambas opciones, se observa una tendencia descendiente de las aportaciones futuras, sobre todo en el horizonte 2080. La Fig. 20 muestra mayores reducciones de la media de cada horizonte en la opción $B$, aunque la diferencia no es muy elevada. A pesar de esto, la media del horizonte 2020 sobrepasa a la del periodo de referencia en algunas subcuencas, sobre todo en Tous, también sobrepasado en el horizonte 2050. En cuanto a la desviación estándar, sus valores se incrementan en los horizontes futuros en algunas subcuencas, lo que puede ser debido a la mayor dispersión de los miembros del ensamblado. 


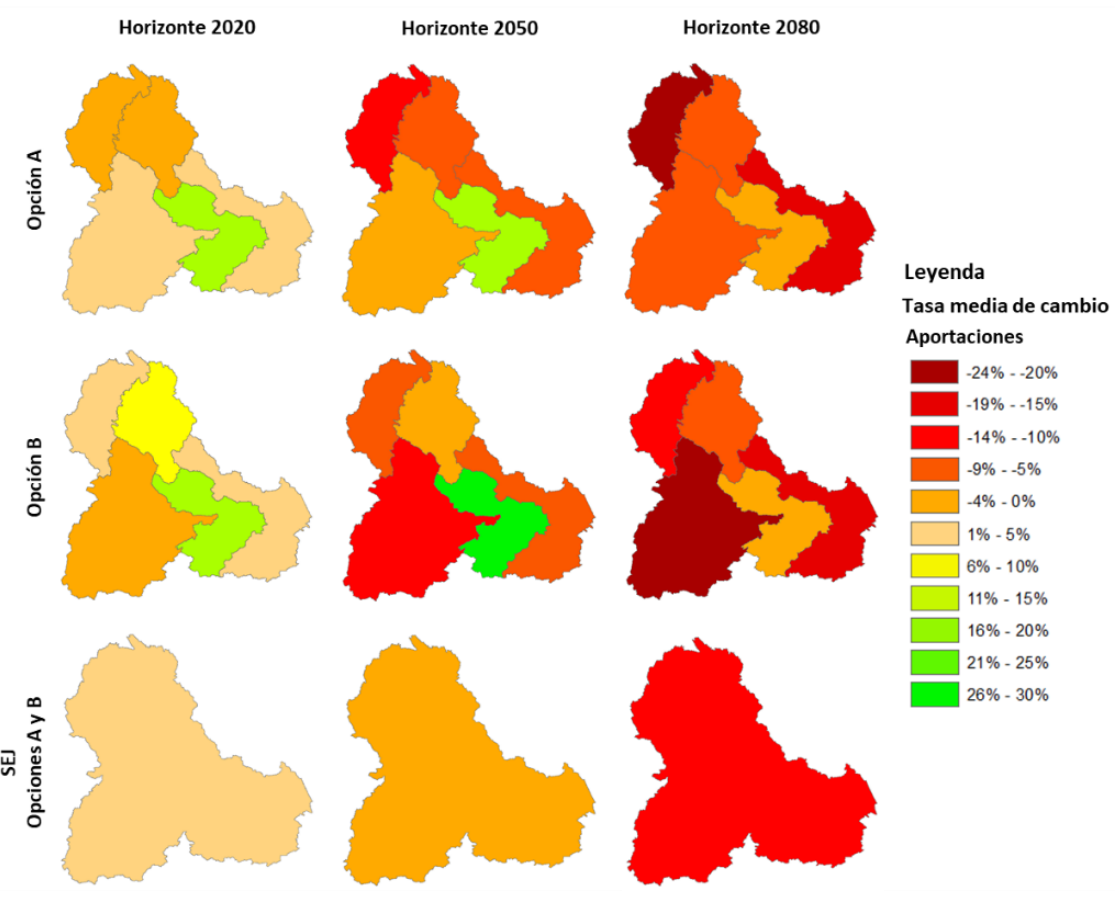

Fig. 21. Tasa media de cambio d las aportaciones futuras por horizonte (2020, 250 y 2080), opción metodológica ( $\mathrm{A}$ ○ B) y subcuenca, además de para el SEJ teniendo en cuenta ambas opciones. Modificado de Suárez-Almiñana et al. (2020b).

Una vez obtenidas todas las aportaciones, se extraen sus tasas medias de cambio futuras por subcuenca, horizonte y opción metodológica. En la Fig. 21 se muestra como, en general, estas tasas se reducen conforme nos acercamos a finales de siglo, coincidiendo con otros estudios de la zona (Barranco et al., 2018; CEDEX, 2017; Marcos-Garcia y Pulido-Velazquez, 2017). Sin embargo, estas reducciones son preocupantes en las cuencas de cabecera, ya que es donde se encuentra la mayor capacidad de embalse del sistema y puede significar menores recursos disponibles para el sistema en el futuro.

Además, las reducciones de la subcuenca de Molinar, sobre todo en la opción B, podría significar una menor infiltración al acuífero de La Mancha Oriental, por lo que esta situación también puede llevar a una mayor sobreexplotación de los recursos subterráneos para hacer frente a las 
demandas de riego agrícolas. Estas demandas también se pueden ver incrementadas en la zona costera, ya que en esta zona también se prevén importantes reducciones de aportaciones. En todo caso, son escenarios insostenibles y un gran reto para los gestores de cuenca a la hora de gestionar un sistema con recursos cada vez más mermados.

A pesar de esto, llama la atención el caso de Tous, con incrementos significantes, posiblemente debido a la conexión que tiene esta cuenca con el componente subterráneo (modelado con el HBV-SEJ) y el incremento de precipitaciones que se ha observado en los últimos años en esta zona (Hernández Bedolla et al., 2019), que parece ser captado por los MCR y podría seguir hasta el horizonte 2050. De todas formas, la variabilidad de estas tasas entre subcuencas no es un caso aislado (Folton et al., 2019).

En este caso, para toda la cuenca se estiman unas tasas medias de cambio de las aportaciones futuras del 3\% para el horizonte 2020 , -3\% para el 2050 y de $-12 \%$ para el 2080, siendo estas la media de ambas opciones. Estas tasas de reducción pueden parecer muy pequeñas si tenemos en cuenta otros trabajos oficiales en esta zona, como el Informe del CEDEX (2017), donde se evalúa el impacto del cambio climático en los recursos hídricos y sequías de España. En este trabajo, se estiman tasas medias de $7 \%,-18 \%$ y -28 (SRC 4.5 y 8.5 ) para toda la $\mathrm{DHJ}$, aplicables a cualquier punto de la demarcación (Barranco et al., 2018). Las principales diferencias entre ambas tasas de cambio se deben a que en el trabajo del CEDEX no se ha corregido el sesgo de las variables meteorológicas, a pesar de encontrar las P subestimadas (Barranco et al., 2018), y al hecho de trabajar con el periodo de referencia 1960-2000. Este periodo, como el de 1971-2000, considera mayor cantidad de recursos, que al ser comparados con los periodos futuros arroja porcentajes de reducción más elevados.

De hecho, dependiendo de con qué periodo histórico se comparen los periodos futuros se pueden obtener conclusiones más o menos alarmantes. Además, no existe ninguna regla que indique el origen (observado o simulado) de las series que se han de tomar como referencia para la 
extracción de estas tasas de cambio. En nuestro caso, elegimos un periodo que representara la situación actual de la cuenca (teniendo en cuenta la disponibilidad de datos) y cuyo origen es el mismo que el de los periodos futuros, ya que ambos proceden de las proyecciones climáticas.

Sin embargo, en la Fig. 22 se puede observar como estos porcentajes pueden cambiar dependiendo de la serie de referencia escogida. En este caso se tuvieron en cuenta cuatro periodos y tres orígenes diferentes para toda la cuenca: serie larga (1940-2012), serie corta (1980-2012), periodo de referencia (1980-2000) y periodo de referencia descartado (1971-2000) de las series observadas, de los ensamblados y de las series simuladas con el modelo HBV-SEJ, iniciado con los datos observados de P y T (Spain02).

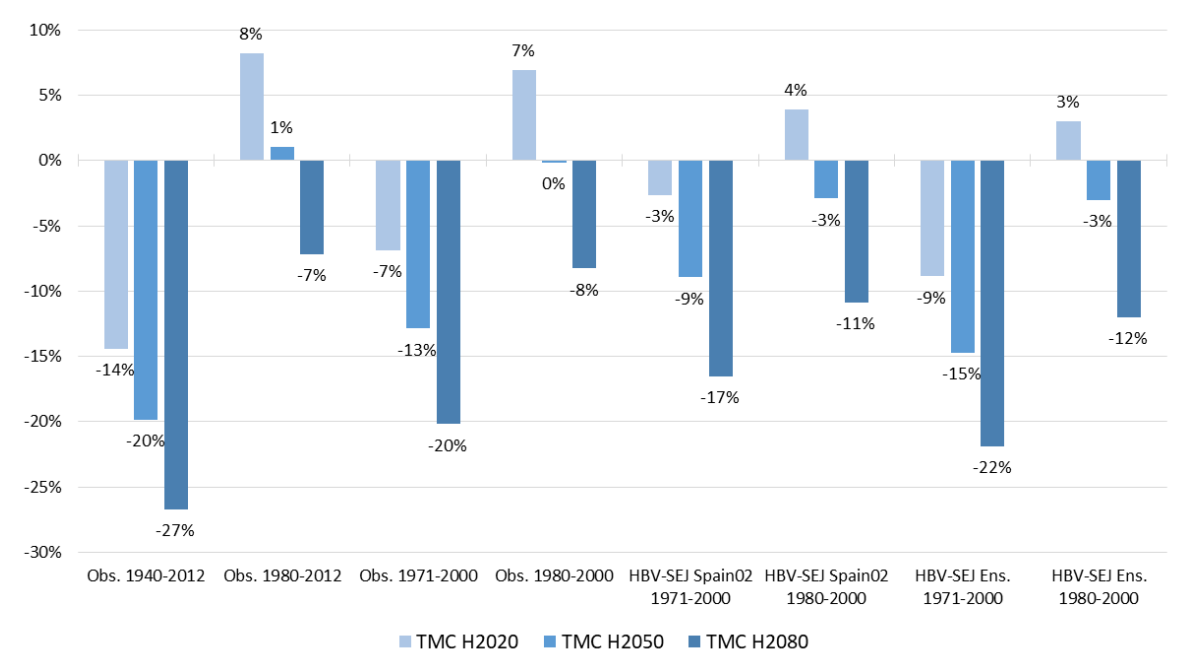

Fig. 22. Tasa media de cambio (TMC) de las aportaciones futuras (media de opciones A y B) dependiendo del periodo histórico y el origen de las series con el que se compare. Modificado y actualizado de Suárez-Almiñana et al. (2020a).

Si se hubiera trabajado con el periodo 1971-2000, se hubieran obtenido resultados muy similares a los del CEDEX, sobre todo con el ensamblado, que fue corregido con la serie observada de ese mismo periodo. Sin embargo, los resultados obtenidos con respecto a los periodos de la serie 
corta y el periodo de referencia son muy similares, dejando el caso más extremo para la serie larga, con -27\% para el horizonte 2080.

Estos resultados nos hacen ser conscientes de la gran incertidumbre que se puede introducir en el proceso al manejar este tipo de proyecciones, por lo que es esencial hacer constancia del periodo de referencia utilizado y su origen cuando se presentan estas tasas, con el fin de evitar malentendidos y conclusiones erróneas, que pueden ser más o menos alarmistas. De todas formas, sea cual sea la reducción estimada en esta cuenca, todas ellas plantean escenarios futuros muy difíciles de gestionar e incluso insostenibles teniendo en cuenta las demandas actuales del sistema, ya que actualmente la relación entre las demandas y los recursos es del $90 \%$, siendo el Júcar un sistema estresado.

Seguidamente, para conocer el volumen de recursos hídricos del que dispondremos en el futuro, se simula el modelo de gestión con los ensamblados de las aportaciones futuras (periodo 2011-2098) provenientes de ambas opciones.

En la Fig. 23 puede verse el volumen almacenado en el conjunto de los tres embalses más importantes del sistema, Alarcón, Contreras y Tous (capacidad total $1.796 \mathrm{hm}^{3}$ ). En la opción A, tanto la media del ensamblado como la media de cada horizonte futuro muestra valores más elevados que la opción B, algo lógico si tenemos en cuenta los resultados anteriores. Por otra parte, el área de frecuencia del ensamblado (zona más clara) muestra que la mayoría de los miembros del ensamblado de la opción A coinciden en volúmenes elevados mostrando un par de episodios críticos (volúmenes muy bajos) por horizonte, mientras que en la opción B se observan cada vez más periodos críticos o de sequía a partir del horizonte 2050 .

Por lo tanto, el escenario planteado por la opción B es el más crítico y podría ser el más acertado, ya que los datos del periodo de referencia de la opción A sufrían más sobreestimaciones después de la corrección del sesgo. Además, la opción B también puede ser la opción más interesante desde el 
punto de vista de la gestión de los recursos al contemplar peores escenarios. Sin embargo, el ensamblado de ambas opciones ocupa prácticamente todo el volumen contemplado, sobre todo en la opción $\mathrm{B}$, lo que indica una gran dispersión de los miembros del ensamblado y una gran incertidumbre futura, siendo necesario un análisis probabilístico para complementar este enfoque. De este modo, los resultados podrían aportar un mayor grado de fiabilidad para los tomadores de decisiones.

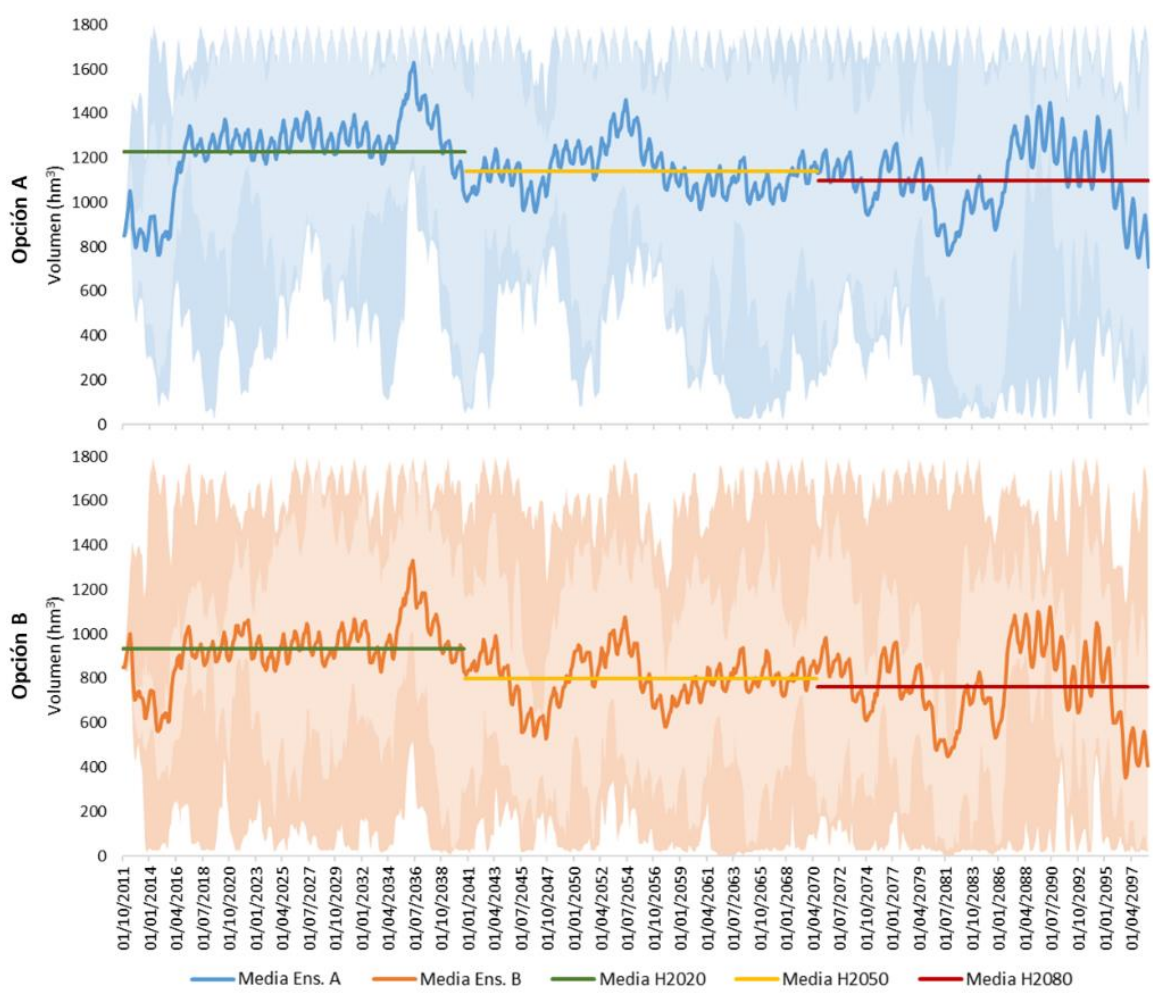

Fig. 23. Recursos hídricos almacenados en el conjunto Alarcón-Contreras-Tous durante el periodo futuro 2011-2098, donde se muestra la variabilidad del ensamblado y su media en cada opción metodológica y la media de cada horizonte. Modificado de: Suárez-Almiñana et al. (2020b).

En la Fig. 24 se puede observar un indicador de riesgo de sequía para la media del ensamblado por opción y horizonte futuro. Este indicador, que es resultado de la simulación de las múltiples series generadas en el modelo 
estocástico y el tratamiento estadístico del modelo de análisis de riesgo, informa de la evolución probabilística de los recursos almacenados en el sistema en el año medio de cada horizonte. Para ello, la capacidad total del sistema $\left(1.796 \mathrm{hm}^{3}\right)$ se dividió en 10 intervalos iguales que son expresados en porcentaje de volumen ocupado. La elección de este indicador se debe a la gran influencia que tienen los volúmenes embalsados del sistema en el IEE del PES, un 50\% (Haro-Monteagudo et al., 2017). Por lo tanto, con el uso de este indicador se pretende aproximarse al IEE e incluso complementarlo.
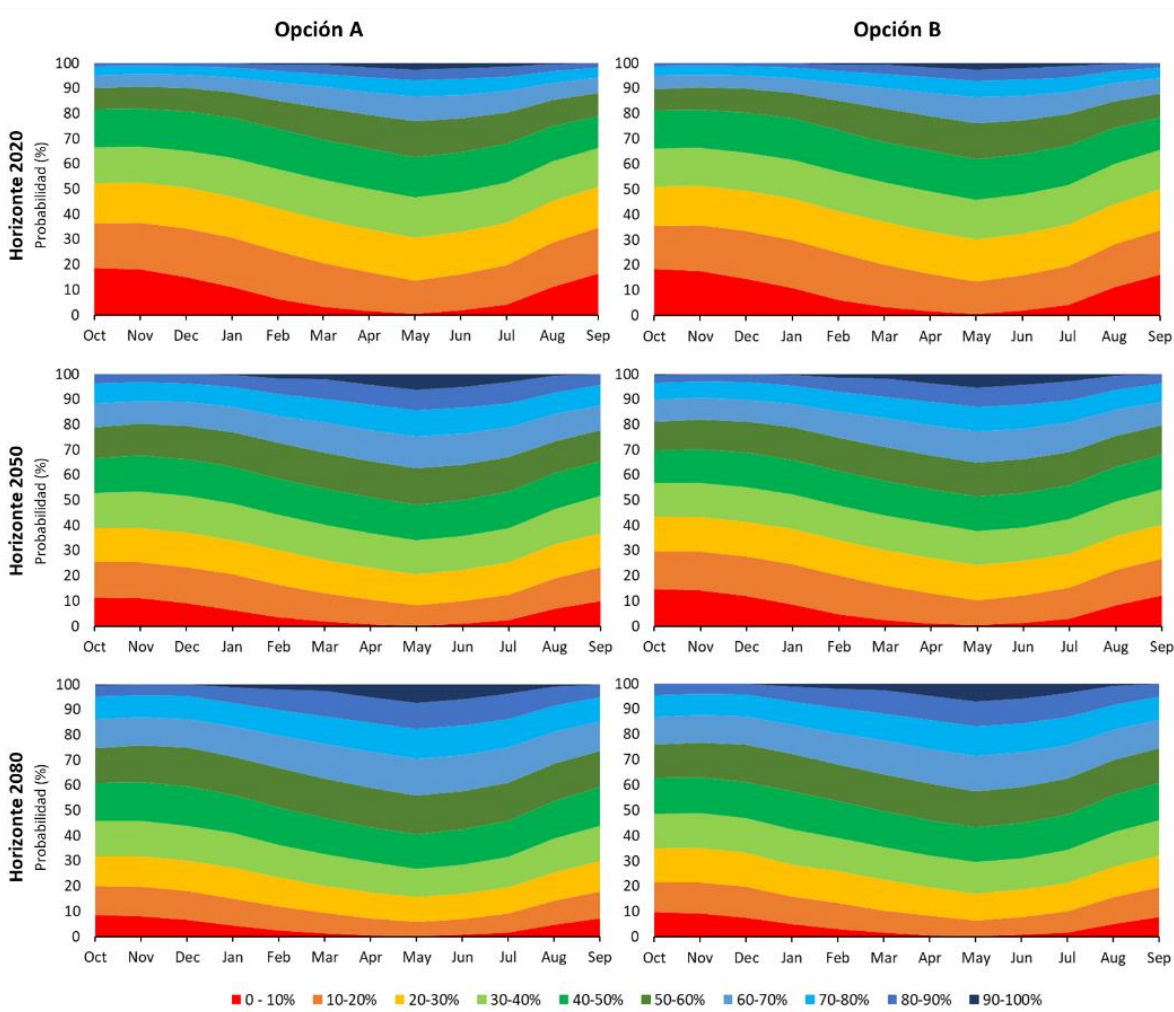

Fig. 24. Indicador del riesgo de sequía de la media del ensamblado para los horizontes 2020, 2050 y 2080 en las opciones metodológicas A y B. Modificado de: Suárez-Almiñana et al. (2020b).

Las probabilidades de almacenamiento en el sistema de ambas opciones son muy similares en todos los horizontes, aunque un poco más elevadas 
en la opción B. En el futuro cercano, existe alrededor de un $80 \%$ de probabilidades de que el sistema se encuentre por debajo del $50 \%$ de su capacidad total (898 $\mathrm{hm}^{3}$, verde intermedio). Sin embargo, las probabilidades de que el sistema se encuentre en este mismo intervalo son de alrededor del $70 \%$ y $60 \%$ en los horizontes 2050 y 2080, respectivamente. Estos resultados pueden llevar a la conclusión equivocada de que las probabilidades de encontrar cada vez menos recursos hídricos en el sistema van disminuyendo conforme nos acercamos a finales de siglo, justo lo contrario que hemos observado hasta ahora en los resultados de las tasas medias de cambio (Fig. 22 y 23) y en el enfoque determinista (Fig. 23).

Esto es debido a que a partir del horizonte 2050 las probabilidades de caer en cualquier intervalo volumétrico son cada vez más parecidas, hasta llegar al $\approx 10 \%$ que se observa en el horizonte 2080 , lo que concuerda con el amplio rango cubierto por el ensamblado de la Fig. 23, indicando de nuevo que la variabilidad de los miembros del ensamblado es muy elevada a partir de mediados de siglo. Esta variabilidad provoca que sus resultados se compensan y que los indicadores de la media del ensamblado indiquen que cualquier cosa podría pasar en el futuro, es decir una gran incertidumbre futura. Lo mismo ocurre si se utiliza la media del ensamblado de cada SRC, con resultados un poco más pesimistas para la SRC 8.5 pero con la misma incertidumbre mostrada en la Fig. 24 a partir del horizonte 2050.

A la vista de estos resultados, también se consideró estudiar las probabilidades de excedencia de volumen almacenado en el mes de septiembre de cada horizonte, con el objetivo de estimar la situación final del sistema al cabo del año hidrológico, justo después de la estación de riego. En la Fig. 25 se puede observar como el rango del ensamblado para el futuro próximo rodea la media del ensamblado en ambas opciones, mientras que este rango se va ensanchando en el futuro medio y lejano, fruto de la variabilidad mencionada anteriormente. En general, las probabilidades de excedencia de volúmenes de almacenamiento más 
elevados son mayores en la opción A, coincidiendo con los resultados obtenidos en las Fig. 23 y 24.

En el futuro próximo, las probabilidades de excedencia parecen bastante claras $y$ ambas opciones coinciden en que hay un $34 \%$ de probabilidades de sobrepasar el $50 \%$ de la capacidad total del sistema $\left(898 \mathrm{hm}^{3}\right)$, disminuyendo progresivamente volúmenes mayores.
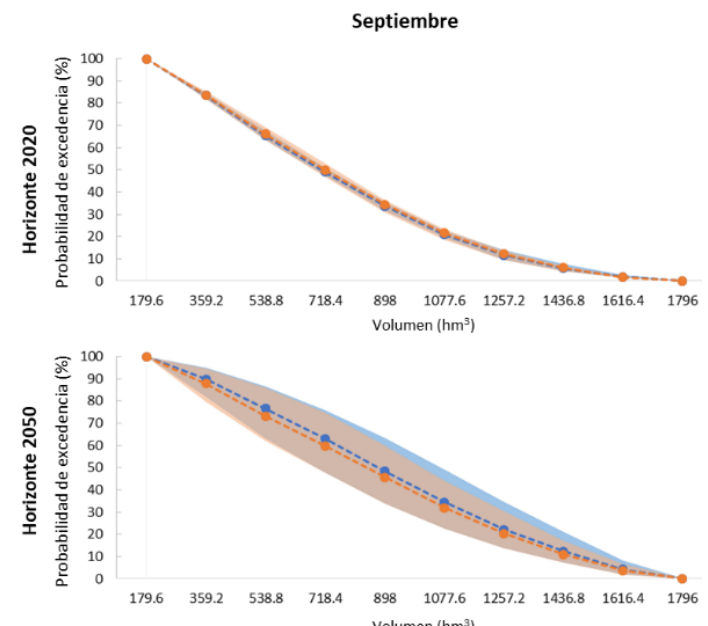

Sin embargo, las probabilidades de excedencia de la misma capacidad en el futuro medio son entre $34 \%$ $63 \%$ (ambas opciones), un rango bastante amplio que también se puede observar en el horizonte 2080, confirmando nuevamente la

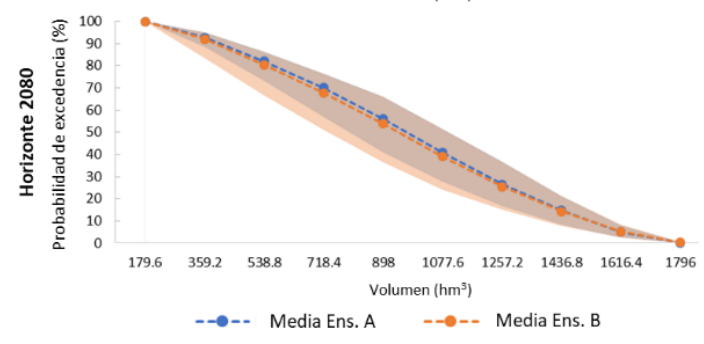

Fig. 25. Probabilidad de excedencia en septiembre para cada horizonte futuro y opción metodológica. Modificado de: Suárez-Almiñana et al. (2020b). gran incertidumbre a la que hacemos frente a partir del horizonte 2050.

A pesar de todos los esfuerzos efectuados en este estudio para adaptar la metodología a la cuenca del Júcar e intentar disminuir la incertidumbre asociada a los datos de cambio climático y al proceso en sí (basado en las características actuales del SEJ), los resultados del indicador no han resultado concluyentes para estimar el riesgo de sequía a partir de mediados de siglo. Esto indica que podría ser necesaria una mejora de las proyecciones climáticas para incluir estos datos de forma efectiva y confiable en el proceso de toma de decisiones a largo plazo. Sin embargo, la 
metodología propuesta es robusta y considera varios puntos clave que pueden ser problemáticos a la hora de seguir con el proceso, donde se han tomado decisiones acertadas que han resultado en una metodología general adaptable a otras cuencas.

Por lo tanto, es necesario seguir investigando en este aspecto, sobre todo en la mejora de la capacidad predictiva de los datos de cambio climático, ya que en ciertas zonas, como la Mediterránea, es muy baja (Barranco et al., 2018; Collados-Lara et al., 2018). Además, la incertidumbre inherente de los MCR y su dispersión es un tema recurrente a nivel global (Chatterjee et al., 2018; Stagl y Hattermann, 2016). Estos aspectos son los que más influyen en la fiabilidad de los resultados finales, lo que da lugar a que los gestores de cuenca no confíen en ellos para la toma de decisiones (Lemos y Rood, 2010).

Por otro lado, los post-procesos podrían resolver, en parte, este problema. Sin embargo, parece que el uso del mapeo de cuantiles, la técnica más extendida en la literatura (Collados-Lara et al., 2018; Grillakis et al., 2017; Manne et al., 2017; Teutschbein y Seibert, 2012), no ha sido suficiente en este caso. También, puede que las técnicas de corrección existentes no sean del todo satisfactorias, ya que según Ehret et al. (2012) no aportan una justificación física y parece que esconden la incertidumbre en vez de reducirla. En nuestro caso, una corrección estacional o centrada en los estadísticos de las sequias históricas podría ser beneficiosa, ya que la gestión de este sistema está centrada sobre todo en la estación de riesgo y parece que los MCR no son capaces de reproducir estos estadísticos (Collados-Lara et al., 2018; Cook et al., 2008; Seager et al., 2008).

Por último, hay que recalcar que las tendencias decrecientes de las aportaciones futuras y las altas probabilidades de encontrarnos con volúmenes de almacenamiento menores al $50 \%$ de la capacidad total del sistema son preocupantes, suponiendo un gran desafío para la gestión futura de este sistema de explotación. Por lo tanto, es necesario plantearse la revisión y adaptación de las reglas de operación, dotaciones y elementos 
relacionados del sistema para hacer frente a situaciones más intensas y duraderas de escasez hídrica en el futuro, además de la toma de medidas preventivas para evitar graves impactos ambientales y socioeconómicos derivados de estos escenarios tan insostenibles con las características actuales del sistema.

\subsubsection{Impacto del cambio climático en la calidad del agua}

En este apartado se relaciona el impacto del cambio climático en las aportaciones futuras (evaluado en la sección anterior) con el estado cualitativo de las masas de agua en la cuenca del Júcar y su posible afección en el futuro siguiendo la metodología introducida en la sección 2.4 .

El primer paso fue asegurar la buena calibración del modelo al simular el periodo de referencia y obtener las afecciones de cada masa de agua mediante porcentajes de incumplimientos para cada contaminante. De esta simulación se obtuvo que la mayoría de las masas impactadas con incumplimientos mayores al $20 \%$ en todos los contaminantes se corresponden con las masas impactadas de la Fig. 5, siendo Molinar la subcuenca más afectada por todos los contaminantes y Sueca en el caso de los nitratos.

Seguidamente, fruto de la aplicación de las tasas medias de cambio de la opción B (sección 3.1) a las aportaciones históricas de cada masa de agua (periodo 1980-2010) y teniendo en cuenta a qué subcuenca pertenecen, se obtuvieron las aportaciones futuras con unas tasas de cambio medias para toda la cuenca del $6 \%$ para el horizonte $2020,-2 \%$ para el 2050 y $-12 \%$ para el 2080. Del mismo modo, se aplicaron tasas medias de cambio a la Ta histórica procedentes de las proyecciones climáticas de la Tabla 2 (SRC 4.5 y 8.5), previendo aumentos en la $T_{a}$ histórica de toda la cuenca $\left(14.8^{\circ} \mathrm{C}\right)$ de $0.9^{\circ} \mathrm{C}, 1.6^{\circ} \mathrm{C}$ y $2.4^{\circ} \mathrm{C}$ para los tres horizontes futuros. 


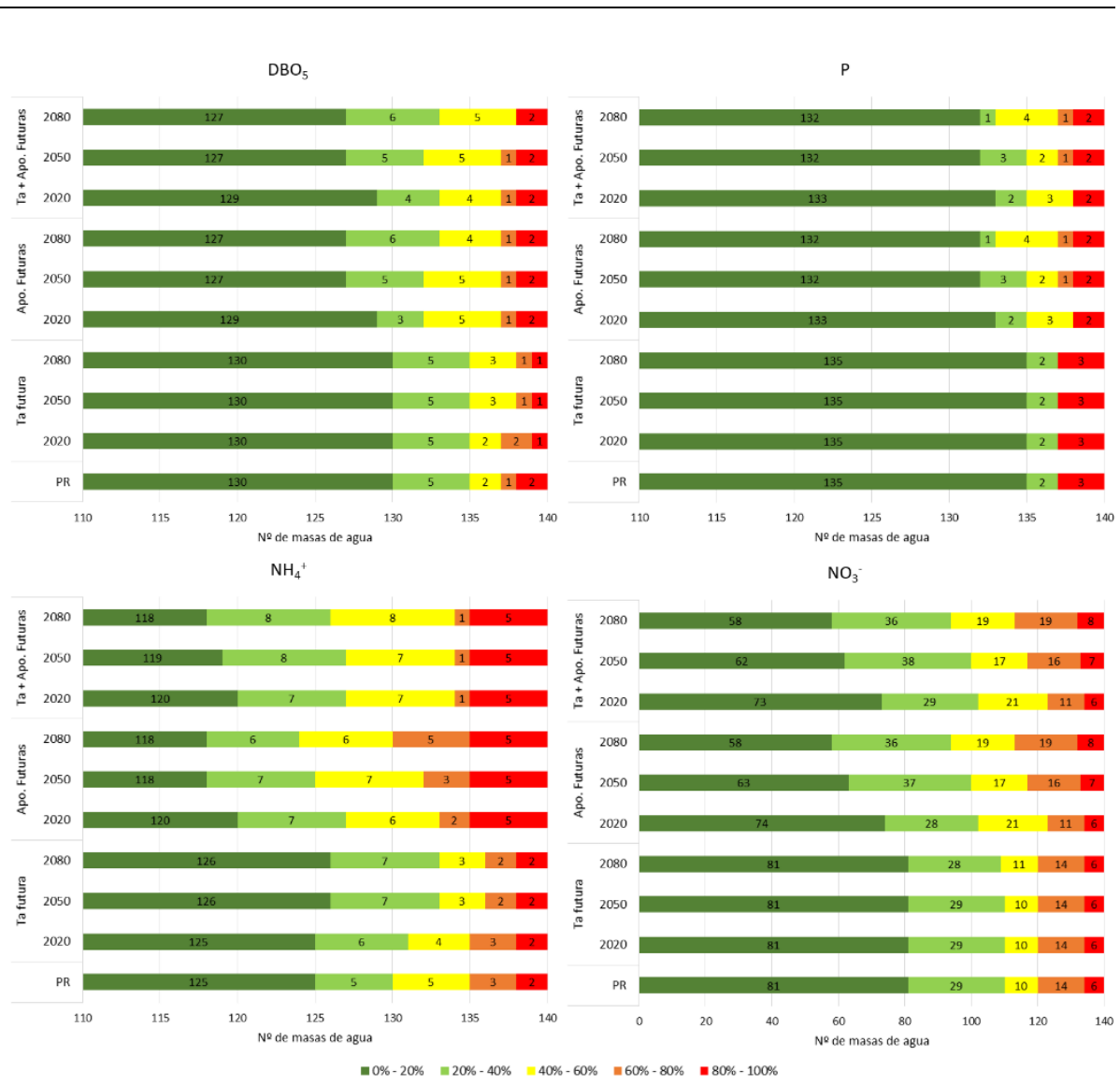

Fig. 26. Número de masas de agua en cada intervalo de incumplimiento por contaminante $\left(\mathrm{DBO}_{5}, \mathrm{P}, \mathrm{NH}_{4}{ }^{+}\right.$y $\left.\mathrm{NO}_{3}{ }^{-}\right)$, simulación (periodo de referencia - $\mathrm{PR}, \mathrm{T}_{\mathrm{a}}$ futura, Apo. Futuras o la combinación de ambas $-T_{a}+$ Apo. Futuras) y horizonte futuro (2020, 2050 y 2080). Fuente: Suárez-Almiñana et al., (2021).

Con estos datos se procedió a realizar las tres simulaciones futuras (sección 2.4). De este modo, en la Fig. 26 se puede ver cómo varía el número de masas pertenecientes a cada intervalo de incumplimiento dependiendo del contaminante, la simulación y el horizonte.

En el caso de la simulación con $T_{a}$ futura, los contaminantes que parecen estar más influenciados por esta variable son la $\mathrm{DBO}_{5}$ y el $\mathrm{NH}_{4}{ }^{+}$, sobre todo este último, con menores afecciones en los horizontes más lejanos, e indicando que a mayor $T_{a}$ se experimenta una mayor degradación (Serpa et 
al., 2017). Sin embargo, parece que la degradación del $\mathrm{P}$ y de los $\mathrm{NO}_{3}{ }^{-}$no se ve afectada por esta variable.

En cambio, cuando se simula con las aportaciones futuras, todos los contaminantes se ven afectados, en mayor o menor grado, por el incremento de las afecciones en los horizontes más lejanos, sobre todo en el caso del $\mathrm{NH}_{4}{ }^{+}$y los $\mathrm{NO}_{3}{ }^{-}$. Ambos casos se pueden observar en la Fig. 26 (Apo. Futuras), que muestra como el número de masas aumenta en intervalos de incumplimientos más elevados (60\%-100\%). Esto es debido a la menor capacidad de dilución en periodos futuros, fruto de la disminución de los recursos hídricos en estos horizontes (Rocha et al., 2020; Serpa et al., 2017).

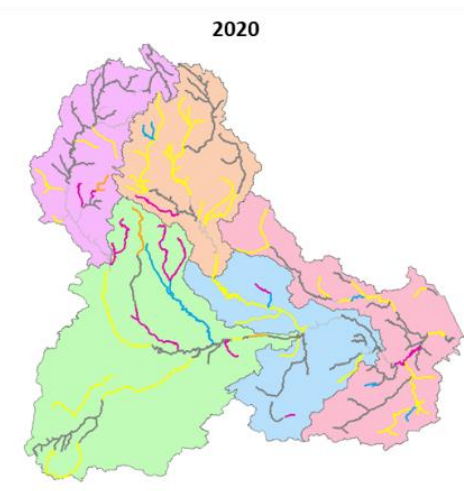

2080

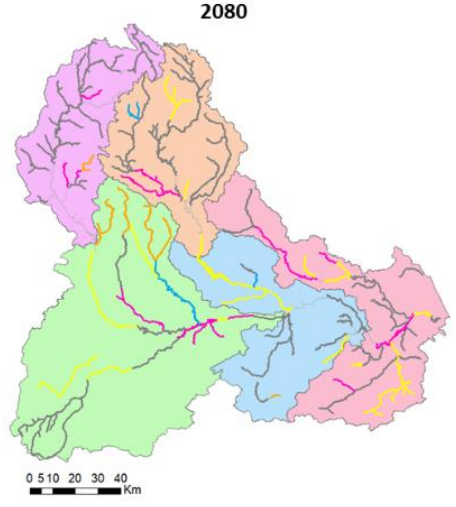

2050
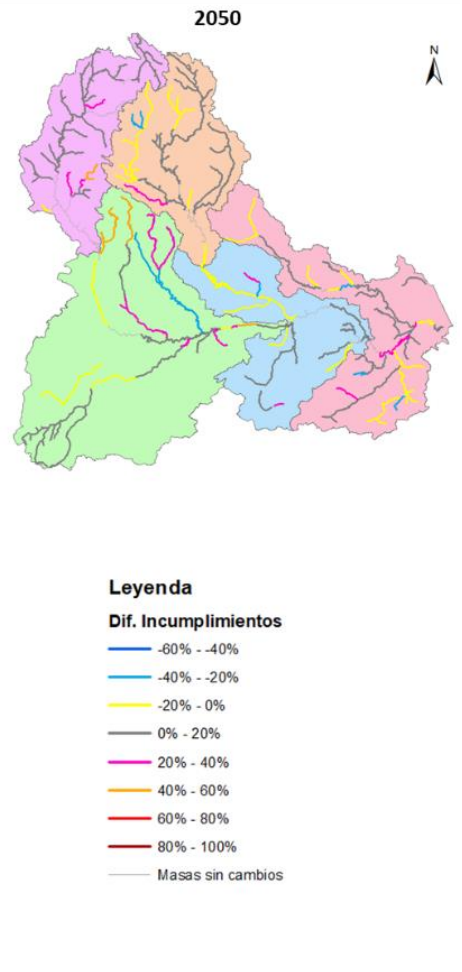

Fig. 27. Diferencia entre los incumplimientos de los horizontes futuros $(2020,2050$ y 2080 ) y los del periodo de referencia en la simulación de las aportaciones futuras para los $\mathrm{NO}_{3}$. Modificado de Suárez-Almiñana et al., (2021). 
En la Fig. 27 se presenta el caso de los $\mathrm{NO}_{3}{ }^{-}$, donde se destacan las diferencias entre los incumplimientos futuros de la simulación con aportaciones futuras y los del periodo de referencia. Se ve como en el horizonte 2020 hay algunas masas que experimentan reducciones respecto de los incumplimientos del periodo de referencia, lo que puede ser lógico debido al aumento de los recursos en este periodo. En cambio, estas diferencias van aumentando y pasando a rangos de afectación superiores conforme nos acercamos a finales de siglo.

En todos los casos, las masas más afectadas pertenecen a la subcuenca de Molinar y a la de Sueca en el caso de los $\mathrm{NO}_{3}{ }^{-}$, como en el periodo de referencia, coincidiendo con áreas afectadas en gran medida por vertidos de naturaleza urbana y zonas agrícolas (Fig. 3).

Por otro lado, en la simulación combinada (Fig. 26, $T_{a}+$ Apo. Futuras), los resultados del $\mathrm{P}$ y los $\mathrm{NO}_{3}^{-}$parecen no sufrir cambios respecto de la simulación anterior (aportaciones futuras). En cambio, tanto en el caso de la $\mathrm{DBO}_{5}$ como en el del $\mathrm{NH}_{4}{ }^{+}$se observa como en los horizontes más lejanos se producen reducciones en el número de masas pertenecientes a intervalos de afectación más elevados (60\% - 100\%), sobre todo en el caso del $\mathrm{NH}_{4}{ }^{+}$.
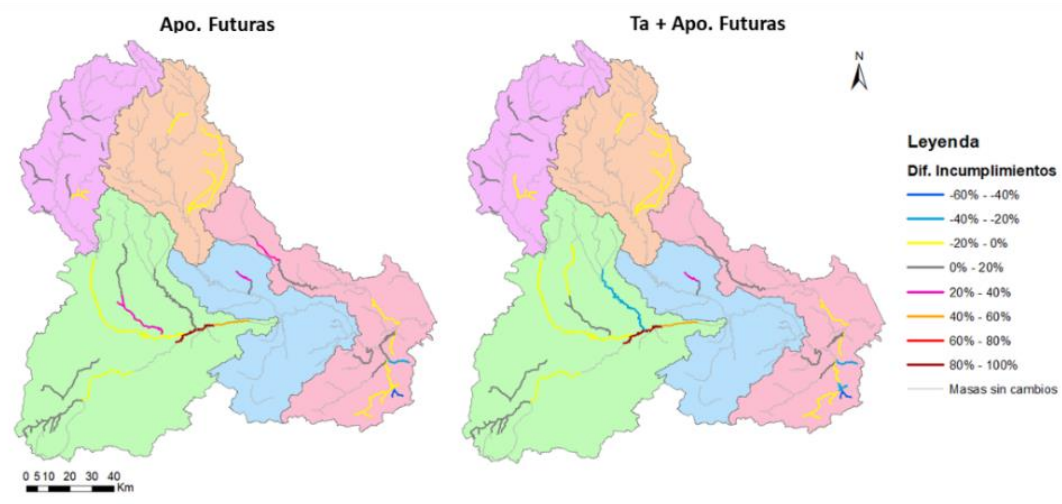

Fig. 28. Diferencia entre los incumplimientos del horizonte 2080 y los del periodo de referencia en la simulación de las aportaciones futuras (izquierda) y la de la $T_{a}$ y aportaciones futuras (derecha) para el $\mathrm{NH}_{4}{ }^{+}$. Modificado de Suárez-Almiñana et al., (2021). 
En la Fig. 28 se presenta el caso del $\mathrm{NH}_{4}{ }^{+}$en el futuro lejano de ambas simulaciones y cómo el efecto de la $\mathrm{T}_{\mathrm{a}}$ futura (Fig. 28, derecha) amortigua el incremento de afectaciones producidas por la disminución de los recursos hídricos (Fig. 28, izquierda) en alguna de las masas de agua más afectadas (Molinar y Sueca).

Como hemos mencionado anteriormente, los $\mathrm{NO}_{3}^{-}$parecen no verse afectados por la $T_{a}$, ya que los cambios entre las simulaciones es apenas perceptible. Sin embargo, se ha observado que al considerar la $T_{a}$ futura en esta simulación, las afecciones de este contaminante se incrementan, al contrario que en los otros contaminantes, aunque estos incrementos son muy bajos $(<10 \%)$ para experimentar un cambio de rango de incumplimientos (Fig. 26). Este aumento se puede deber a la estrecha relación que tiene este contaminante con el $\mathrm{NH}_{4}{ }^{+}$. Las reducciones del amonio a mayor $\mathrm{T}_{\mathrm{a}}$ implican una mayor degradación del mismo, que se convierte en nitratos, aumentando su concentración en el medio para la asimilación de las plantas.

Por lo tanto, a la vista de todos los resultados, se podría decir que la reducción de las aportaciones futuras afecta directamente al estado de las masas de agua, que registran mayores niveles de afectación en los horizontes 2050 y 2080 para todos los contaminantes, sobre todo en las subcuencas de Molinar y Sueca. Este incremento de afectaciones se compensa cuando se incluye la $T_{a}$ en la simulación de algunos contaminantes, obteniendo así un efecto combinado en el que masas afectadas experimentan reducciones importantes de incumplimientos en los horizontes futuros más alejados.

Debido a este efecto combinado, se considera necesario incluir la $T_{a}$ en este tipo de simulaciones (cuando sea posible) para la $\mathrm{DBO}_{5}$ y el $\mathrm{NH}_{4}{ }^{+}$, ya que se ha demostrado que su degradación depende en gran medida de esta variable $y$ al no considerarla se podrían estar subestimando o sobrestimando afecciones importantes. 
No obstante, este es un modelo simplificado a gran escala que se ha simulado con las características actuales del sistema, lo que introduce en el proceso cierta incertidumbre, además de la ya asociada a los datos climáticos, debida tanto a las tasas de cambio de las aportaciones como a las de la $T_{a}$. Además, los porcentajes de incumplimientos se basan en la media de cada periodo simulado, que pueden estar influenciados por los meses de verano y episodios de sequía, ya que algunos de los cauces permanecen secos en estos periodos.

Para mejorar las simulaciones de este estudio se podrían introducir varias predicciones de cambios a futuro, aunque esto también podría introducir incertidumbre en el proceso. La introducción de escenarios socioeconómicos futuros (Shared Socioeconomic Pathways - SSP) (Hunink et al., 2019; Jin et al., 2018), cambios futuros del uso del suelo (Serpa et al., 2017; Shrestha et al., 2018), tasas de reducción de la demanda agrícola (Hunink et al., 2019) y restricciones ambientales más estrictas podrían ser algunos ejemplos.

Por último, hay que destacar la situación alarmante a la que se podría enfrentar la cuenca del Júcar en el futuro debido a la disminución de los recursos hídricos, el aumento de la $\mathrm{T}_{\mathrm{a}}$ y su conexión con la calidad del agua. Por lo que se hace necesario considerar la implementación de medidas preventivas para evitar deficiencias en los suministros y repercusiones tanto ambientales como socioeconómicas en este SRH.

\subsection{Metodología para la integración de pronósticos estacionales}

En esta sección se analizan los resultados de la evaluación del riesgo de sequía mediante un indicador probabilístico de 7 meses de antelación, utilizando distintos métodos de generación de series de aportaciones (AR(1), ARMAX $(1,1,0,1)$, ANN y el HBV-SEJ), para un escenario normal 
(2003/2004) y otro seco $(2005 / 2006)$ con dos meses de inicio de simulación (octubre y marzo).

Además, la capacidad predictiva de estos métodos se evalúa comparando los volúmenes esperados en el sistema con los valores observados. De este modo, se puede evaluar el valor añadido de los pronósticos estacionales y la opción de integrarlos en la gestión de la sequía en tiempo real en función de su idoneidad frente a diferentes escenarios.
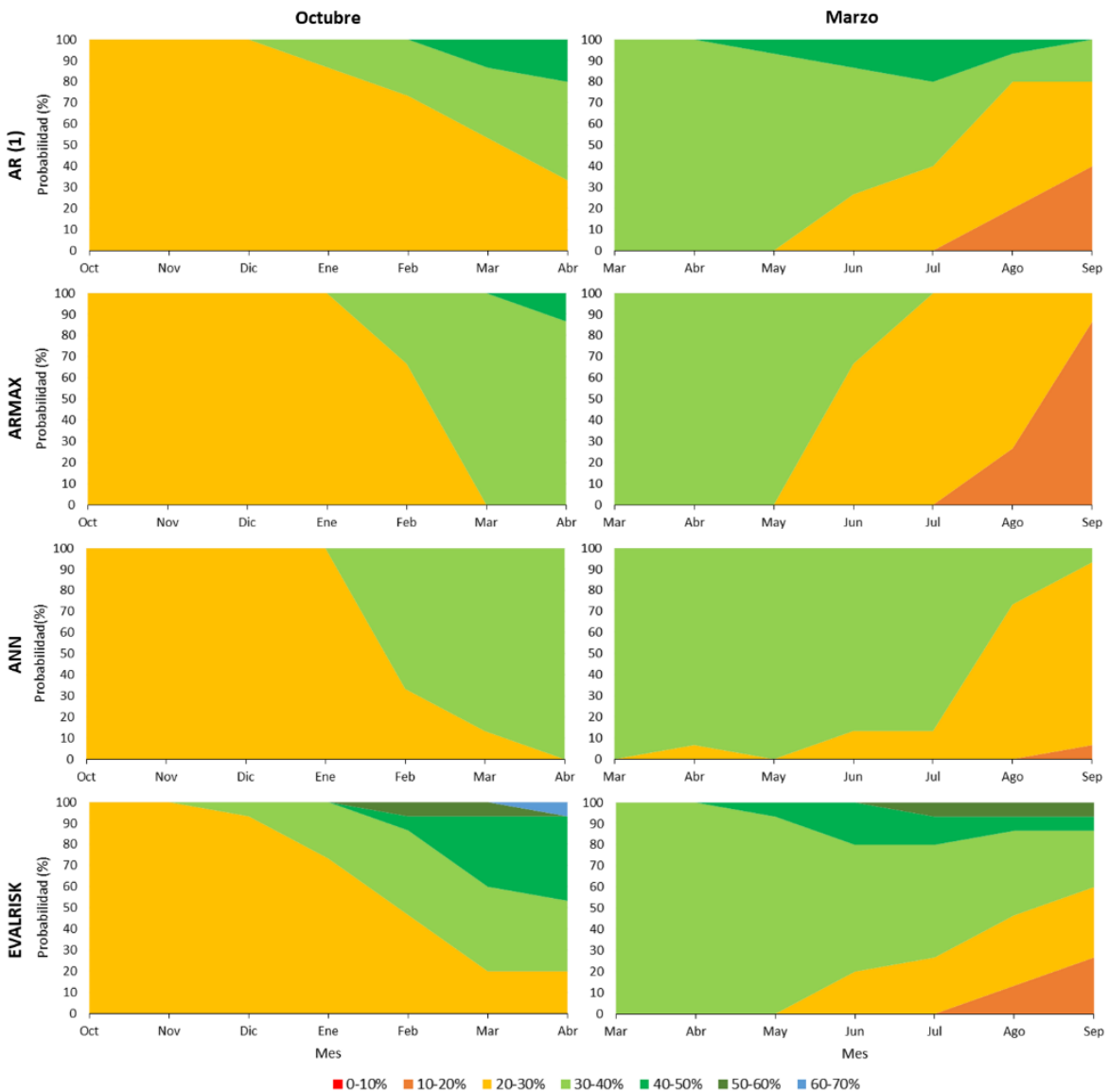

Fig. 29. Indicador del riesgo de sequía para el año normal (2003/2004) considerando varios métodos de generación de series de aportaciones en simulaciones de 7 meses a partir de octubre 2003 y marzo 2004. Modificado de Suárez-Almiñana et al. (In press). 
En las Fig. 29 y 30 se encuentran representados los indicadores del año normal y seco respectivamente, teniendo en cuenta cada alternativa metodológica, la simulación (iniciada en octubre o marzo) y que se parte de un único valor en el mes inicial, el real. De aquí en adelante, llamaremos EVALRISK a la variante desarrollada con el modelo hidrológico HBV-SEJ, ya que se desarrolló en los módulos EVALHID y SIMRISK.

De los indicadores de la Fig. 29, primero nos fijaremos en el indicador proveniente del $A R(1)$, ya que es el método utilizado actualmente para la evaluación del riesgo de sequía en esta cuenca, y que por lo tanto, sirve como punto de referencia al no integrar los pronósticos estacionales de $\mathrm{P} y$ T en la generación de caudales.

En la simulación de octubre del año normal (Fig. 29, primera línea), las probabilidades de que el sistema esté entre el $20-30 \%$ de la capacidad total del sistema son elevadas (80-100\%) desde el comienzo del año hidrológico (octubre) hasta el inicio de la temporada de riego (marzo-abril), donde estas disminuyen hasta el $40 \%$. En cambio, la simulación iniciada en marzo del mismo año muestra un escenario más optimista para los tres primeros meses, encontrándose el sistema entre el 30-40\% de la capacidad total con casi total probabilidad. Seguidamente, con la llegada del verano, estas probabilidades van disminuyendo hasta el final del año hidrológico (septiembre), donde vemos un $80 \%$ de probabilidades de encontrar el sistema por debajo de este intervalo (10-30\%).

Los indicadores provenientes del ARMAX (Fig. 29, segunda línea) son similares a los anteriores, pero con algunas peculiaridades, como que las predicciones para los meses de marzo y abril coinciden en ambas simulaciones (final de la primera e inicio de la segunda) y que los aumentos o disminuciones de las probabilidades un mes a otro son más drásticos (mayores pendientes). Además, el estado final del sistema (septiembre) presenta un peor escenario en esta simulación, ya que es más probable (80\%) que se encuentre en el intervalo volumétrico del 10-20\%. 
En el caso de la ANN (Fig. 29, tercera línea), el indicador muestra menores variabilidades. Mientras que en los casos anteriores se consideraban 4 intervalos volumétricos diferentes, en este caso la predicción sólo considera 2 de ellos en la mayoría de los meses. En general, las probabilidades de estar entre el $20-30 \%$ de la capacidad total del sistema de octubre a enero y entre el 30-40\% de febrero a abril son más elevadas que en los casos anteriores. Por el contrario, en la simulación de marzo, es más probable que el sistema se encuentre en el intervalo volumétrico $30-40 \%$ de marzo a julio y en el de $20-30 \%$ para los últimos meses del año.

Los indicadores de EVALRISK (Fig. 29, última línea) son más parecidos a los procedentes del $A R(1)$, debido a la menor pendiente entre probabilidades y a la mayor variabilidad de los resultados. En este caso, se consideran más de 4 intervalos volumétricos, que se encuentran sobre todo al final de ambas simulaciones. Las probabilidades de encontrarse en el intervalo volumétrico del $20-30 \%$ disminuyen gradualmente desde octubre (100\%) hasta abril (20\%), cuando es más probable que el sistema se encuentre entre el $30-50 \%$ de su capacidad total. En la simulación de marzo, las probabilidades de encontrar el sistema en el intervalo del 30 $40 \%$ también van disminuyendo progresivamente desde el $100 \%$ (marzo) al $20 \%$ (septiembre). Sin embargo, en septiembre existe la misma probabilidad (50\%) de quedarse por debajo o sobrepasar el $30 \%$ de la capacidad total del sistema.

Por otro lado, en los indicadores provenientes del $A R(1)$ del año seco (Fig. 30, primera línea), las probabilidades de encontrar el sistema al 10$20 \%$ de su capacidad total son mayores del $60 \%$ (en general) en ambas simulaciones. Además, las probabilidades de tener todavía menores recursos hídricos en el sistema (0-10\%) aumentan de junio a septiembre hasta llegar al 50\%. 

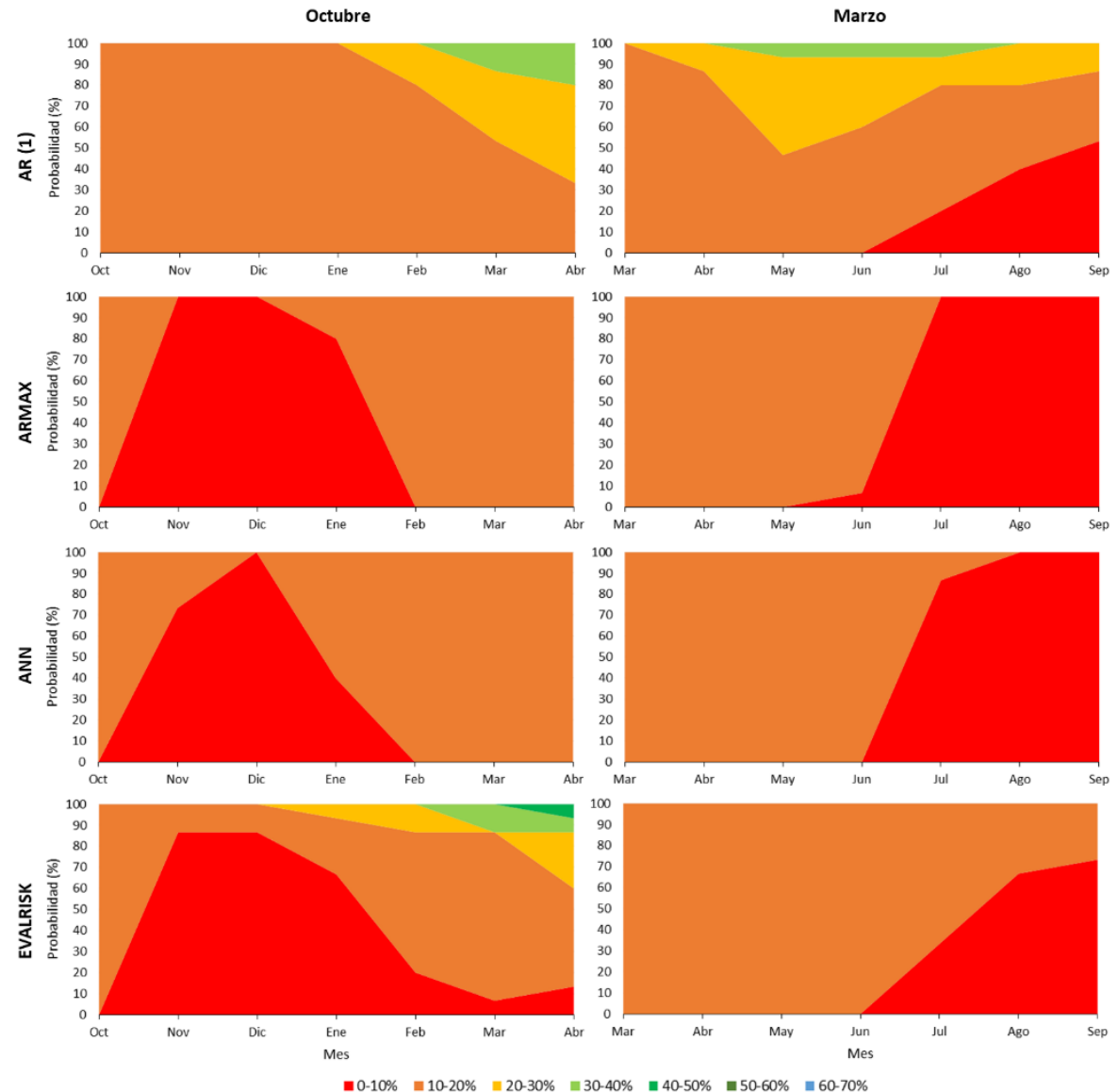

Fig. 30. Indicador del riesgo de sequía para el año seco (2005/2006) considerando varios métodos de generación de series de aportaciones en simulaciones de 7 meses a partir de octubre 2005 y marzo 2006. Modificado de Suárez-Almiñana et al. (In press).

En el caso del ARMAX (Fig. 30, segunda línea), los resultados son más alarmantes que los del $A R(1)$, ya que de octubre a febrero se prevé una situación complicada, con casi total probabilidad de estar bajo mínimos (intervalo $0-10 \%$ ) en los meses de noviembre y diciembre. Sin embargo, parece que el sistema se recupera a partir de enero, ya que entre febrero y abril el sistema se encuentra en un intervalo volumétrico superior (10-20\%) con total probabilidad. En la simulación de marzo esta situación se mantiene hasta junio, pero a partir de julio el sistema se encuentra en el 
mínimo de capacidad (0-10\%) con total probabilidad, coincidiendo con la estación de riego y verano.

Los indicadores de la ANN (Fig. 30, tercera línea) son muy similares a los anteriores (ARMAX), donde se prevé la misma situación complicada de octubre a febrero y de junio a septiembre, pero con menores probabilidades de encontrarse bajo mínimos en la simulación de octubre.

Por último, los indicadores de EVALRISK (Fig. 30, última línea) muestran probabilidades elevadas (70-85\%) de encontrar el sistema por debajo del $10 \%$ de su capacidad total entre los meses de noviembre y enero. Sin embargo, de febrero a abril se consideran otros intervalos más altos, pero con probabilidades más bajas $(<30 \%)$, siendo más probable $(50-70 \%)$ que el sistema se encuentre en el intervalo volumétrico del $10-20 \%$ en estos meses. Por otro lado, la variabilidad de los últimos meses en la simulación de octubre contrasta con los resultados de la simulación de marzo, donde se observa una situación preocupante al final del año hidrológico, con probabilidades elevadas (75\%) de estar por debajo del $10 \%$ de la capacidad total del sistema.

Una vez analizados los indicadores, parece que la variabilidad de los resultados es mayor cuando para la generación de series solo se utilizan aportaciones antecedentes $(\mathrm{AR}(1))$ o cuando se utilizan pronósticos estacionales de $\mathrm{P}$ y $\mathrm{T}$ con el modelo hidrilógico (EVALRISK). Sin embargo, parece que el uso conjunto de estos datos (ARMAX y ANN) podrían aportar resultados más robustos y fiables, con menor variabilidad, especialmente en el final de las simulaciones, es decir, más allá de los 3 meses considerados con suficiente capacidad predictiva estimada en la literatura (Arnal et al., 2018; Crochemore et al., 2020; Grillakis et al., 2018; Li et al., 2017; Macian-Sorribes et al., 2020; Wanders et al., 2019). Además, en el caso del ARMAX y la ANN, los resultados de los últimos meses de la simulación de octubre coinciden con los primeros de la simulación de marzo. No obstante, esta falta de variabilidad también puede indicar que se trabaja con pocos miembros del ensamblado o que en el proceso de 
corrección del sesgo se limitó la variabilidad de los pronósticos (Madrigal Barrera, 2020).

Por otro lado, si tenemos en cuenta que en el año normal el volumen final en septiembre fue de $579 \mathrm{hm}^{3}$ (intervalo 30-40\%) y en el año seco de $107 \mathrm{hm}^{3}$ (intervalo 0\%-10\%), se podría decir que el enfoque EVALRISK es el que está más acertado en el año normal y el ARMAX y la ANN en el año seco a la hora de predecir el estado final del sistema, ya que presentan mayores probabilidades de encontrarse en esos intervalos volumétricos.

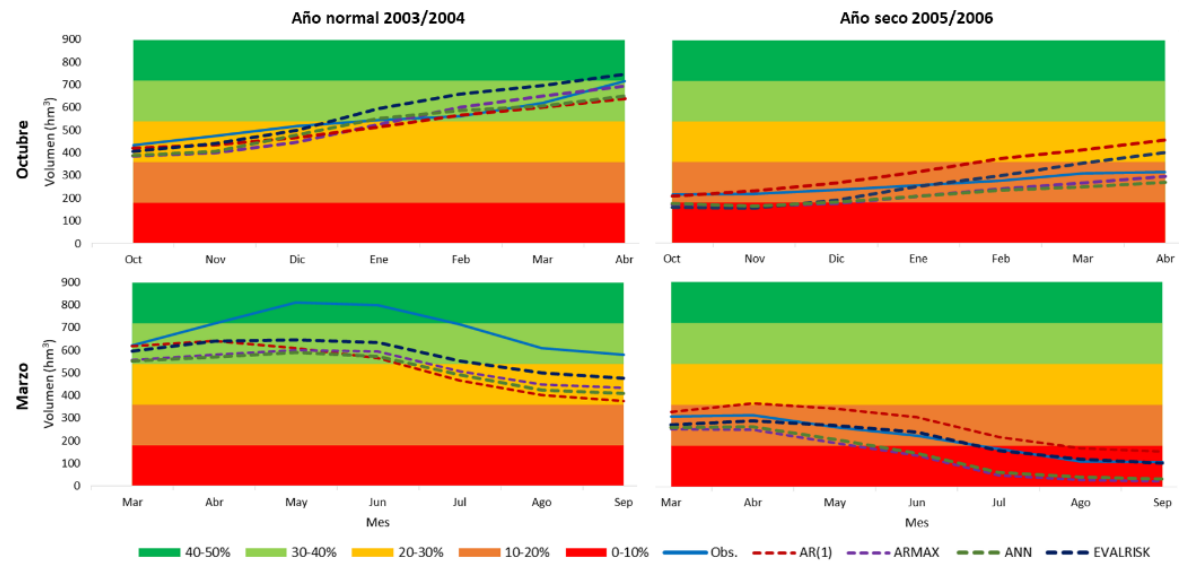

Fig. 31. Volúmenes de almacenamiento en el sistema observados y esperados procedentes de varios métodos de generación de series de aportaciones, dentro de los intervalos volumétricos de $0-50 \%$ del total del sistema para las simulaciones de octubre y marzo de los años normal y seco. Modificado de Suárez-Almiñana et al. (In press).

Para evaluar la capacidad predictiva de estos métodos, en la Fig. 31 se muestran los valores volumétricos esperados para cada uno de ellos junto con los valores observados, presentados por año y simulación para su comparación. Además, en la Tabla 3 se muestran los valores medios del Continuous Ranked Probability Score (CRPS) (Zamo y Naveau, 2018) para estimar la pericia predictiva de los diferentes métodos en esta comparación, donde el valor 0 indica una coincidencia perfecta entre los pronósticos y los valores observados. 
En términos generales, los valores esperados de todas las alternativas estudiadas se acercan bastante a los valores observados (sobre todo en los primeros meses de la simulación), o al menos se encuentran en el mismo rango volumétrico en ambas simulaciones, a excepción de la de marzo del año normal (Fig. 31, abajo a la izquierda) y de los últimos meses de la simulación de octubre del año seco (AR(1) y EVALRISK).

Tabla 3. Valores medios del CRPS por método, año y simulación de los resultados mostrados en la Fig. 31. Modificado de Suárez-Almiñana et al. (In press).

\begin{tabular}{c|c|c|c|c} 
Simulación & AR(1) & ARMAX & ANN & EVALRISK \\
\hline Oct 2003 & $\mathbf{3 4 . 0 4}$ & 42.99 & 38.07 & 48.36 \\
\hline Mar 2004 & 167.32 & 161.06 & 176.89 & $\mathbf{1 1 4 . 8 4}$ \\
\hline Oct 2005 & 65.76 & $\mathbf{4 3 . 6 7}$ & 46.91 & 48.80 \\
\hline Mar 2006 & 56.31 & 78.66 & 67.67 & $\mathbf{1 4 . 9 0}$
\end{tabular}

Además, según los valores de la Tabla 3, se podría concluir que el mejor predictor para las simulaciones de marzo es EVALRISK, a pesar del desajuste en el año normal. Sin embargo, esto se puede deber al alto grado de desarrollo de los modelos, ya que el modelo hidrológico maneja más información que los demás métodos y considera la conexión superficial con la subterránea (Suárez-Almiñana et al., 2017), además de que las condiciones iniciales del sistema son conocidas (Arnal et al., 2018; Wanders et al., 2019). También, puede que la pericia de los pronósticos estacionales en primavera y verano haya mejorado tras la corrección del sesgo. En cambio, esta conclusión podría ser diferente en sistemas en los que no haya tanta experiencia en la gestión de los recursos hídricos o simplemente porque no haya suficientes datos para calibrar adecuadamente un modelo hidrológico.

Por otro lado, para las simulaciones de octubre no existe un patrón claro. Sin embargo, para esta simulación en el año seco parece que las mejores opciones son los modelos ARMAX y ANN, que además proporciona predicciones ligeramente inferiores a las observadas (al contrario que el $A R(1)$ ), lo que puede ser una ventaja desde el punto de vista de la toma de decisiones, ya que de este modo se tomarían desde el lado de la seguridad. 
También es importante señalar que el modelo de evaluación de riesgos tiene integradas las reglas de funcionamiento del sistema, lo que significa que las restricciones de suministro se aplican directamente cuando los caudales de entrada son bajos. No obstante, los volúmenes observados de la Fig. 31 se corresponden a las medidas tomadas en ese momento, que pueden no coincidir exactamente con las medidas adoptadas por el modelo, por lo que existe cierta incertidumbre sobre qué método tiene mejor capacidad de predicción en este aspecto.

Sin embargo, los resultados son prometedores, ya que sus capacidades predictivas son (en general) superiores a las del método actual, especialmente en el escenario de sequía, pudiendo ofrecer grandes expectativas en su gestión en tiempo real. En cambio, las diferencias entre ellos no son significativas y es necesario seguir investigando, por ejemplo probando más periodos históricos, otras técnicas de post-procesamiento (Grillakis et al., 2017; Macian-Sorribes et al., 2020) y/o utilizando pronósticos estacionales con ensamblados más numerosos, que podrían proporcionar predicciones de mayor calidad pero al mismo tiempo introducir más incertidumbre en el proceso (Li et al., 2017). Además, también se hace necesaria la mejora de la capacidad predictiva de los pronósticos estacionales en la zona mediterránea.

No obstante, la implementación de estas mejoras no garantiza el uso de los pronósticos estacionales en este ámbito si los gestores de cuenca siguen sin confiar en ellos cuando estén disponibles a tiempo real. Además, otro factor a tener en cuenta es su libre disponibilidad, ya que la situación económica de la cuenca puede condicionar su uso (Arnal et al., 2016).

En cualquier caso, las metodologías presentadas en este estudio se pueden considerar como un primer paso para gestionar los sistemas de forma anticipada con previsiones certeras en tiempo real, ya que actualmente se toman medidas por imitación de experiencias anteriores. 


\section{CONCLUSIONES}

El principal objetivo de esta tesis es mejorar y facilitar el proceso de toma de decisiones en el ámbito de la gestión y planificación hidrológica frente a futuros impactos derivados del cambio climático, sobre todo relacionados con eventos de sequía (cada vez más recurrentes e intensos) que no solo afectan a la escasez de agua, sino también a su calidad.

Para cumplir con este objetivo, se desarrollaron varias metodologías que permiten la integración de pronósticos estacionales y proyecciones climáticas en una cadena de modelos con el fin de obtener indicadores del riesgo de sequía a medio y largo plazo. Estas metodologías se testaron en la cuenca del Júcar, ya que se trata de un sistema altamente regulado y con una elevada variabilidad hidrológica, que en la actualidad se enfrenta a periodos recurrentes y multianuales de sequía.

Las metodologías presentadas a corto y largo plazo son prometedoras, fiables y robustas, con resultados preocupantes e inciertos para el futuro de la cuenca de estudio en términos cualitativos y cuantitativos.

En las siguientes secciones se aporta un resumen de las publicaciones pertenecientes a esta tesis, donde se desarrollan todas estas metodologías, además de las principales aportaciones y futuras líneas de investigación.

\subsection{Resumen}

Esta tesis se compone de cinco artículos científicos, cuatro de ellos publicados en revistas de reconocido prestigio (Science of the Total Environment, Hydrology and Earth System Sciences e Ingeniería del Agua) y otro artículo en proceso de publicación en el Journal of Hydrology, también de reconocido prestigio. 
Tres de los artículos publicados se centran en el desarrollo de una metodología de integración de las proyecciones climáticas (ajustadas y corregidas) en una cadena de varios modelos (hidrológico, estocástico, de gestión y de evaluación del riesgo), haciendo hincapié en cada paso e identificando i tratando de resolver los problemas encontrados en su aplicación al caso de estudio. De este proceso se pueden extraer varios resultados, como tasas medias de cambio de las aportaciones futuras, recursos hídricos almacenados en el sistema y un indicador de riesgo de sequía basado en la evolución probabilística de los recursos almacenados en el sistema, todo ello para tres periodos futuros: el cercano (horizonte 2020), el medio (horizonte 2050) y el lejano (horizonte 2080).

El cuarto artículo publicado parte de la aplicación de las tasas medias de cambio futuras (obtenidas previamente) a las aportaciones de cada masa de agua del caso de estudio, que posteriormente fueron introducidas en un modelo de calidad del agua a gran escala. Además, en este modelo también se tuvo en cuenta la temperatura del agua (histórica y futura). De esta forma, se estimó el efecto del cambio climático en la calidad del agua futura para los horizontes 2020, 2050 y 2080, además de evaluar el efecto de la temperatura del agua en la degradación de algunos contaminantes.

Por último, el quinto artículo, en proceso de publicación, aborda la integración de pronósticos estacionales en la evaluación del riesgo de sequía en tiempo real. Para ello se utilizaron varios métodos de generación de series de aportaciones previos al modelo de evaluación de riesgo, para obtener el indicador de riesgo de sequía a medio plazo. Estos métodos incluyen de una forma u otra los pronósticos estacionales y en algunos de ellos se combinan con aportaciones previas. Se trata de un modelo hidrológico, un modelo estocástico con variable exógena y un modelo de redes neuronales artificiales. Los resultados de estos modelos se compararon con datos observados y con el método utilizado actualmente en este proceso, un modelo estocástico que no incorpora ningún tipo de 
pronóstico y basa la generación de series en aportaciones previas, con el fin de evaluar sus capacidades predictivas o la idoneidad de cada método.

\subsection{Principales aportaciones de la tesis}

La principal aportación de esta tesis es una propuesta completa de metodologías de inclusión de pronósticos estacionales y proyecciones climáticas en la gestión y planificación hidrológicas, utilizando para ello herramientas enfocadas a una gestión eficaz de los recursos hídricos a medio y largo plazo, que se desarrollaron para prever episodios extremos de sequía y sus posibles impactos mediante la evaluación del riesgo.

Dentro de la línea del análisis a largo plazo (planificación) se proponen varios enfoques que se complementan (determinísticos y probabilísticos) y se aportan resultados como las tasas medias de cambio de aportaciones futuras, que se pueden utilizar en otros estudios de la cuenca con otros propósitos. Esto mismo se ha realizado en esta tesis en el artículo de la evaluación de la calidad del agua bajo la influencia del cambio climático, lo cual supone una aportación original. Además, en ese artículo también se tuvo en cuenta la temperatura del agua futura en la simulación, siendo esta variable decisiva en la degradación de algunos contaminantes e imprescindible para no sobreestimar o subestimar sus afecciones en las masas de agua.

Otra aportación ha sido la aplicación de varios ajustes y correcciones a los datos para que representen la situación actual de la cuenca a fin de reducir la incertidumbre a la hora de estimar las tasas medias de cambio de las aportaciones futuras. Una aportación adicional ha sido la propuesta y utilización de un período de referencia diferente para la cuenca del Júcar, más adaptado al efecto 80 , lo que ha servido para recalcar la importancia de mencionar el periodo de referencia utilizado cuando se hacen afirmaciones acerca de la magnitud de estos cambios futuros. 
Por otro lado, una de las primeras aportaciones de los trabajos expuestos en esta tesis ha sido demostrar que los caudales provenientes de los modelos hidrológicos a gran escala (p.e. escala europea) no son capaces de captar las características de cuencas más pequeñas, sobre todo aquellas altamente reguladas en las que la conexión entre el acuífero y el rio es determinante para la gestión de los recursos del sistema. Por este motivo, se propuso la utilización de los pronósticos y proyecciones corregidos en un modelo hidrológico a escala de cuenca propiamente calibrado y validado, garantizando así una representación más adecuada de las características hídricas de la cuenca.

Dentro de la línea de gestión del recurso y de las sequías (medio plazo), como aportación original se han propuesto tres opciones para generar series de aportaciones futuras integrando pronósticos estacionales (corregidos) en la gestión de la sequía en tiempo real. Se ha evaluado y comparado las prestaciones de todas ellas, demostrando que los resultados son prometedores. Esto se debe principalmente al gran desarrollo de los modelos utilizados y a la combinación de las aportaciones precedentes con estos pronósticos, obteniendo una capacidad predictiva aceptable más allá de los 3 meses establecidos en la literatura y mejorando la del método utilizado en la actualidad, que solamente utiliza las aportaciones precedentes.

\subsection{Futuras líneas de investigación}

Como resultado de esta investigación, se han identificado varias líneas de estudio en las que se debería profundizar.

En primer lugar, se hace necesaria la mejora de los modelos climáticos con los que se extraen los pronósticos y las proyecciones climáticas, sobre todo en la vertiente mediterránea donde su capacidad predictiva es baja, lo que en algunos casos inhabilita estos datos para la toma de decisiones. 
Además, los métodos de corrección del sesgo más extendidos parecen no ser suficiente para obtener resultados satisfactorios en este caso, por lo que una corrección estacional o basada en los estadísticos de sequías históricas podría ser más apropiada.

También se hace patente la necesidad de implementar predictores a escala hiperanual y criterios de validación de los modelos en base a la predicción de sequías, mejorando así la memoria que mantienen los modelos climáticos y matemáticos utilizados.

Por otro lado, se debería abordar la evolución de las demandas a largo plazo, como lo hizo Hernández Barrios (2007), relacionándolas con los incrementos de temperatura previstos para horizontes futuros y obteniendo así mejores estimaciones, ya que las simulaciones a futuro se realizan normalmente con las condiciones actuales del sistema. Este aspecto no se llevo a cabo en esta tesis debido a las limitaciones temporales y las preferencias por explorar otros ámbitos como el de la calidad del agua y los pronósticos estacionales.

Por último, hay que profundizar más en el estudio de la calidad de las masas del agua en el futuro, incrementando el detalle a menores escalas y estudiando las relaciones entre las variables y los contaminantes más problemáticos de la cuenca.

\section{REFERENCIAS}

Andreu, J., Capilla, J., Sanchís, E., 1996. AQUATOOL, a generalized decisionsupport system for water-resources planning and operational management. J. Hydrol. 177, 269-291. doi:10.1016/00221694(95)02963-X

Andreu, J., Ferrer-Polo, J., Pérez, M.A., Solera, A., 2009. Decision support system for drought planning and management in the Jucar river basin, Spain, in: Proceedings of the 18th world IMACS/MODSIM Congress, 
13-17 July 2009, Cairns, Australia, 3223-3229.

Andreu, J., Ferrer-Polo, J., Pérez, M.A., Solera, A., Paredes-Arquiola, J., 2013. Drought Planning and Management in the Júcar River Basin, Spain, in: Schwabe, K., Et, A. (Eds.), Drought in Arid and Semi-Arid Regions: A Multi-Disciplinary and Cross-Country Perspective. pp. 1-21. doi:10.1007/978-94-007-6636-5

Andreu, J., Solera, S., Capilla, J., Ferrer, J., 2007. Modelo SIMGES de Simulación de la Gestión de Recursos Hídricos, incluyendo Utilización Conjunta, Manual de usuario, versión 3.03.01, Universitat Politècnica de València, Valencia, España.

Arnal, L., Cloke, H.L., Stephens, E., Wetterhall, F., Prudhomme, C., Neumann, J., Krzeminski, B., Pappenberger, F., 2018. Skilful seasonal forecasts of streamflow over Europe? Hydrol. Earth Syst. Sci. 22, 2057-2072. doi:10.5194/hess-22-2057-2018

Arnal, L., Ramos, M.H., De Perez, E.C., Cloke, H.L., Stephens, E., Wetterhall, F., Van Andel, S.J., Pappenberger, F., 2016. Willingness-to-pay for a probabilistic flood forecast: A risk-based decision-making game. Hydrol. Earth Syst. Sci. 20, 3109-3128. doi:10.5194/hess-20-31092016

Barranco, L., Dimas, M., Jiménez, A., Estrada, F., 2018. Nueva evaluación del impacto futuro del cambio climático en los recursos hídricos en España. Ingeiría Civ. 191/2008, 34-55.

Bergström, S., 1995. The HBV Model, in: Computer Models of Watershed Hy-Drology, Water Resources Publications, Highlands Ranch. Colorado, pp. 443-476.

BOE, 2015. Real Decreto 817/2015, de 11 de septiembre, por el que se establecen los criterios de seguimiento y evaluación del estado de las aguas superficiales y las normas de calidad ambiental, Actualidad Jurídica Ambiental.

Box, G., Jenkins, G., Reinsel, G., Ljung, G., 2016. Time Series Analysis: Forecasting and Control. Wiley, Hoboken, New Jersey. 
CEDEX, 2017. Evaluación del impacto del cambio climático en los recursos hídricos y sequías de España. Informe Técnico Centro de Estudios Hidrográficos - CEDEX, Tomo único, clave CEDEX 42-415-0-001, Centro de Publicaciones, Secretaría General Técnica del Ministerio de Fomento, Madrid, España.

CEDEX, 2010. Estudio de los impactos del cambio climático en los recursos hídricos y las masas de agua. Ficha 1: Evaluación del impacto del cambio climático en los recursos hídricos en régimen natural. Informe Técnico Centro de Estudios Hidrográficos - CEDEX, Tomo único, clave CEDEX 42-407-1-001, Centro de Publicaciones, Secretaría General Técnica del Ministerio de Fomento, Madrid, España.

Chatterjee, S., Daniels, M.D., Sheshukov, A.Y., Gao, J., 2018. Projected climate change impacts on hydrologic flow regimes in the Great Plains of Kansas. River Res. Appl. 34, 195-206. doi:10.1002/rra.3249

CHJ, 2018. Plan Especial de Sequía Demarcación Hidrográfica del Júcar, Ministerio de Agricultura y Pesca, Alimentación y Medio Ambiente, Valencia, España.

CHJ, 2015. Plan Hidrológico de la Demarcación Hidrográfica del Júcar, Memoria cliclo de planificación hidrológica 2015-2021, Ministerio de Agricultura, Alimentación y Medio Ambiente, Valencia, España.

CHJ, 2010. Informe post-sequía 2005-2008. Apartado 10 PES, Ministerio de Medio Ambiente y Medio Rural y Marino, Valencia, España.

$\mathrm{CHJ}$, 2007. Plan Especial de Actuación en Situación de Alerta y Eventual Sequía de la Demarcación Hidrográfica del Júcar, Ministerio de Medio Ambiente, Valencia, España.

Collados-Lara, A.J., Pulido-Velazquez, D., Pardo-Igúzquiza, E., 2018. An integrated statistical method to generate potential future climate scenarios to analyse droughts. Water 10 (9), 1224. doi:10.3390/w10091224

Cook, B.I., Miller, R.L., Seager, R., 2008. Dust and sea surface temperature forcing of the 1930s "Dust Bowl" drought. Geophys. Res. Lett. 35, 1-5. doi:10.1029/2008GL033486 
Crochemore, L., Ramos, M.H., Pappppenberger, F., Van Andel, S.J., Wood, A.W., 2016. An experiment on risk-based decision-making in water management using monthly probabilistic forecasts. Bull. Am. Meteorol. Soc. 97, 541-551. doi:10.1175/BAMS-D-14-00270.1

Crochemore, L., Ramos, M.H., Pechlivanidis, I.G., 2020. Can Continental Models Convey Useful Seasonal Hydrologic Information at the Catchment Scale? Water Resour. Res. 56, 1-21. doi:10.1029/2019WR025700

Donnelly, C., Andersson, J.C.M., Arheimer, B., 2016. Using flow signatures and catchment similarities to evaluate the E-HYPE multi-basin model across Europe. Hydrol. Sci. J. 6667, 255-273. doi:10.1080/02626667.2015.1027710

Ehret, U., Zehe, E., Wulfmeyer, V., Warrach-Sagi, K., Liebert, J., 2012. HESS Opinions "should we apply bias correction to global and regional climate model data?" Hydrol. Earth Syst. Sci. 16, 3391-3404. doi:10.5194/hess-16-3391-2012

EP (European Parliament), 2000. Directive 2000/60/EC of the European Parliament and of the Council of 23 October 2000 Establishing a Framework for Community Action in the Field of Water Policy. Official Journal, Brussels.

Estrela, T., Sancho, T.A., 2016. Drought management policies in Spain and the European Union: from traditional emergency actions to Drought Management Plans. Water Policy 18, 153-176. doi:10.2166/wp.2016.018

Estrela, T., Vargas, E., 2012. Drought Management Plans in the European Union. The Case of Spain. Water Resour. Manag. 26, 1537-1553. doi:10.1007/s11269-011-9971-2

Folton, N., Martin, E., Arnaud, P., L'Hermite, P., Tolsa, M., 2019. A 50-year analysis of hydrological trends and processes in a Mediterranean catchment. Hydrol. Earth Syst. Sci. 23, 2699-2714. doi:10.5194/hess23-2699-2019

García-Romero, L., Paredes-Arquiola, J., Solera, A., Belda, E., Andreu, J., 
Sánchez-Quispe, S.T., 2019. Optimization of the multi-start strategy of a direct-search algorithm for the calibration of different rainfall-runoff models for the water resources assessment. Water 11 (9), 1876. doi:10.3390/w11091876

Govindaraju, R.S., Rao, A.R., 2000. Artificial neural networks in hydrology. Kluwer Academic Publishers, Dordrecht, Netherlands.

Grillakis, M., Koutroulis, A., Tsanis, I., 2018. Improving seasonal forecasts for basin scale hydrological applications. Water 10 (11), 1593. doi:10.3390/w10111593

Grillakis, M.G., Koutroulis, A.G., Daliakopoulos, I.N., Tsanis, I.K., 2017. A method to preserve trends in quantile mapping bias correction of climate modeled temperature. Earth Syst. Dyn. 8, 889-900. doi:10.5194/esd-8-889-2017

Groot, S., Wegman, C., Schasfoort, F., Andreu, J., Solera, A., SuárezAlmiñana, S., 2019. Application of multihazard drought risk management tool. IMPREX project report, Netherlands.

Hargreaves, G.H., Samani, Z.A., 1985. Reference crop evapotranspiration from temperature. Appl. Eng. Agric. 1 (2), 96-99.

Haro-Monteagudo, D., 2014. Methodology for the optimal management design of water resources system under hydrologic uncertainty. Tesis Doctoral, Universitat Politècnica de València, Valencia, España, 373 pp.

Haro-Monteagudo, D., Solera, A., Andreu, J., 2017. Drought early warning based on optimal risk forecasts in regulated river systems: Application to the Jucar River Basin (Spain). J. Hydrol. 544, 36-45. doi:10.1016/j.jhydrol.2016.11.022

Hernández Barrios, L., 2007. Efectos del cambio climático en los sistemas complejos de recursos hídricos. Aplicación a la cuenca del Júcar. Tesis Doctoral, Universitat Politècnica de València, Valencia, España, 243pp.

Hernández Bedolla, J., Solera, A., Paredes Arquiola, J., Roblero Escobar, C.X., 2019. Análisis del cambio en las aportaciones hidrológicas en la 
cuenca del río Júcar a partir de 1980 y sus causas. Ing. del agua 23, 141-155. doi:10.4995/ia.2019.10582

Herrera, S., Fernández, J., Gutiérrez, J.M., 2016. Update of the Spain02 gridded observational dataset for EURO-CORDEX evaluation: Assessing the effect of the interpolation methodology. Int. J. Climatol. 36, 900908. doi:10.1002/joc.4391

Herrera, S., Gutiérrez, J.M., Ancell, R., Pons, M.R., Frías, M.D., Fernández, J., 2012. Development and analysis of a 50-year high-resolution daily gridded precipitation dataset over Spain (Spain02). Int. J. Climatol. 32, 74-85. doi:10.1002/joc.2256

Hewitt, C., Buontempo, C., Newton, P., 2013. Using climate predictions to better serve society's needs. Eos Trans. AGU, 94, 105-107. doi:10.1002/2013EO110002doi:10.1002/2013EO110002

Higham, D.J., Higham, N.J., 2016. MATLAB guide. Society for Industrial and Applied Mathematics, Philadelphia, PA, USA.

Hundecha, Y., Arheimer, B., Donnelly, C., Pechlivanidis, I., 2016. A regional parameter estimation scheme for a pan-European multi-basin model. J. Hydrol. Reg. Stud. 6, 90-111. doi:10.1016/j.ejrh.2016.04.002

Hunink, J., Simons, G., Suárez-Almiñana, S., Solera, A., Andreu, J., Giuliani, M., Zamberletti, P., Grillakis, M., Koutroulis, A., Tsanis, I., Schasfoort, F., Contreras, S., Ercin, E., Bastiaanssen, W., 2019. A simplified water accounting procedure to assess climate change impact on water resources for agriculture across different European river basins. Water 11 (10), 1976. doi:10.3390/w11101976

IPCC, 2014. Summary for Policymakers, Climate Change 2014: Synthesis Report. Contribution of Working Groups I, II and III to the Fifth Assessment Report of the Intergovernmental Panel on Climate Change. Geneva, Switzerland. doi:10.1017/CBO9781107415324

IPCC, 2007. Climate Change 2007: Synthesis Report. Contribution of Working Groups I, II and III to the Fourth Assessment Report of the Intergovernmental Panel on Climate Change. Geneva, Switzerland. 
Jin, L., Whitehead, P.G., Rodda, H., Macadam, I., Sarkar, S., 2018. Simulating climate change and socio-economic change impacts on flows and water quality in the Mahanadi River system, India. Sci. Total Environ. 637-638, 907-917. doi:10.1016/j.scitotenv.2018.04.349

Lavers, D.A., Ramos, M.H., Magnusson, L., Pechlivanidis, I., Klein, B., Prudhomme, C., Arnal, L., Crochemore, L., Hurk, B. Van Den, Weerts, A.H., Harrigan, S., Cloke, H.L., Richardson, D.S., Pappenberger, F., 2020. A vision for hydrological prediction. Atmosphere (Basel). 11, 112. doi:10.3390/atmos 11030237

Lemos, M.C., Rood, R.B., 2010. Climate projections and their impact on policy and practice. Wiley Interdiscip. Rev. Clim. Chang. 1, 670-682. doi:10.1002/wcc.71

Li, Y., Giuliani, M., Castelletti, A., 2017. A coupled human-natural system to assess the operational value of weather and climate services for irrigated agriculture. Hydrol. Earth Syst. Sci. Discuss. 1-27. doi:10.5194/hess-2017-304

Liu, J., Yang, H., Gosling, S.N., Kummu, M., Flörke, M., Pfister, S., Hanasaki, N., Wada, Y., Zhang, X., Zheng, C., Alcamo, J., Oki, T., 2017. Water scarcity assessments in the past, present, and future. Earth's Futur. 5, 545-559. doi:10.1002/2016EF000518

Macian-Sorribes, H., Pechlivanidis, I., Crochemore, L., Pulido-Velazquez, M., 2020. Fuzzy postprocessing to advance the quality of continental seasonal hydrological forecasts for river basin management. J. Hydrometeorol. 21, 2375-2389. doi:10.1175/JHM-D-19-0266.1

Madrigal Barrera, J., 2020. Análisis de pronósticos climáticos para la previsión de sequías meteorológicas e hidrológicas. Tesis Doctoral, Universitat Politècnica de València, Valencia, España, 242 pp.

MARM (Ministerio de Medio Ambiente y Medio Rural y Marino), 2008. Instrucción de Planificación Hidrológica. ORDEN ARM/2656/2008, de 10 de septiembre, por la que se aprueba la instrucción de planificación hidrológica.

Manne, D., Tachikawa, Y., Ichikawa, Y., Yorozu, K., 2017. Evaluation of Bias 
Correction Methods for Future River Discharge Projection. J. Jpn. Soc. Civ. Eng. Ser., 72, 1-16. doi:10.2208/jscejer.72.i_7

Marcos-Garcia, P., Pulido-Velazquez, M., 2017. Cambio climático y planificación hidrológica: ¿es adecuado asumir un porcentaje único de reducción de aportaciones para toda la demarcación? Ing. del agua 21, 35. doi:10.4995/ia.2017.6361

Molteni, F., Stockdale, T., Balmaseda, M.A., Balsamo, G., Buizza, R., Ferranti, L., Magnusson, L., Mogensen, K., Palmer, T., Vitart, F., 2011. The new ECMWF seasonal forecast system (System 4). Tech. Memo, Reading, UK.

Ochoa-Rivera, J.C., 2008. Prospecting droughts with stochastic artificial neural networks. J. Hydrol. 352, 174-180. doi:10.1016/j.jhydrol.2008.01.006

Ochoa-Rivera, J.C., 2002. Modelo Estocástico de Redes Neuronales para la Síntesis de Caudales Aplicados a la Gestión Probabilística de Sequías. Tesis Doctoral, Universitat Politècnica de València, Valencia, España, $226 \mathrm{pp}$.

Ortega-Gómez, T., Pérez-Martín, M.A., Estrela, T., 2018. Improvement of the drought indicators system in the Júcar River Basin, Spain. Sci. Total Environ. 610-611, 276-290. doi:10.1016/j.scitotenv.2017.07.250

Palop-Donat, C., Paredes-Arquiola, J., Andreu, J., 2020. Optimization of the Scarcity State Indicator in the Jucar river basin. Rev. Ing. del Agua 24(2), 129-140.

Paredes-Arquiola, J., 2021. Manual técnico del modelo RREA: Respuesta Rápida del Estado Ambiental de las masas de agua superficiales continentales, Universitat Politècnica de València, Valencia, España. https://aquatool.webs.upv.es/files/manuales/rrea/ManualT\%C3\%A9c nicoModeloRREA_V3.pdf.

Paredes-Arquiola, J., Solera, A., Andreu, J., Lerma, N., 2012. Manual técnico de la herramienta EVALHID para la evaluación de recursos hídricos, Universitat Politècnica de València, Valencia, España. 
Pedro-Monzonís, M., Solera, A., Ferrer, J., Estrela, T., Paredes-Arquiola, J., 2015. A review of water scarcity and drought indexes in water resources planning and management. J. Hydrol. 527, 482-493. doi:10.1016/j.jhydrol.2015.05.003

Pellicer-Martínez, F., Martínez-Paz, J.M., 2016. The Water Footprint as an indicator of environmental sustainability in water use at the river basin level. Sci. Total Environ. 571, 561-574. doi:10.1016/j.scitotenv.2016.07.022

Pérez-Martín, M., 2005. Modelo distribuido de simulación del ciclo hidrológico con calidad de aguas integrado en sistemas de información geográfica para grandes cuencas. Aportación al análisis de presiones e impactos de la Directiva Marco Europea del Agua. Tesis Doctoral, Universitat Politècnica de València, Valencia, España.

Pérez-Martín, M., Thurston, W., Estrela, T., del Amo, P., 2013. Cambio en las series hidrológicas de los últimos 30 años y sus causas. El efecto 80 , in: III Jornadas de Ingeniería Del Agua (JIA 2013). La Protección Contra Los Riesgos Hídricos. Valencia, Spain, pp. 527-534.

R Core Team, 2020. R: A language and environment for statistical computing. R Foundation for Statistical Computing, Vienna, Austria.

Rocha, J., Carvalho-Santos, C., Diogo, P., Beça, P., Keizer, J.J., Nunes, J.P., 2020. Impacts of climate change on reservoir water availability, quality and irrigation needs in a water scarce Mediterranean region (southern Portugal). Sci. Total Environ. 736. doi:10.1016/j.scitotenv.2020.139477

Rojas, R., 1996. Neural Networks: A systematic Introduction. Springer, Berlin, Germany.

Salas, J.D., Delleur, J.W., Yevjevich, V.M., Lane, W.L., 1980. Applied Modeling of Hydrologic Time Series. Water Resour. Publ. Littleton, Color. USA.

Sánchez-Quispe, S., Andreu, J., Solera, A., 2001. Gestión de Recursos Hídricos con Decisiones Basadas en Estimación del Riesgo. Universitat Politècnica de València, Valencia, España. 
Seager, R., Burgman, R., Kushnir, Y., Clement, A., Cook, E., Naik, N., Miller, J., 2008. Tropical pacific forcing of North American medieval megadroughts: Testing the concept with an atmosphere model forced by coral-reconstructed SSTs. J. Clim. 21, 6175-6190. doi:10.1175/2008JCLI2170.1

Serpa, D., Nunes, J.P., Keizer, J.J., Abrantes, N., 2017. Impacts of climate and land use changes on the water quality of a small Mediterranean catchment with intensive viticulture. Environ. Pollut. 224, 454-465. doi:10.1016/j.envpol.2017.02.026

Shrestha, S., Bhatta, B., Shrestha, M., Shrestha, P.K., 2018. Integrated assessment of the climate and landuse change impact on hydrology and water quality in the Songkhram River Basin, Thailand. Sci. Total Environ. 643, 1610-1622. doi:10.1016/j.scitotenv.2018.06.306

Stagl, J.C., Hattermann, F.F., 2016. Impacts of Climate Change on Riverine Ecosystems: Alterations of Ecologically Relevant Flow Dynamics in the Danube River and Its Major Tributaries. Water 8 (12), 566. doi:10.3390/w8120566

Stagl, J.C., Hattermann, F.F., 2015. Impacts of climate change on the hydrological regime of the danube river and its tributaries using an ensemble of climate scenarios. Water 7 (11), 6139-6172. doi:10.3390/w8120566

Suárez-Almiñana, S., Andreu, J., Solera, A., Madrigal, J., In press. Integrating seasonal forecasts into real-time drought management: Júcar River Basin case study. J. Hydrol.

Suárez-Almiñana, S., Paredes-Arquiola, J., Andreu, J., Solera, A., 2021. Efecto del cambio climático en la calidad del agua de la Cuenca del Júcar. Ing. del agua 25, 215-235. doi:10.4995/la.2021.14644

Suárez-Almiñana, S., Pedro-Monzonís, M., Paredes-Arquiola, J., Andreu, J., Solera, A., 2017. Linking Pan-European data to the local scale for decision making for global change and water scarcity within water resources planning and management. Sci. Total Environ. 603-604, 126-139. doi:10.1016/j.scitotenv.2017.05.259 
Suárez-Almiñana, S., Solera, A., Andreu, J., García-Romero, L., 2020a. Análisis de incertidumbre de las proyecciones climáticas en relación a las aportaciones históricas en la Cuenca del Júcar. Ing. del agua 24, 89. doi:10.4995/ia.2020.12149

Suárez-Almiñana, S., Solera, A., Madrigal, J., Andreu, J., Paredes-arquiola, J., 2020b. Risk assessment in water resources planning under climate change at the Júcar River Basin. Hydrol. Earth Syst. Sci. 24, 5297-5315. doi:https://doi.org/10.5194/hess-24-5297-2020

Teutschbein, C., Seibert, J., 2012. Bias correction of regional climate model simulations for hydrological climate-change impact studies: Review and evaluation of different methods. J. Hydrol. 456-457, 12-29. doi:10.1016/j.jhydrol.2012.05.052

Thompson, V., Dunstone, N.J., Scaife, A.A., Smith, D.M., Slingo, J.M., Brown, S., Belcher, S.E., 2017. High risk of unprecedented UK rainfall in the current climate. Nat. Commun. 8, 1-6. doi:10.1038/s41467-01700275-3

Trewin, B.C., 2007. Función de las normales climatológicas en un clima cambiante. Edited by $\mathrm{O}$. Baddour and $\mathrm{H}$. Kontongomde. Organización Meteorológica Mundial. Vol. 43. Ginebra.

van den Hurk, B., Hewitt, C., Jacob, D., Bessembinder, J., Doblas-Reyes, F., Döscher, R., 2018. The match between climate services demands and Earth System Models supplies. Clim. Serv. 12, 59-63. doi:10.1016/j.cliser.2018.11.002

van den Hurk, B., Bouwer, L.M., Buontempo, C., Döscher, R., Ercin, E., Hananel, C., Hunink, J.E., Kjellström, E., Klein, B., Manez, M., Pappenberger, F., Pouget, L., Ramos, M.H., Ward, P.J., Weerts, A.H., Wijngaard, J.B., 2016. Improving predictions and management of hydrological extremes through climate services. Clim. Serv. 1, 6-11. doi:10.1016/j.cliser.2016.01.001

Wanders, N., Thober, S., Kumar, R., Pan, M., Sheffield, J., Samaniego, L., Wood, E.F., 2019. Development and evaluation of a pan-European multimodel seasonal hydrological forecasting system. J. Hydrometeorol. 20, 99-115. doi:10.1175/JHM-D-18-0040.1 
Zamo, M., Naveau, P., 2018. Estimation of the Continuous Ranked Probability Score with Limited Information and Applications to Ensemble Weather Forecasts. Math. Geosci. 50, 209-234. doi:10.1007/s11004-017-9709-7 